\title{
The Mitchell Site (41BW4): An Ancestral Caddo Settlement and Cemetery on McKinney Bayou, Bowie County, Texas
}

Timothy K. Perttula

Heritage Research Center, Stephen F. Austin State University

Follow this and additional works at: https://scholarworks.sfasu.edu/ita

Part of the American Material Culture Commons, Archaeological Anthropology Commons, Environmental Studies Commons, Other American Studies Commons, Other Arts and Humanities Commons, Other History of Art, Architecture, and Archaeology Commons, and the United States History Commons

Tell us how this article helped you.

This Article is brought to you for free and open access by the Center for Regional Heritage Research at SFA ScholarWorks. It has been accepted for inclusion in Index of Texas Archaeology: Open Access Gray Literature from the Lone Star State by an authorized editor of SFA ScholarWorks. For more information, please contact cdsscholarworks@sfasu.edu. 


\section{The Mitchell Site (41BW4): An Ancestral Caddo Settlement and Cemetery on McKinney Bayou, Bowie County, Texas}

\section{Creative Commons License}

\section{(c) (1) \&}

This work is licensed under a Creative Commons Attribution-NonCommercial 4.0 International License 


\title{
The Mitchell Site (41BW4): An Ancestral Caddo Settlement and Cemetery on McKinney Bayou, Bowie County, Texas
}

\author{
Timothy K. Perttula
}

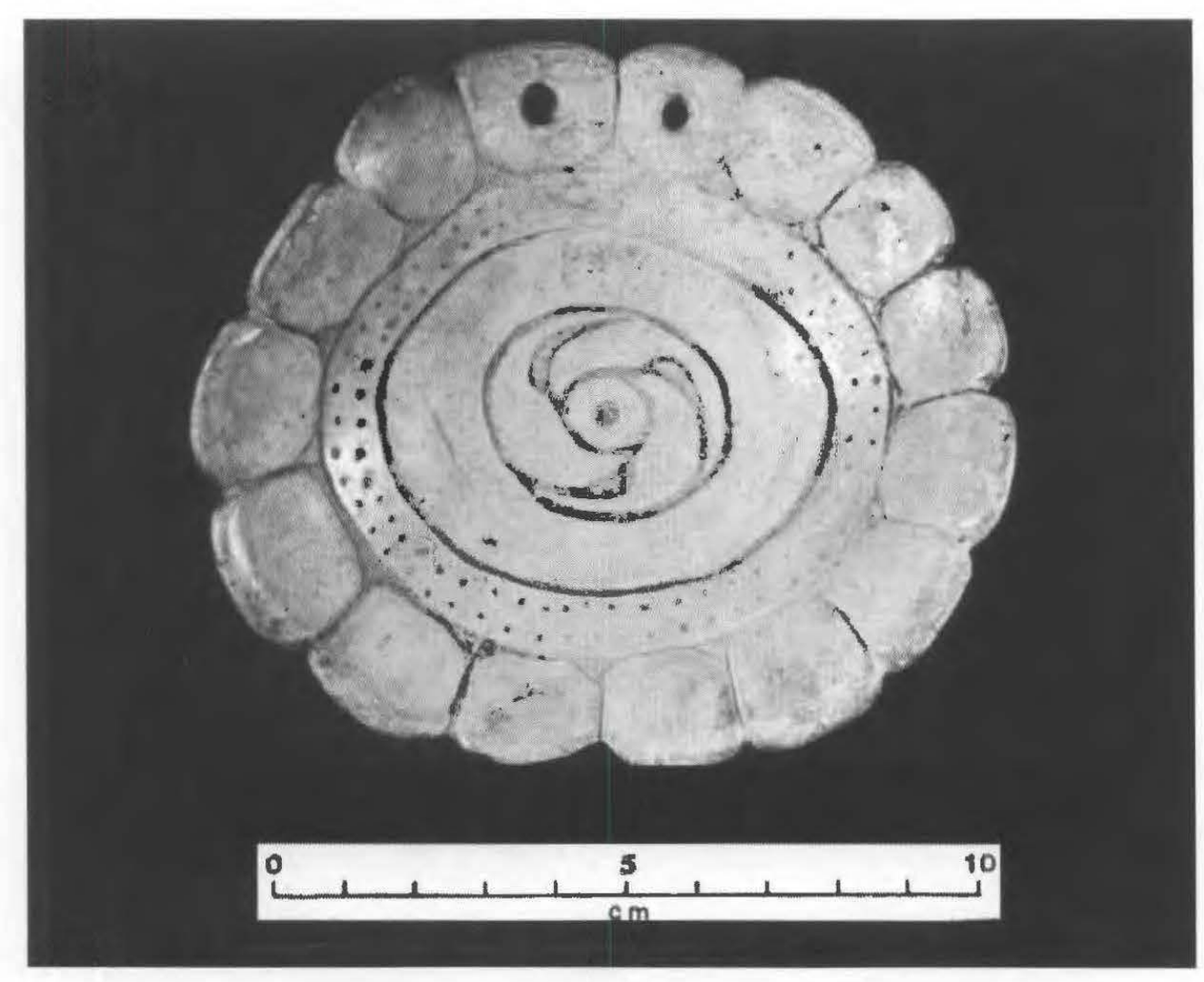

Special Publication No. 32

Friends of Northeast Texas Archaeology 


\title{
Distribution, Bo Nelson, 344 CR 4154 \\ Pittsburg, Texas 75686 \\ RBoNelson@aol.com
}

\author{
Cover art: \\ Engraved marine shell gorget (Figure 73)
}

Copyright (C) 2014, Friends of Northeast Texas Archaeology (Austin and Pittsburg) 


\section{Table of Contents}

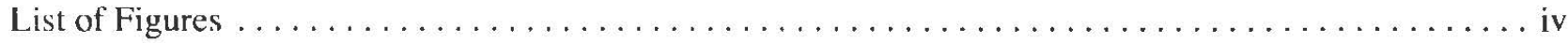

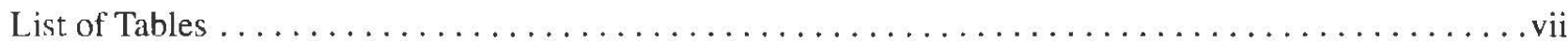

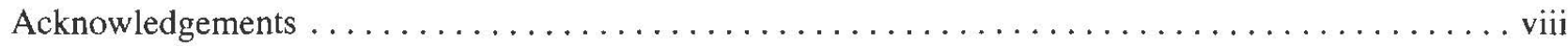

Chapter I, Introduction, Site Setting, and Cultural Context $\ldots \ldots \ldots \ldots \ldots \ldots \ldots \ldots \ldots \ldots \ldots \ldots$

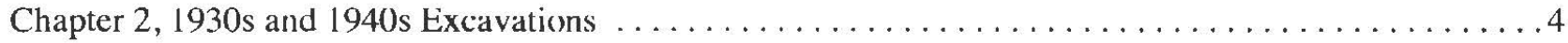

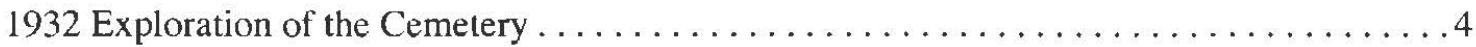

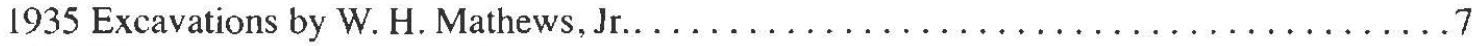

1936 Work by Martin and Mathews. . . . . . . . . . . . . . . . . . 9

1938-1939 WPA Excavations at the Paul Mitchell Site $\ldots \ldots \ldots \ldots \ldots \ldots \ldots \ldots \ldots$

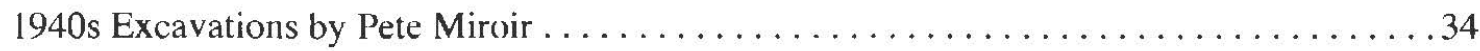

1996 Archaeological Investigations . . . . . . . . . . . . . . . . . . . . . .

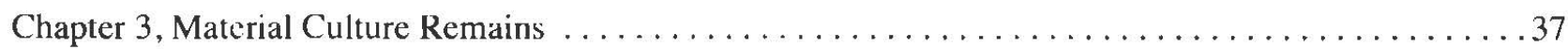

Ceramic Vessels . . . . . . . . . . . . . . . . . . . . . . . . . . . 37

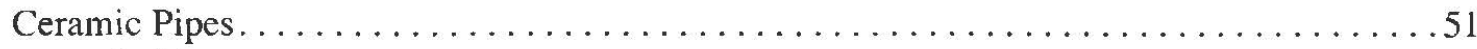

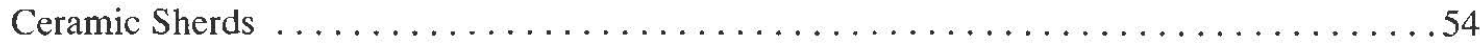

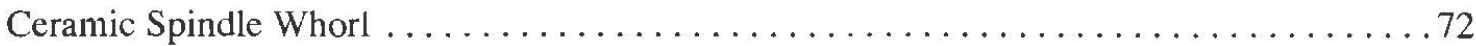

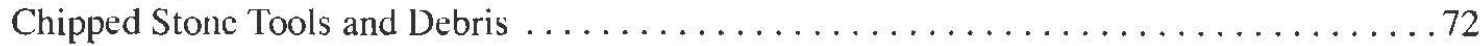

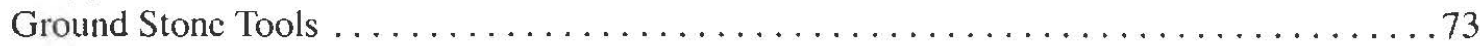

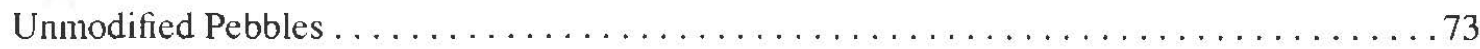

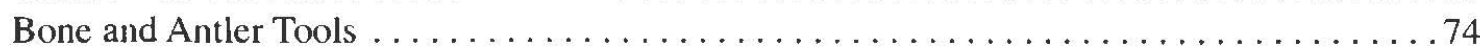

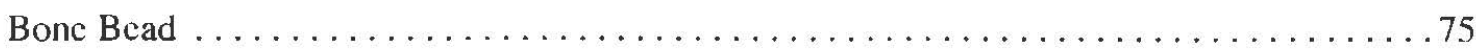

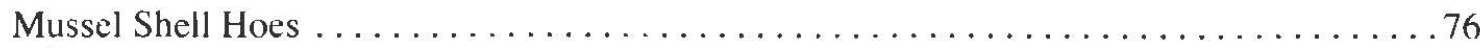

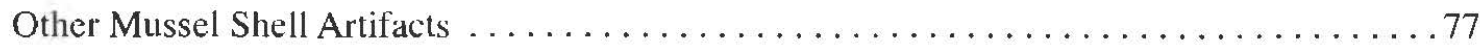

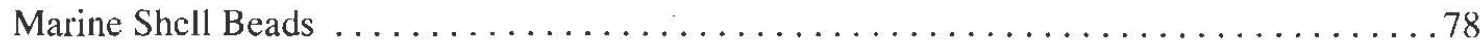

Marine Shell Gorgets . . . . . . . . . . . . . . . . . . . . . . . 78

Perforated Human Teeth. . . . . . . . . . . . . . . . . . . . . . . 80

Animal Bones . . . . . . . . . . . . . . . . . . . . . . . . . . . 80

Chapter 4 , Age of the Site and Cultural Affiliation $\ldots \ldots \ldots \ldots \ldots \ldots \ldots \ldots \ldots \ldots \ldots \ldots \ldots \ldots \ldots \ldots$

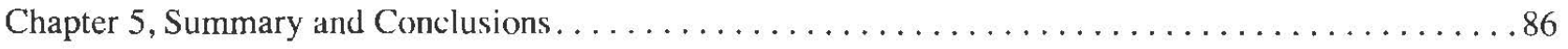

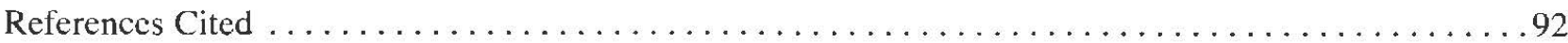




\section{List of Figures}

1. The Mitchell site and other Nasoni Caddo sites on the Red River in Bowie County, Texas......... 1

2. Excavations at the Paul Mitchell site by Jackson 1931, 1932, Mathews 1935,

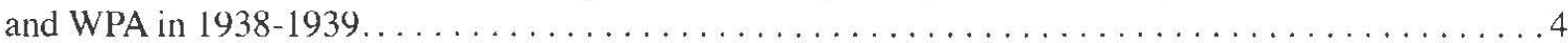

3. Haley Engraved compound bowl from Burial K-2 at the Mitchell site $\ldots \ldots \ldots \ldots \ldots \ldots \ldots$

4. Map of 1935 excavations by W. H. Mathews, Jr. at the Mitchell site cemetery . . . . . . . . 6

5. Other funerary offerings from the Caddo burials excavated by W. H. Mathews in 1935:

a, conch shell beads, Burial 10; b, conch shell beads, Burial 14; c, elbow pipe, Burial $12 \ldots \ldots .8$

6. Burials No. 1 and No. 2 excavated in 1936 at the Paul Mitchell site $\ldots \ldots \ldots \ldots \ldots \ldots \ldots \ldots$

7. WPA excavations at the Mitchell site, and the area excavated by Pete Miroir in $1946 \ldots \ldots \ldots \ldots 11$

8. Ceramic vessels from Burial 3: a, Barkman Engraved carinated bowl (6-2-35); b, engraved bowl with rim peaks (6-2-36). Vessel images courtesy of the Texas Archeological Research

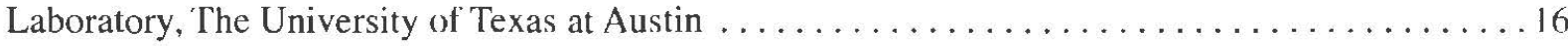

9. Burial 4: a, plan map; b, noded bowl (6-2-38). Vessel image courtesy of the Texas Archeological

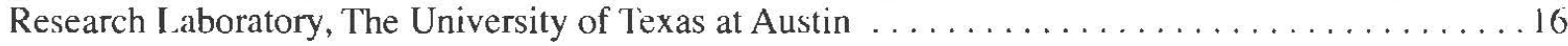

10. Burial 12: a, plan map; b, engraved bottle (6-2-39). Vessel image courtesy of the Texas Archeological Research Laboratory. The University of Texas at Austin . . . . . . . . . . . 17

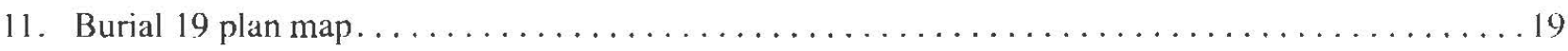

12. Burial 28 at the Paul Mitchell site . . . . . . . . . . . . . . . . . . . . . . . 19

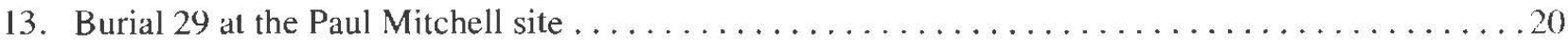

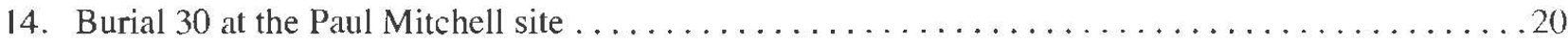

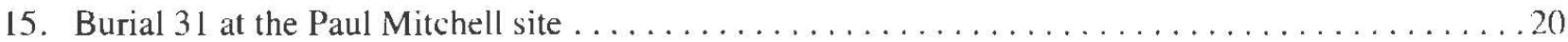

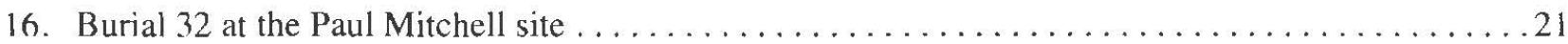

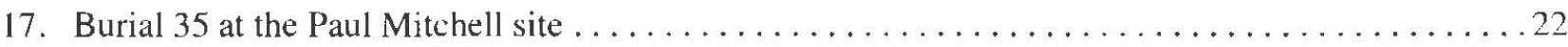

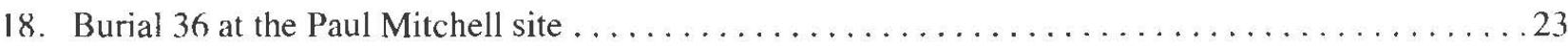

19. Appliqued jar vessel section (6-2-171) from Burial 37 at the Mitchell site. Vessel image courtesy of the Texas Archeological Research Laboratory, The University of Texas at Austin . . . . 223

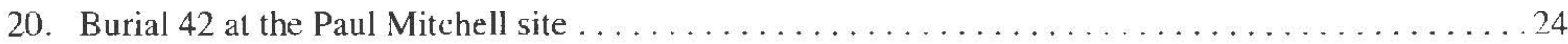

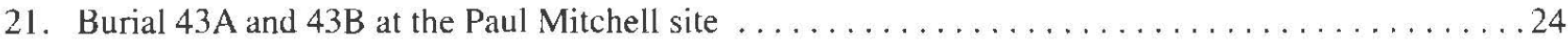

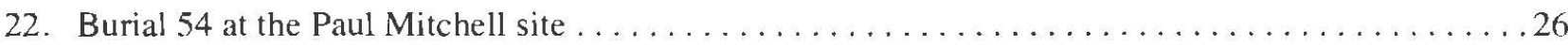

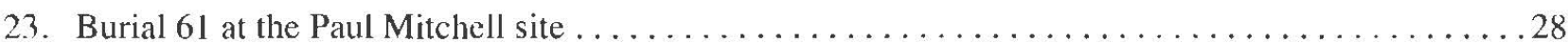

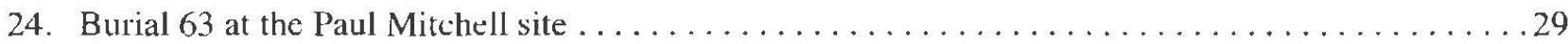

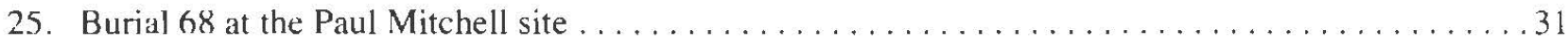

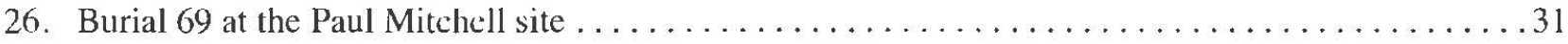




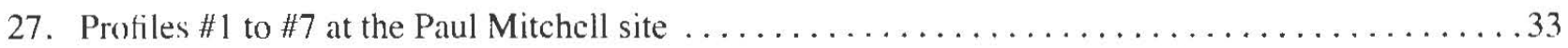

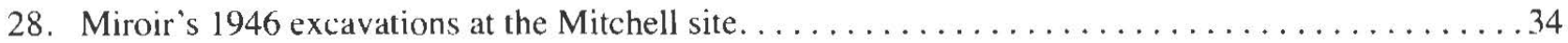

29. Ceramic ear spool from Miroir's Burial 1 at the Paul Mitchell site $\ldots \ldots \ldots \ldots \ldots \ldots \ldots \ldots$

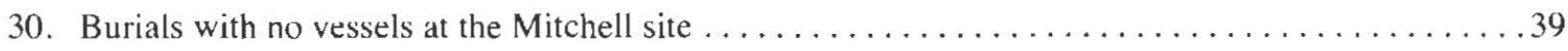

31. Burials with ca. A.D. $1200-1400$ vessels in the Mitchell site cemetery $\ldots \ldots \ldots \ldots \ldots \ldots \ldots \ldots$

32. Haley Engraved bottle from Burial 6 excavated by Mathews at the Mitchell cemetery ........41

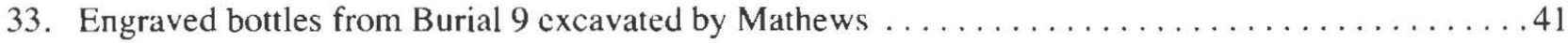

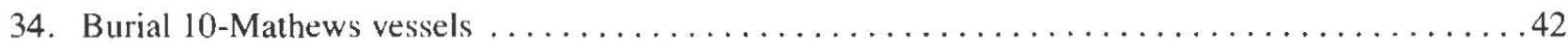

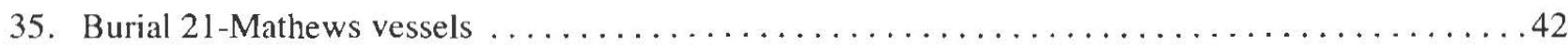

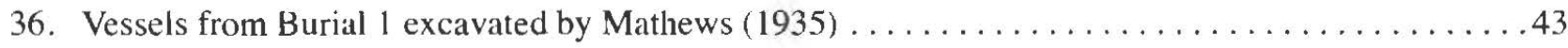

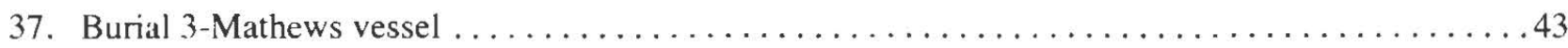

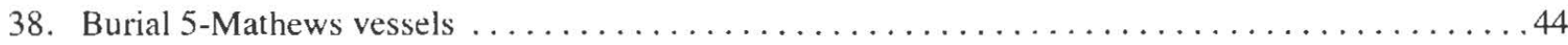

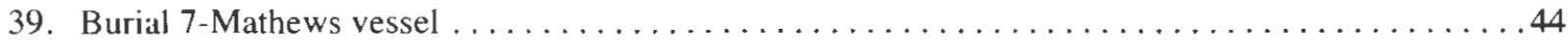

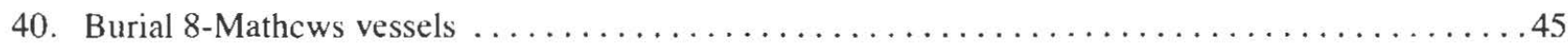

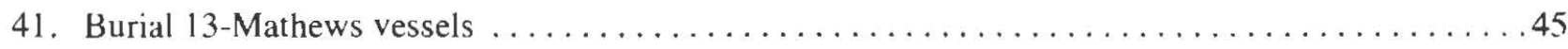

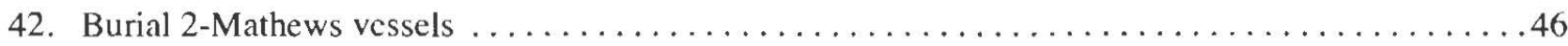

43. Vessels from Burials 1-3 excavated by Pete Miroir in 1946 in the Mitchell site cemetery:

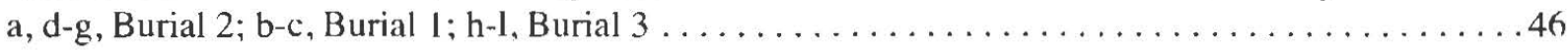

44. Distribution of burials with Barkman Engraved and Pease Brushed-Incised vessels . . . . . . . . 47

45. Vessels from Burial 11 excavated by Mathews at the Mitchell site cemetery $\ldots \ldots \ldots \ldots \ldots \ldots 48$

46. Vessels from Burial 14 excavated by Mathews at the Mitchell site cemetery . . . . . . . . . . 48

47. Vessels from Burial 15 excavated by Mathews at the Mitchell site $\ldots \ldots \ldots \ldots \ldots \ldots \ldots \ldots \ldots 49$

48. Vessels from Burial 20 excavated by Mathews at the Mitchell site $\ldots \ldots \ldots \ldots \ldots \ldots \ldots \ldots$

49. Vessels from Burial 17 excavated at the Mitchell site cemetery by Mathews . . . . . . . . . 50

50. Vessels from Burial 19 excavated by Mathews at the Mitchell site $\ldots \ldots \ldots \ldots \ldots \ldots \ldots \ldots$

51. Vessels from Burial 18 excavated by Mathews at the Mitchell site $\ldots \ldots \ldots \ldots \ldots \ldots \ldots \ldots \ldots$

52. Distribution of 'Texarkana phase burials in the Mitchell site cemetery $\ldots \ldots \ldots \ldots \ldots \ldots \ldots \ldots$

53. Vessels from Burial 12 excavated by Mathews in the Mitchell site ecmetery. . . . . . . . . .53

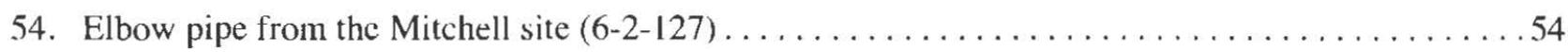

55. Elbow pipes from Mitchell site burials: a, Burial 3; b, Burial 19; c, Burial 28. . . . . . . . 55

56. Long-stemmed Red River pipes from the Mitchell site: a, Burial 66; b, Burial $69 \ldots \ldots \ldots \ldots .56$

57. Appliqued, pinched, and trailed-punctated body sherds: a, appliqued; b, pinched; c, trailed-punctated (Foster Trailed-Incised). Provenience: a, General; b, Square 5-R-2,

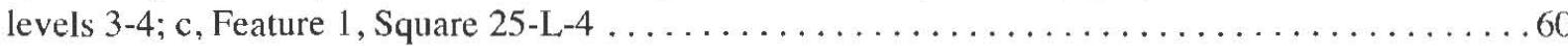


58. Incised rim and body sherds: a-c, rims; d-f, body and lower rim-body sherds. Provenience: a, Square 40-L-1, level 3; b; Square 30-L-3, layer 3; c, Square 5-L-3, layer 3; d, east side of cemetery, midden; e, east side of cemetery; $f$, Test Pit east of cemetery .

59. Incised-punctated rim and lower rim-body sherds in the Mitchell site utility wares. Provenience: a, pre-WPA surface collection; b-d east side of cemetery, midden;

e, Burial 50 fill; $f$, east side of cemetery, midden; $g$, pre-WPA surface collection

60. Decorative elements on an incised-punctated vessel rim and body section. Provenience:

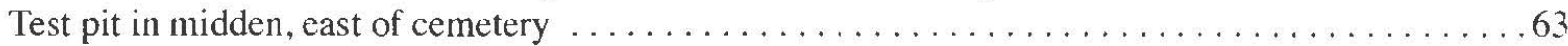

61. Incised-punctated body sherds. Provenience: a, pre-WTA surface collection; b, east side of cemetery, midden; c-e, east side of cemetery; $f$, Test Pit cast of cemetery; g. Square 10-R-1; h, Burial 45 fill; i, east side of cemetery; j, Burial 66 ? fill . . . . . . . . . . 65

62. Barkman Engraved and Handy Engraved rim and body sherds. Provenience: a, Feature 2, 55-L-1; b-c, Feature 1, 25-L-4; d-e, Feature 2, 60-L-3; f, east side of cemetery, midden;

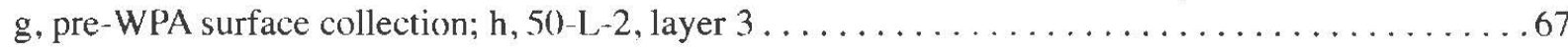

63. Simms Engraved decorative elements. Provenience: a, Feature 2, 50-L-3; b. Burial 66? fill; c-e, pre-WPA surface collection

(it. Other engraved and trailed decorative elements in the Mitchell site fine wares. Provenience: a, 40-L-2, layer 2; b, east side of cemetery, midden; c, 65-L-4, layer 3; d, Burial 51 fill; e, east side of cemetery, midden; f, General . . . . . . . . . . . . . . 68

65. Engraved decorative elements on bottle sherds. Provenınce: a, Burial 13 fill; b-d, unidentified provenience; e, east side of cemetery, midden; $\mathrm{f}$. Burial 17 fill; $\mathrm{g}$, surface in pothunter area; h, Feature 2, 55-L-2; i, Feature 2, 60-L-3; j, Feature 1,

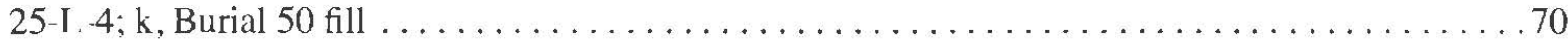

66. Ceramic spindle whorl from the midden at the Mitchell site $\ldots \ldots \ldots \ldots \ldots \ldots \ldots \ldots \ldots \ldots$

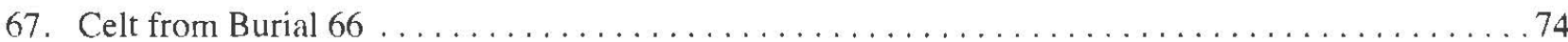

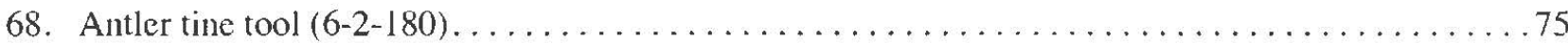

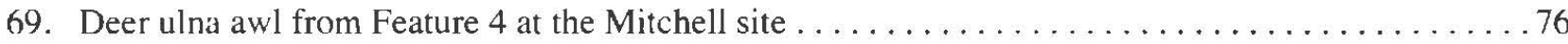

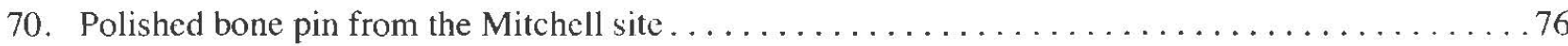

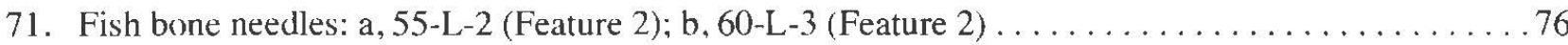

72. Mussel shell hoes from the Mitchell site: a, northwest side of the cemetery (6-2-125); b, east side of cemetery (6-2-172, Burial 48); c-d, 6-2-124 (midden); c, Burial $12 \ldots \ldots \ldots \ldots .77$

73. Marine shell gorget from Burial 19 at the Mitchell site $\ldots \ldots \ldots \ldots \ldots \ldots \ldots \ldots \ldots \ldots$

74. Engraved cruciform style marine shell gorget from the Mitchell site $\ldots \ldots \ldots \ldots \ldots \ldots \ldots \ldots$

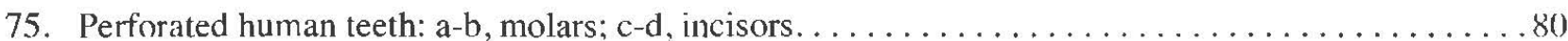

76. Earlier and Main Late periods of cemetery use at the Mitchell site $\ldots \ldots \ldots \ldots \ldots \ldots \ldots \ldots . .82$

77. Important Middle Caddo sites, major Red River Caddo centers occupied during the Middle Caddo period, and defined Middlc Caddo period phax $4 \ldots \ldots \ldots \ldots \ldots \ldots \ldots \ldots 4$

78. Late Caddo period phases in East Texas and immediately surrounding areas. . . . . . . . . 85 


\section{List of Tables}

1. Burials 1-21 excavated and/or documented by W. H. Mathews, Jr. at the Mitchell site . . . . . . 7

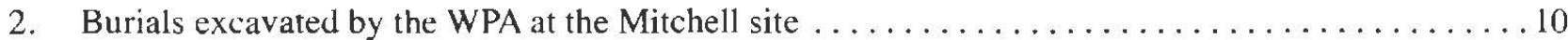

3. Use of temper in ceramic sherds from non-burial contexts at the Mitchell site $\ldots \ldots \ldots \ldots \ldots . .56$

4. Utility ware and fine ware sherds in the Mitchell site non-burial ceramic assemblage . . . . . . .57

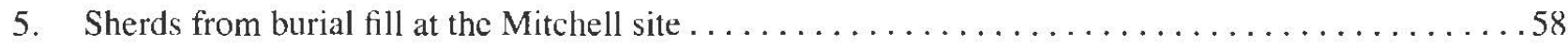

6. Decorative elements on incised sherds in the Mitchell site utility wares $\ldots \ldots \ldots \ldots \ldots \ldots \ldots 61$

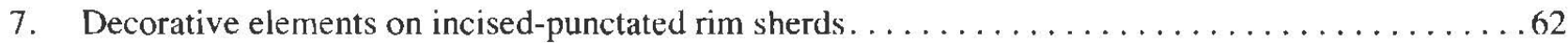

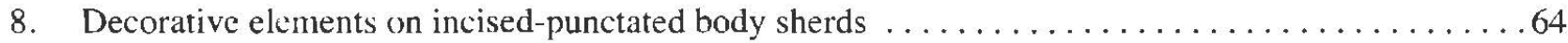

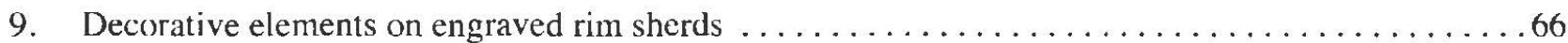

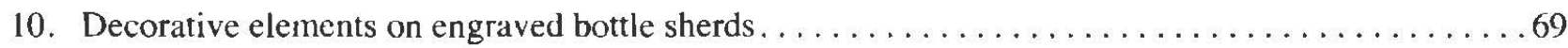




\section{Acknowledgments}

I want to thank Laura Nightengale at the Texas Archeological Research Laboratory, The University of Texas at Austin for her helping in many ways to facilitate this study of the Mitchell site records and collections. Robert Z. SeIden Jr. calibrated the one radiocarbon date obtained for the site as part of this $1 j$ ect. Lance Trask performed yeoman service in preparing the many figures in this publication. 


\section{CHAPTER 1, INTRODUCTION, SITE SETTING, AND CULTURAL CONTEXT}

The Paul Mitchell site (41BW4) is an ancestral Caddo habitation site and cemetery in the larger ancestral and historic occupation of the Upper Nasoni Village on the Red River in Bowie County, in the northeastern corner of the present state of Texas. Extensive excavations were conducted at the site in the 1930s by both professional and avocational archaeologists, and in the 1940s by an avocational archaeologist, but the findings from these investigations have never heen fully analyzed or reported to date (Creel 1996), although several bioarchaeological studies have been published concerning the Mitchell site human remains (Lee 1997; Lippert 1997; Wilson 1997; see also Derrick and Wilson 1997). This monograph represents a renewed examination of the records and collections from the various archaeological investigations in the cemetery at the Mitchell site, and the findings concerning the use of the site contribute to a fuller understanding of the history and prehistory of the Caddo peoples that lived at the Mitchell site and other settlements in the Red River valley of Northeast Texas.

The Paul Mitchell site is located in the McKinney Bayou floodplain about 2 miles from the current channel of the Red River to the north. The site is part of a large Upper Nasoni village believed to have extended several miles along the Red River, likely encompassing contemporaneous sites such as Eli Moores (41BW2), Hatchel (41BW3), Hargrove Moores (41BW39), and Horace Cabe (41BW14) (Figure 1). The Hatchel Mound is about $1.6 \mathrm{~km}$ north of the Mitchell site.

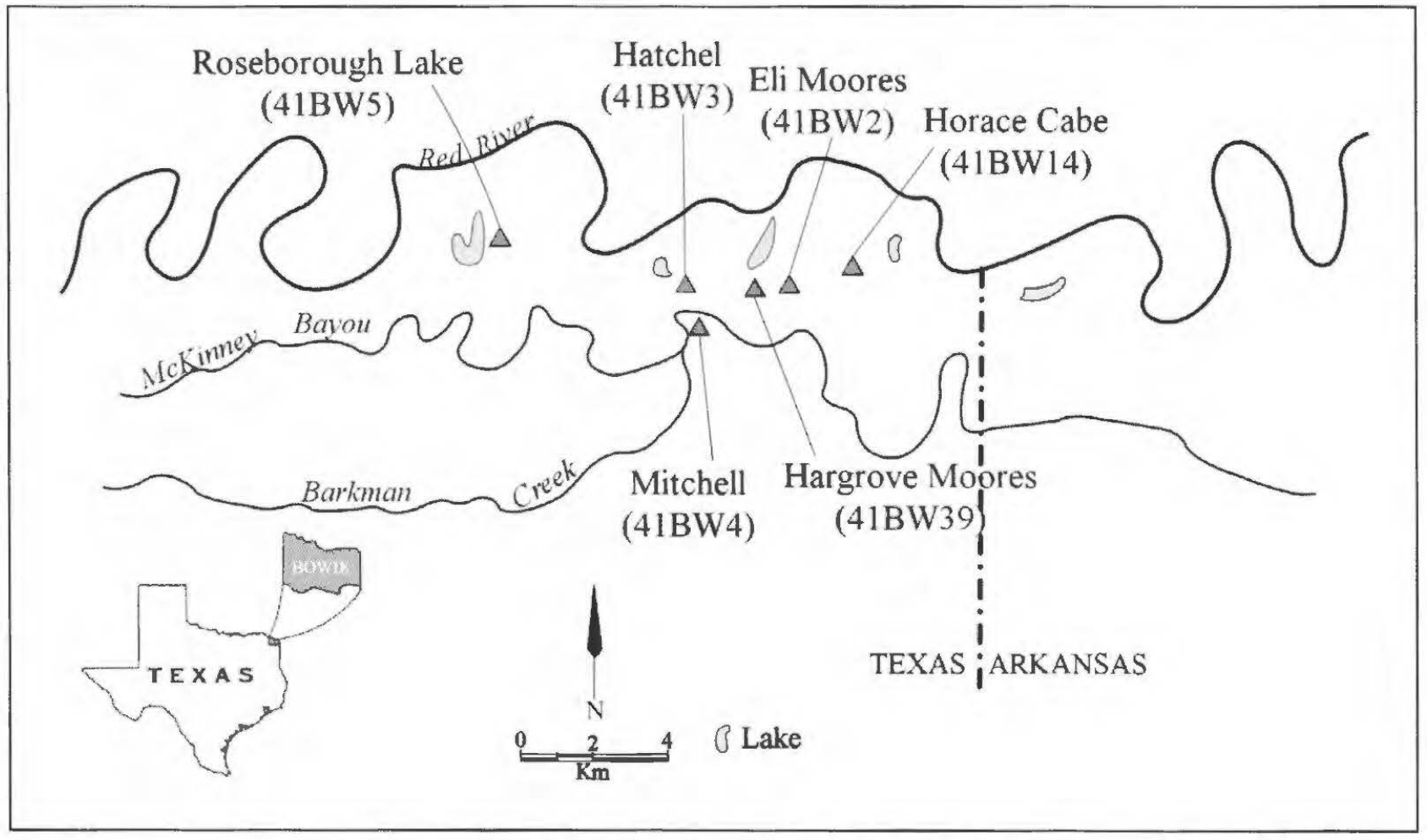

Figure 1. The Mitchell site and other Nasoni Caddo sites on the Red River in Bowie County, Texas.

In ancestral times, beginning in the 9th and 10th centuries A.D., long before Europeans came to what became Texas and the United States, the Caddo Indians had become mound builders, expert traders and artisans, and eventually accomplished farmers, as well as the most socially complex Native American communities living between the Mississippi River and the ancestral Puebloan peoples of the American 
Southwest. When Europeans came among the Caddo in the late 17th century, they relied on the good will of the Caddo to explore what became Texas, as well as the diplomatic and economic skills of the people. Following disease, depredations, and territorial dispossession at the hands of French, Spanish, English, and American speculators, mercenaries, priests, traders, and land developers, by 1835 . the Caddo's fate in Texas became clear, and the policies of the Republic of Texas and the United States between them led to their forced exodus from Texas to Indian Territory in 1859. The Caddo, now the Caddo Nation of Oklahoma, live to this day in their new western Oklahoma home.

During the more than 2400 years that the Caddo peoples, and their Woodland period (ca. 500 B.C. to A.D. 800/850) ancestors, lived in Texas, they inhabited camp sites, hamlets, villages, and civic-ceremonial mound centers over a large area of four different states, including eastern Texas, northwestern Louisiana, southwestern Arkansas, and eastern Oklahoma, centered on the Red River and its tributary streams. More specifically, the southern Caddo area is centered on the Red River and its main tributary streams, as well as the Sabine and Neches rivers in East Texas, and includes the Gulf Coastal Plain and Ouachita Mountains physiographic provinces. The northern Caddo area is centered in the Arkansas River basin in the states of Arkansas and Oklahoma, and includes parts of the adjoining Ozark Plateau. At its maximum extent, the Caddo archaeological area extends $600 \mathrm{~km}$ north to south and $300 \mathrm{~km}$ east to west, covering approximately $180,000 \mathrm{~km}^{2}$.

The Caddo archaeological record is a one-thousand year record of cultural change and continuity among a variety of closely related peoples who maintained thcir own distinctive socio-political and economic dynamic while Mississippian polities in the Southeastern United States fought and competed for power and tribute. Archaeological research on the sites and sacred places left behind by the Caddo peoples since the early 1900 s have rather convincingly demonstrated that the Caddo archaeological tradition should be understood and appreciated through its own long native history.

The Caddo archaeological and cultural tradition represents "an archaeological concept... recognizable primarily on the basis of a set of long-standing and distinctive cultural, social, and political elements that have temporal, spatial, and geographic connotations" (Perttula 1992:7). Best known for the distinctive and beautifully-made engraved ceramic vessels found on mound and habitation sites, the Caddo archaeological tradition in basic terms is charactcrizcd by dispersed but sedentary settlements of villages, hamlets, and farmsteads, the development through time of an horticultural to an agricultural economy dependent upon domesticated corn, beans, and squash, and a complex socio-political structure denoted principally by a complex network of mound centers and the differential treatment of the dead by rank or hierarchy, most notably in burial mound shaft tombs accompanied by elaborate kinds of grave goods, many of exotic origin (Brown 2010; Early 2000, 2004; Girard 2010).

Caddo archaeologists have argued that the development of Caddo cultural traditions in prehistoric times took place relatively independently of the emergence of Mississippian cultural developments in the southeastern U.S (Girard et al. 2014). Archacological research conducted over the past 40 years, in combination with the development of radiocarbon dating, has shown that the Caddo archaeological tradition began as early as about A.D. 800/900, out of an indigenous Woodland tradition of hunter-gatherer-gardener peoples. Caddo societies shared much with their Southeastern U.S. Mississippian neighbors, including the adoption of maize and the intensification of maize agricultural economies, an emphasis on monumentality (e.g., Anderson 2012), as well as in systems of social authority and ceremony (e.g., Blitz 2010: Butler and Welch 2006). Although there are clear socio-political and trade relationships with the Southeast and various Mississippian groups, the people living in the Caddo area are manifestly different in several intriguing ways. The Caddo archaeological record documents a millennium of native history among peoples who maintained their own distinctive socio-political, economic, and technological dynamic. 
The principal occupation of this part of the Red River basin in East Texas in prehistoric and early historic times (up to about A.D. 1790) was by Caddo-speaking Indian groups that lived in settled horticultural and agricultural communities. These communities were composed principally of farmsteads and small hamlets, but larger villages, as at the Hatchel, Mitchell, Eli Moores (41BW2) and Cabe (41BW14) sites (see Figure 1), were situated along the Red River bottomlands during much of the prehistoric and historic era (e.g., Story 1990; Creel 1996; Perttula 2005; Perttula et al. 1995), particularly during the Texarkana phase after ca. A.D. 1400, the latest Caddo culture in the area (Creel 1996:505). Caddo archaeological sites in the region are known to be primarily located on elevated landforms (alluvial terraces and rises, natural levees, and upland edges) adjacent to the major streams, as well as along spring-fed branches and smaller tributaries with dependable water flow. Thcy are also located in proximity to arable sandy loam soils, presumably for cultivation purposes with digging sticks and stone celts.

These Caddo groups were powerful theocratic chiefdoms that built earthen mounds (like the platform mound at the Hatchel site, see Jackson 2004) for political and religious purposes, functions, and rituals, traded extensively across the region as well as with non-Caddoan speaking groups, and developed intensive maize-producing economies by the 13 th century A.D. (Perttula et al. 2014). Due to diseases introduced by Europeans sometime after the mid-16th century, and the incursions of the Osage to obtain deer hides and Caddo slaves, by about 1790 , the Red River valley in the Texarkana area was abandoned by the Caddo groups. 


\section{CHAPTER 2, 1930S AND 1940S EXCAVATIONS}

A number of excavations were conducted at the Paul Mitchell site in the 1930s and 1940s (Figure 2), beginning with investigations by The University of Texas (UT) in 1931 and 1932; the 1931 excavations were not productive as no cultural features were identified in the work along the levee bank. Work that followed in 1932, 1935, 1936, 1938-1939, and 1946 was almost totally focused on the identification and excavation of ancestral Caddo burials from a large cemetery along McKinney Bayou.

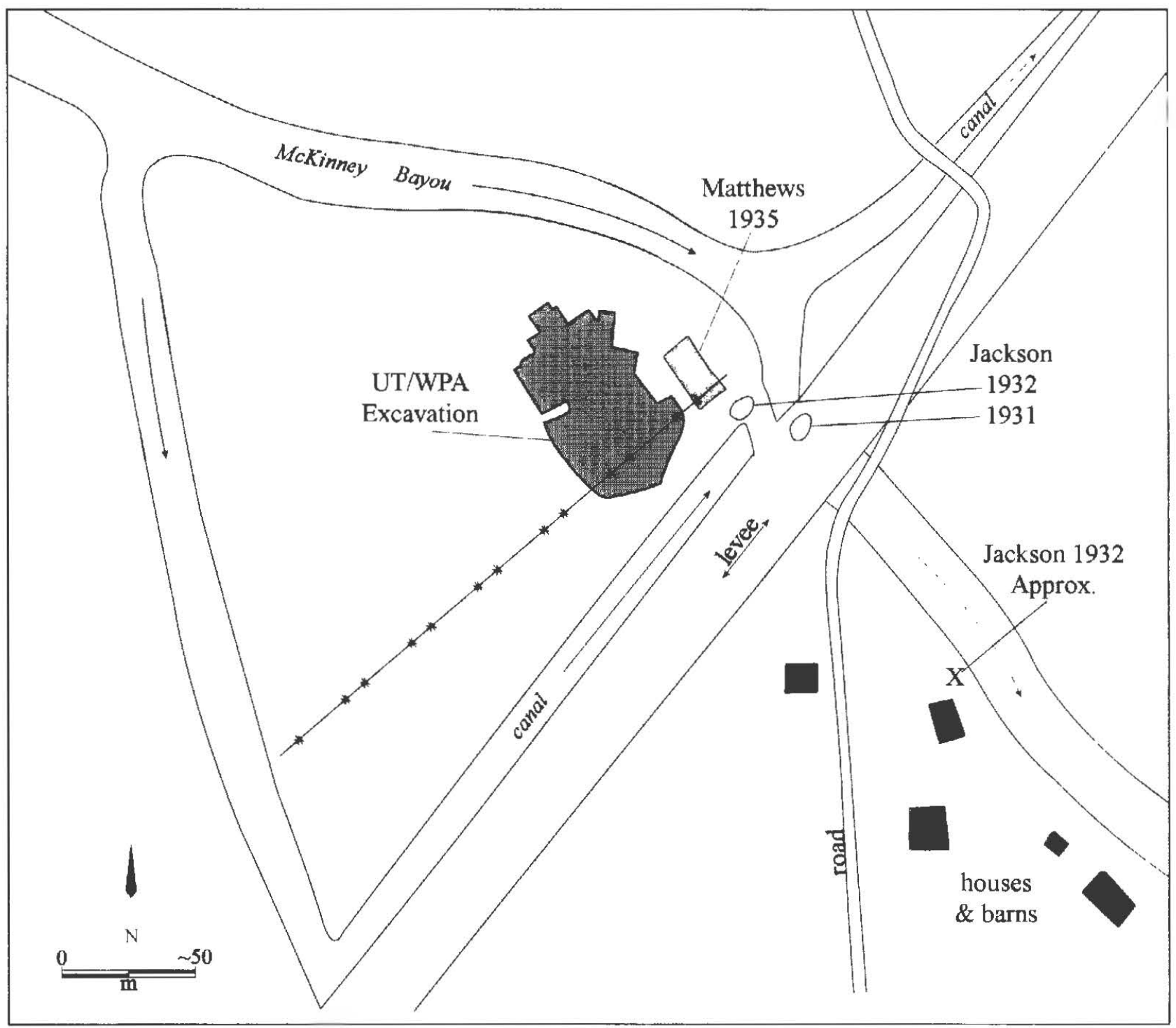

Figure 2. Excavations at the Paul Mitchell site by Jackson 1931, 1932, Mathews 1935, and WPA in 19.38-1939.

\section{Exploration of the Cemetery}

Precipitated by the discovery of American Indian human remains and funerary objects (ceramic vessels) during construction of a levee along McKinney Bayou, and 1930 digging by the son of Paul Mitchell that encountered a Caddo burial, in September 1932 University of Texas (UT) archaeologist A. T. Jackson and a crew explored an arca 24-28 ft. west of the McKinney Bayou bank (see Figure 2), in the 
Paul Mitchell family's back yard (Jackson 1932). This is some $150 \mathrm{~m}$ southeast from the Works Progress Administration (WPA) excavations to be discussed below (see Woolsey and Martin 1939:2).

During the work, four Caddo Indian burials (K-1 to K-4) were located in the Mitchell back yard, between depths of $53-91 \mathrm{~cm}$ below the ground surface. Burials $\mathrm{K}-1$ is an adult male $40-50$ years of age at death (Lee 1997:Table 2), while the other three burials were those of children or infants (Lee 1997:Table 2): 6-7 months of age for Burial K-2, 1-2 years for Burial K-3, and 3-9 months for Burial K-4 (Lee 1997:Table 2). The individual in Burial K-1 has a cranially modeled skull (tabular fronto-vertico-occiptal) (Lee 1997:Table 3).

Only a single funerary offering accompanied these burials (although since Burial K-1 had been previously dug into by Paul Mitchell's son, it is unclear if funerary offerings were removed from the grave prior to the UT excavations). This is a compound bowI with a high rim, and engraved scroll motifs on both the upper and lower rim panels (Figure 3). The diagonal hatching or tick marks on the scrolls are stylistically reminiscent of Barkman Engraved (see Suhm and Jelks 1962:Plate 4), but the decorative elements comprising the motif are not. The closest stylistic comparisons are to certain Haley Engraved vessels (Suhm and Jelks 1962:Plate 31f)

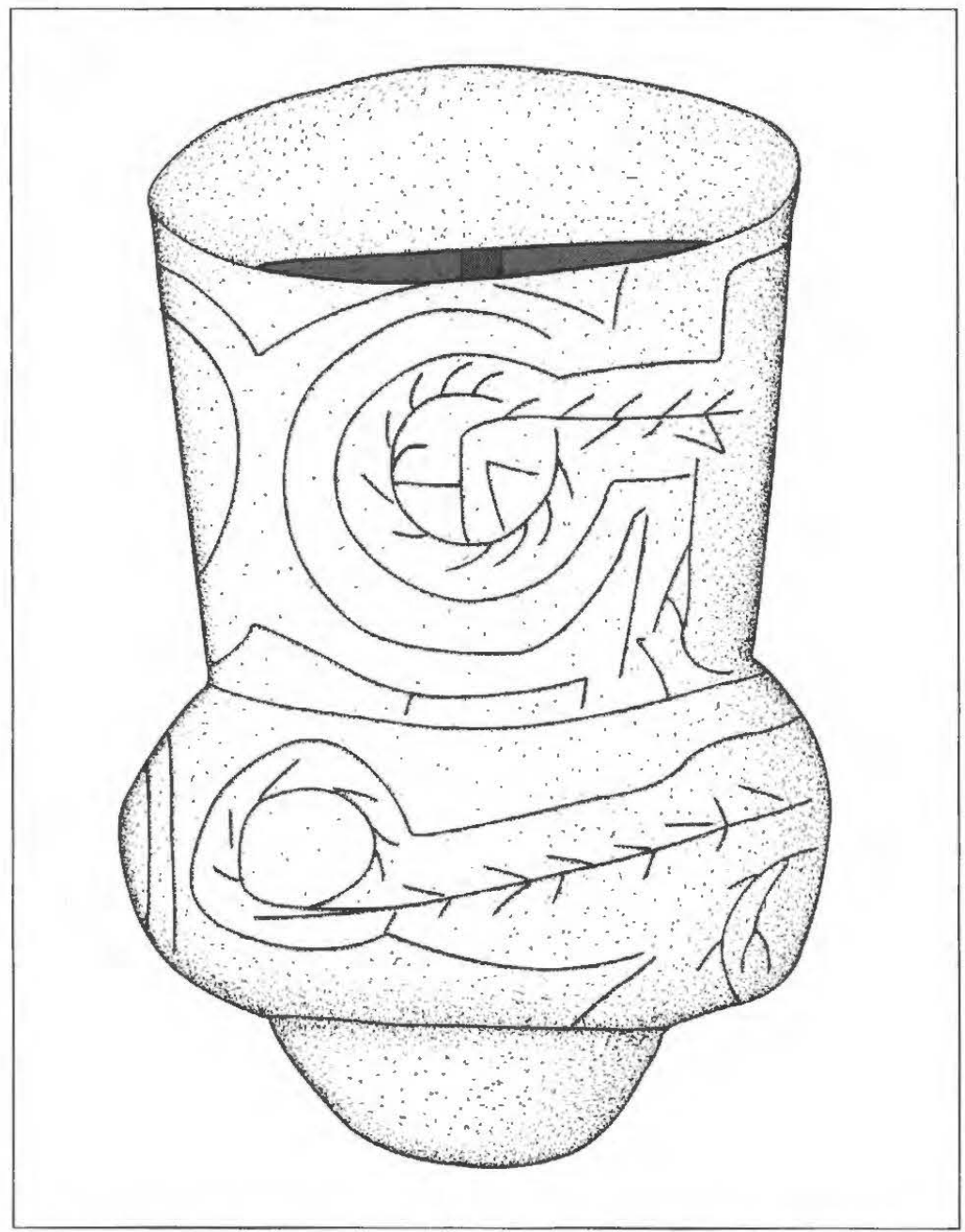

Figure 3. Haley Engraved compound bowl from Burial K-2 at the Mitchell site. 


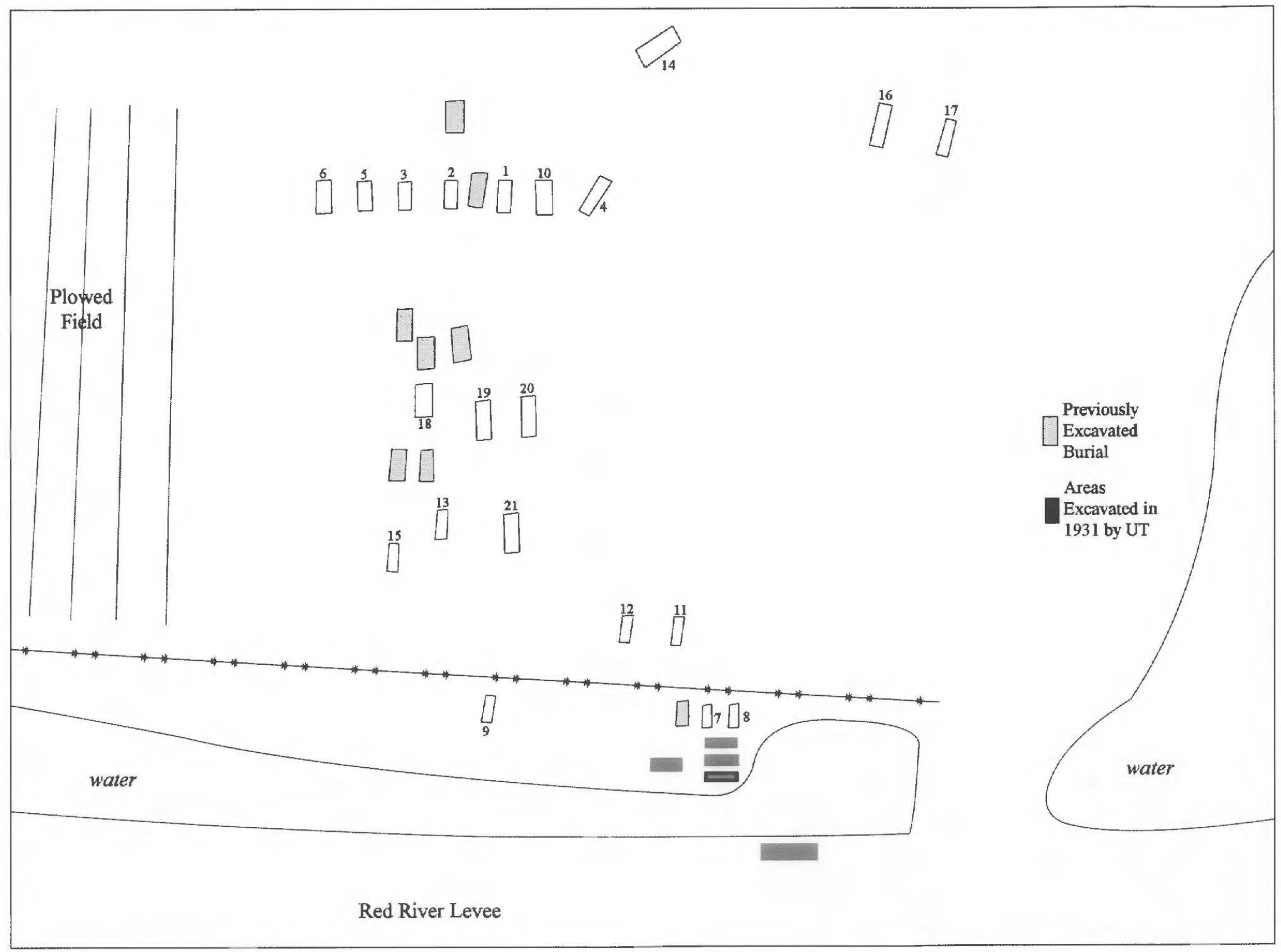

Figure 4. Map of 1935 excavations by W. H. Mathews, Jr. at the Mitchell site cemetery. 


\section{Excavations by W. H. Mathews, Jr.}

W. H. Mathews, Jr., a local avocational archaeologist, excavated between February and April 1935 a total of 15 ancestral Caddo burials at the Mitchell site, in an area just east of the later WPA cxcavations (see Figure 2). Another six burials were excavated by unspecificd others at the same time (Mathews 1935) (Figure 4), but burial plans were obtained by Mathews, along with information on the associated funerary offerings. Available information on these burials is provided in Table 1.

Table 1. Burials 1-21 excavated and/or documented by W. H. Mathews, Jr. at the Mitchell site.

\begin{tabular}{|c|c|c|c|c|}
\hline $\begin{array}{l}\text { Burial } \\
\text { No. }\end{array}$ & Position & Head orientation & $\begin{array}{r}\text { Depth } \\
(\mathrm{cm})\end{array}$ & Funerary Offerings \\
\hline 1 & Extended & Facing north & 97 & $\begin{array}{l}\text { Four ceramic vessels; one } \\
\text { vessel with yellow clay } \\
\text { pigment }\end{array}$ \\
\hline 2 & Extended & Facing north & 61 & $\begin{array}{l}\text { Three vessels; cranially } \\
\text { modificd skull }\end{array}$ \\
\hline 3 & Extended & Facing north & 71 & One carinated bowl \\
\hline 4 & Extended & Facing northwest & 36 & None \\
\hline 5 & Extended & Facing north & 104 & Three ceramic vessels \\
\hline 6 & Extended & Facing north & 104 & One ceramic bottle \\
\hline 7 & Extended & Facing north & 31 & One carinated bowl \\
\hline 8 & Extended & Facing north & 46 & Three ceramic vessels \\
\hline 9 & Extended & Facing north & 46 & $\begin{array}{l}\text { Three ceranic vessels and a } \\
\text { mussel shell holding red clay } \\
\text { pigment }\end{array}$ \\
\hline 10 & Extended & Facing north & 66 & Five ceramic vessels \\
\hline 11 & Extended & Facing north & 51 & Two ceramic vessels \\
\hline 12 & Extended & Facing north & 58 & $\begin{array}{l}\text { Three ceramic vessels and } \\
\text { one elbow pipe }\end{array}$ \\
\hline 13 & Extended & Facing north & 122 & Two ceramic vessels \\
\hline 14 & Extended & Facing northeast & 127 & $\begin{array}{l}\text { Five ceramic vessels and } 13 \\
\text { shell beads around the neck }\end{array}$ \\
\hline 15 & Extended & Facing north & 125 & Six ceramic vessels \\
\hline 16 & Extended & Facing north & 31 & One carinated bowl \\
\hline 17 & Extended & Facing south & 33 & Five ceramic vessels \\
\hline 18 & Extended & Facing north & 122 & $\begin{array}{l}\text { Three ceramic vessels and } 10 \\
\text { shell beads at the right wrist }\end{array}$ \\
\hline 19 & Extended & Facing south & 127 & Three ceramic vessels \\
\hline 20 & Extended & Facing north & 102 & $\begin{array}{l}\text { Two ceramic vessels and } 17 \\
\text { shcll beads around the neck }\end{array}$ \\
\hline 21 & Extended & Facing north & 46 & Three ceramic vessels \\
\hline
\end{tabular}

All 21 of the burials are in an extended supine position, and appear to be adults based on the size of the burial pits. In more than 80 percent of the burials, the deceased's head was facing to the north; two others were facing south, and two were facing either to the northeast or the northwest (Table 1). One deceased Caddo individual (Burial 2) clearly had a cranially modified skull. The burials were excavated 
to variable depths, but the burials placed in shallower pits are primarily situated in the southern part of the cemetery, away from McKinney Bayou (see Figure 4). The funerary offerings in the 21 burials included 59 ceramic vessels ( 2.8 vessels per burial), one ceramic elbow pipe (Figure $5 \mathrm{c}$ ), 40 conch shell beads (13.3 beads per burial among the three burials with shell beads) (Figures 5a-b), and one mussel shell that held a red clay pigment (see Table 1).

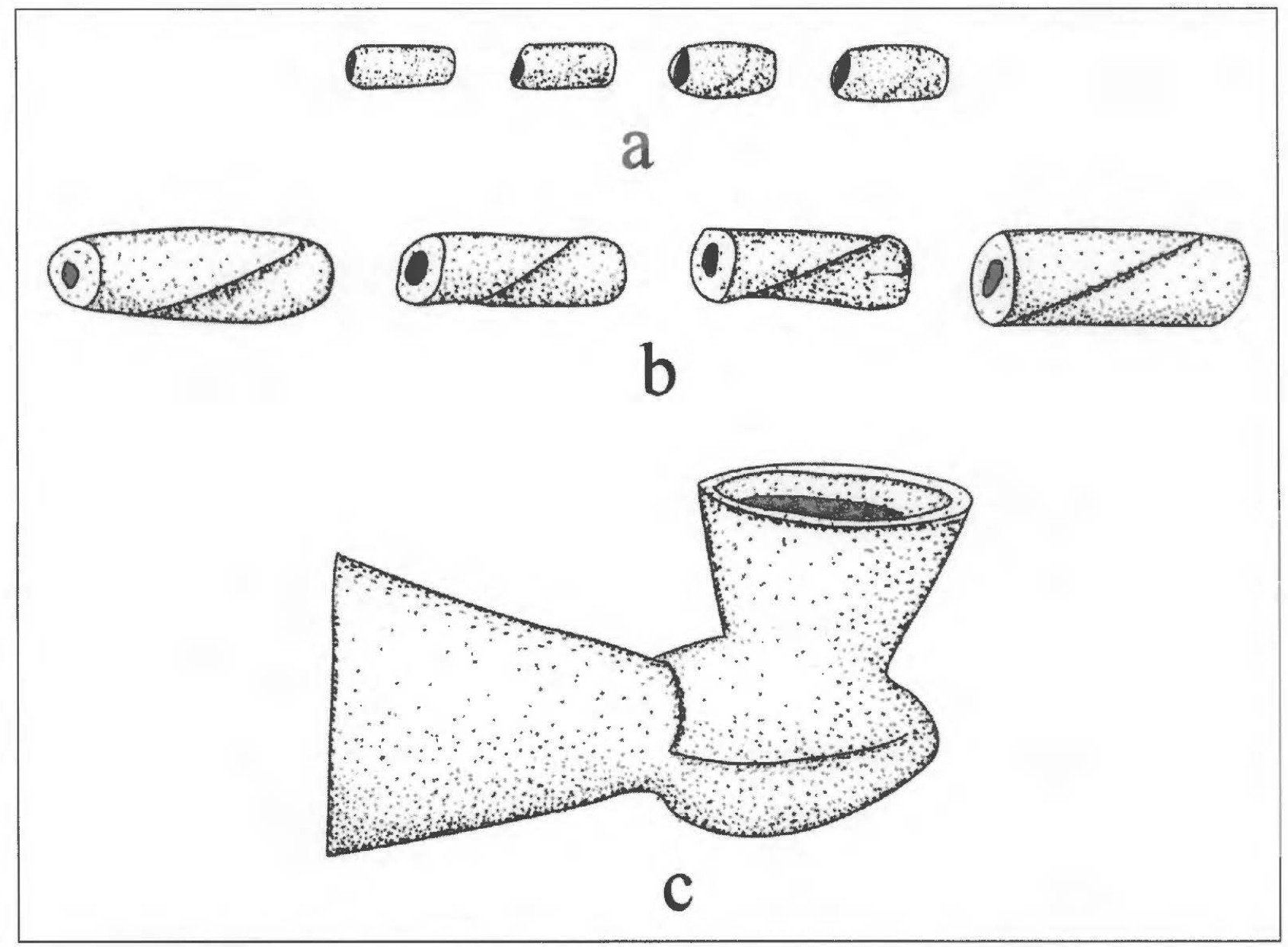

Figure 5. Other funerary offerings from the Caddo burials excavated by W. H. Mathews in 1935: a, conch shell beads, Burial 10; b, conch shell beads, Burial 14; c, elbow pipe, Burial 12.

Vessel drawings included in Mathews (1935) permit the identification of specific now defined ceramic types (i.e., Suhm and Jelks 1962) among a number of the recovered ceramic vessels in these burials (see also discussion of vessels, below). They include:

- Barkman Engraved (Burial 7, 8, 11, 14, 15, 20)

- Bowie Engraved (Burial 3)

- Friendship Engraved (Burial 14, 19)

- Haley Engraved (Burial 6,9)

- Hatchel Engraved (Burial 15, 17, 18, 19)

- Hickory Engraved (Burial 9, 10, 21)

- Karnack Brushed-Incised (Burial 15)

- Means Engraved (Burial 10) 
- Moore Noded (Burial 15, 18)

- Nash Neck Banded (Burial 15, 18, 20)

- Pease Brushed-Incised (Burial 13, 17,21)

- Simms Engraved (Burial 12)

The frequency of Barkman Engraved, Bowie Engraved, and Hatchel Engraved vessels in the burials suggests that many of the burials excavated by Mathews, Jr. were interments that date to after ca. A.D. 1400 to ca. A.D. 1500 or thereabouts, in the early to main part of the Late Caddo period. Other ceramic vessels of the types Friendship Engraved, Haley Engraved, and Pease Brushed-Incised found in these burials likely date to an earlier temporal interval, from ca. A.D. 1200-1400, during the Middle Caddo period, although Pease Brushed-Incised vessels are commonly found in post-A.D. 1400 contexts in a number of sites and locales in East Texas. Furthermore, there are also brushed-incised and brushed-incisedappliqued jars of undetermined type in Burial 1 that likely are associated with burials of Middle Caddo period age at the Mitchell cemetery.

Later post-ca. A.D. 1500 Texarkana phase burials in the area excavated by Mathews, Jr. certainly include only Burial 12 with a Simms Engraved vessel (and a Late Caddo style elbow pipe, see Figure 5c). Other ceramics that may belong to this later period of interments include Karnack Brushed-1ncised, Nash Neck Banded, and Moore Noded, but their occurrence in burials (Burials 15, 18, and 20) with Barkman Engraved and Hatchel Engraved suggests these vessels and burials may date instead to the earlier part of the Late Caddo period use of the cemetery, and not to a post-A.D. 1500 interval.

Finally, earlier, pre-A.D. 1250 burials in the portions of the Mitchell site cemetery excavated by Mathews, Jr. may include Burial 2, which has two plain bowls, and Burial 5; these are in the northern part of the cemetery (see Figure 4). This latter burial has a plain bottle, a zoned incised-punctated jar, and a deep bowl with opposed curvilinear engraved lines and a suspension hole under the lip.

\section{Work by Martin and Mathews}

Glenn Martin and Harry Mathews (believed to be the same person as W. H. Mathews, Jr.) excavated two Caddo burials in an unknown part of the cemetery at the Paul Mitchell site. Both burials (No. 1 and No. 2) were those of adults laid out in an extended supine position, with their heads at the northern end of the burial pits, facing to the south (Figure 6). The burial pits were ca. $2.03 \mathrm{~m}$ in length and $1.22 \mathrm{~m}$ in width, and they were excavated to a depth of $1.47 \mathrm{~m} \mathrm{bs}$, the pits reaching into the top of the clay B-horiLon (Martin 1936).

Burial No. 1 had two ceramic vessels (a bowl with a scalloped rim and a small bottle) provided as funerary offerings. A single engraved vessel of unknown decorative style was in Burial No. 2, along with a marine shell gorget with an engraved cruciform style (see below).

\section{8-1939 WPA Excavations at the Paul Mitchell Site}

The WPA excavations at the Paul Mitchell site were extensive, and began on November 10, 1938. A. M. Woolsey was the archaeologist in charge and E. Glenn Martin was the project's time keeper (Woolsey and Martin 1939:2). During the course of the project, which ended on January 10, 1939, 57 different ancestral Caddo burials were excavated in the cemetery, and habitation features and extensive midden deposits were also identificd and excavated during the work (Figure 7). The burials were identified either through the excavation of a contiguous block of units or "by the broadcast method to a sufficient depth to find all graves" (Woolsey and Martin 1939:2). The WPA archaeologists did discover that the cemetery 


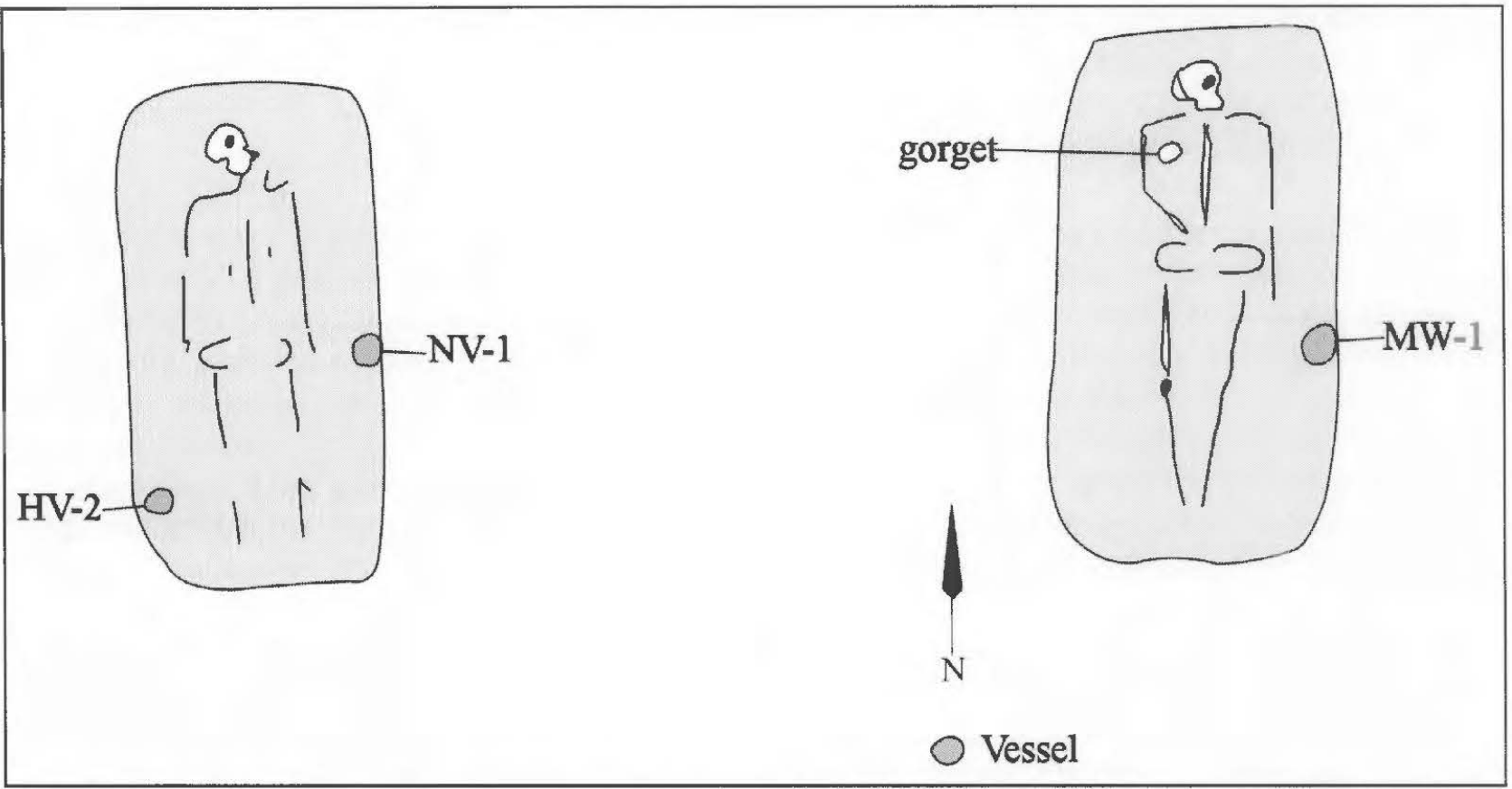

Figure 6. Burials No. 1 and No. 2 excavated in 1936 at the Paul Mitchell site.

had also been rather thoroughly disturbed by pothunters in earlier years. Excavations were abandoned on January 10, 1939, because of rising water levels in Barkman Creek and McKinney Bayou (Woolsey and Martin 1939:195). Burials and other features (i.e., midden deposits and house sites) were considered to be likely to also occur to the north and east of the excavation limits, and it was hoped that excavations could be resumed in the summer of 1939 . However, the WPA investigations were limited only to the Hatchel site at that time.

\section{Cemetery}

Caddo burials were found on the very first day of the WPA excavations at the Mitchell site, but the beginning assigned burial number at the site is Burial 3 (Table 2). Missing numbers in the burial descriptions below were assigned to burials at the Hatchel site, which was being excavated by the WPA at the same time (Woolsey and Martin 1939:3).

Table 2. Burials excavated by the WPA at the Mitchell site.

\begin{tabular}{|c|c|c|c|c|}
\hline $\begin{array}{l}\text { Burial } \\
\text { No. }\end{array}$ & Position & Head orientation & $\begin{array}{r}\text { Depth } \\
(\mathrm{cm})\end{array}$ & Funerary Offerings \\
\hline 3 & Extended & facing northwest & 81 & $\begin{array}{l}\text { fragments of four vessels, } \\
\text { one elbow pipe, and mussel } \\
\text { shells; but disturbed by prior } \\
\text { digging }\end{array}$ \\
\hline 4 & Extended & $\begin{array}{l}\text { facing north-north- } \\
\text { west }\end{array}$ & 117 & $\begin{array}{l}\text { one vessel and mussel shell } \\
\text { with pigment stain; disturbed } \\
\text { by prior digging }\end{array}$ \\
\hline $6 \mathrm{~A}$ & Unknown & facing north & 83 & none; disturbed by prior digging \\
\hline
\end{tabular}




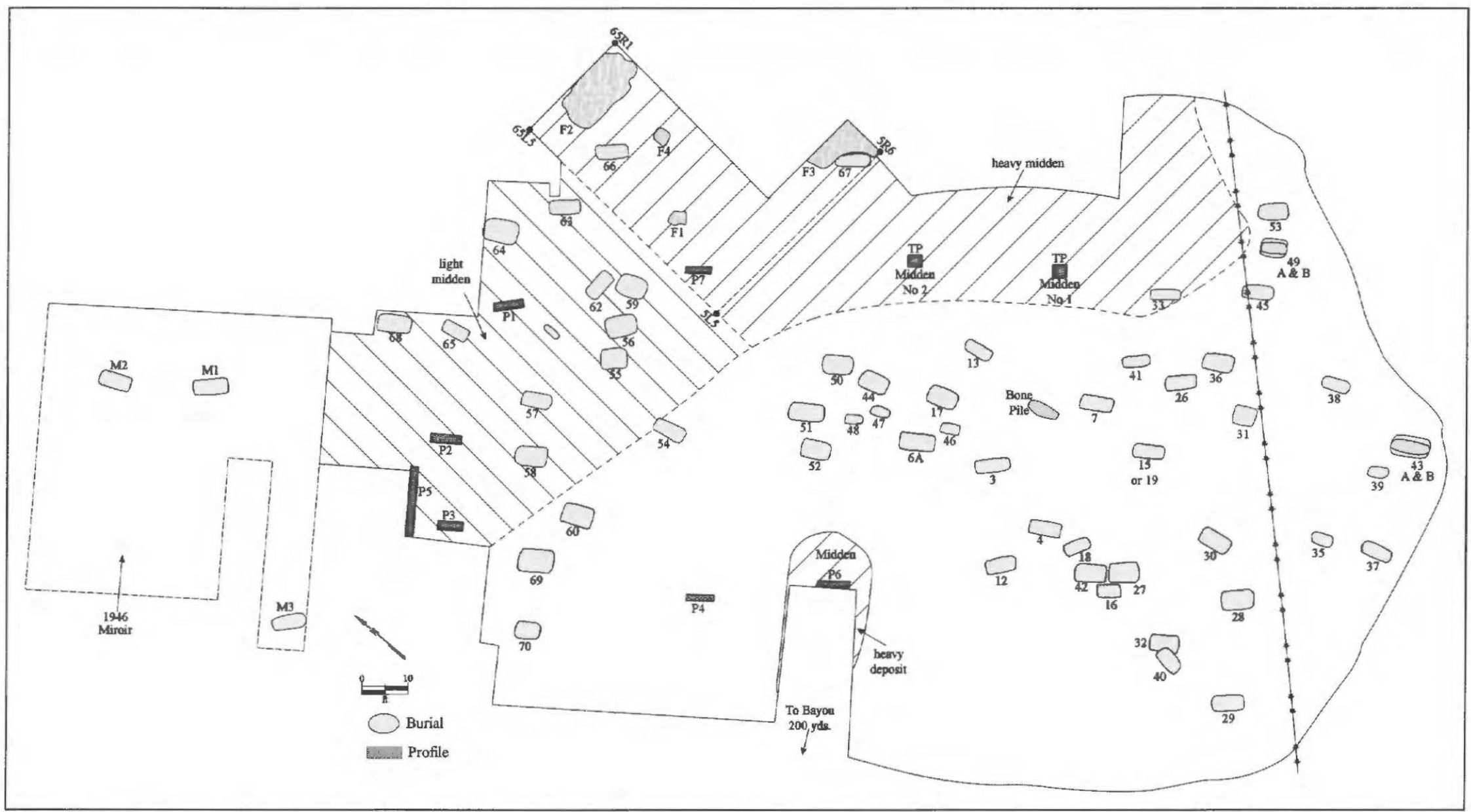

Figure 7. WPA excavations at the Mitchell site, and the area excavated by Pete Miroir in 1946. 
Table 2. Burials excavated by the WPA at the Mitchell site, cont.

\begin{tabular}{|c|c|c|c|c|}
\hline $\begin{array}{l}\text { Burial } \\
\text { No. }\end{array}$ & Position & Head orientation & $\begin{array}{r}\text { Depth } \\
(\mathrm{cm})\end{array}$ & Funerary Offerings \\
\hline $6 \mathrm{~B}$ & Extended & facing north & 99 & $\begin{array}{l}\text { mussel shell and a bone needle; } \\
\text { disturbed by prior digging }\end{array}$ \\
\hline 7 & Extended & facing northwest & 97 & $\begin{array}{l}\text { three ceramic vessels and five } \\
\text { conch shell beads; disturbe } \\
\text { by prior digging }\end{array}$ \\
\hline 12 & Extended & facing northwest & 105 & $\begin{array}{l}\text { seven ceramic vessels, and a } \\
\text { concentration of charcoal on } \\
\text { the left chest area; a mussel } \\
\text { shell hoe; one conch shell } \\
\text { bead under the chin }\end{array}$ \\
\hline 13 & Extended & $\begin{array}{l}\text { facing north- } \\
\text { northwest }\end{array}$ & 36 & $\begin{array}{l}\text { two ceramic vessels } \\
\text { and a mussel shell }\end{array}$ \\
\hline 16 & Extended & facing northwest & 105 & none; disturbed by pris tigging \\
\hline 17 & Extended & facing north & 107 & $\begin{array}{l}\text { two ceramic vessels; disturbed by } \\
\text { prior digging }\end{array}$ \\
\hline 18 & Extended & facing northwest & 112 & none; disturbed by prior digging \\
\hline 19 & Extended & facing northwest & 94 & five ceramic vessels, a ceramic \\
\hline & & & & $\begin{array}{ll}\text { elbow pipe, shell gor } & \text { o e } \\
\text { pin, and } 10 \text { conch she } & \text { ds }\end{array}$ \\
\hline 26 & Extended & facing northwest & 76 & none; disturbed by prior digging \\
\hline 27 & Extended & facing northwest & 112 & none; disturbed by prior digging \\
\hline 28 & Extended & facing northwest & 81 & $\begin{array}{l}\text { five ceramic vessels and one } \\
\text { clay pipe }\end{array}$ \\
\hline 29 & Extended & facing northwest & 117 & $\begin{array}{l}\text { six ceramic vessels; } 18 \text { shell } \\
\text { beads; bird bones }\end{array}$ \\
\hline 30 & Extended & facing north & 107 & $\begin{array}{l}\text { three ceramic vessels; } 5 \mathrm{sl} \\
\text { beads; one mussel shell }\end{array}$ \\
\hline 31 & Extended & facing northwest & 64 & six ceramic vessels \\
\hline 32 & Extended & facing northwest & 102 & $\begin{array}{l}\text { three ceramic vessels; } 1 \text { mussel } \\
\text { shell; } 20 \text { conch sht } 11 \text { beads }\end{array}$ \\
\hline 33 & Extended & facing northwest & 56 & none; disturbed by prior digging \\
\hline 35 & Extended & facing northwest & 56 & three ceramic vessels \\
\hline 36 & Extended & facing northwest & 89 & $\begin{array}{l}\text { seven ceramic vessels; one } \\
\text { clay elbow pipe; } 2 \text { mussel } \\
\text { shells; and } 11 \text { conch shell beads }\end{array}$ \\
\hline 37 & Extended & facing northwest & 51 & $\begin{array}{l}\text { two ceramic vessels and } \\
\text { fragments of possibly five } \\
\text { others; } 2 \text { mussel shells; disturbed } \\
\text { by prior digging }\end{array}$ \\
\hline 38 & Extended & facing northwest & 46 & $\begin{array}{l}\text { one ceramic vessel; charcoal } \\
\text { in the burial fill }\end{array}$ \\
\hline 39 & Extended? & facing northwest? & 58 & none; disturbed by prior digging \\
\hline 40 & Extended & facing northeast & 41 & none \\
\hline 41 & Extended & facing northwest & 41 & two ceramic vessels \\
\hline
\end{tabular}


Table 2. Burials excavated by the WPA at the Mitchell site, cont.

\begin{tabular}{|c|c|c|c|c|}
\hline $\begin{array}{l}\text { Burial } \\
\text { No. }\end{array}$ & Position & Head orientation & $\begin{array}{r}\text { Depth } \\
(\mathrm{cm})\end{array}$ & Funerary Offerings \\
\hline 42 & Extended & facing northwest & 130 & seven ceramic vessels \\
\hline 43 & $\begin{array}{l}\text { Extended } \\
\text { ( } 2 \text { IND.) }\end{array}$ & facing northwest & 86 & $\begin{array}{l}\text { seven ceramic vessels; } 2 \\
\text { mussel shclls ( } 1 \text { with red } \\
\text { pigment); } 7 \text { conch shell beads }\end{array}$ \\
\hline 44 & $\begin{array}{l}\text { Extended } \\
\text { ( } 2 \text { IND.) }\end{array}$ & facing northwest & 69 & $\begin{array}{l}\text { one ccramic vessel; } \\
\text { disturbed by prior digging }\end{array}$ \\
\hline 45 & Extended & facing northwest & 51 & none; disturbed by prior digging \\
\hline 46 & Unknown & unknown & 122 & none; disturbed by prior digging \\
\hline 47 & Unknown & unknown & 76 & none; disturbed by prior digging \\
\hline 48 & $\begin{array}{l}\text { Unknown } \\
\text { (2 IND.) }\end{array}$ & unknown & 20 & none; disturbed by prior digging \\
\hline 49 & $\begin{array}{l}\text { Extended } \\
(2 \text { IND.) }\end{array}$ & facing northwest & $28-46$ & $\begin{array}{l}\text { one ceramic vessel with } \\
\text { Burial } 49 \mathrm{~A} \text {; two ceramic } \\
\text { vessels and a clay pipe with } \\
\text { Burial 49B; disturbed by prior } \\
\text { digging }\end{array}$ \\
\hline 50 & Extended & facing northwest & 107 & none; disturbed by prior digging \\
\hline 51 & Unknown & unknown & 107 & $\begin{array}{l}\text { two clay pipes; disturbed by } \\
\text { prior digging }\end{array}$ \\
\hline 52 & Extended & facing northwest & 81 & $\begin{array}{l}\text { one ceramic vessel; one turtle } \\
\text { shell; disturbed by prior digging }\end{array}$ \\
\hline 53 & Extended & facing northwest & 46 & none; disturbed by prior digging \\
\hline 54 & Extended & facing northwest & 160 & $\begin{array}{l}\text { five ceramic vessels; three } \\
\text { stone projectile points }\end{array}$ \\
\hline 55 & Extended & facing northwest & 71 & $\begin{array}{l}\text { Inass of purple clay pigment; } \\
\text { disturbed by prior digging }\end{array}$ \\
\hline 56 & Extended & facing northwest & 81 & none; disturbed by prior digging \\
\hline 57 & Extended & facing northwest & 91 & none; disturbed by prior digging \\
\hline 58 & Extended & facing northwest & 97 & none; disturbed by prior digging \\
\hline 59 & Extended & facing northwest & 53 & none; disturbed by prior digging \\
\hline 60 & Extended & facing northwest & 81 & $\begin{array}{l}\text { five bone projectile points; } \\
\text { disturbed by prior digging }\end{array}$ \\
\hline 61 & Extended & facing north & 43 & five ceramic vessels \\
\hline 62 & Extended & facing west & 31 & none; disturbed by past plowing \\
\hline 63 & Extended & facing northwest & 24 & $\begin{array}{l}\text { five ceramic vessels; four arrow } \\
\text { points; two turtle shell rattles }\end{array}$ \\
\hline 64 & Extended & facing northwest & 152 & $\begin{array}{l}\text { none; disturbed by prior digging } \\
\text { and only partially exposed by WPA }\end{array}$ \\
\hline 65 & Extended & facing northwest & 46 & one ceramic vessel \\
\hline 66 & Extended & facing northwest & 124 & $\begin{array}{l}\text { three ceramic vessels; one clay } \\
\text { pipe; two bone hair pins or } \\
\text { needles; a celt or scraper; } \\
12 \text { animal bones (may be part } \\
\text { of a necklace) }\end{array}$ \\
\hline
\end{tabular}


Table 2. Burials excavated by the WPA at the Mitchell site, cont.

\begin{tabular}{|c|c|c|c|c|}
\hline $\begin{array}{l}\text { Burial } \\
\text { No. }\end{array}$ & Position & Head orientation & $\begin{array}{r}\text { Depth } \\
(\mathrm{cm})\end{array}$ & Funerary Offerings \\
\hline 67 & Extended & facing west & 25 & none; disturbed by plowing \\
\hline 68 & Extended & facing northwest & 86 & two ceramic vessels \\
\hline 69 & Extended & facing northwest & 137 & $\begin{array}{l}65 \text { shell beads; one clay pipe; } \\
\text { two mussel shells; three ceramic } \\
\text { vessels }\end{array}$ \\
\hline 70 & Unknown & Unknown & $91+$ & $\begin{array}{l}\text { none; burial incompletely } \\
\text { investigated by WPA }\end{array}$ \\
\hline
\end{tabular}

IND.=individuals

Unless the burials had been disturbed by pothunters (i.e., 61 percent of the 54 burials) or plowing, both children and adults had been laid in graves in an extended, supine position; rows of burials are not readily apparent. Most graves held one individual, but five burials had two individua . Most of the deceased were laid in graves oriented southeast-northwest, with their heads in the southern part of the grave, and facing northwest; two burials faced west and one faced south (see Table 2).

Funerary offerings were commonly placed with the deceased Caddo adults and children. These funerary offerings included ceramic vessels $(n=110$ vessels; there were 96 vessels in 24 undisturbed burials, or 4.0 vessels per burial); clay pipes (nine pipes in eight burials); mussel shell valves (14 in 10 burials); one mussel shell hoe; a marine shell gorget in one burial; marine shell beads ( $n=142$ in nine different burials); bone hair pins ( $\mathrm{n}=3$ in two burials) and bone tools (one bone needle); bird and animal bones, laced in: ide several vessels ( $n=3$ burials); a possible animal bone necklace in one burial; turtle shells (in one burial); turtle shell rattles (two in one burial); bone $(n=5)$ and stone projectile points $(n=7)$; one celt; and a pigment stone. The kind and range of funerary offerings in these Caddo burials from the Mitchell site are not significantly different than the funerary offerings placed with the 23 burials excavated in 1935 and 1936 in the cemetery: 2.7 vessels per burial; one clay pipe in one burial; 40 shell beads and a shell gorget in two burials; and a mussel shell with clay pigment in one burial.

The age and sex have been determined for many of the Caddo burials excavated by the WPA in the Mitchell site cemetery that had not been previously disturbed by pothunters (Lee 1997:Table 2). Consequently, it is possible to examine if there were differences between age and sex groups in the range and quantity of funerary offerings that were placed with them at their death. The two child burials (Burials 35 and 61 ) had between them eight ceramic vessels (4.0 vessels per burial) and no other kinds of funerary offerings. The one adolescent burial (Burial 65) had only one ceramic vessel placed in its grave as a funerary offering.

Ten of the burials at the Mitchell site cemetery were adult females (Burials 12-13, 29-31, 38, 4143 , and 68). These adult females had 43 ceramic vessels ( 4.3 per burial, range $1-7$ vessels per br 1 ), 1 mussel shell hoe, 4 mussel shells (that probably held pigment), and 31 conch shell beads (3.I per burial, range 1-18 per burial); the mean number of funerary offerings per adult female burial is 7.9. Seven of the burials at the Mitchell site are adult males (Burials 19, 28, 36, 40, 54, 63, and 66). The funerary offerings placed with these individuals included ceramic vessels $(n=30,4.3$ vessels per burial, range 0 . vessels per burial); 2 mussel shells (that may have held pigment); one marine shell gorget; 21 conch shell beads (3.0 per burial, range $10-11$ per burial); 4 clay pipes ( 0.6 per burial); 3 bone pins ( 0.4 per burial); 7 ar- 
row points ( 1.0 per burial); 1 celt; and 2 turtle shell rattles. The mean number of funerary offerings per adult male burial is 10.1 , about 28 percent more than is the case for the adult female burials. Adult male and female individuals at the site had the same amount of ceramic vessels, mussel shells, and conch shell beads placed as funerary offcrings in graves. Funerary offerings that appear to be specific to the adult males at the Mitchell site are clay pipes, bone pins, arrow points, marine shell gorgets, celts, and turtle shell rattles; mussel shcll hoes are specific to adult females. On this basis, Burial 69, lacking an age and sex determination (see Lee 1997:Table 2), is an adult male because one of the funerary offerings with it is a clay pipe.

In general, the minor variability between child, adult female, and adult male burials in the Mitchell site cemetery with respect to the number and kind of funerary offerings suggest these ancestral Caddo individuals were not significantly different in social status or rank. It is not clear where the elite members of the Nasoni Caddo living at the Hatchel, Mitchell, and Moores sites were buried-perhaps in and in proximity to the earthen mounds at both the Hatchel and Moores sites - but it does not appear, at least on the basis of burial treatment (in extended supine positions in individual graves) and range of funerary offerings that individuals of elite status in the community were buried in the Mitchell site cemetery. The only possible exceptions to this possibility are two adult male burials that had conch shell gorgets (Burial 19 in the WPA excavations and Burial No. 2 in the 1936 excavations).

The bioarchaeological analysis of the skeletal remains from the Mitchell site, as well as burials from the nearby Hatchel and Eli Moores sites, indicates that:

the health of the Caddo peoples... was good. The well-healed fractures, the low to moderate severity of arthritis, mild anemia, and periostitis, imply a fairly successful adaptation. The lack of evidence for interpersonal violence may indicate that relatively little warfare took place among the Caddo and neighboring groups. The cranial modeling and enthesopathies suggest that the Caddo traveled long distances, perhaps for marriage and trade (Lee 1997:176).

\section{Burial 3}

The size of the burial pit ( $2.26 \times 0.81 \mathrm{~m}$ in length and width) and characteristics of the preserved human remains indicate that Burial 3 is that of an adult male (Woolsey and Martin 1939:6). A ceramic elbow pipe was found on the left side of the chest. Two ceramic vessels rested along the left side of the burial pit (Figure 8a-b), while fragments of another (as well as a mussel shell) were resting by the feet (Woolsey and Martin 1939:8).

\section{Burial 4}

This is an 35-45 year old female (Lee 1997:Table 2). This female has evidence of anemia (cribra orbitalia), and also has a cranially modeled skull. A noded ceramic bowl was placed by the right arm of the deceased (Figure 9a-b), and there was a pigment-stained mussel shell resting along the right side of the grave, parallel to the right leg (Woolsey and Martin 1939:13).

\section{Burial 6A}

Burial 6A is a 35-40 year old female (Lee 1997:Table 2). It had been disturbed by pothunters, and its bones lay above those of Burial $6 \mathrm{~B}$ at the bottom of the grave pit. The burial fill had sherds and charcoal pieces (Woolsey and Martin 1939: I7). 

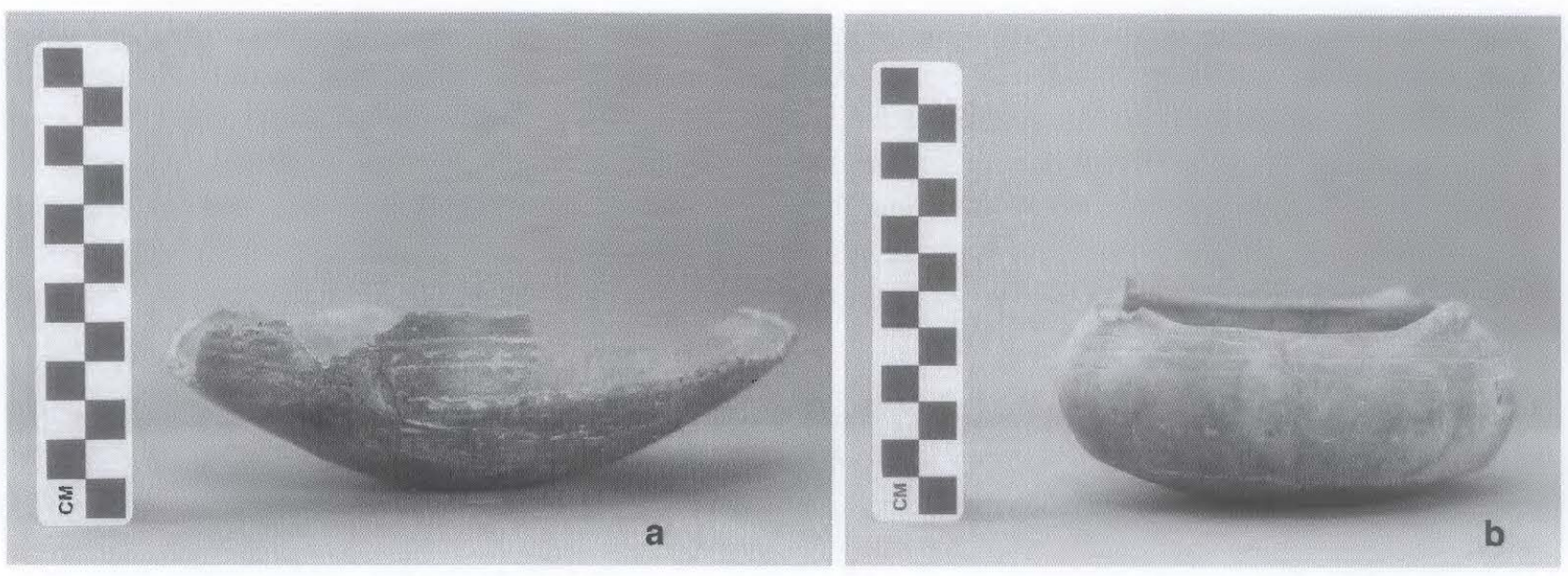

Figure 8. Ceramic vessels from Burial 3: a, Barkman Engraved carinated bowl (6-2-35); b, engraved bowl with rim peaks (6-2-36). Vessel images courtesy of the Texas Archeological Research Laboratory, The University of Texas at Austin.
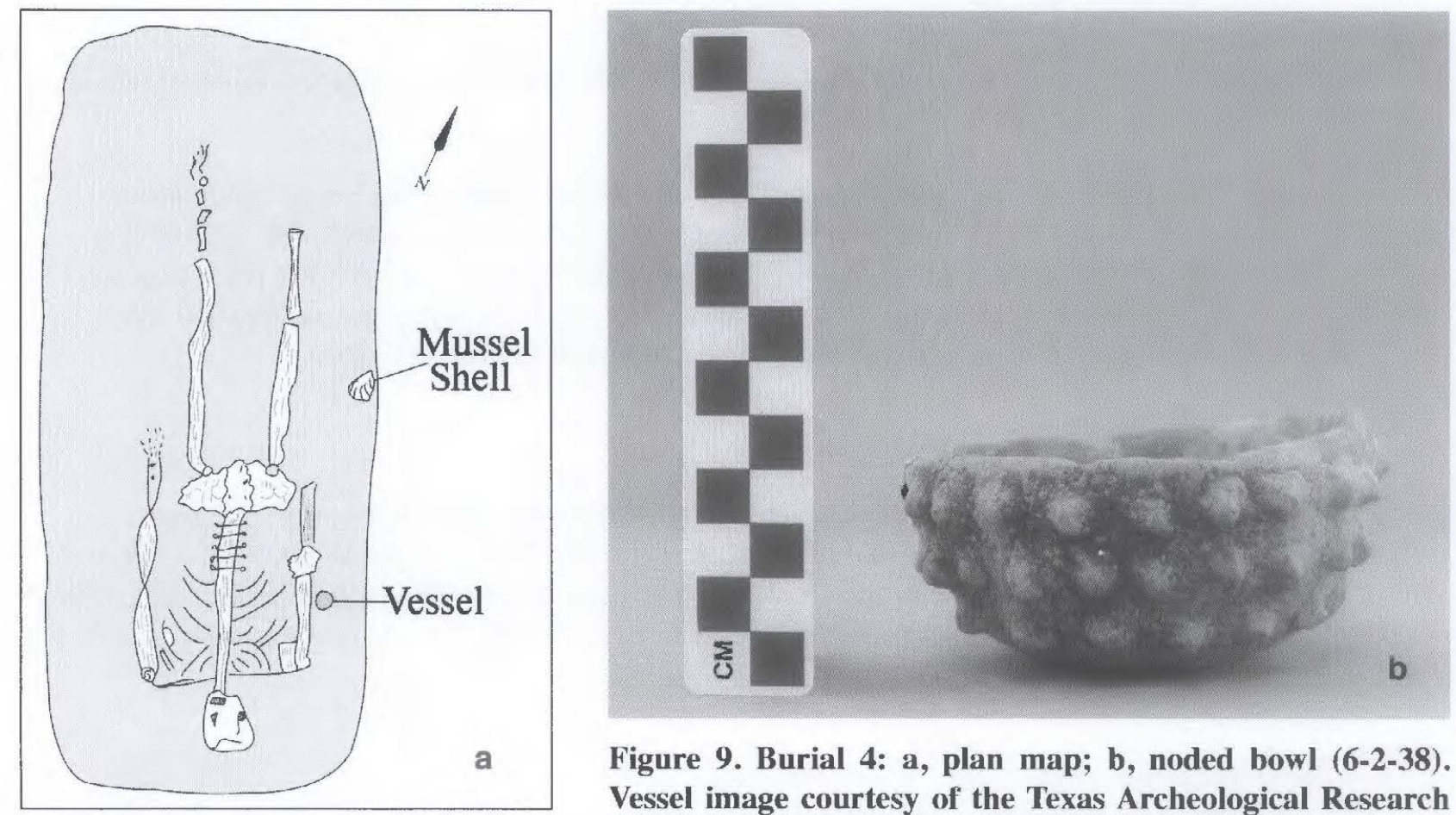

Figure 9. Burial 4: a, plan map; b, noded bowl (6-2-38). Vessel image courtesy of the Texas Archeological Research Laboratory, The University of Texas at Austin.

\section{Burial 6B}

Burial 6B is a 50-60 year old male (Lee 1997:Table 2) with arthritis (Lee 1997:Table 5); Burial 6A apparently was laid directly above it (Woolsey and Martin 1939:18). A large mussel shell was resting by the left leg of the deceased, as well as pieces of a polished bone rod or needle tool. 


\section{Burial 7}

Burial 7 is a 20-25 year old female (Lee 1997:Table 2). This individual has a cranially modeled skull (tabular fronto-vertico-occiptal) (Lee 1997:Table 3), and evidence of arthritis (Lee 1997:Table 5). Among the funerary offerings were five conch shell beads (Woolsey and Martin 1939:35) around the woman's neck, as well as three ceramic vessels previously removed by a pothunter.

\section{Burial 12}

This burial is a 45-55 year old female (Lee 1997:Table 2). This individual has a cranially modeled skull (annular fronto-parallelo-occiptal) (Lee 1997:Table 3), and evidence of arthritis (Lee 1997:Table 5).

Funerary offerings for this female included seven ceramic vessels above the head (a bottle), by the left arm, and mainly by the right foot, as well as a mussel shell hoe near the right hand. A single pearl bead rested by the right shoulder of the deceased (Figure 10a-b).

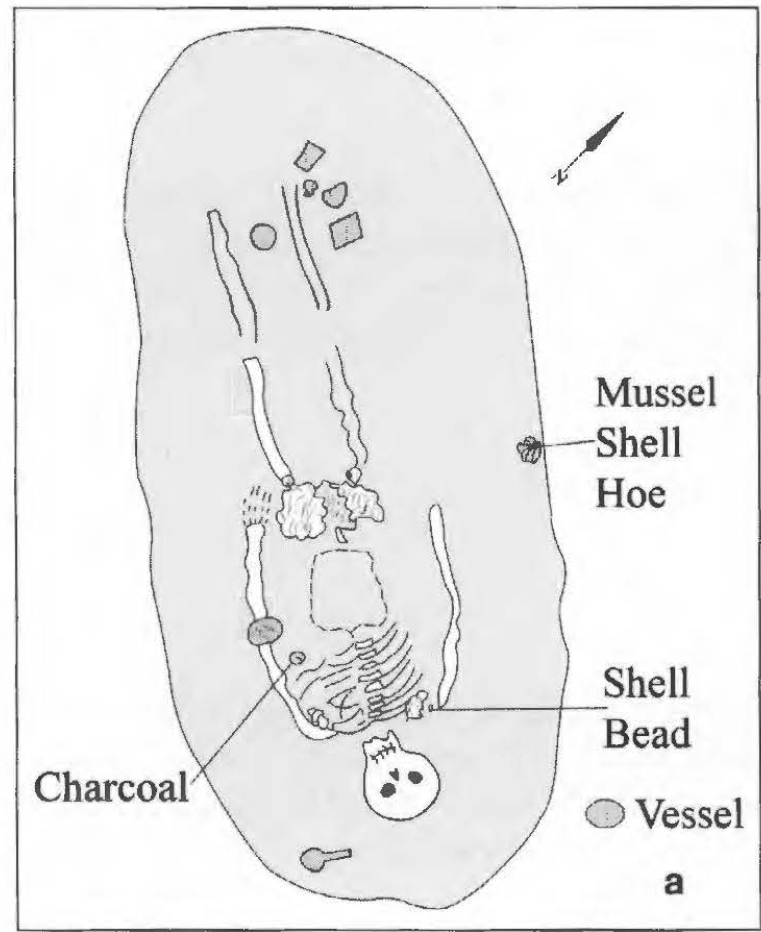

\section{Burial 13}

Burial 13 is a 25-30 year old female (Lee 1997:Table 2). It had been disturbed by modern plowing. The skull of this individual has been cranially modeled, but the style cannot be determined (Lee 1997:Table 3).

Funerary offerings include a mussel shell placed by the right shoulder, a ceramic bottle by the left shoulder, and a ceramic bowl by its feet (Woolsey and Martin 1939:28).

Figure 10. Burial 12: a, plan map; b, engraved bottle (62-39). Vessel image courtesy of the Texas Archeological Research Laboratory, The University of Texas at Austin. 


\section{Burial 16}

'This burial is a $6 \pm 2$ year old Caddo child (Lee 1997: Table 2).

\section{Burial 17}

Burial 17 is that of a 25-30 year adult of indeterminate sex (Lee 1997:Table 2). This individual as a cranially modeled skull (tabular fronto-vertico-occiptal) (Lee 1997:Table 3). Funerary offerings include two ceramic vessels, one on each side of the body near the hip.

\section{Burial 18}

This individual appears to be an adult Caddo male, ca. 25 years of age (Woolsey and Martin 1939:42). It had a cranially modeled skull.

\section{Burial 19}

Burial 19 is a 20-25 year old male (Lee 1997:Table 2). This individual has a cranially modeled skull (tabular fronto-vertico-occiptal) (Lee 1997:Table 3).

Five ceramic vessels were placed as funerary offerings around the head (a bottle), left shoulder, and lower right leg (Figure 11). A Triskele style (cf. Brain and Phillips 1996) conch shell gorget rested on the chest, just below the chin. A bone hair pin rested by the right ear, and a bracelet of 10 conch shell beads was around the right wrist (Woolsey and Martin 1939:46). An elbow pipe was by the right shoulder.

\section{Burial 26}

This is an adult (Woolsey and Martin 1939:50).

\section{Burial 27}

This burial is a 35-45 year old male (Lee 1997:Table 2). This individual has a cranially modeled skull (tabular fronto-vertico-occiptal) (Lee 1997:Table 3). This male also had a bony growth or tumor in its ear, possibly because of "prolonged exposure to cold water through diving" (Lee 1997:175). There were remnants of a ceramic vessel that had been placed between the knees (Woolsey and Martin 1939:52).

\section{Burial 28}

Burial 28 is a 45-55 year old male (Lee 1997:Table 2). This individual had bony spurs on its feet (Lee 1997:Table 4), and evidence of arthritis (Lee 1997:Table 5). There is also evidence of dental anomalies.

Funerary offerings placed with this male included five ceramic vessels, one above the head, anothcr by the left leg, and the other three by the left shoulder and lcft arm. A clay pipe was placed by the right arm (Figure 12).

\section{Burial 29}

This burial is a 20-25 year old female (Lee 1997:Table 2). This individual has a cranially modeled skull (annular fronto-parallelo-occiptal) (Lee 1997:Table 3). 


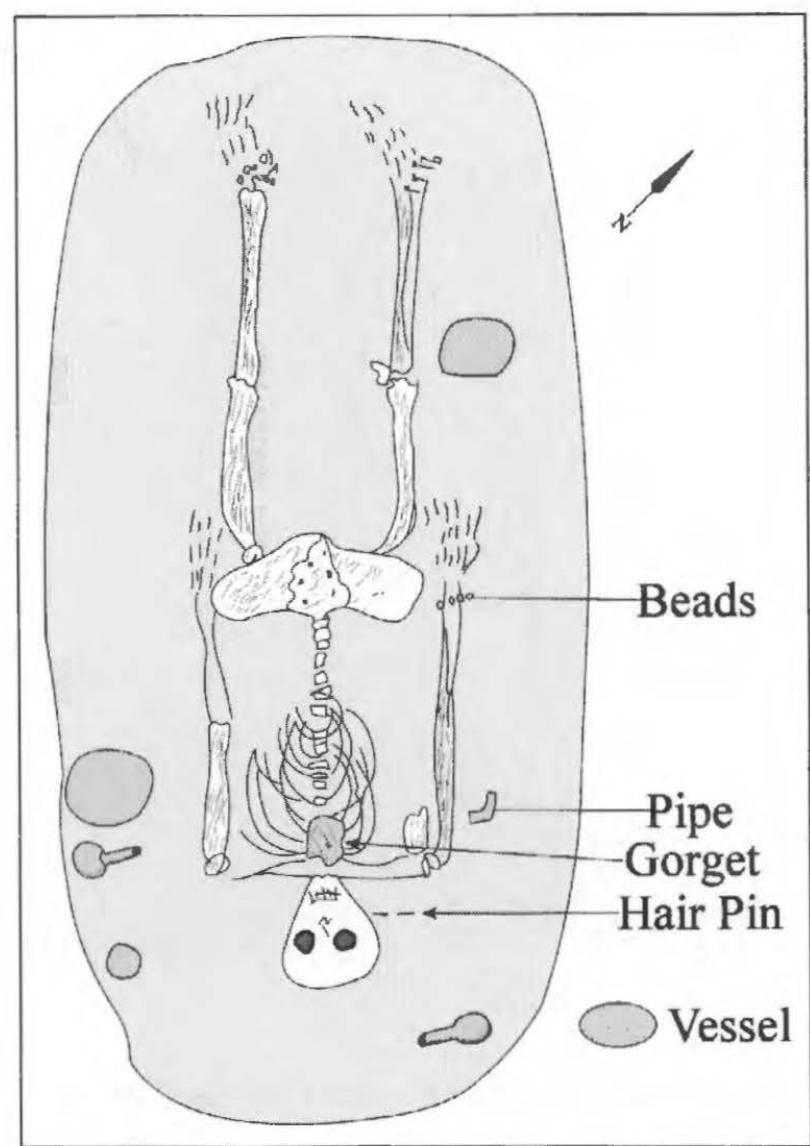

Figure 11. Burial 19 plan map.

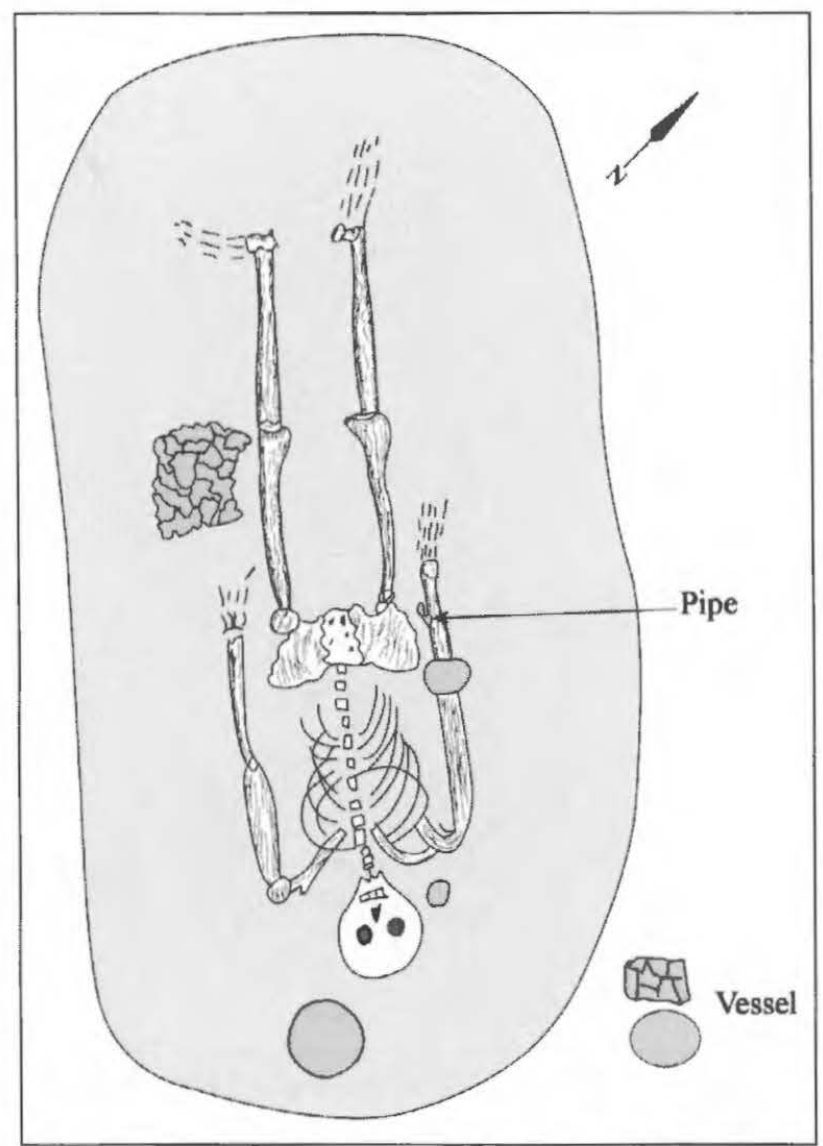

Figure 12. Burial 28 at the Paul Mitchell site.

Funerary offerings with this female include six ceramic vessels, conch shell beads $(n=18)$ around her neck, and bird bones placed near the left wrist. The ceramic vessels were placed on the left side of the chest, by the left hip, and from the right shoulder to the lower right leg (Figure 13).

\section{Burial 30}

This is the burial of a 25-30 year old female (Lee 1997:Table 2). Funerary offerings placed with the deceased include five small conch shell beads around her neck, a mussel shell by the left side of her head, and three ceramic vessels: a bottle by the right shoulder, a bowl by the upper left leg, and a small jar between the lower legs (Figure 14).

\section{Burial 31}

There were two individuals in this burial: a $3 \pm 1$ year old child (31A) and an adult of indeterminate age and sex (Lee 1997:Table 2). Woolsey and Martin's notes (1939:67), however, make no reference to skeletal remains from two individuals in this burial, but they suggest the remains they noted and drew in plan view are from a child about 10 years of age.

Funerary offerings include six ceramic vessels. One was placed between the legs of the probable adult, another (crushed) by the feet, a jar by the left side of the head, and three vessels on the right side of the body: by the shoulder, by the right hand, and by the upper right leg (Figure 15). 


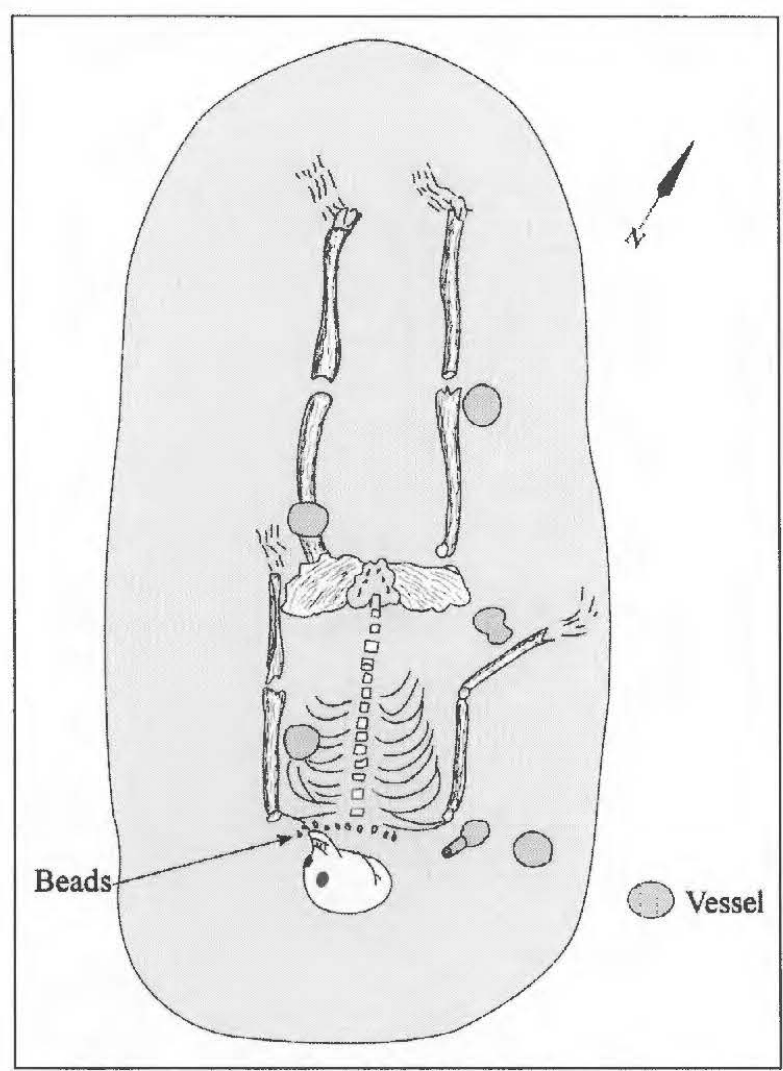

Figure 13. Burial 29 at the Paul Mitchell site.

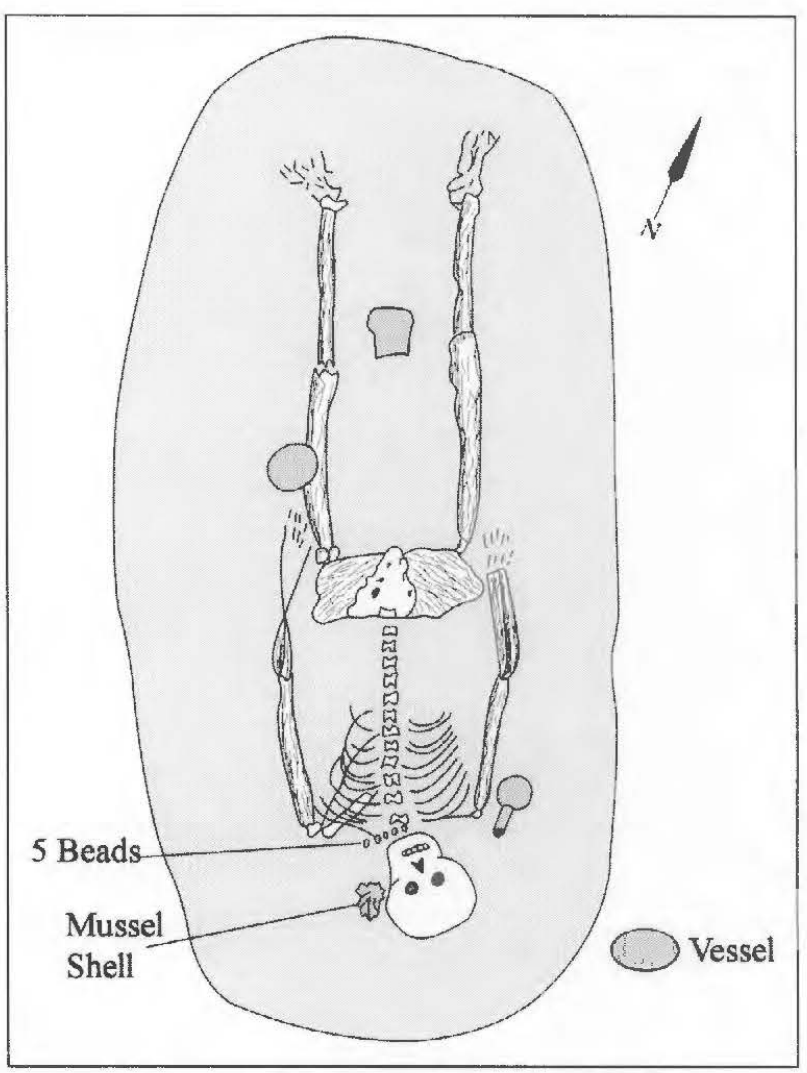

Figure 14. Burial 30 at the Paul Mitchell site.

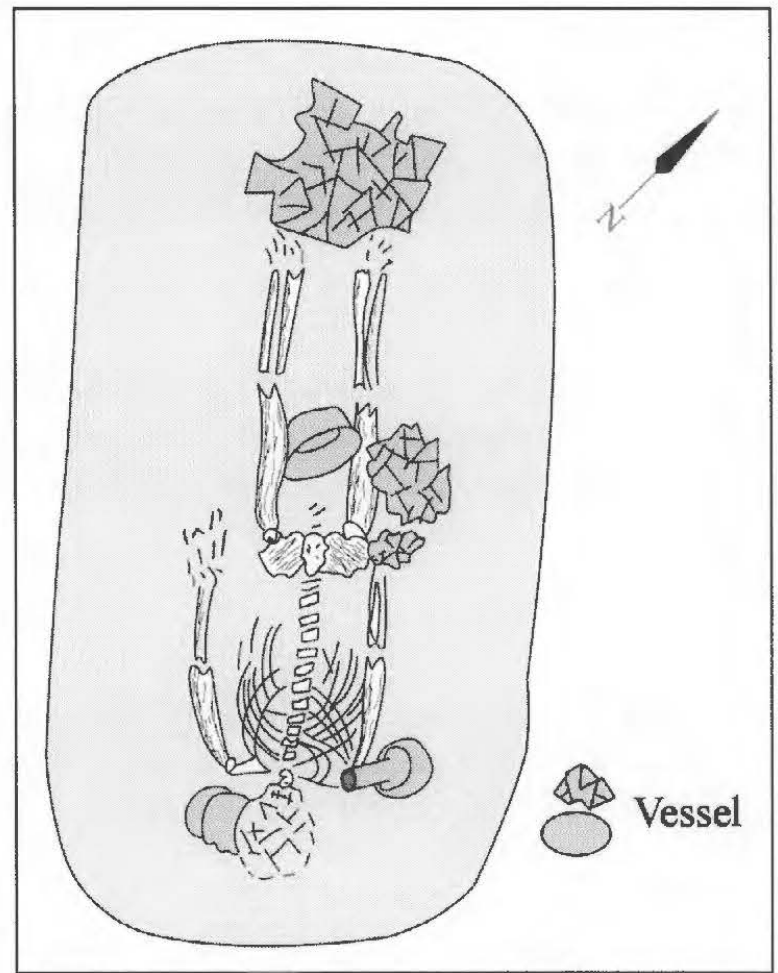

Figure 15. Burial 31 at the Paul Mitchell site. 


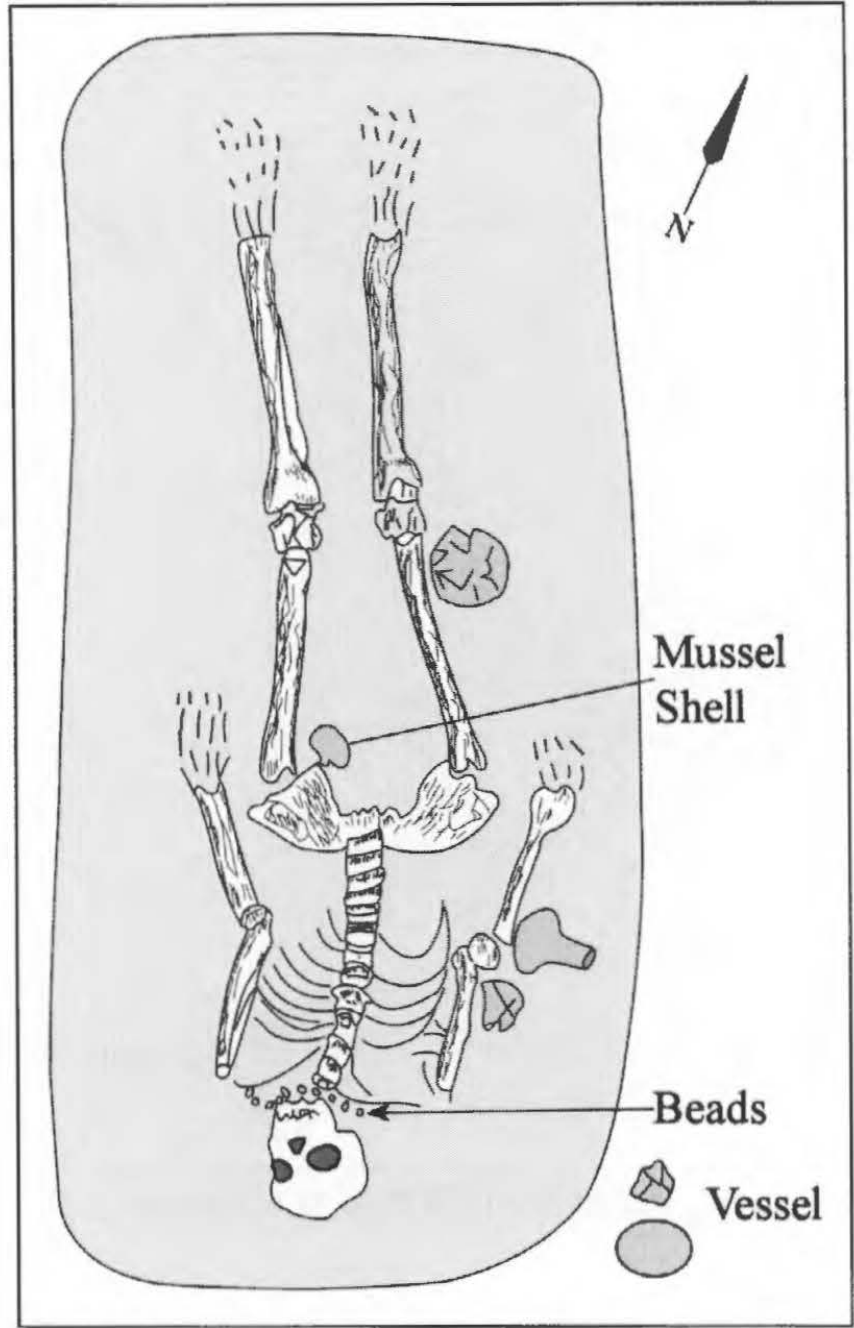

Figure 16. Burial 32 at the Paul Mitchell site.

\section{Burial 32}

This burial is that of an adult (Woolsey and Martin 1939:71), possibly a female. Funerary offerings with the deceased included a necklace of 20 conch shell beads, a mussel shell by the left hip, and three ceramic vessels by the right side of the body, from the upper arm to the knee area (Figure 16).

\section{Burial 33}

Burial 33 is that of an adult male of unknown age (Lee 1997:Table 2).

\section{Burial 35}

Burial 35 is a child between $7 \pm 2$ years of age (Lee 1997:Table 2). This individual has a cranially modeled skull (tabular fronto-vertico-occiptal) (Lee 1997:Table 3), and badly bowed lower legs, likely because the upper left leg had been broken when the child was buried (Woolsey and Martin 1939:79, 81). Funerary offerings with the deceased include a ceramic bottle near the right side of the head, another vessel by the right hip, and a fragmentary vessel by the lower right foot (Figure 17). 


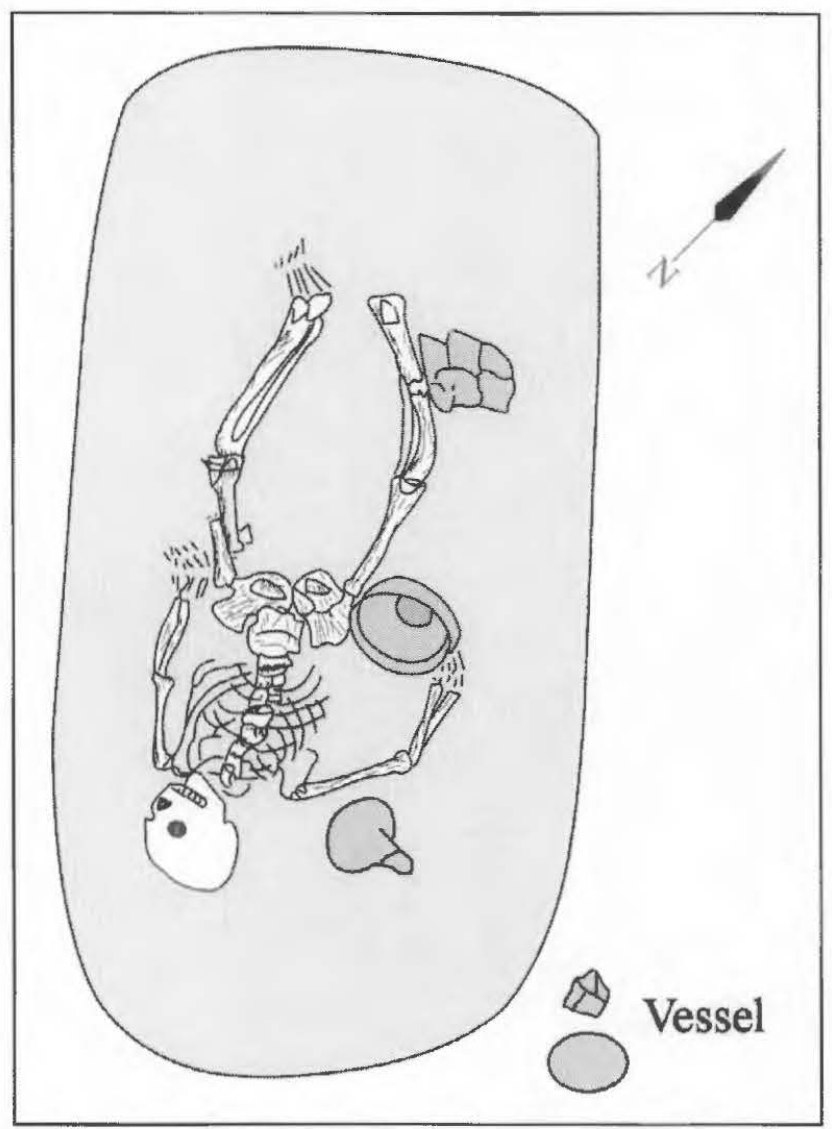

Figure 17. Burial 35 at the Paul Mitchell site.

\section{Burial 36}

This is a burial of a 35-45 year old male (Lee 1997:Table 2). This male has evidence of anemia (cribra orbitalia), a cranially modeled skull (tabular fronto-parallelo-occipital) (Lee 1997:Table 3), and arthritis (Lee 1997:Table 5). There is also evidence of dental anomalies (Lee 1997:175).

This individual was relatively richly furnished with funerary offerings. Two mussel shell valves were placed in the grave by the lower left leg and the right shoulder, 11 conch shell beads were in a bracelet on the right hand, while a clay elbow pipe was resting by the lower right arm (Figure 18). The seven ceramic vessels placed in the grave include a water bottle by the right shoulder and right side of the skull, another vessel above the left side of the head, three vessels by the right arm and lower right leg, and two other vessels between the lower legs.

\section{Burial 37}

Burial 37 is a 25-30 year old female (Lee 1997:Table 2). This individual has a cranially modeled skull (tabular fronto-vertico-occiptal) (Lee 1997:Table 3), and evidence of arthritis (Lee 1997:Table 5). Funerary offerings in this disturbed burial include two mussel shell valves near the left side of the head, two ceramic vessels by the lower right leg, and fragments of possibly other vessels along the left side of the body from the right shoulder to the left knee (Figure 19). 


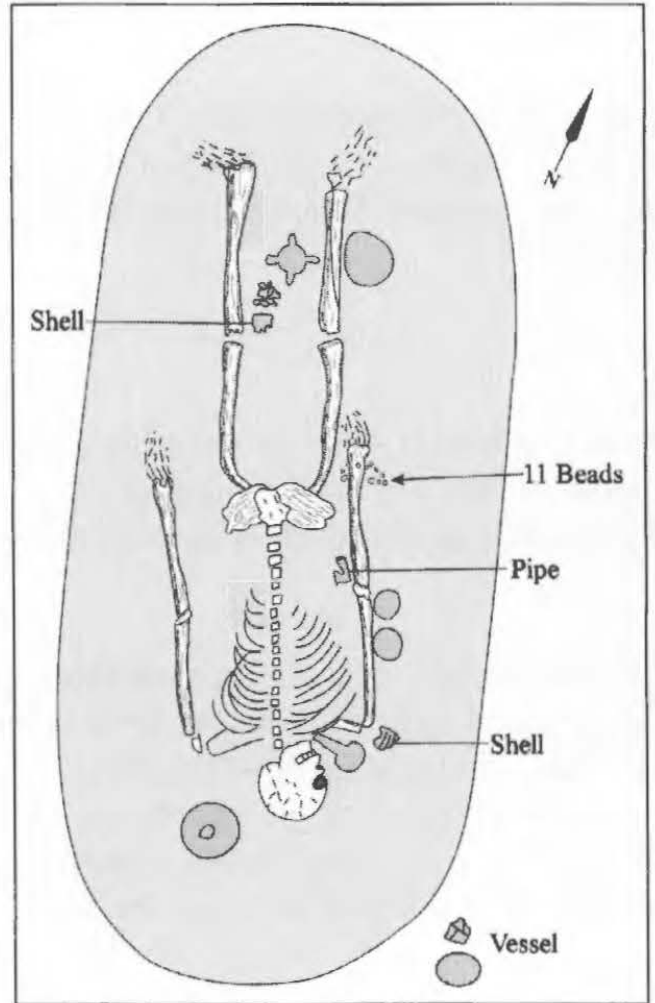

Figure 18. Burial 36 at the Paul Mitchell site.

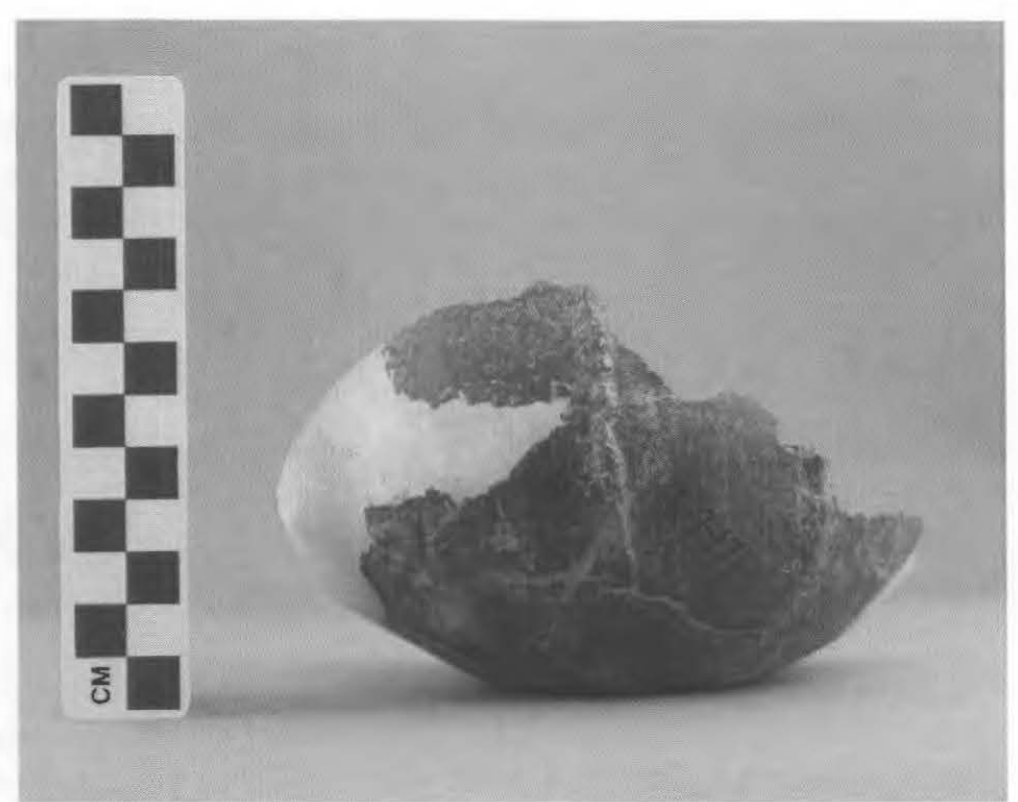

Figure 19. Appliqued jar vessel section (6-2-171) from Burial 37 at the Mitchell site. Vessel image courtesy of the Texas Archeological Research Laboratory, The University of Texas at Austin.

\section{Burial 38}

This burial is that of a 25-30 year old Caddo female (Lee 1997:Table 2), with evidence of dental anomalies (Lee 1997:175). The one funerary offering with this female was a ceramic bottle placed by the right side of the head and atop the right shoulder.

\section{Burial 39}

Burial 39 had been badly disturbed by pothunters before the commencement of the UT excavations. Woolsey and Martin (1939:95) indicate it is the burial of an adult.

\section{Burial 40}

Burial 40 is a $20-25$ year old male (Lee 1997:Table 2). This individual has a cranially modeled skull (tabular fronto-parallelo-occiptal) (Lee 1997:Table 3).

\section{Burial 41}

This burial is a 25-35 year old female (Lee 1997:Table 2). This individual has a cranially modeled skull (tabular fronto-vertico-occiptal) (Lee 1997:Table 3) and evidence of arthritis (Lee 1997:Table 5).

Funerary offerings for this female consisted of two ceramic vessels. A jar was placed between the right arm and the chest, while a carinated bowl was resting on the upper right pelvis. 


\section{Burial 42}

Burial 42 is a 35-45 year old Caddo female (Lee 1997:Table 2), with evidence of arthritis (Lee 1997:Table 5). Funerary offerings placed with the deceased were seven ceramic vessels. There was a bottle by the right shoulder, two jars on the left side of the upper body, and three bowls and a jar by the right side of the body from the upper arm to the lower right foot (Figure 20).

\section{Burial 43}

There were two individuals closely placed together in this grave (Figure 21). One (Burial 43A) is that of an adult female 45-55 years of age (Lee 1997:Table 2). This individual has a cranially modeled skull (tabular fronto-vertico-occiptal) (Lee 1997:Table 3). The second individual (Burial 43B) is an adult male, perhaps 40 years of age (Woolsey and Martin 1939:109).

Funerary offerings included seven ceramic vessels, two mussel shells, and five small conch shell beads. Four of the ceramic vessels (including one with green clay pigment in it) were placed above the heads of both individuals, a bottle was by the left hand of Burial 43B, while a rattle bowl (with yellow ochre inside it) rested on the right shoulder of Burial 43A and a bowl lay along the right lower leg (Woolsey and Martin 1939:110) (see Figure 21). The mussel shell valves were placed by the right foot of Burial 43A. The conch shell beads were under the chin of Burial 43B (see Figure 19), and are probably part of a necklace.

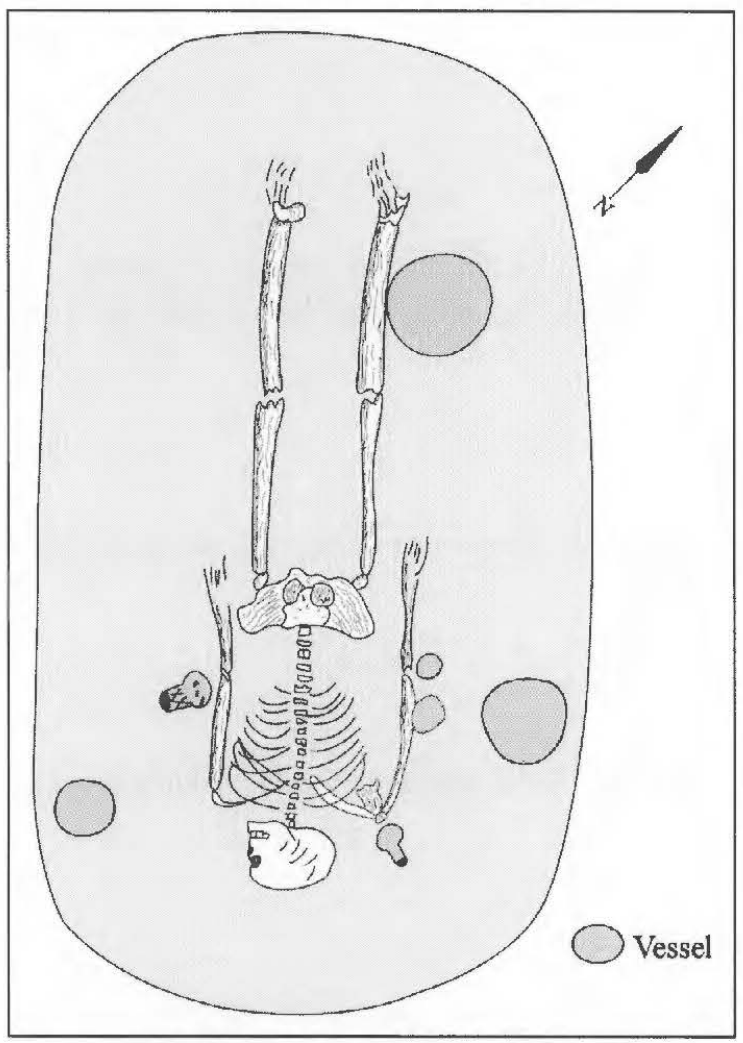

Figure 20. Burial 42 at the Paul Mitchell site.

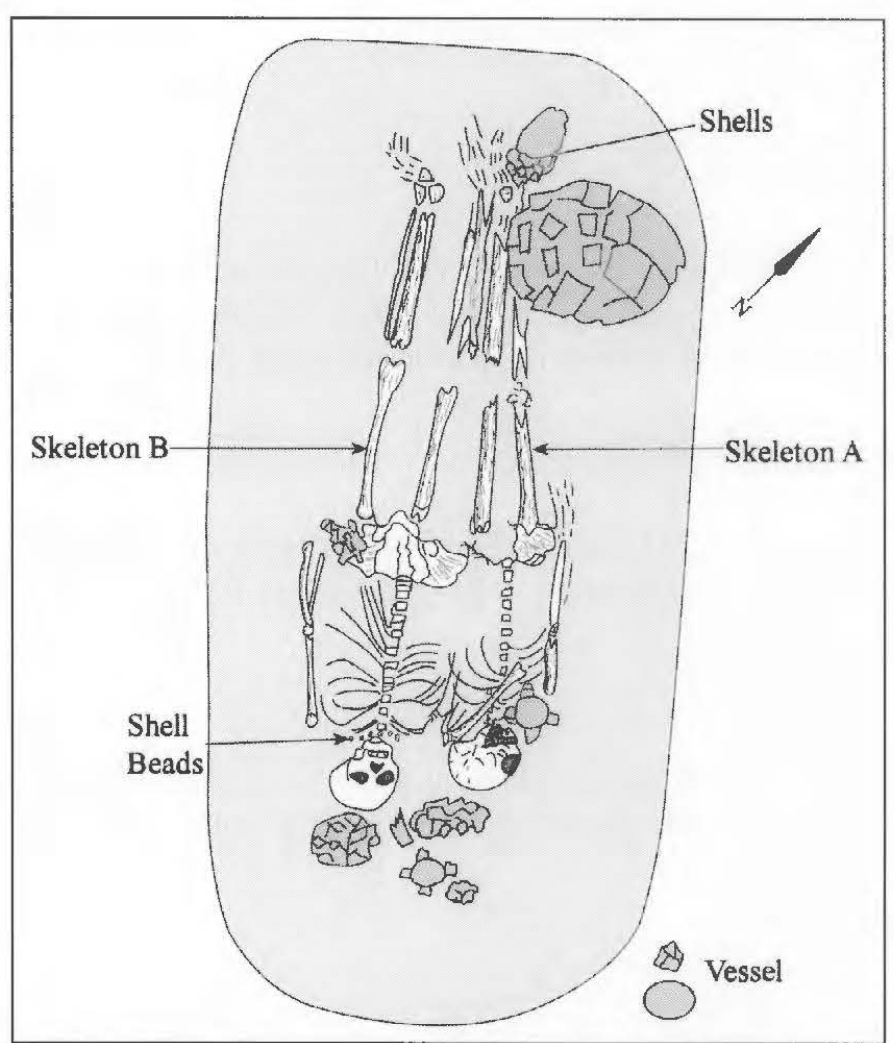

Figure 21. Burial 43A and $43 B$ at the Paul Mitchell site. 


\section{Burial 44}

Burial 44 includes a 3-6 month old child (Lee 1997:Table 2) and an adult, possibly a female (Woolsey and Martin 1939:114). This child has evidence of anemia (cribra orbitalia). A ceramic bottle was the only funerary offering, and it had been placed in the grave along the right side of the child.

\section{Burial 45}

This is the burial of a 25-30 year old female (Lee 1997:Table 2). This fcmale has evidence of anemia (cribra orbitalia).

\section{Burial 46}

This disturbed burial is that of an adult of indeterminate age and sex.

\section{Burial 47}

This is the disturbed burial of a $5 \pm 2$ year old child (Lee 1997:Table 2).

\section{Burial 48}

There are human skeletal remains from a minimum of two individuals in Burial 48, which was disturbed by pothunters, such that the human remains "were scattered over area about 2 foot square" (Woolsey and Martin 1939:120). One is a 9-11 year old child of indeterminate sex (Lee 1997:Table 2). The other, an adult, had evidence of bone spurs on its femur (Lee 1997:Table 4).

\section{Burial 49 A}

Burial 49A is a 25-30 year old female (Lee 1997:Table 2) with Schmorl's nodes on its vertebrae (Lee 1997:Table 4) and evidence of arthritis (Lee 1997:Table 5). It was placed in the grave directly above Burial 49B (Woolsey and Martin 1939:124). One ceramic vessel had been placed by the lower left foot as a funerary offering.

\section{Burial $49 B$}

Burial 49B is a $30-40$ year old male (Lee 1997:Table 2) resting about $18 \mathrm{~cm}$ below Burial 49A in the same grave. This individual has a cranially modeled skull of undetermined form (Lee 1997: Table 3), smashed phalanges, and arthritis in the elbow (Lee 1997:Table 5). Associated funerary offerings include two ceramic vessels by the right leg as well as a clay pipe, but the location of the pipe in the grave was not specified by Woolsey and Martin (1939:125).

\section{Burial 50}

This badly disturbed burial is an adult of indeterminate age and sex (Lee 1997:Table 2). Although there were no funerary offerings remaining in the grave, the fill contained "considerablc small chunks and flecks of charcoal" (Woolsey and Martin 1939:128). 


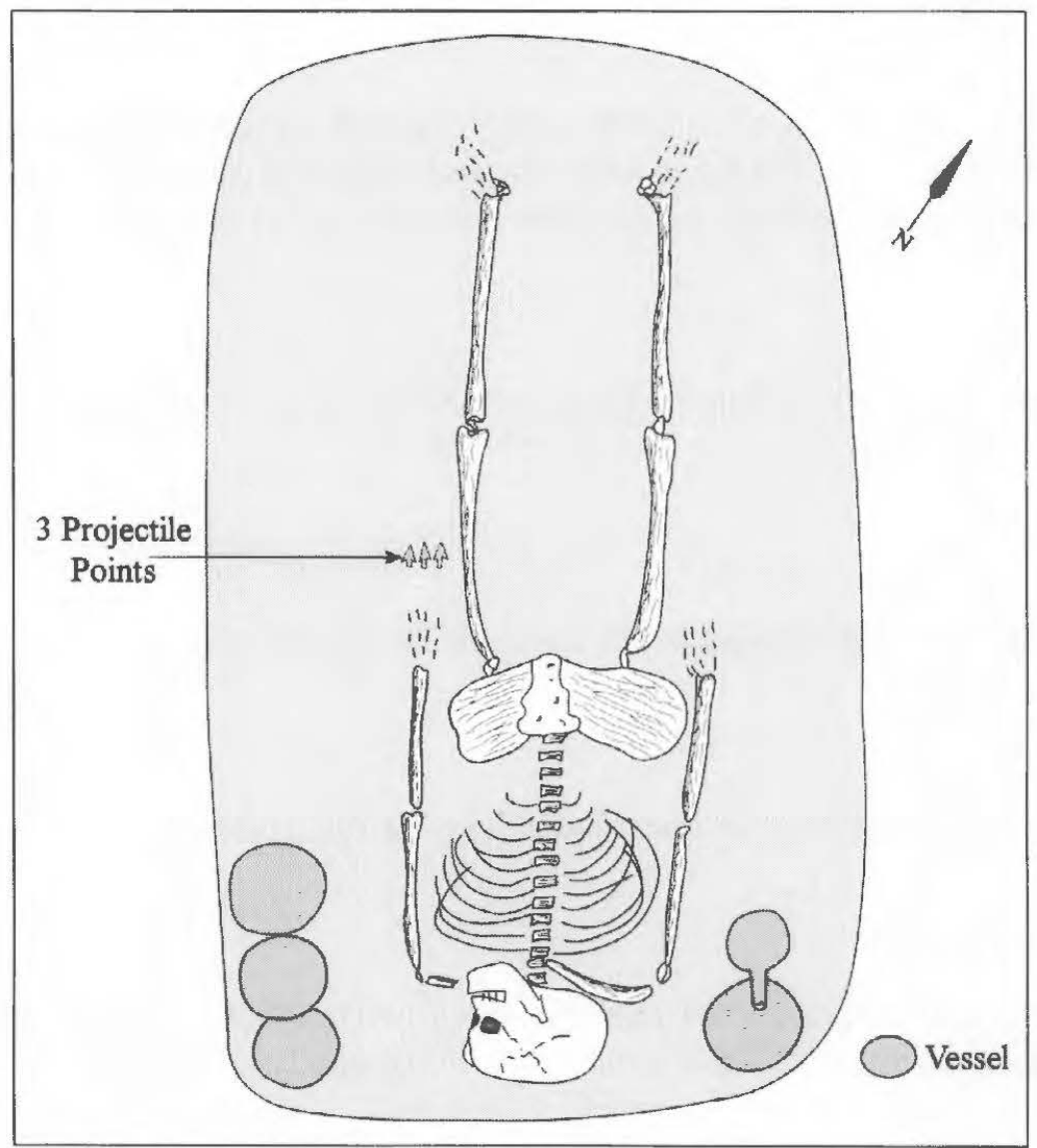

Figure 22. Burial 54 at the Paul Mitchell site.

\section{Burial 51}

This is the badly disturbed burial of a 30-40 year old male (Lee 1997:Table 2). The only remaining funerary offerings were two clay pipes.

\section{Burial 52}

Burial 52 is that of a 13-17 year old of indeterminate sex (Lee 1997:Table 2). There is evidence of a developmental disorder in this individual, namely osteochondritis dessecans (Lee 1997:175). Associated funerary offerings with this disturbed burial were one ceramic jar placed near the right shoulder and a turtle shell under the left arm and hand. Inside this Pease Brushed-Incised jar were the bones of a passenger pigeon.

\section{Burial 53}

This is the disturbed burial of a 50-60 year old Caddo male (Lee 1997:Table 2). This individual has a cranially modeled skull (tabular fronto-vertico-occiptal) (Lee 1997:Table 3), bony spurs on its feet (Lee 1997:Table 4), and evidence of arthritis (Lee 1997:Table 5). There is also evidence of dental anomalies (Lee 1997:175). 


\section{Burial 54}

Burial 54 is an adult male, 35-45 years of age at death (Lee 1997:Table 2). This individual has a cranially modeled skull (tabular fronto-vertico-occiptal) (Lee 1997:Table 3). There is also evidence of various traumas to the skeleton, including Schmorl's nodes, a fibula fracture, smashed phalanges, and various bony spurs (Lee 1997:Table 4), as well as arthritis (Lee 1997:Table 5). This burial is by far the deepest interment in the Mitchell site cemetery (see Table 2).

Funerary offerings include five ceramic vessels, two by the upper right arm and shoulder and three by the upper left arm, shoulder, and parallel to the head. Three possible Bassett arrow points (Woolsey and Martin 1939:147) were placed just below the left hand of the deceased (Figure 22).

\section{Burial 55}

This badly disturbed burial is a 25-30 year old male (Lee 1997:Table 2). The one remaining funerary offering was a mass of purple clay pigment between the legs and near the left knee (Woolsey and Martin 1939:148).

\section{Burial 56}

Burial 56 is the badly disturbed burial of a 20-25 year old Caddo female (Lee 1997:Table 2). This individual has a cranially modeled skull (tabular fronto-vertico-occiptal) (Lee 1997:Table 3). There were no remaining funerary offerings.

\section{Burial 57}

This is the badly disturbed burial of an adult female of indeterminate age (Lee 1997:Table 2).

\section{Burial 58}

This is the badly disturbed burial of a 50-60 year old male (Lee 1997:Table 2). This male had smashed phalanges and bony spurs on its feet, evidence of arthritis, and a bony lesion on one rib that may be the product of a blood clot or damage from smoking (Lee 1997:173). This individual also had a bony growth or tumor in its ear, possibly because of "prolonged exposure to cold water through diving" (Lee 1997:175).

\section{Burial 59}

Burial 59 is a 20-25 year old female (Lee 1997:Table 2) that was badly disturbed by pothunters some time prior to the WPA investigations. This female had a fractured clavicle and Schmorl's nodes on its vertebrae (Lee 1997:Table 4). This individual also had bilateral brachydactyly (abnormal development of the fingers or toes) of its feet (Lee 1997:175).

\section{Burial 60}

This is the badly disturbed burial of a 25-30 year old male (Lee 1997:Table 2), with evidence of arthritis (Lee 1997:Table 5). The only remaining funerary offerings were five stemmed bone projectile points lying in a group by the left knee, all with the tips facing to the northwest (Woolsey and Martin 1939:161). The bone projectile points had straight stems and flat bases, and ranged from $3.1-4.3 \mathrm{~cm}$ in length, $1.0-1.3 \mathrm{~cm}$ wide, and $2.5-5 \mathrm{~mm}$ thick. 


\section{Burial 61}

Burial 61 is that of a young child between 1-2 years of age at death (Lee 1997:Table 2). Funerary offerings placed with this child consisted of five ceramic vessels, four on either side of the head or above it (including one vessel placed inside another), and the fifth vessel by the left hand (Figure 23).

\section{Burial 62}

This is the burial of a 20-25 year old male (Lee 1997:Table 2) that had apparently been disturbed by modern plowing. This individual has a cranially modeled skull (tabular fronto-vertico-occiptal) (Lee 1997:Table 3). No funerary offerings remained in the burial pit.

\section{Burial 63}

This burial is a 20-25 year old male (Lee 1997:Table 2). This individual has a cranially modeled skull (tabular fronto-parallelo-occiptal) (Lee 1997:Table 3). There was an interesting assortment of funerary offerings placed with this individual, including four stone arrow points (with the tips facing northwest)

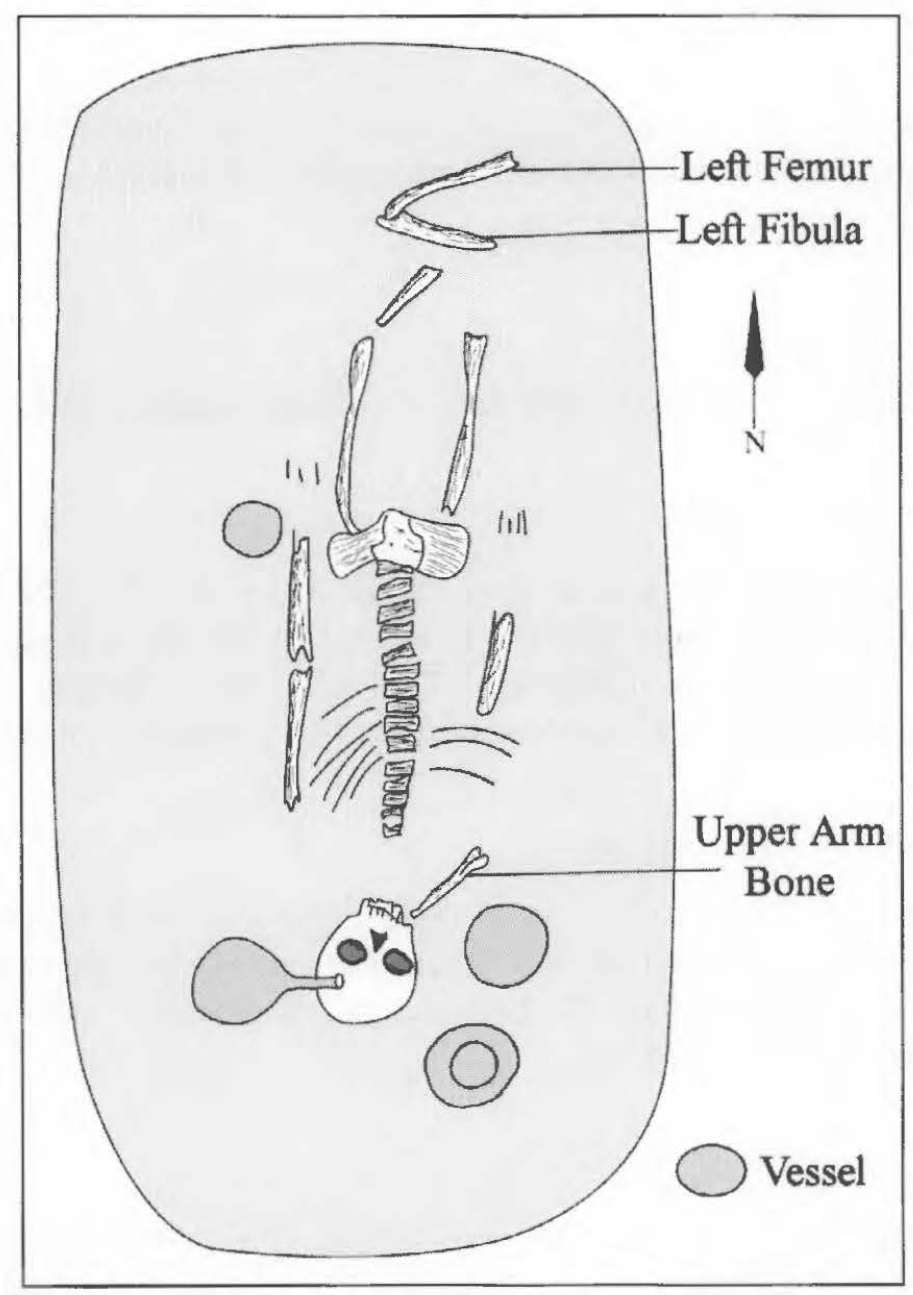

Figure 23. Burial 61 at the Paul Mitchell site. 
above the left shoulder, two turtle shell rattles (and associated pebbles) on either ankle (and probably once attached to the legs), and five ceramic vessels. All of the ceramic vessels were placed in a row along the right side of the body, from the lower right arm to the right knee (Figure 24).

\section{Burial 64}

This burial of a Caddo adult of undetermined sex was only investigated to a limited basis by the WPA because of water seeping in the grave during the excavations (Woolsey and Martin 1939:175). The excavations were filled in and abandoned before they were completed.

\section{Burial 65}

Burial 65 is a 10-12 year old of indeterminate sex (Lee 1997:Table 2). A single ceramic vessel had been placed as a funerary offering next to the right knee.

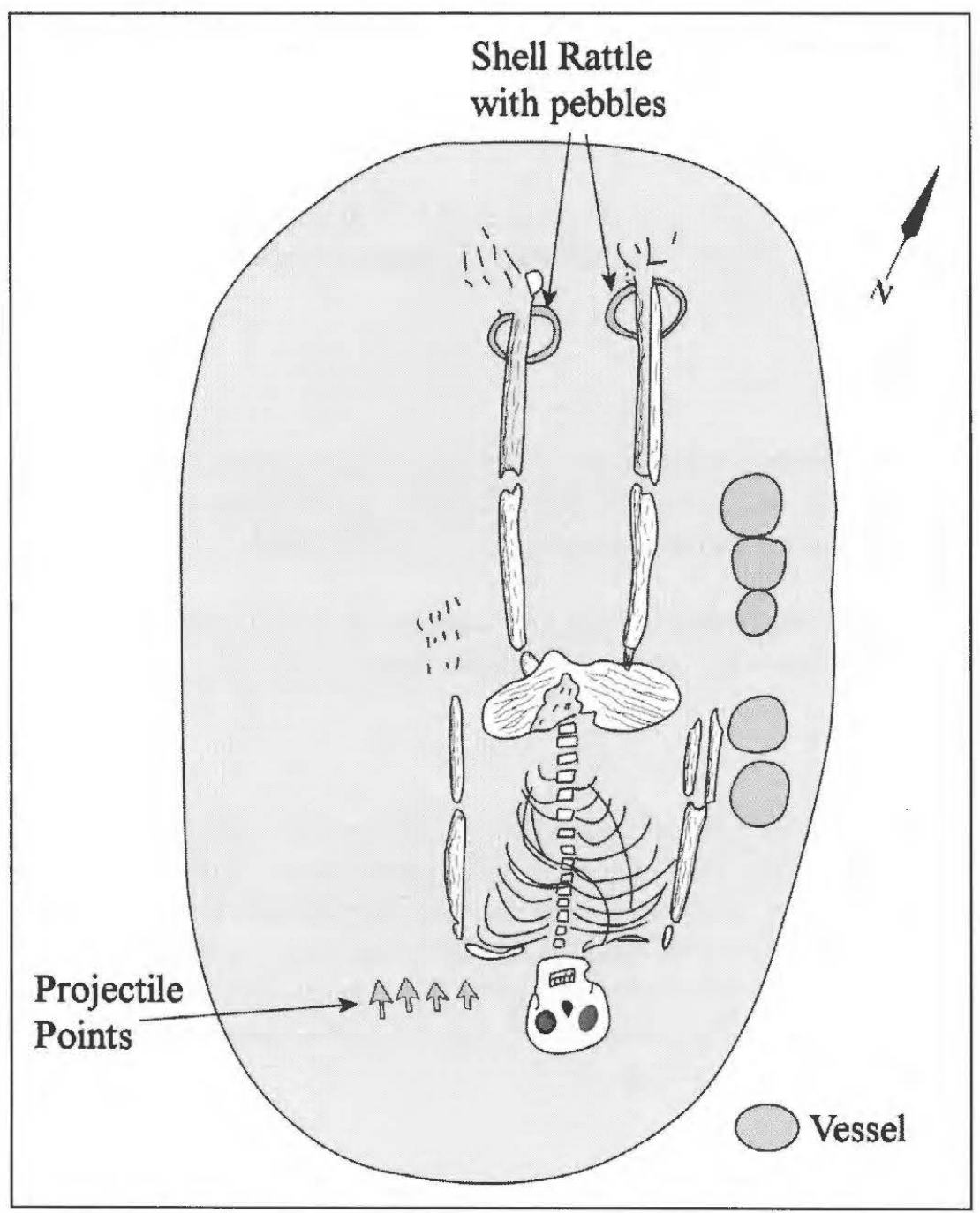

Figure 24. Burial 63 at the Paul Mitchell site. 


\section{Burial 66}

Burial 66 is a 25-30 year old male (Lee 1997:Table 2). This individual has a cranially modeled skull (tabular fronto-vertico-occiptal) (Lee 1997: Table 3), bony spurs on its hands (Lee 1997: Table 4), and evidence of arthritis (Lee 1997:Table 5).

The burial of this individual was excavated in an area of a burned Caddo house, marked by gray ash (99-104 bs), a hard packed or burned red clay ( $84-99 \mathrm{~cm} \mathrm{bs})$, and another zone of gray ash (76-84 $\mathrm{cm} \mathrm{bs).}$ A zone of black sand midden deposits rested above the burned house debris, between $61-76 \mathrm{~cm}$ hs (Wonlsey and Martin 1939:184, 186), and there are more recent alluvial deposits above that.

Funerary offerings with this Caddo male included two bone hair pins by the skull, 12 deer phalanges from the right side of the skull to the right elbow: they may be part of a necklacc, although none of the hones are perforated for stringing. A celt had been placed near the right wrist. A long-stemmed Red River style clay pipe was placed by the left shoulder (Woolsey and 1939:187-188). Three ceramic vessels were placed by the right wrist (this vessel also had animal bones placed inside it), the left foot (a Barkman Engraved vessel), and the lower left leg.

\section{Burial 67}

This shallow and disturbed burial is a 20-25 year old Caddo male (Lee 1997:Table 2). T'his individual has a cranially modeled skull (tabular fronto-vertico-occiptal) (Lee 1997:Table 3). There is also evidence of dental anomalies (Lee 1997:175).

\section{Burial 68}

Burial 68 is a 45-50 year old female (I ee 1997:Table 2). This individual has a cranially modeled skull (tabular fronto-parallelo-occiptal) (Lee 1997:Table 3). This female also had bony spurs on the mandible (Lee 1997:Table 4), and evidence of arthritis (Lee 1997:Table 5).

Funerary offerings with this female consist of two ceranic vessels. One had been placed by the lower right arm and the other was between and just above the knees (Figure 25).

\section{Burial 69}

This is the burial of a Caddo adult of undetermined age and sex. The burial was only partially investigated because of water in the grave, and no skeletal remains were removed from the burial pit, as was also the case for several lunerary offerings: three ceramic vessels and wo mussel shell valves. Sixty-five small conch shell beads were around the neck of the deceased, and a broken long-stemmed Red River style pipe had been placed by the leli shoulder (Figure 26). The two mussel shell valves were above the right shoulder and by the upper left leg. The three ceramic vessels had been placed by the lower left leg; the lower right leg; and the upper right leg.

\section{Burial 70}

This burial feature was identified during the WPA investigations, but it was not excavated beciuse of water in the grave. It was eventually filled in (Woolsey and Martin 1939:195). 

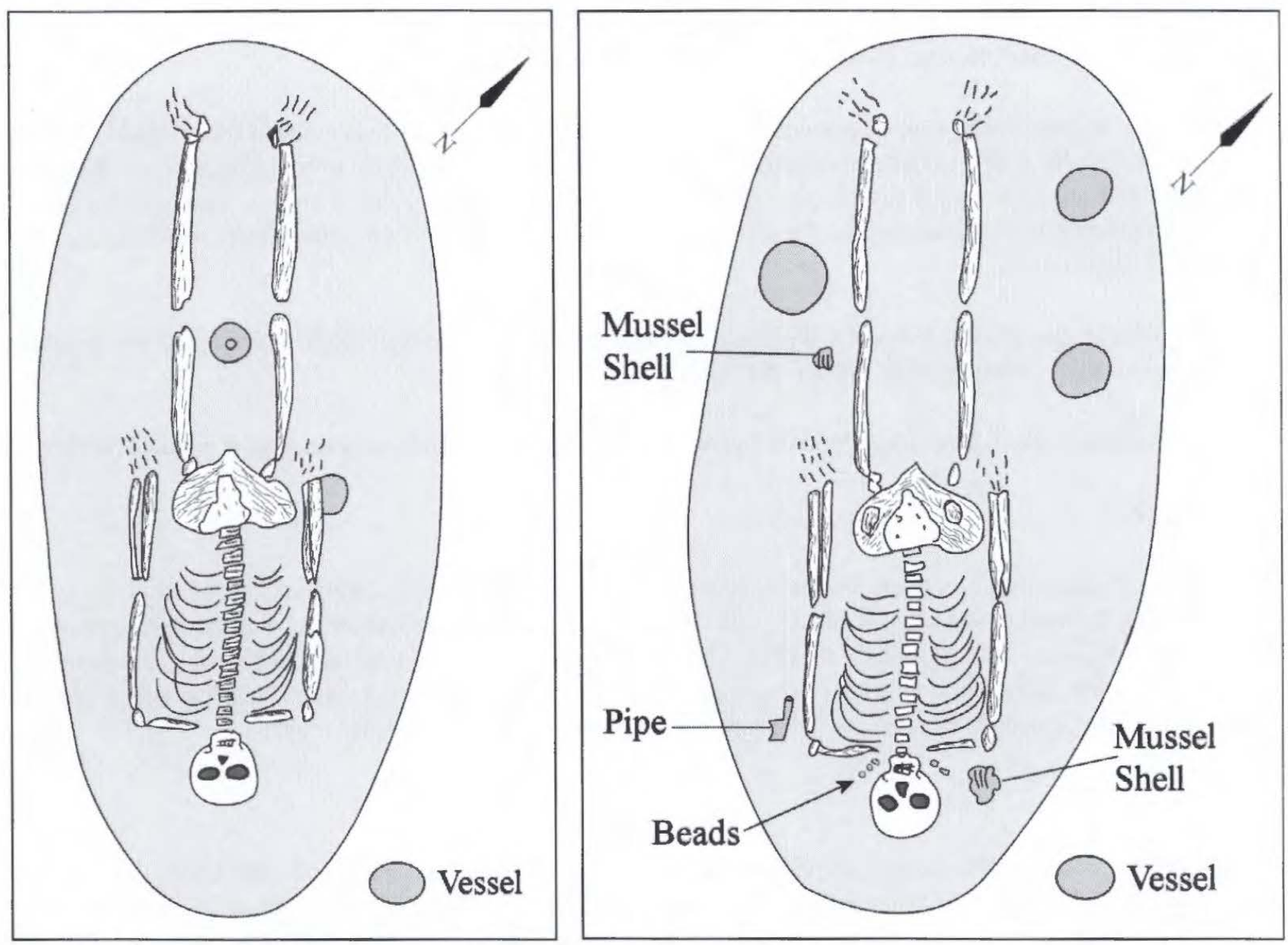

Figure 25. Burial 68 at the Paul Mitchell site. Figure 26. Burial 69 at the Paul Mitchell site.

\section{Bone Pit}

This feature (see Figure 7), $2.43 \times 0.41-0.61 \mathrm{~m}$ in length and width and $25 \mathrm{~cm}$ deep, contained human skeletal remains from a minimum of six individuals (Lee 1997:Table 2). It is likely that these remains represent the remnants of Caddo burials that were reburied on the site after they had been discovered in levee construction (Woolsey and Martin 1939:21). One of the individuals, probably a male, had bony spurs on a tibia (Lee 1997:Table 5).

\section{Habitation Features}

The Mitchell site has both habitation features as well as a large cemetery. The principal habitation feature is a midden deposit on the northern and eastern sides of the cemetery, on the side of the cemetery nearest to McKinney Bayou (see Figure 7).

\section{Midden Deposits by Cemetery}

The principal midden deposit is situated in the northern portion of the area excavated by UT during the WPA investigations, and it is at least ca. $8-13 \mathrm{~m}$ in width and as much as ca. $55 \mathrm{~m}$ in length (see Figure 7). The midden was encountered between $41-46 \mathrm{~cm}$ bs, and is buried by alluvial deposits. It "consists 
of ashes, charcoal, potsherds, bones and shells and flint chips. It is black and greasy looking" (Woolsey and Martin 1939:140); mussel shell hoes were also common in the midden.

Two $3 \times 3 \mathrm{ft}$. test pits were excavated in the midden to sample its artifact content (see Figure 7). The first test pit (Midden No. 1) had two mussel shell hoes, 63 mussel shells, 24 animal bones (deer, birds, and small animals), two snail shells, 72 pottery sherds, 36 lithic flakes, and 45 stones. The Midden No. 2 test pit contained 16 animal bones, 96 pieces of shell, four stones, and 26 pottery sherds (Woolsey and Martin 1939:140-141).

Other finds specifically noted by Woolsey and Martin (1939:143) from the principal midden depr ts include a ceramic spindle whorl and a bone flaking tool.

A second and smaller midden deposit was exposed ca. $6 \mathrm{~m}$ south of the central pi of the cemetery.

\section{Pit Feature}

The pit feature was identified in the northeastern part of the cemetery, along with severi post holes, which led to the staking out of a $60 \times 50 \mathrm{ft}$. section to investigate habitation features, including house sites (Woolsey and Martin 1939:181). The pit, in the southwestern portion of the staked out area. contained ashes, sherds, and charcoal. The exeavations in this area procecded in 6 inch levels (i.e., Level 1, 0-6 inches bs; Level 2, 6-12 inches bs), and all artifacts noted were kcpt by level.

\section{Feature 1}

Feature 1 is a probable hearth, exposed between 24-61 cm bs in Squarc 25L-3 (see Figure 7), and measuring $140 \times 99 \mathrm{~cm}$ east-west and north-south. The feature had a fill of ashes, charcoal, snails, 19 mussel shell fragments, 14 animal bones, and chipped stone flakes, as well as 49 pottery sherds. A tal of six postholes $-13-18 \mathrm{~cm}$ in diameter and $38 \mathrm{~cm}$ in depth - were excavated along the margins of the feature, perhaps as part of a work platform (Woolsey and Martin 1939:197).

\section{Feature 2}

Feature 2 is described by Woolsey and Martin (1939:197-198) as a large ash bed ca. $5.8 \mathrm{~m}$ east-west and $2.9 \mathrm{~m}$ north-south (see Figure 7), whose top surface was identified between $18-30 \mathrm{~cm}$ bs, well above the buried midden deposits; the ash ranged from $2.5-10 \mathrm{~cm}$ in thickness. The ash deposit appears to be part of burned structural debris because it rested on a zone of burned or baked red clay, and there wi six post holes exposed where they penetrated the red clay; these post holes were other $7.6-10.2 \mathrm{~cm}$ in diameter. The structural debris contained many ceramic sherds, chipped stone flakes, mussel shell fragments, and animal bones (including hird bones). Other artifacts recovered in Feature 2 incl led a bone needle fragment, a bone flaking tool, and a deer antler.

\section{Feature 3}

This ash feature is much like Feature 2 (see Figure 7), and likely represcnts the structural debris im a burned wood structure; its extent is not known (Woolsey and Martin 1939:201-202). I1 rea. the ash teature lay at the same depth as the midden deposits, suggesting they were contempora is is part of the site. 


\section{Feature 4}

Feature 4 is a pit ( $107 \times 97 \mathrm{~cm}$ in length and width) in Square 40L-1 (see Figure 7) that was exposed between ca. 10-13 cm bs, and extended to $20-26 \mathrm{~cm}$ bs (Woolsey and Martin 1939:202). The pit fill contained ash, charcoal, and pottery sherds, as well as a bone flaking tool.

\section{Profile Cuts 1-7}

Seven different profiles (see Figure 7) were cut by the WPA in the midden deposits and near cemetery areas at the Mitchell site (Woolsey and Martin 1939:205-211). Profiles in the northern midden deposits (No. 1, 2, 3, 5, and 7) identified buried midden deposits below various sterile alluvial zones. Midden depths are as follows: $86-107 \mathrm{~cm}$ bs (Profile No. 1); 104-119 cm bs (Profile No. 2); 107-120 cm bs (Profile No. 3); 102-122 cm bs (Profile No. 5); and 66-86 cm bs (Profile No. 7), with the midden deposits more deeply buried in the western extent of the investigated site area (Figure 27).

The small area of midden deposits south of the cemetery were investigated in Profile No. 6. These midden deposits are exposed near the surface, from ca. 10-46 cm bs. Profile No. 4 south of the cemetery had no archaeological deposits.

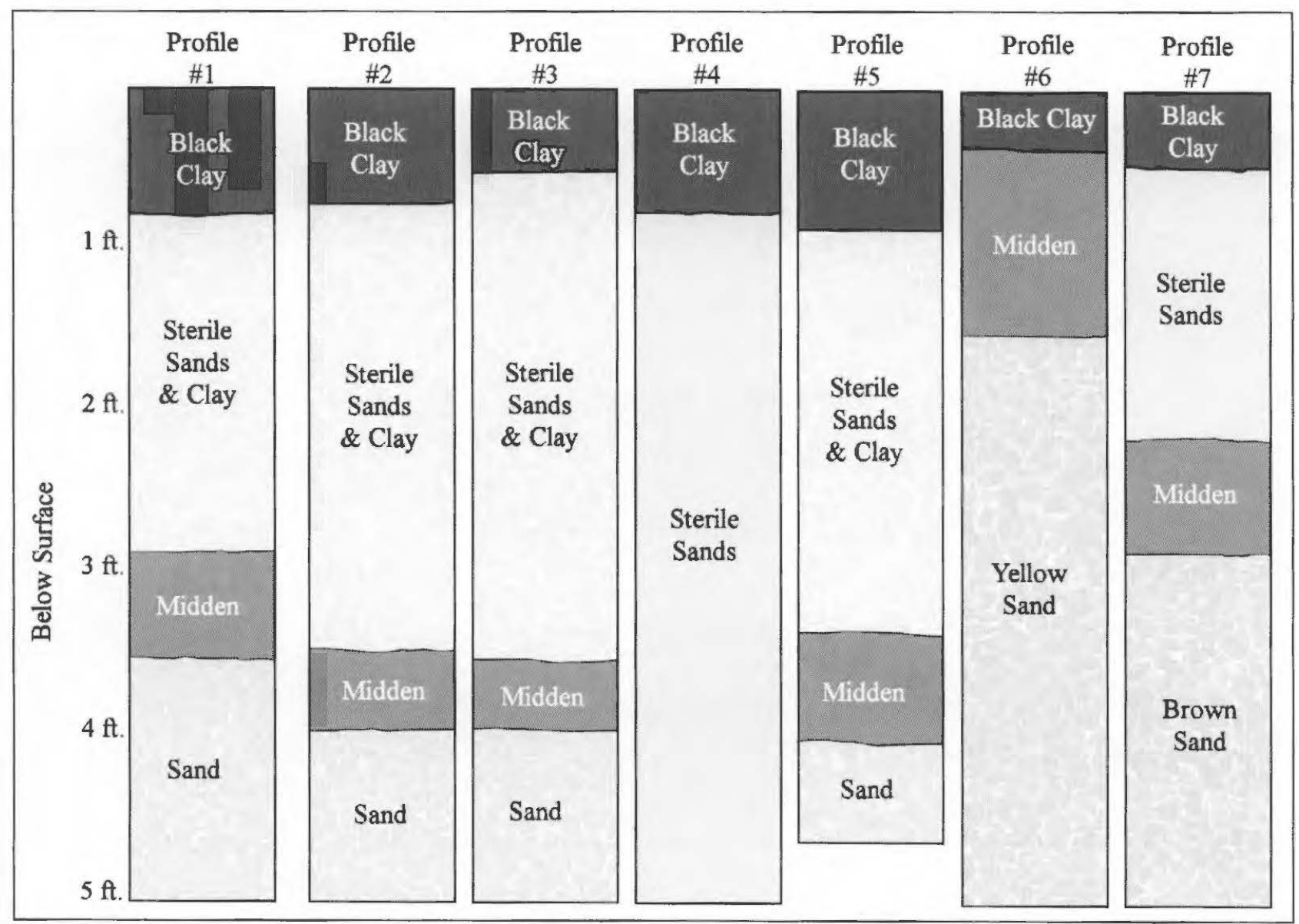

Figure 27. Profiles \#1 to \#7 at the Paul Mitchell site. 


\section{0s Excavations by Pete Miroir}

In March and September 1946, Pete Miroir, a well-known avocational archaeologist from Texarkana, and Babe Henson, investigated a large area $(80 \mathrm{x} 90 \mathrm{ft}$.) at the western end of the Mitchell site cemetery (Miroir 1946) (see Figure 7). During this work, three ancestral Caddo burials were identified and excavated by Miroir (Figure 28).

Miroir's Burial 1 was that of an adult placed in an extended supine position in a pit $(2.39 \times 1.09 \mathrm{~m}$ in length and width) whose base lay at $94 \mathrm{~cm}$ bs. Funerary offerings consisted of two ceramic vessels placed by the left and right shoulders and a celt. Miroir's Burial 2 was also an adult, in a $1.32 \mathrm{~m}$ deep pit. Funerary offerings included five ceramic vessels on both sides of the body, two ceramic ear spools at the back of the head and on the shoulders (Figure 29), and a long-stemmed Red River pipe had been placed near the right shoulder. The long-stemmed pipe funerary offering suggests that this burial dates to sometime

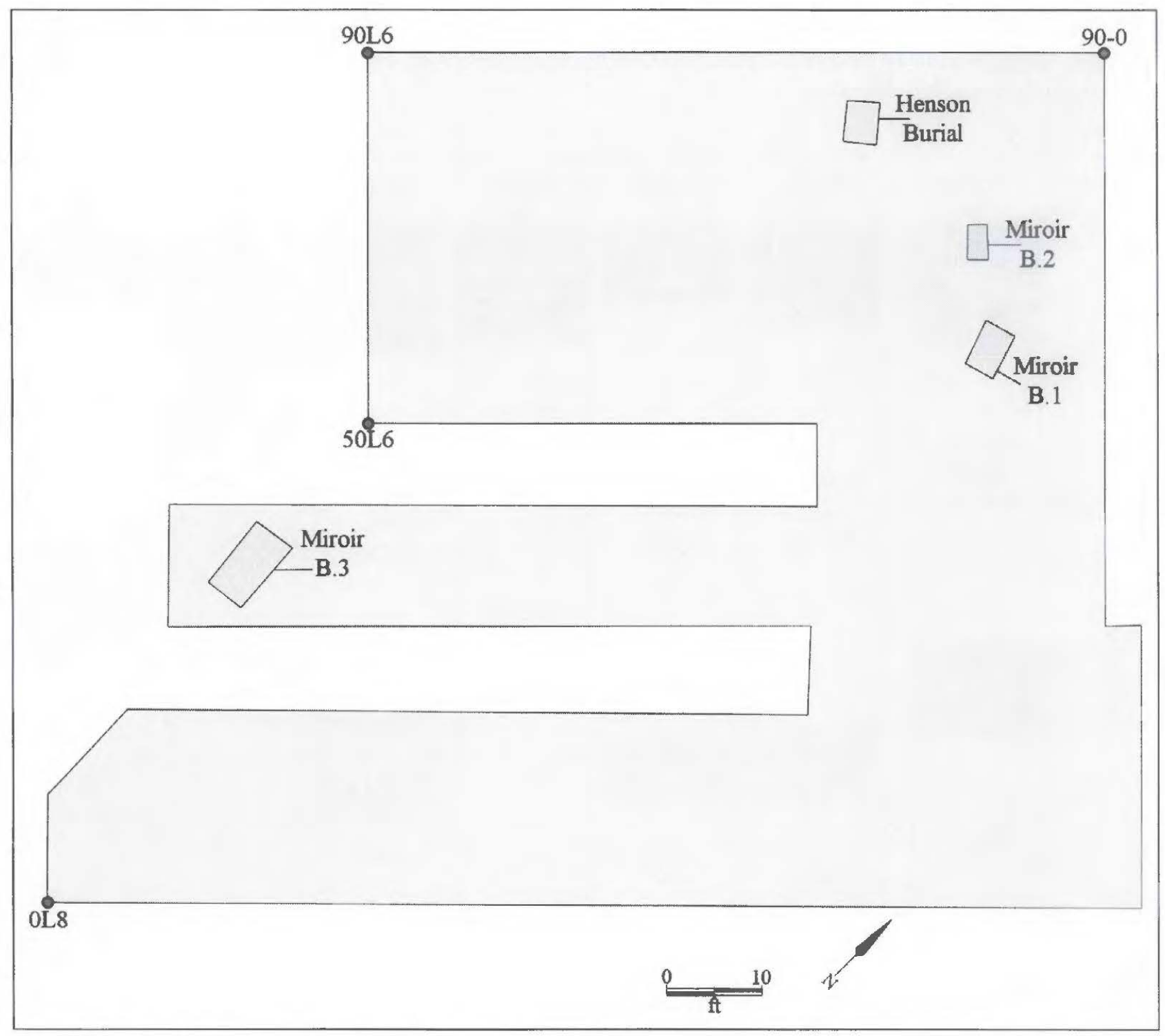

Figure 28. Miroir's 1946 excavations at the Mitchell site. 


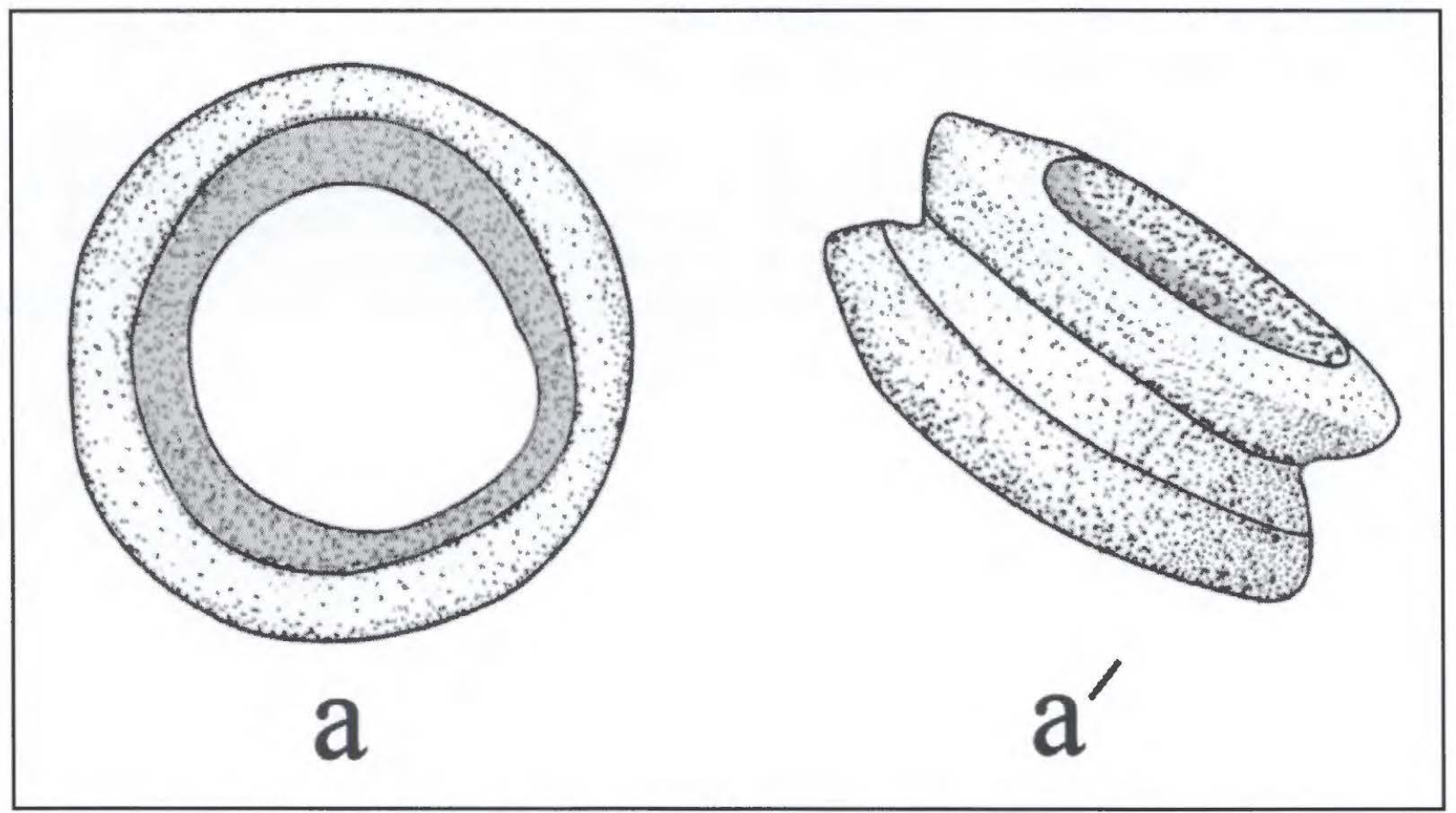

Figure 29. Ceramic ear spool from Miroir's Burial 1 at the Paul Mitchell site.

prior to A.D. 1400 (cf. Hoffman 1967). Miroir's Burial 3 was that of an adult, placed in a $1.37 \mathrm{~m}$ deep grave. Funerary offerings included five ceramic vessels above the left shoulder and head, and by the right arm, and a cache of bone tools placed by the right forearm, including a sharpened antler, two deer ulna flaking tools, and several deer long bones.

Vessels recovered by Miroir (the collections are in the University of Arkansas Museum in Fayetteville, Arkansas, but drawings of the vessels are discussed below) from these Caddo burials include the following: (a) Pease Brushed-Incised jars $(n=2)$; (b) engraved bottles with concentric circle elements, likely of the Hatchel Engraved type ( $n=2)$; (c) Barkman Engraved carinated bowls $(n=3)$; (d) Bowie Engraved carinated bowls $(n=2)$; (e) a Nash Neck Banded jar (=1); (f) a Glassell Engraved carinated bowl $(\mathrm{n}=1)$; $(\mathrm{g})$ a Hatchel Engraved bottle $(\mathrm{n}=1)$; and $(\mathrm{h})$ a Moore Noded bowl $(\mathrm{n}=1)$. The three burials have 13 ceramic vessels as funerary offerings, an average of 4.3 vessels per burial. The stylistic character of these vessels are consistent with the notion that these burials date to the early part of the Late Caddo period, from ca. A.D. 1400-1500, and perhaps even later.

The one burial excavated by Henson (see Figure 28) had two associated funerary offerings. The first is a large and deep bowl with concentric semi-circles on the vessel body and cross-hatched diagonal engraved lines on the tall rim panel and a Taylor Engraved bottle.

\section{Archaeological Investigations}

In advance of the development of a loop levee and alternate diversion channel for the existing Bowie County Levee, as well as a widening of the existing levee, Cliff et al. (1997) conducted an archaeological survey in the area of the Mitchell site. In the survey, a buried midden deposit (ca. $100 \mathrm{~cm}$ bs) was noted in the southern bank of McKinney Bayou, in an area directly north of the UT/WPA excavations (see Figure 2; see also Cliff et al. 1997:Figure 12); the midden contained charcoal, ash, animal bone, lithic debris, 
and mussel shell. One shovel test on this part of the site also encountered the midden deposits, burie from ca. $60-100+\mathrm{cm}$ bs. Charcoal and mussel shell were preserved in the midden.

One shovel test (ST 6) excavated on the southern sidc of the diversion canal (see Cli et al. 1997). just southeast of the UT/WPA excavations (sec Figure 2) encountered a thick deposit of daub and bak clay from $40-60+\mathrm{cm}$ bs, indicating that a burned Caddo structure is preserved in this area. The shovel test contained 383 pieces of daub and burned clay, two pieces of lithic debris, seven grog-tempered ceramic sherds (including two possible Barkman Engraved body sherds). charcoal, burned animal bone, and musiel shell fragments. 


\section{CHAPTER 3, MATERIAL CULTURE REMAINS}

\section{Ceramic Vessels}

The discussion of the ceramic vessels from the Mitchell site includes one vessel recovered by Jackson in 1932, 59 from the W. H. Mathews excavations in 1935, 110 vessels from the 1938-1939 WPA excavations, and 13 vessels from the 1946 excavations by Pete Miroir. The total vessel sample from these various investigations is 183 in number. In some cases, the character of the vessels is assessed from old drawings or photographs only, while other assessments are based on notes and drawings on file at TARL, plus recently obtained photographs taken by Laura Nightengale of TARL.

One drawback to the analysis of the vessels from the Mitchell site at TARL is that none of them have been physically documented (i.e., no characterization of size, rim-lip form, surface treatment, temper, firing) or details of the design elements obtained because access to these vessels, all subject to the provisions of the Native American Graves Protection and Repatriation Act, has not been obtained from the Caddo Nation of Oklahoma. As of this writing (May 2014), access to this NAGPRA collection of vessels could not be obtained from the Caddo Nation's Cultural Preservation Program because all functions of the Caddo Nation have been put on hold because of disputes and law suits between rival factions of the Caddo Nation of Oklahoma that began September 25, 2013; these disputes and law suits have not been resolved to date.

Based on the photographs and vessel descriptions in Sorrow (1968), the following ceramic types are present in the Mitchell site assemblage, beginning with the utility wares $(n=47)$ :

- $\quad$ cf. Emory Punctated jars $(n=2)$

- McKinney Plain jars $(n=5)$

- Maydelle Incised jar $(n=3)$

- Moore Noded bowls $(n=7)$

- Nash Neck Banded jars $(n=19)$

- Pease Brushed-Incised jars $(\mathrm{n}=5)$

The predominant utility ware is Nash Neck Banded (40.3 percent), followed by Moore Noded (14.9 percent), McKinney Plain (10.6 percent), and Pease Brushed-Incised (10.6 percent). Overall, the utility wares comprise 34 percent of the TARL mortuary vessel assemblage from the Mitchell site.

Unidentified utility ware vessels include two jars with appliqued triangles and clusters of nodes, and a third jar with incised triangles filled with brushing (see Sorrow 1968:Plate 10h). Another jar has fingernail punctates covering the vessel body; the rim is missing. One carinated bowl has horizontal incised lines on the rim panel (see Sorrow 1968:Plate 12a), and another has incised triangles filled with diagonal incised lines.

The fine ware vessels ( $n=86$, and 63 percent of the TARL assemblage) from Mitchell are:

- Avery Engraved deep bowl $(n=1)$, carinated bowl $(n=1)$, and jar $(n=1)$

- Barkman Engraved carinated bowls $(n=15)$ and deep bowls $(n=2)$

- Belcher Engraved bottle $(n=1)$

- Bowie Engraved carinated bowls $(n=7)$

- Friendship Engraved bottles $(n=2)$ and carinated bowl $(n=1)$

- Haley Engraved bottles $(n=3)$ and deep bowl $(n=1)$ 
- Hatchel Engraved bottles $(n=15)$

- Hempstead Engraved bottle $(n=1)$ and carinated bowls $(n=2)$

- Hickory Engraved bottles ( $\mathrm{n}=5$ ), including one Hickory Engraved, var. East bottle (Bohannon 1973:47 and Figure 6i), and bowls $(n=2)$

- Means Engraved carinated bowl $(n=1)$

- Simms Engraved carinated bowl $(\mathrm{n}=1)$

- Taylor Engraved bottles $(n=3)$ and jar $(n=1)$

Unidentified fine wares from the Mitchell site include a red-slipped bowl and two carinated bowls with horizontal and/or zig-zag lines (see Sorrow 1968:Plate 12h). Three carinated bowls have triangle elements (see Sorrow 1968:Plate 11h), and there are also two engraved effigy bowls. Two small bowls/ carinated bowls have very faint engraved designs, and a third has horizontal and diagonal engraved lines. Another carinated bowl has both horizontal and cross-hatched engraved elements, and a second carinated bowl has both horizontal lines and hatched engraved ladder elements.

There are also two small bottles with diagonal engraved lines as well as horizontal lines encircling the base of the neck, a third bottle with triangles and small concentric circles (see Sorrow 1968:Plate 7b), and a fourth bottle with engraved circles. Another bottle may have a single incised line at the base of the neck (Sorrow 1968:19 and Plate 8c), and on another bottle the design method/elements cannot be determined. There is also a bottle with horizontal lines below the neck and vertical engraved lines on the body.

The principal fine wares in the Mitchell site cemetery are Barkman Engraved (20 percent), Hatchel Engraved (17.4 percent), Bowie Engraved ( 8 percent), and Hickory Engraved ( 8 percent). As will be discussed below in more detail, the earliest use of the cemetery by ancestral Caddo peoples is marked by ceramic vessels ( $n=18,61$ percent bottles) of the Friendship Engraved, Haley Engraved, Hempstead Engraved, Hickory Engraved, and Means Engraved types placed in burial features as funerary offerings. The remainder of the typologically identifiable fine wares ( $n=48,40$ percent bottles) are from later Texarkana phase burials in the Mitchell site cemetery.

There are also two plain ware bottles and two plain bowls in the vessel assemblage. The plain wares account for only 3 percent of the mortuary vessels from the Mitchell site in the TARL sample.

\section{Ceramic Vessel Sets}

There are distinctive sets of associated vessels that had been placed together in burials at the Mitchell cemetery. These form the basis of a provisional seriation of the burials (cf. Creel 1991; Perttula 1992), one that needs to be substantiated by the radiocarbon dating of organic remains from a series of the burial features at the site, as well as from burial features at the nearby and generally contemporaneous Eli Moores (41BW2) and Hatchel (41BW3) sites.

\section{Seriation of Ceramic Vessels}

A principal hindrance to the development of a seriation of ceramic vessels from burials at the Mitchell site is the fact that many of the burials $(n=25)$ excavated by the WPA had been previously disturbed and funerary offerings (including ceramic vessels) removed (Figure 30). These burials are distributed across all parts of the WPA-excavated area. Nevertheless, there is sufficient information available from the remaining burial features to construct an occurrence seriation (see O'Brien and Lyman 1999:119-121) of vessel sets, thus providing an initial view of the 200-300+ year temporal history of the ceramic vessels placed as funerary offerings in ancestral Caddo burial features at the Mitchell site. 


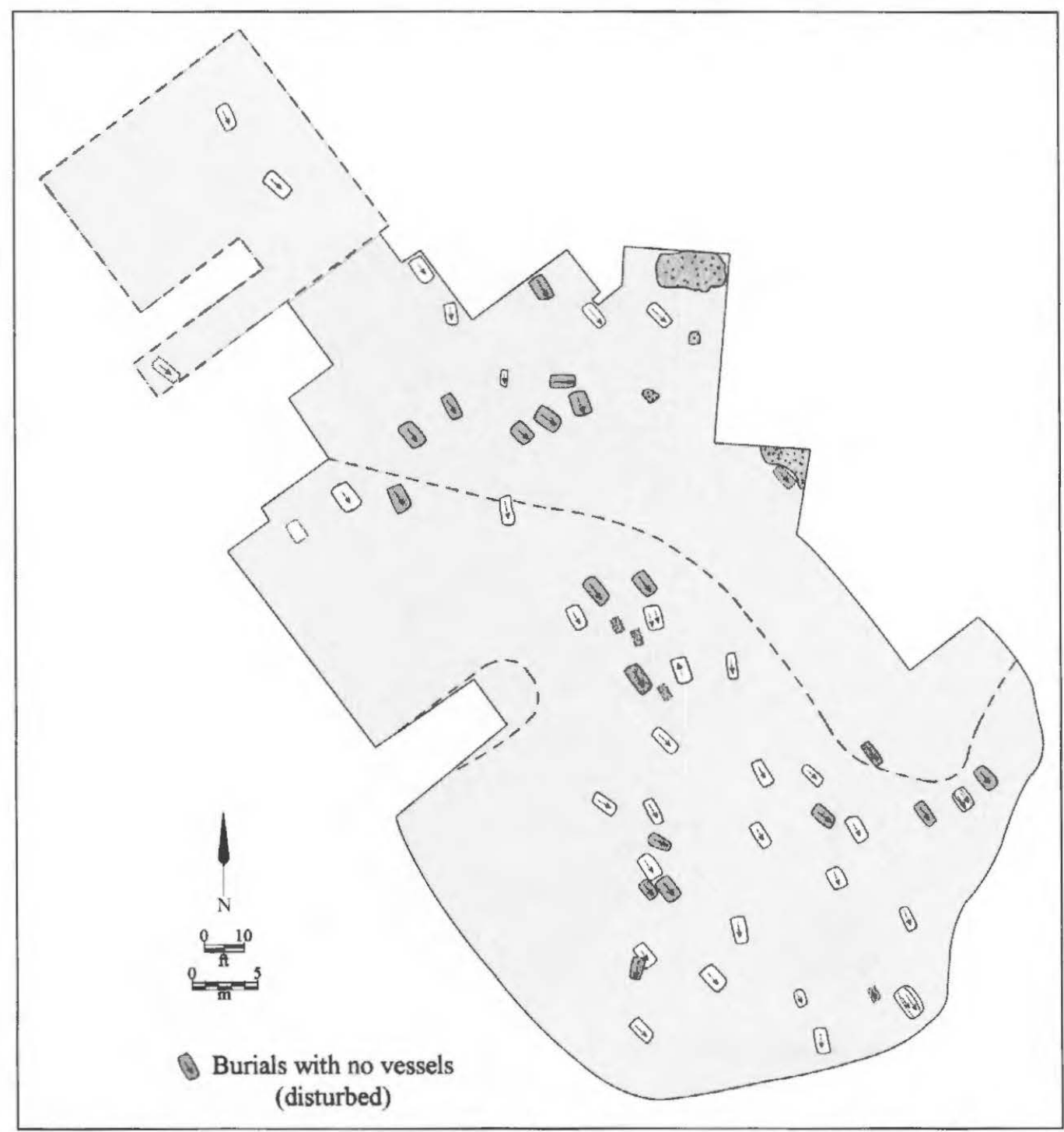

Figure 30. Burials with no vessels at the Mitchell site.

\section{ca.A.D. $1200-1400$}

Middle Caddo period burials in the Mitchell site cemetery occur primarily in the northern part of the cemetery (Figure 31), and include burials excavated by Jackson, Mathews, Miroir, and the WPA archaeologists. This includes Burial K-2 (Jackson 1932), Burial MV-1 (Martin 1936), M-B2 and M-B3 (Miroir 1946), Mathews (1935) burials 1-3, 5-10,13, and 21, and seven WPA burials (Figure 31).

Ceramic vessels placed in these earlier burials include the fine wares Haley Engraved (Figures 32 and 33b; see also Suhm and Jelks 1962:Plate 31f), Hickory Engraved (Figures 33a, 34d, and 35a), Hempstead Engraved, Friendship Engraved, and Means Engraved (Figure 34a), along with untyped engraved fine wares (Figures 34b, 36c, 37, 388a, 39, 40a) with rectangular, curvilinear, and horizontal elements on carinated bowls as well as vertical engraved elements (Figure $41 \mathrm{~b}$ ) and horizontal-curvilinear-and triangular elements (Figure $35 \mathrm{~b}$ ) on bottles. Utility wares include cf. Dunkin Incised jars as well as incised-punctated vessels (Figures $38 \mathrm{~b}$ and $40 \mathrm{~b}$ ), Pease Brushed-Incised jars (Figures $35 \mathrm{c}$ and $41 \mathrm{a}$ ), incised (Figure 36a), incisedpunctated-appliqued (Figure 36b), and punctated-appliqued (Figure 34e) vessels. A few jars have handles. 


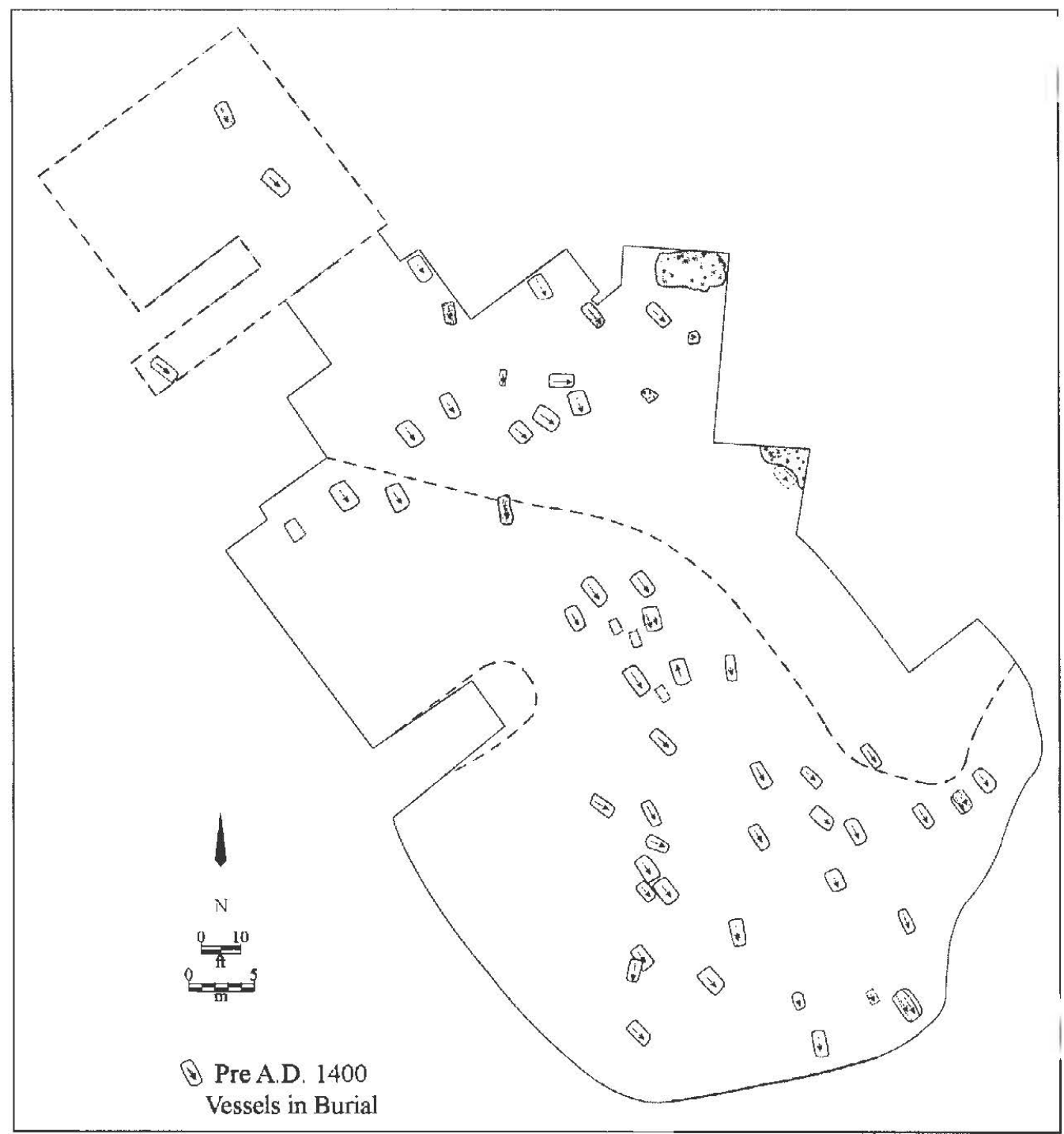

Figure 31. Burials with ca.A.D. 1200-1400 vessels in the Mitchell site cemetery.

There are also plain ware bowls (Figure 42a-b), bottles (see Figure 38c), and jars (see Figure 34c) included as funerary offerings in these ca. A.D. 1200-1400 burial features.

Burial M-B2 excavated by Pete Miroir in 1946 includes two Pease Brushed-Incised ja ( $F^{*}$ sure 43a, g) and three carinated bowls, two probably of the Barkman Engraved type (Figure 43d-e), and the other an unidentified type (Figure 43f). In Burial M-B3 are Friendship Engraved bottles and carinated bowls (Figure 43i-j), an unidentified bottle with curvilinear scrolls and negative S-elements (Figure 43k), and an engraved deep bowl (Figure 431).

\section{A.D. $1400-1550$}

Barkman Engraved vessels in 10 different burials are found in the same areas (Figure 44) as $\mathrm{p}^{r} \quad$ I.D. 1400 burial vessels as well as later Texarkana phase burials (see below). This suggests that Barkman Engraved is a stylistically transitional fine ware whose origins lie with pre-A.D. 1400 fine wares (i.e., Handy Engraved), and a fine ware that was replaced by Simms Engraved around ca. A.D. 1550. 


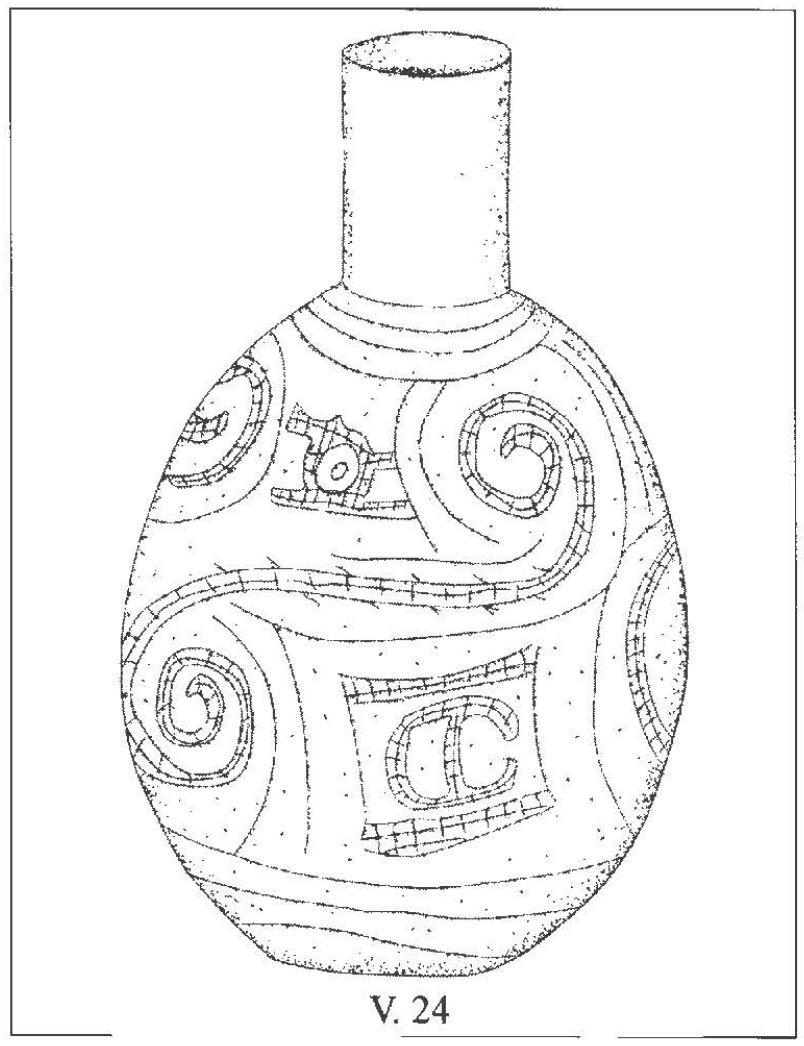

Figure 32. Haley Engraved bottle from Burial 6 excavated by Mathews at the Mitchell cemetery.

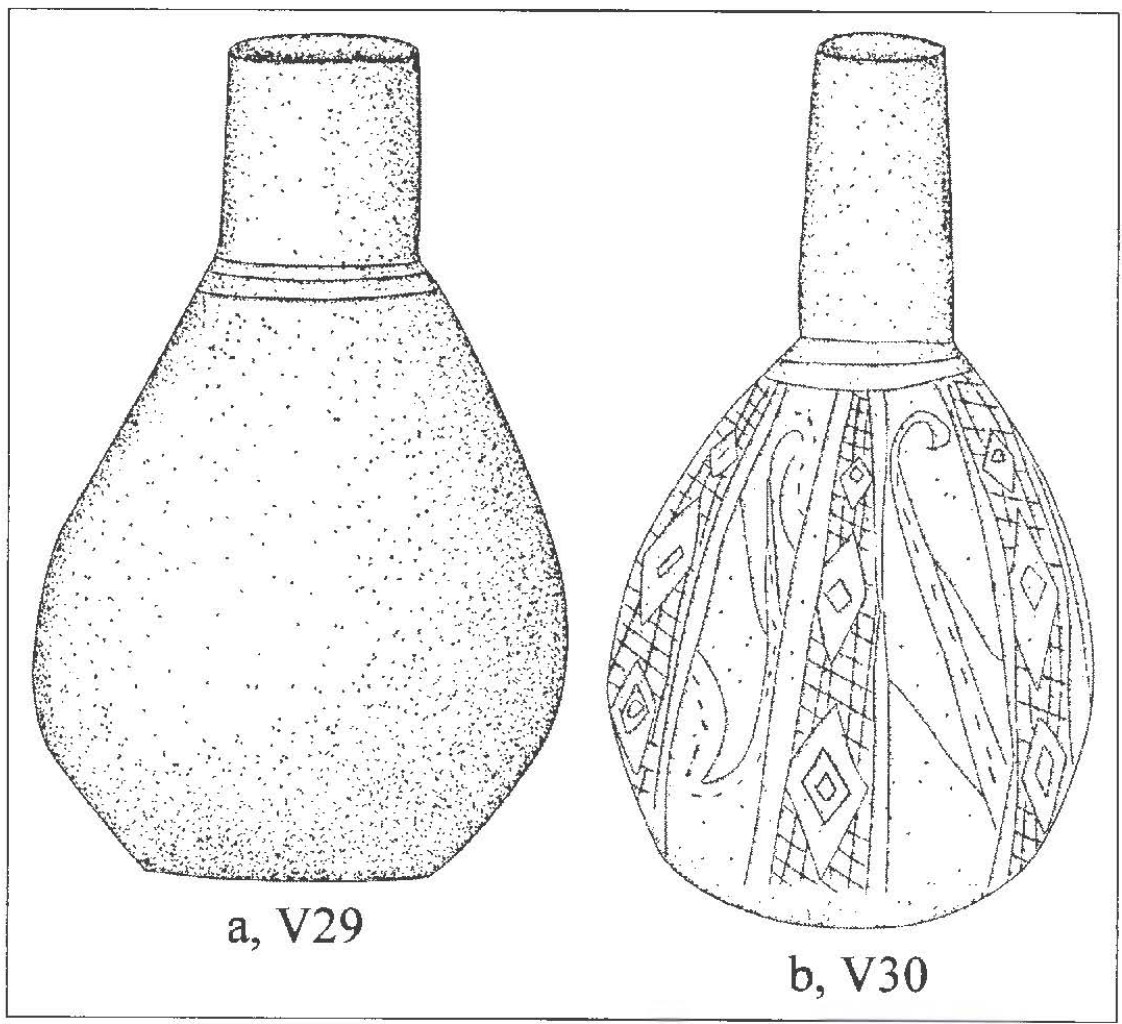

Figure 33. Engraved bottles from Burial 9 excavated by Mathews. 


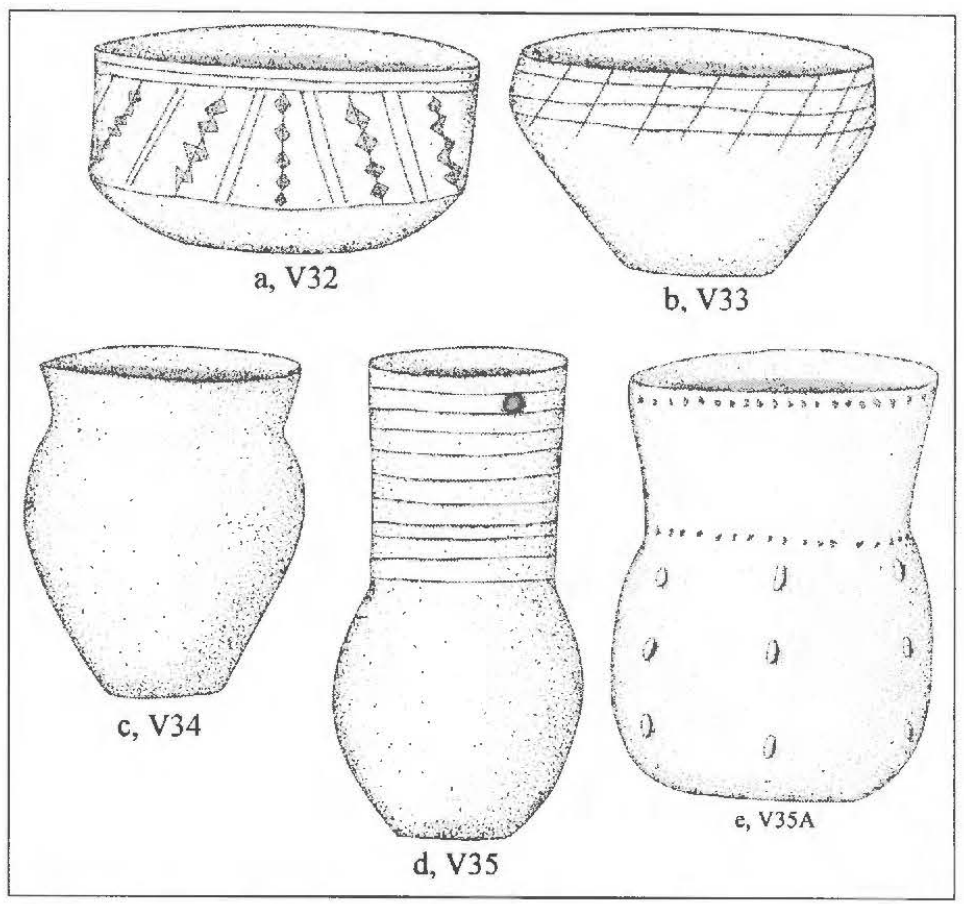

Figure 34. Burial 10-Mathews vessels.

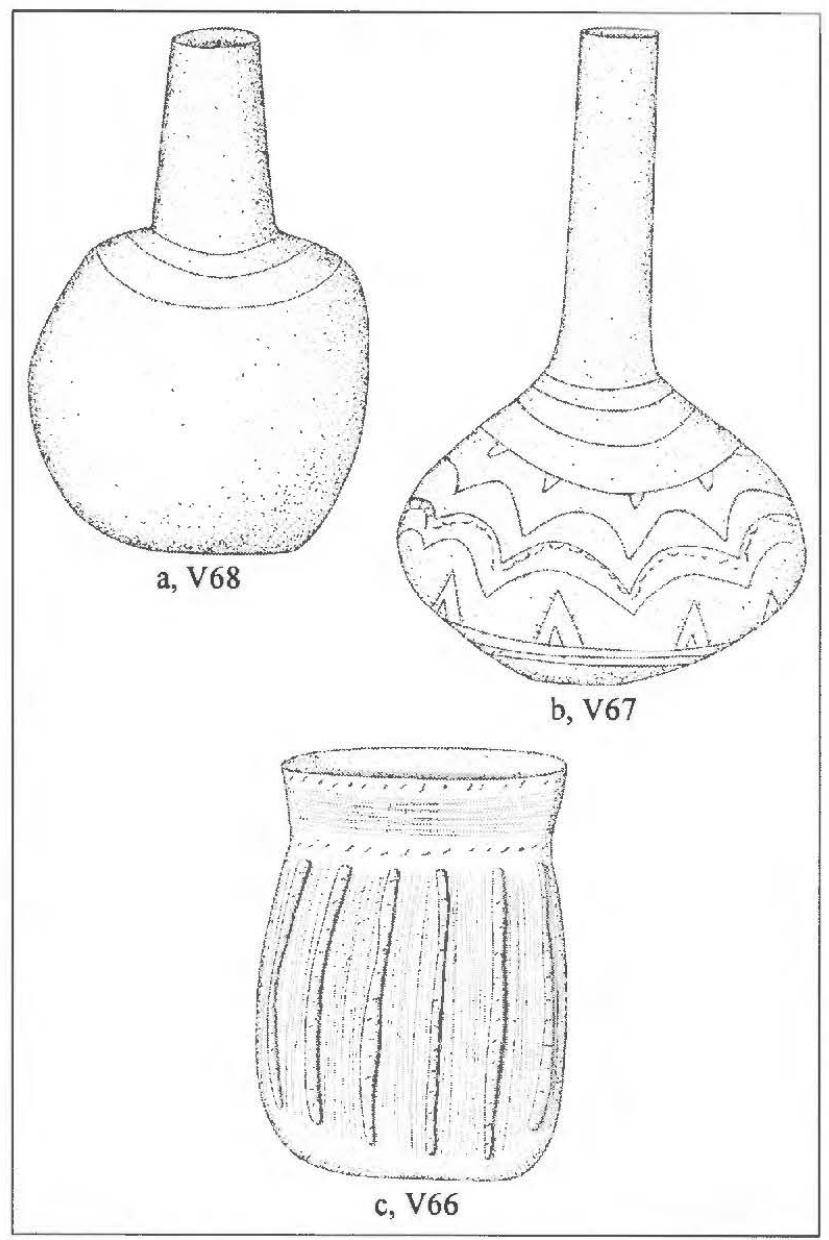

Figure 35. Burial 21-Mathews vessels. 


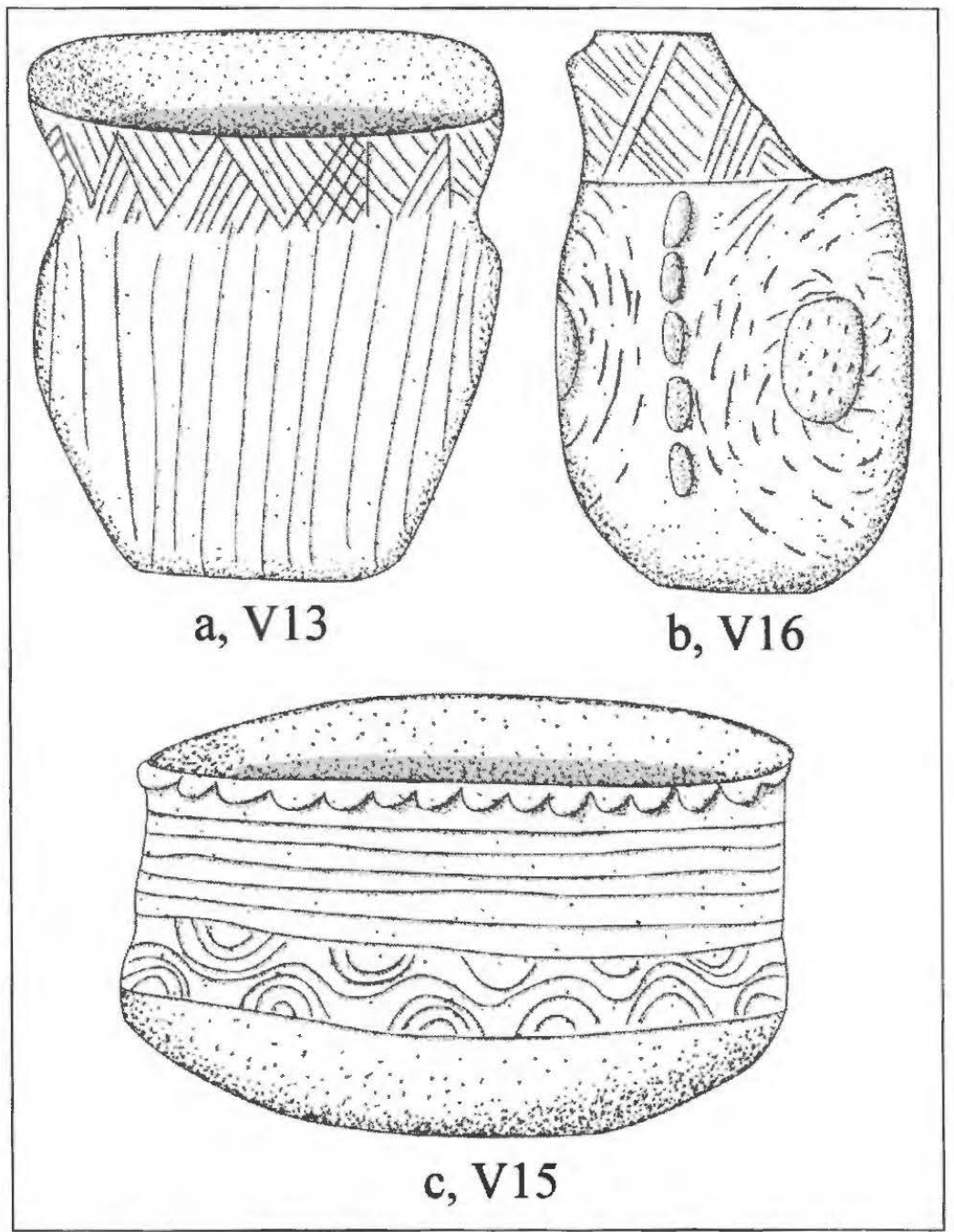

Figure 36. Vessels from Burial 1 excavated by Mathews (1935).

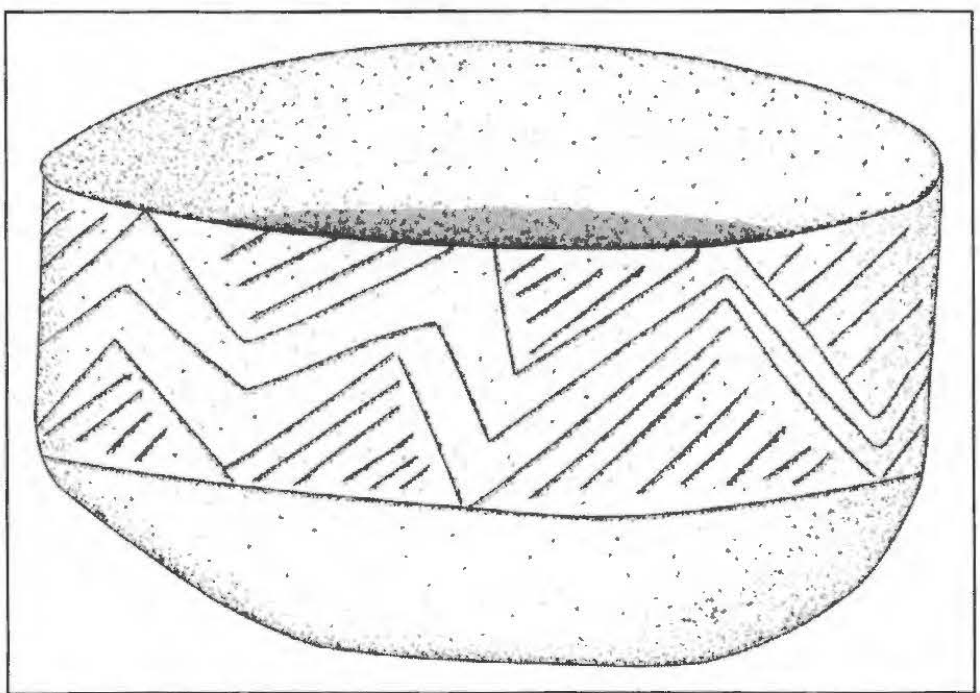

Figure 37. Burial 3-Mathews vessel. 


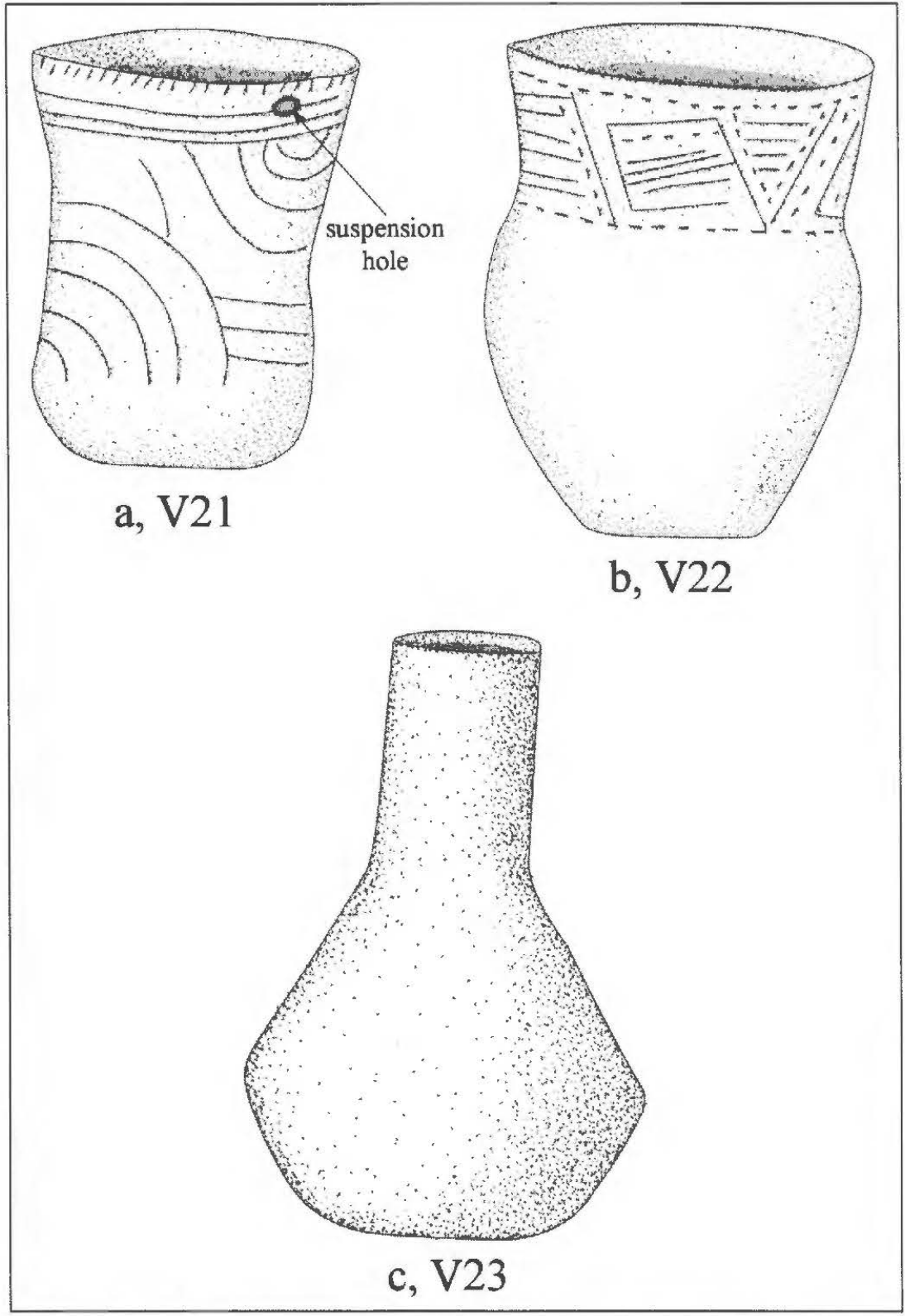

Figure 38. Burial 5-Mathews vessels.

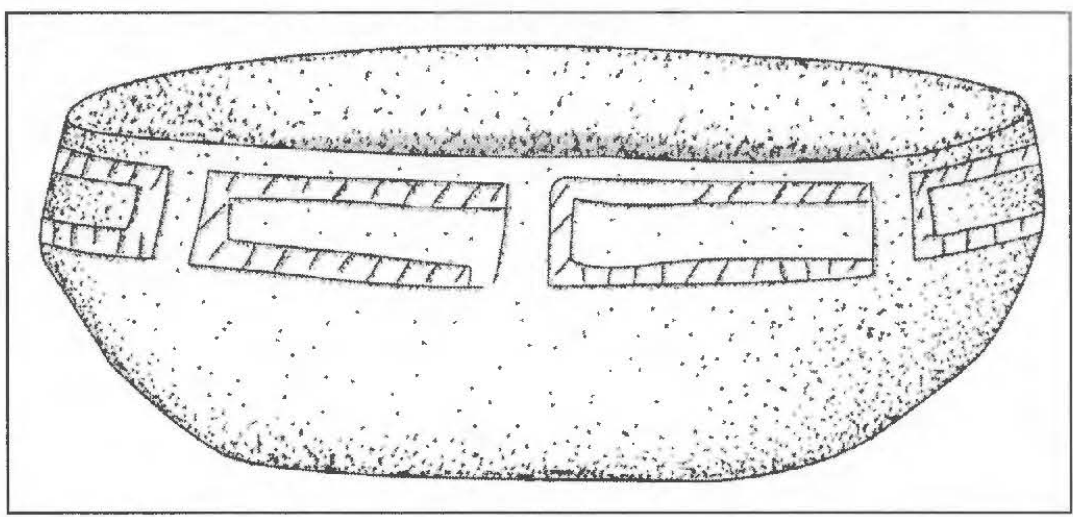

Figure 39. Burial 7-Mathews vessel. 


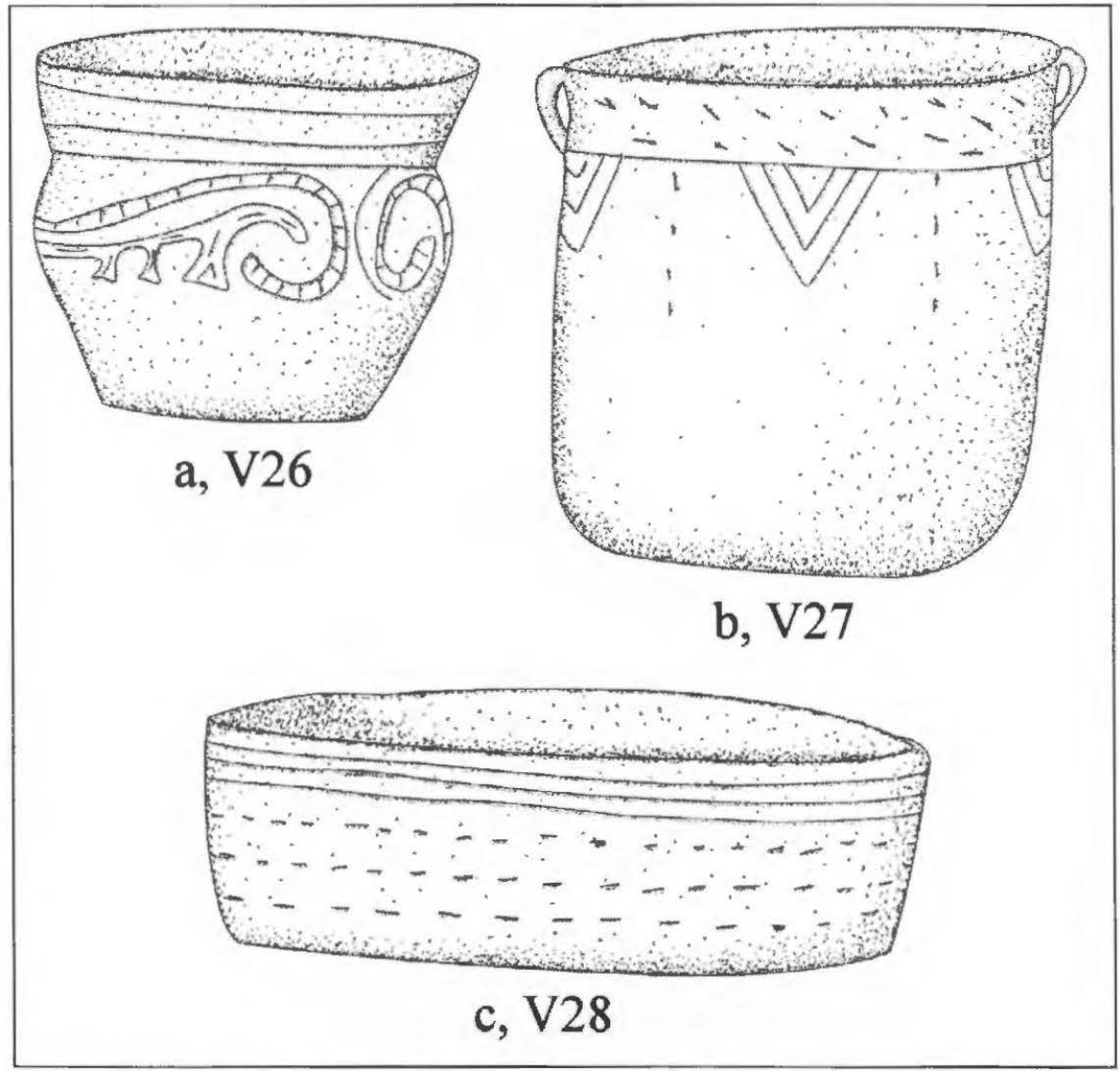

Figure 40. Burial 8-Mathews vessels.

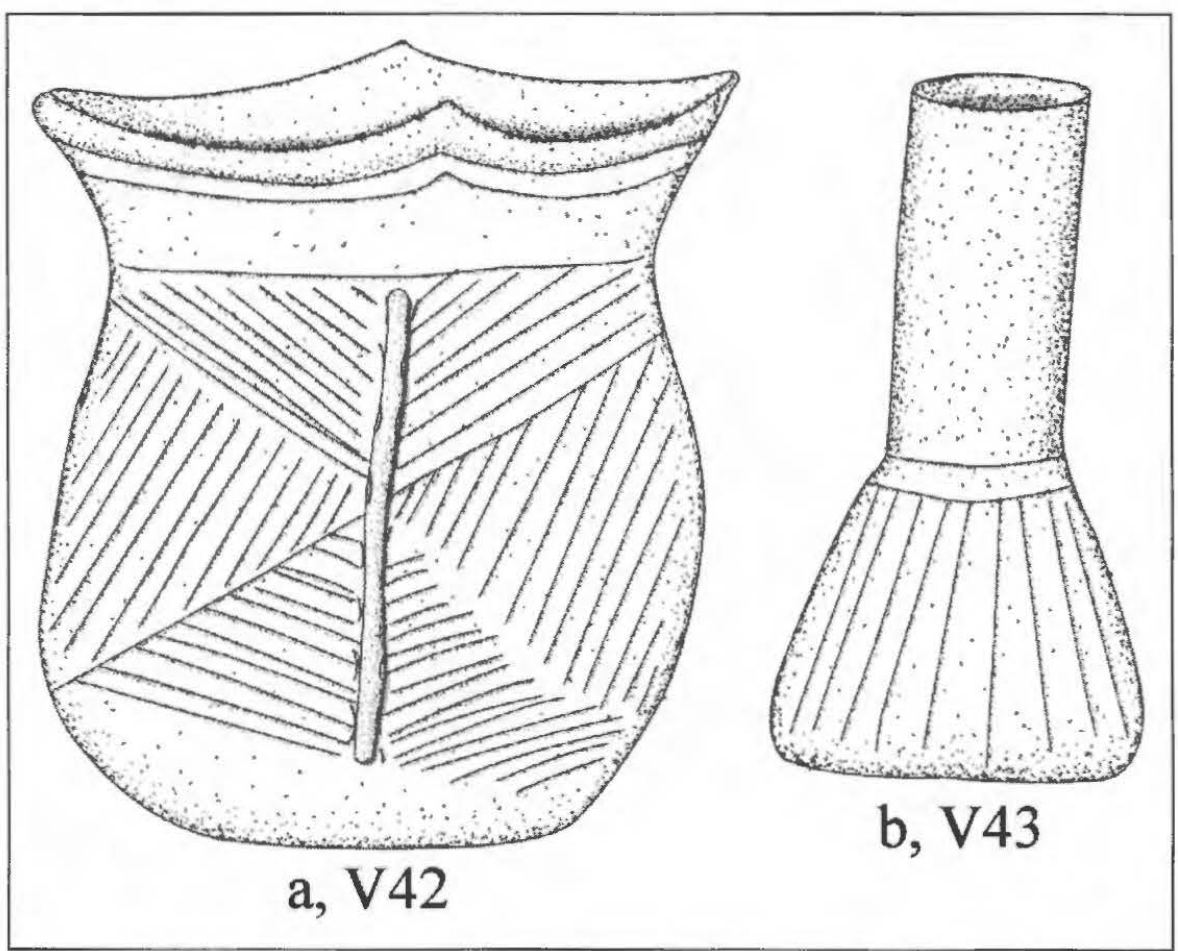

Figure 41. Burial 13-Mathews vessels. 


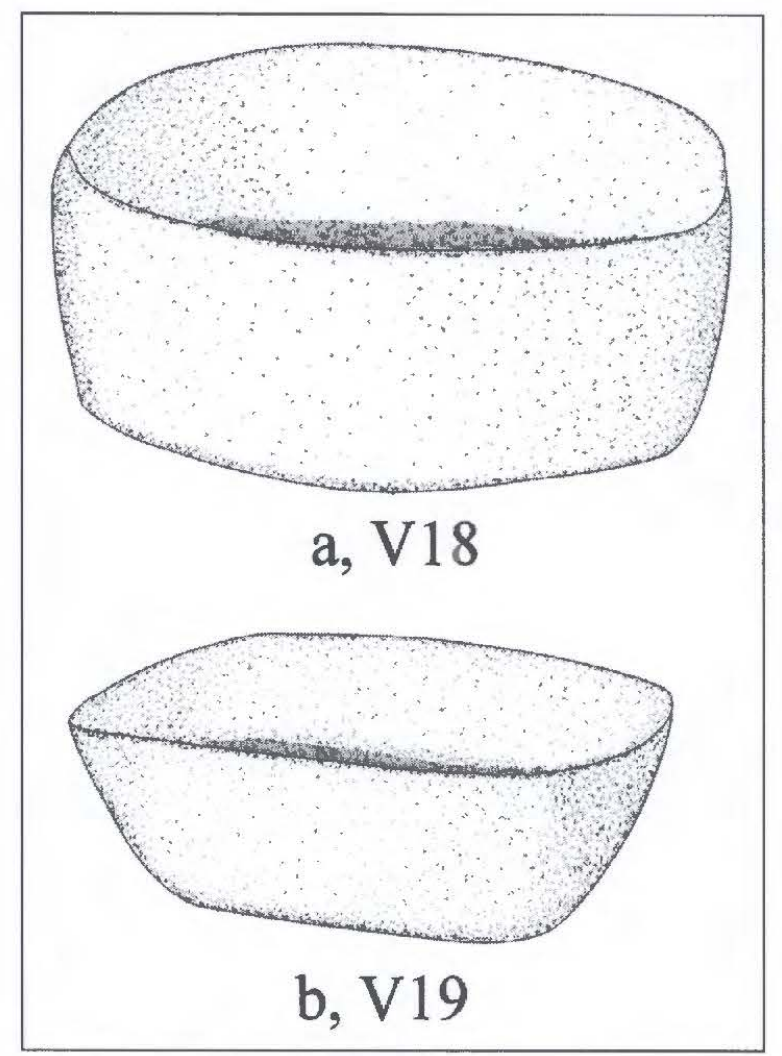

Figure 42. Burial 2-Mathews vessels.
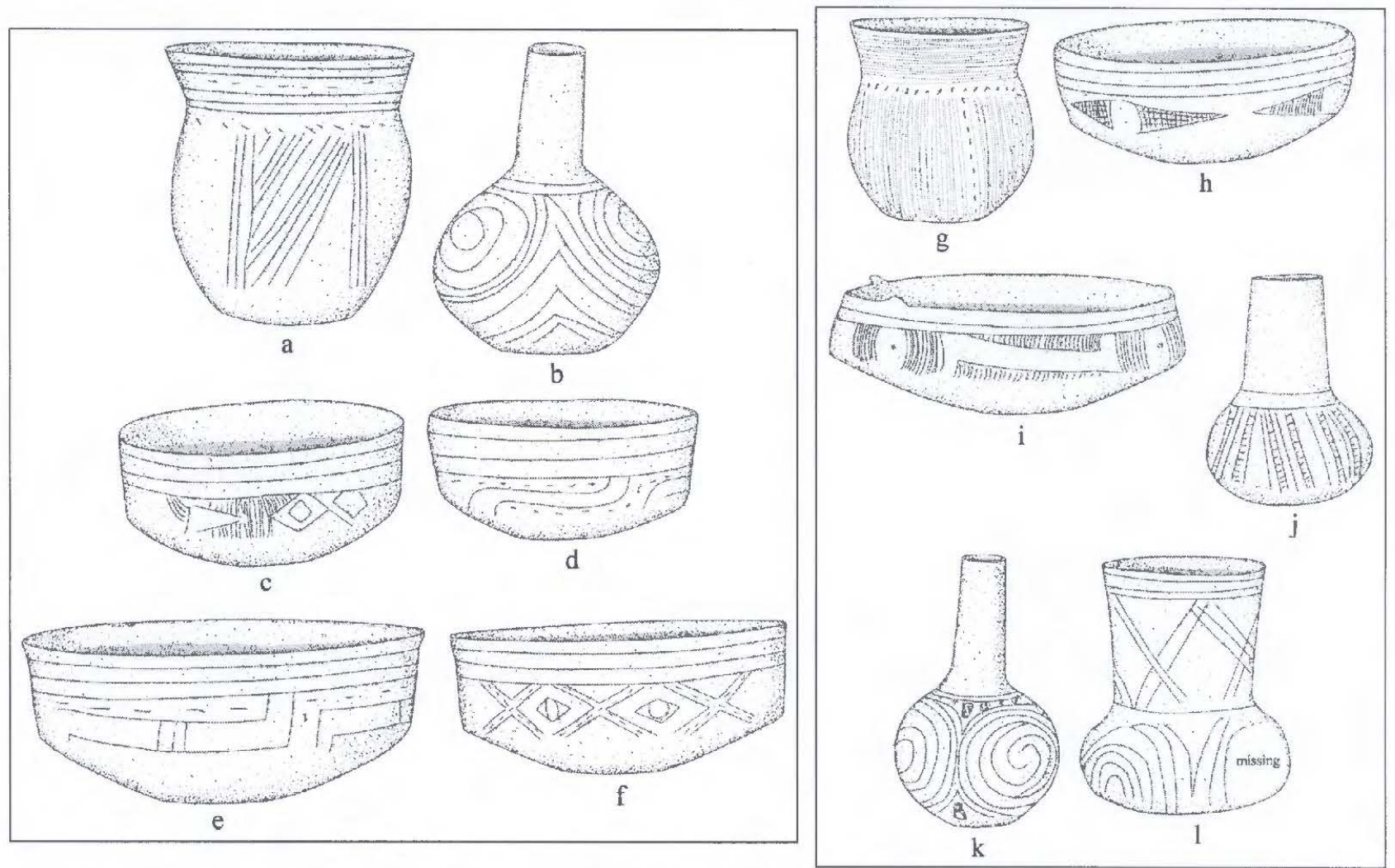

Figure 43. Vessels from Burials 1-3 excavated by Pete Miroir in 1946 in the Mitchell site cemetery: a, d-g, Burial 2; b-c, Burial 1; h-l, Burial 3. 
Early Texarkana phase (ca. A.D. 1400-1550) ceramic vessels certainly include vessels of the types Barkman Engraved (Figures 45a, 46a, 47d, and 48b; see also Figure 43d-e), as well as Bowie Engraved (see Figure 43c, h), and Hatchel Engraved (Figures 46b, 47f, 49a, and 50b) and Avery Engraved compound bowls with flaring rims. The utility wares include the McKinney Plain, Moore Noded (Figures 47e and 51b), Nash Neck Banded (Figures 47b-c and 51a), Pease Brushed-Incised (Figure 49b), and Foster Trailed-Incised types (Creel 1991; Perttula 1992:125), as well as brushed-punctated jars (Figure 50c) and a punctated-appliqued jar with handles (Figure 48a). The distribution of the 21 known Texarkana phase burials at the Mitchell site is shown in Figure 52.

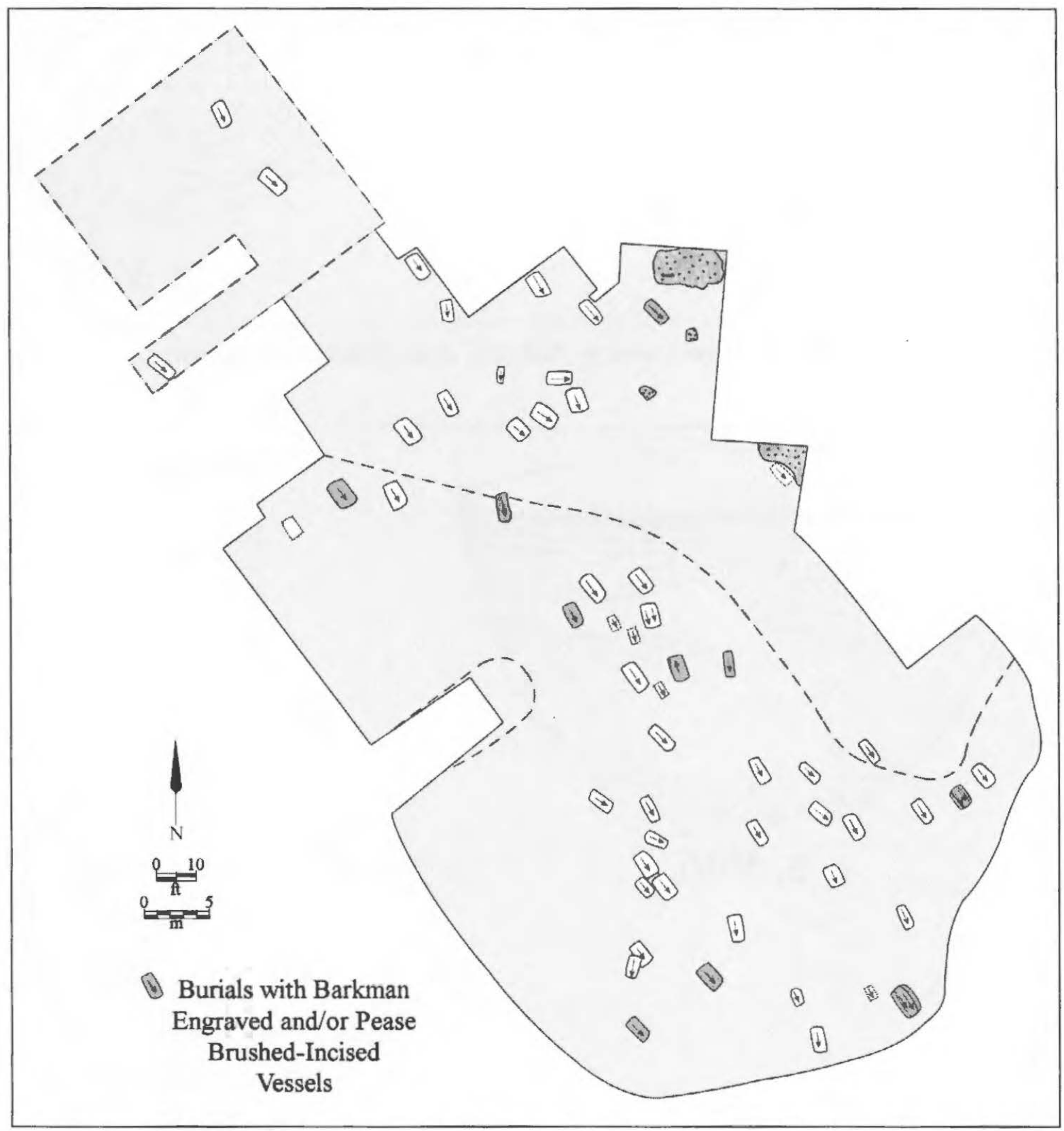

Figure 44. Distribution of burials with Barkman Engraved and Pease Brushed-Incised vessels. 

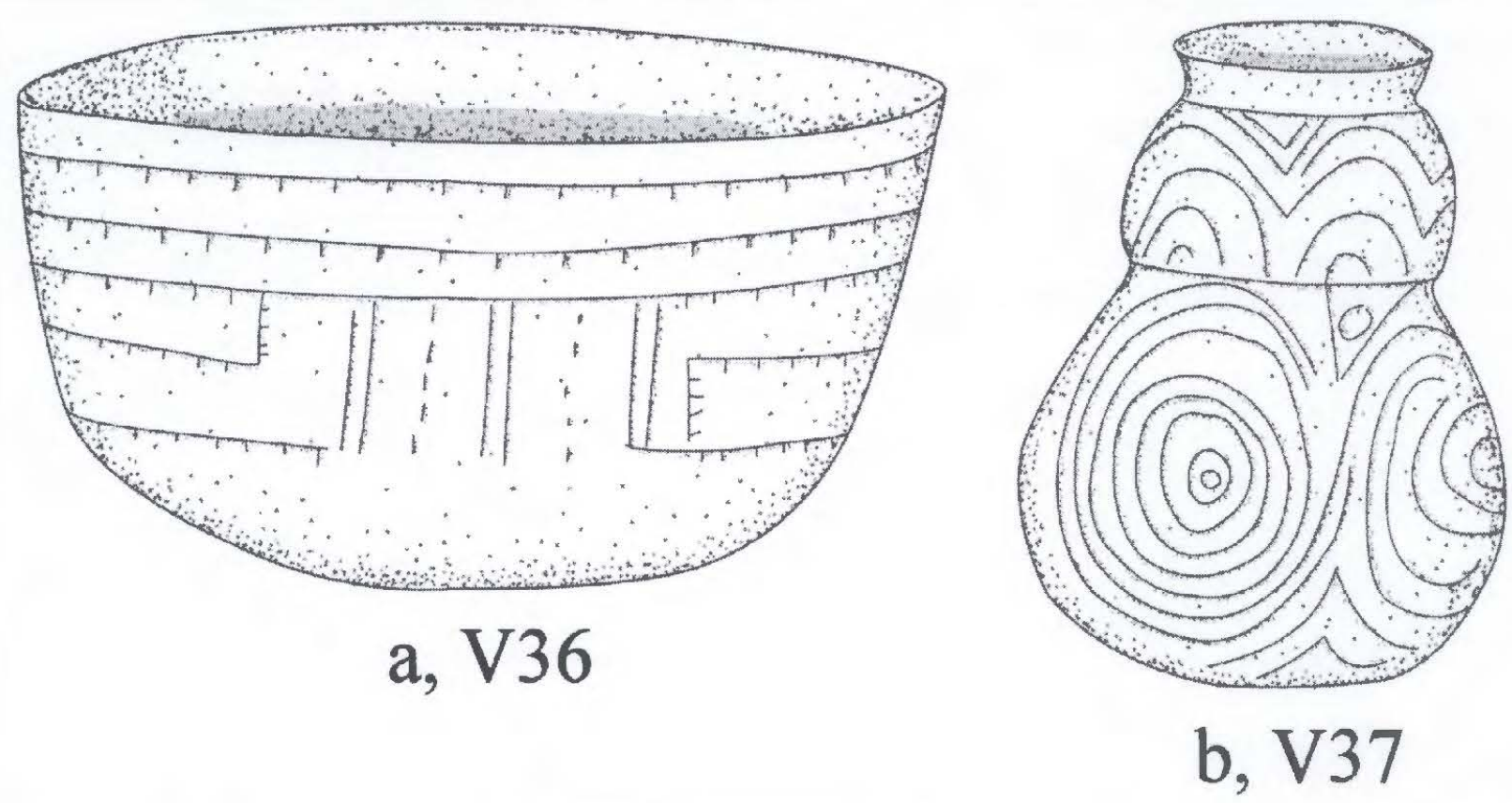

Figure 45. Vessels from Burial 11 excavated by Mathews at the Mitchell site cemetery.

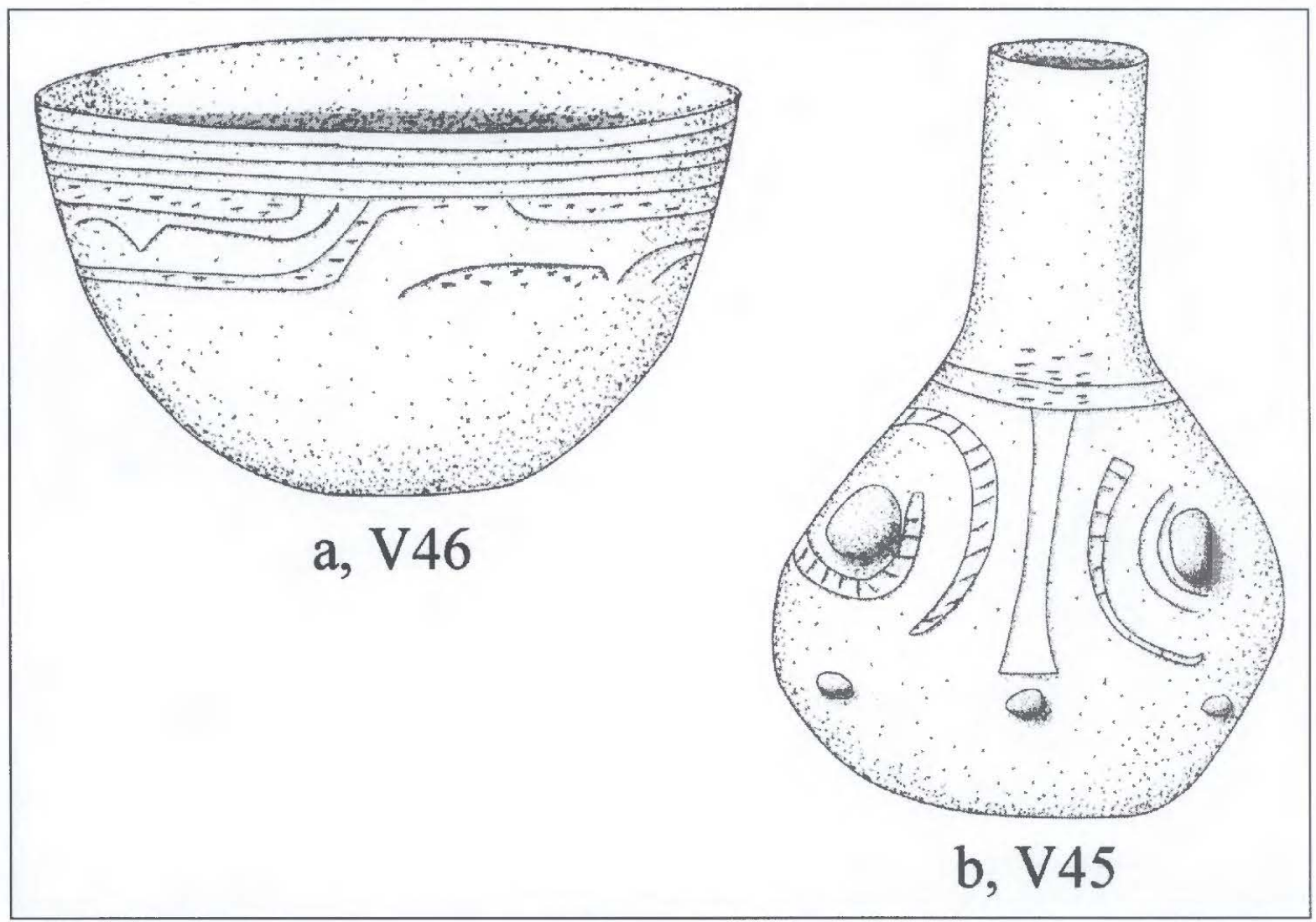

Figure 46. Vessels from Burial 14 excavated by Mathews at the Mitchell site cemetery. 


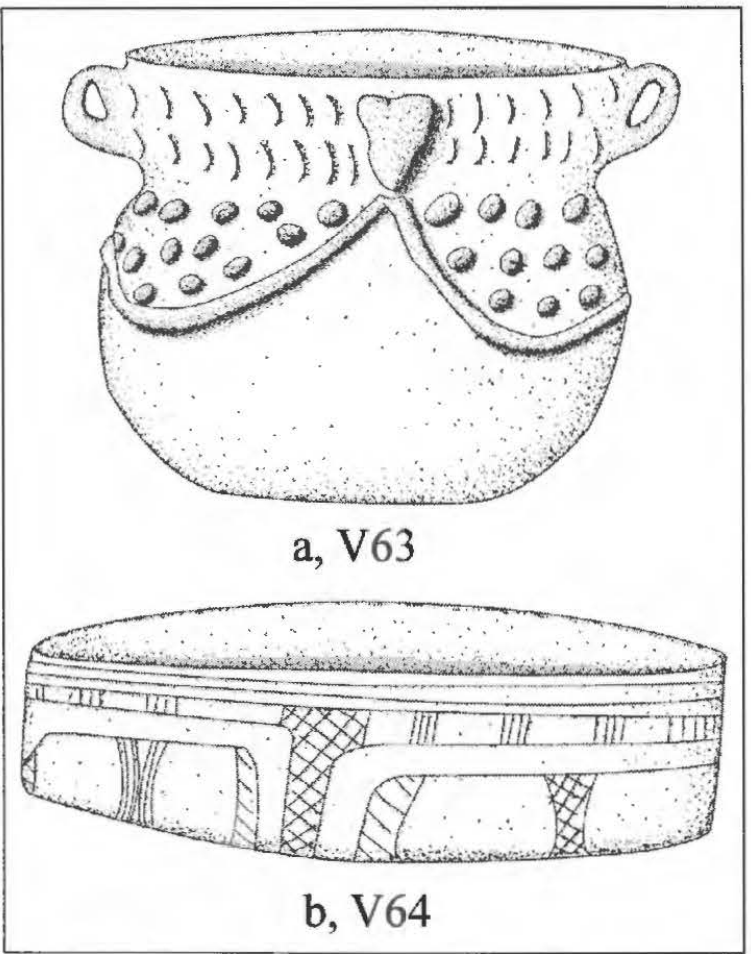

Figure 47. Vessels from Burial 15 excavated by Mathews at the Mitchell site.

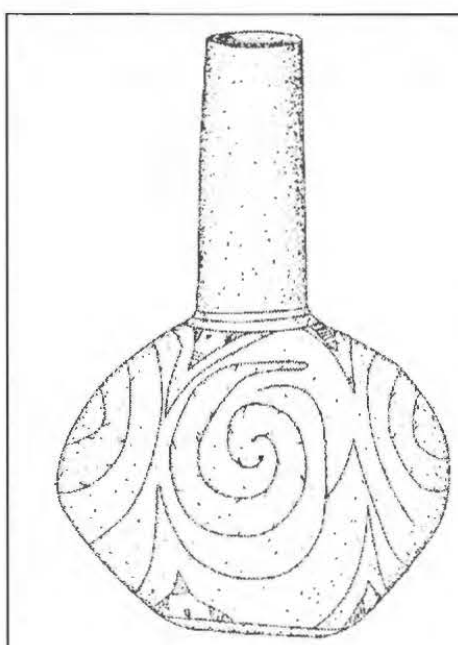

a, V51

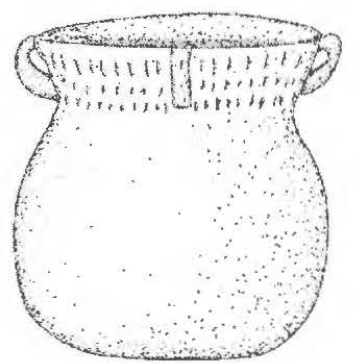

b, V50

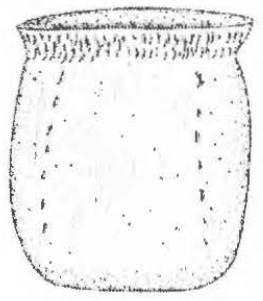

c, V49

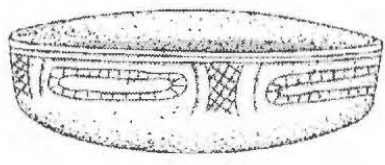

Figure 48. Vessels from Burial 20 excavated by Mathews at the Mitchell site.

d, V47

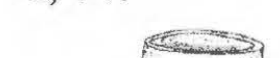

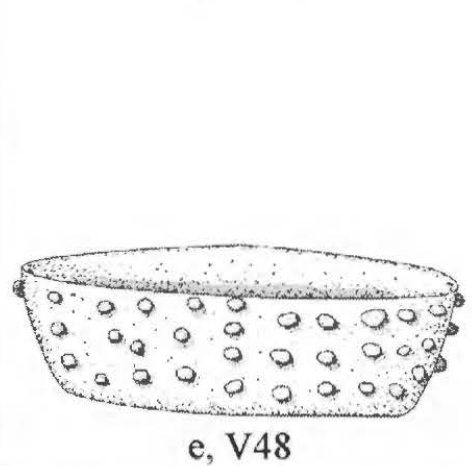

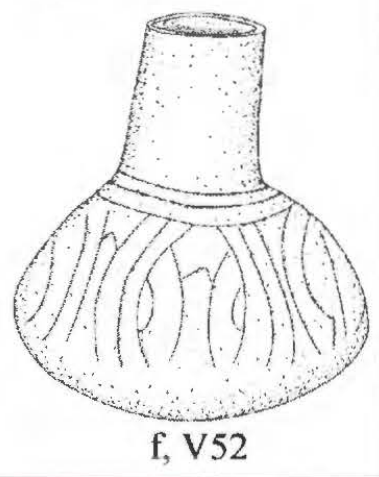




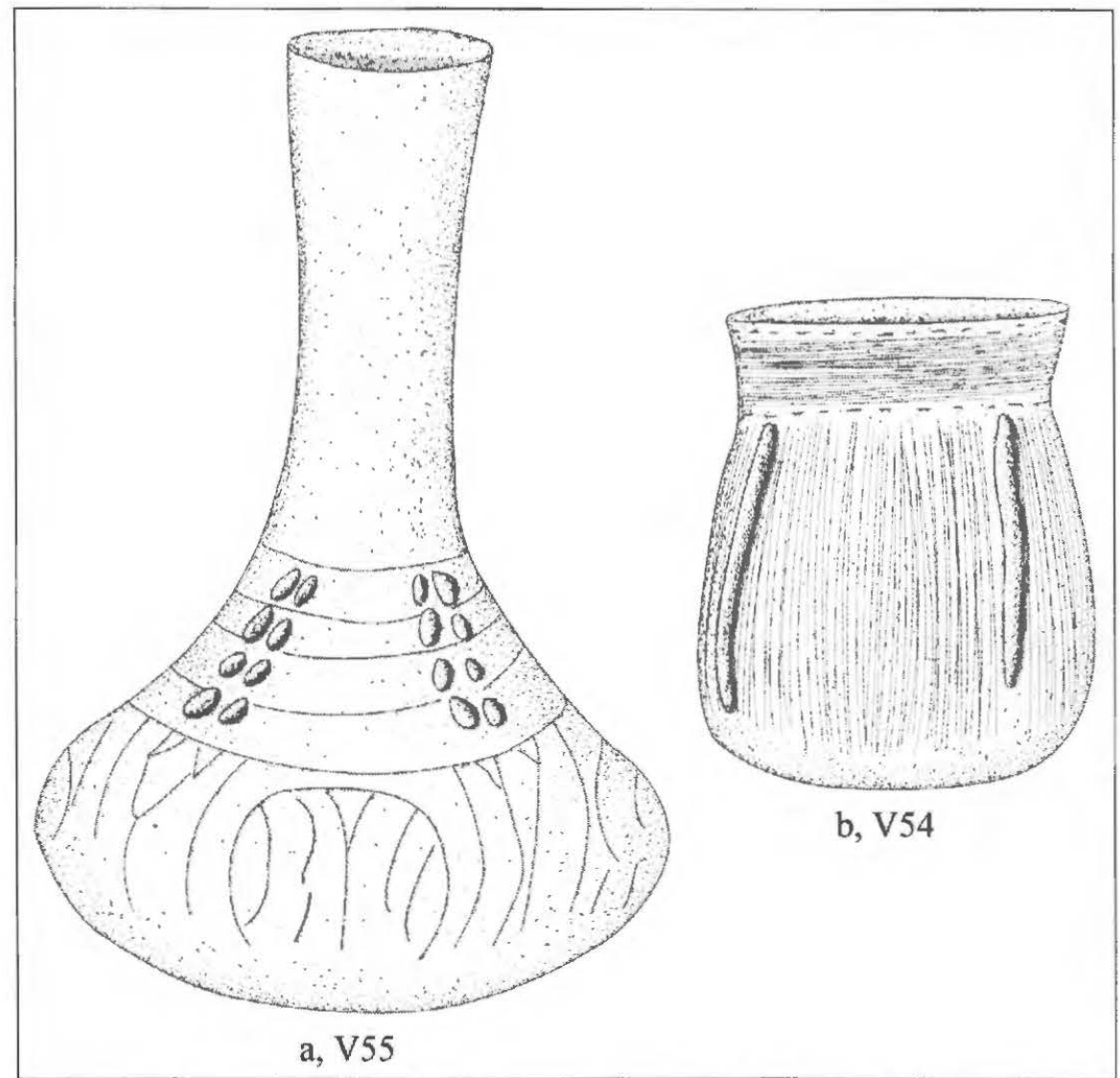

Figure 49. Vessels from Burial 17 excavated at the Mitchell site cemetery by Mathews.

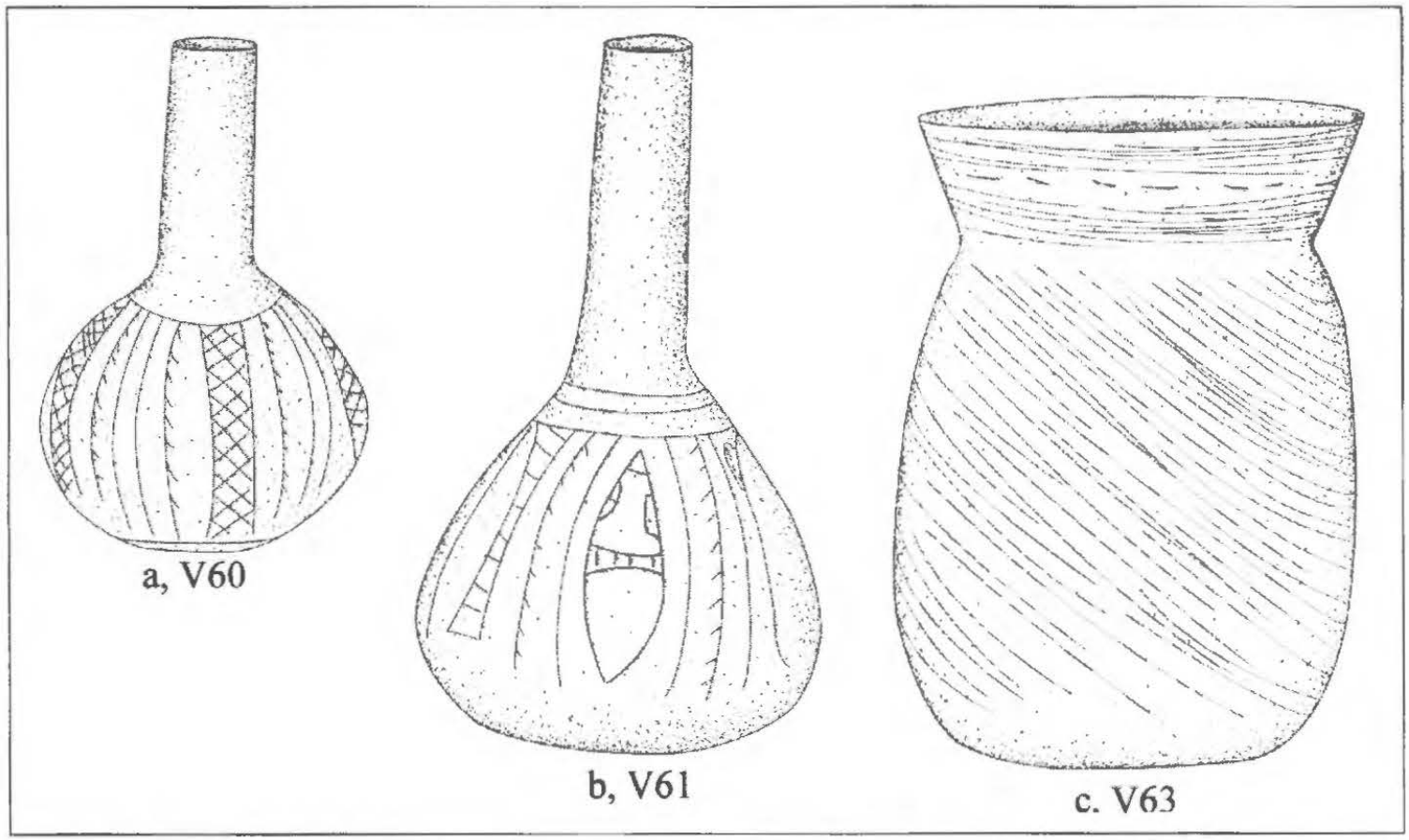

Figure 50. Vessels from Burial 19 excavated by Mathews at the Mitchell site. 


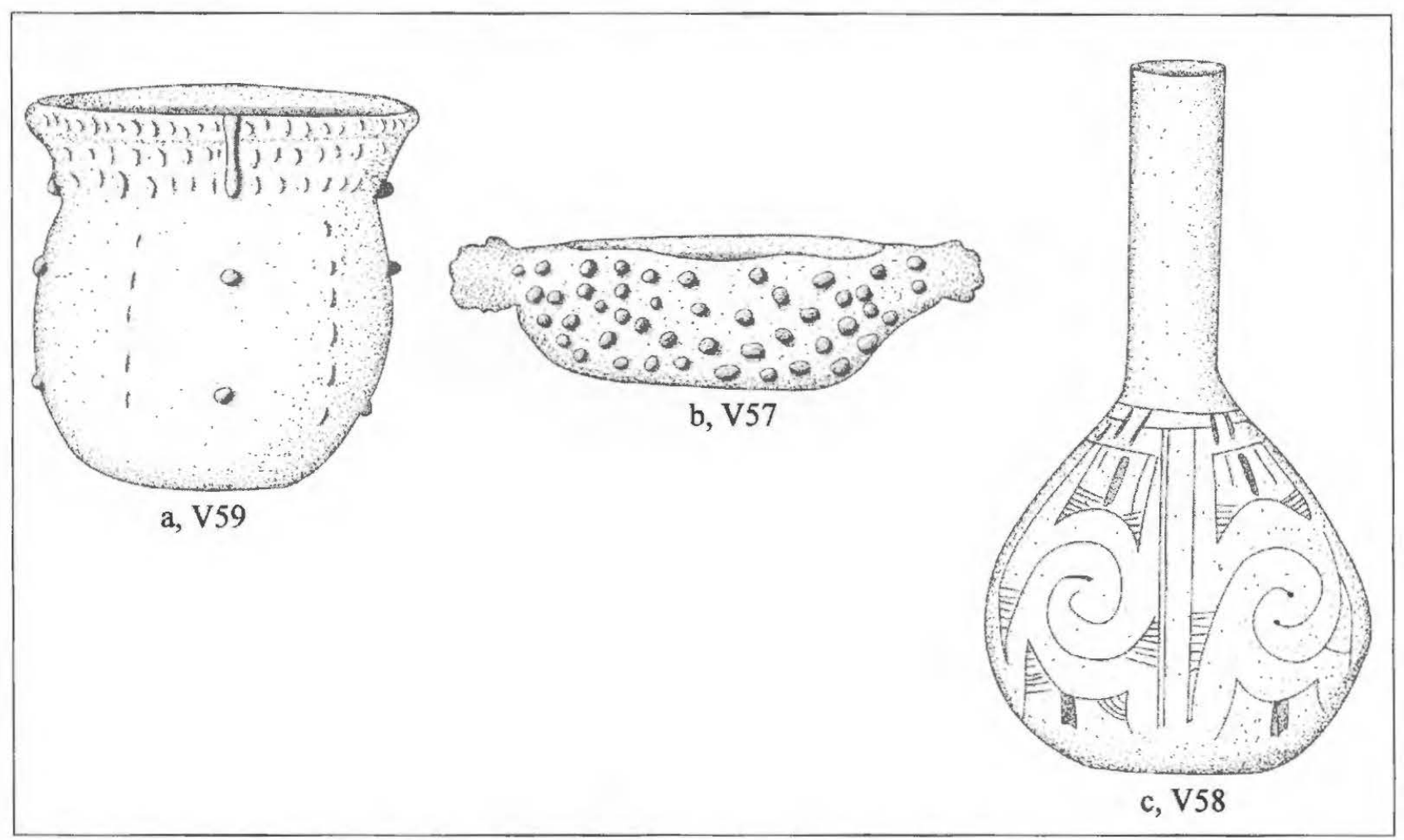

Figure 51. Vessels from Burial 18 excavated by Mathews at the Mitchell site.

\section{Post-A.D. 1550}

The very latest Texarkana phase set of vessels (i.e., postdating ca. A.D. 1550-1600) in sites in the Upper Nasoni Caddo village include vessels of the following defined ceramic types: Simms Engraved (Figure 53b), Hodges Engraved, Belcher Engraved, Keno Trailed, Taylor Engraved (see Figures 45b and 47a, and possibly 51c), Foster Trailed-Incised, Nash Neck Banded, and McKinney Plain vessels. Such vessels have been found in burial features in the upper mound stages at the Hatchel temple mound (Perttula 2014a), the late burial interments in Village Plot 2 at the Hatchel site, and several of the burials at the Eli Moores site (cf. Creel 1991; Perttula 1992:125-126, 2014b). There are also a few such very late Texarkana phase burials in the cemetery at the Mitchell site, for example Burial 12 in the Mathews excavations (Figure 53a-c) with a Simms Engraved carinated bowl, an engraved bottle, and a scalloped rim engraved carinated bowl; Burial 31 in the WPA excavations, with a Belcher Engraved carinated bowl as well as an Avery Engraved vessel, a plain bottle, and a McKinney Plain jar with vertical appliqued elements; and Burial 41 in the WPA excavations, with a Simms Engraved carinated bowl and an appliqued-punctated jar.

\section{Ceramic Pipes}

Midden excavations recovered a Red River style (see Hoffman 1967) pipe stem fragment at the Mitchell site. The stem has an exterior diameter of $9.0 \mathrm{~mm}$, and a hole diameter of $3.1 \mathrm{~mm}$, suggesting the stem is from either the Graves Chapel or Haley varieties. There are also the pointed butt end of two Haley variety long-stemmed pipes; one is tempered with bone and the other is tempered with grog. The exterior diameter of the pipe butt end sherds range from 11.0-13.8 mm. These pipes are from ca. A.D. 1200-1400 contexts at the site. 


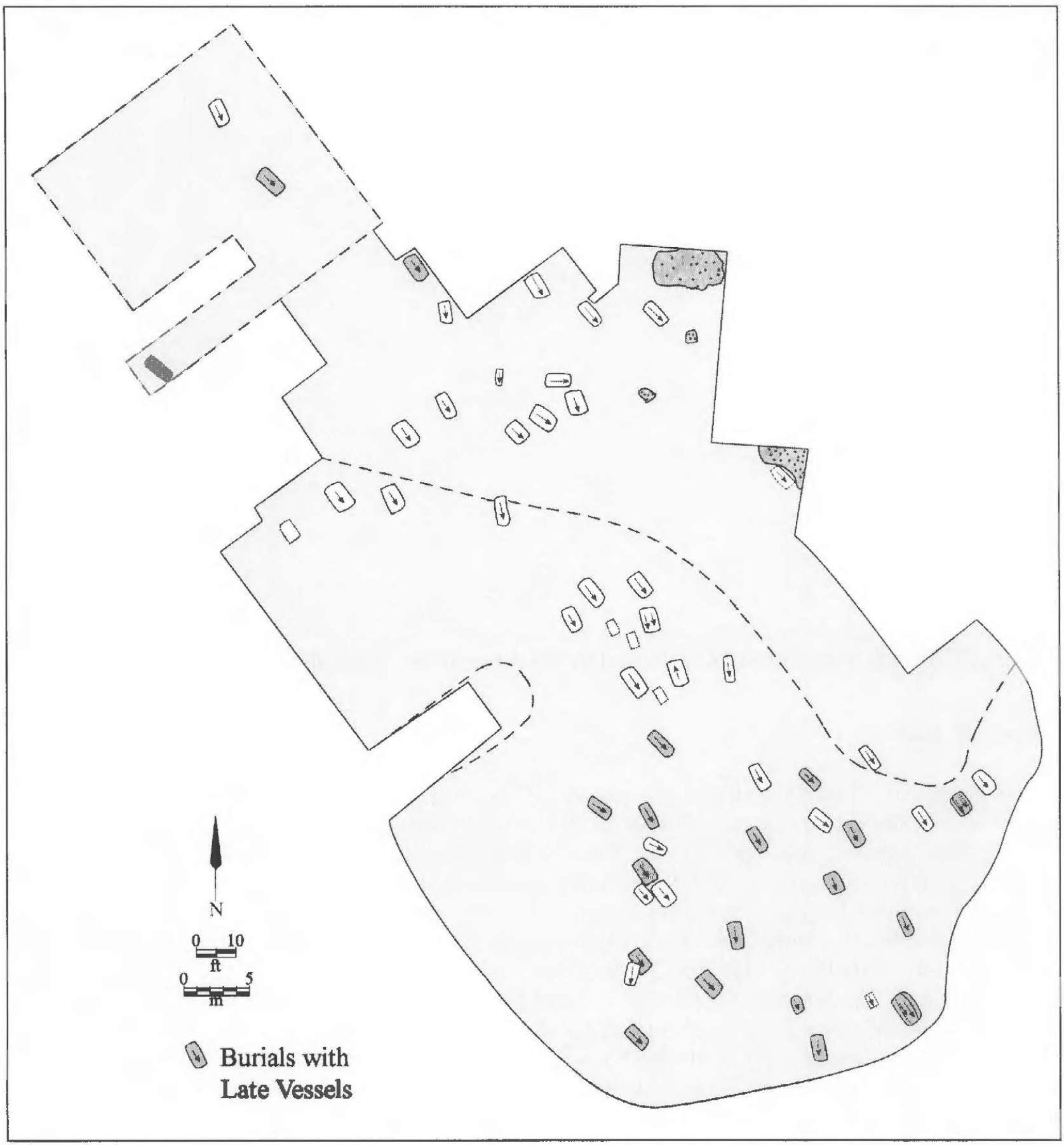

Figure 52. Distribution of Texarkana phase burials in the Mitchell site cemetery.

There are also elbow pipes in the Mitchell site burial assemblage, and these are from Texarkana phase burial features. The first is a bone-tempered pipe bowl fragment (6-2-140 from Burial 49B), with a height of $33.1 \mathrm{~mm}$ and an orifice diameter of $33.5 \mathrm{~mm}$. The second elbow pipe is a complete pipe tempered with grog, and has a rounded stem with a blunt end behind the pipe bowl (Figure 54). The height of the pipe is $43.0 \mathrm{~mm}$, with a bowl height of $21.2 \mathrm{~mm}$. The pipe bowl orifice diameter is $34.5 \mathrm{~mm}$. The exterior stem diameter is $28.3 \mathrm{~mm}$, and the stem bole is $13.0 \mathrm{~mm}$. 


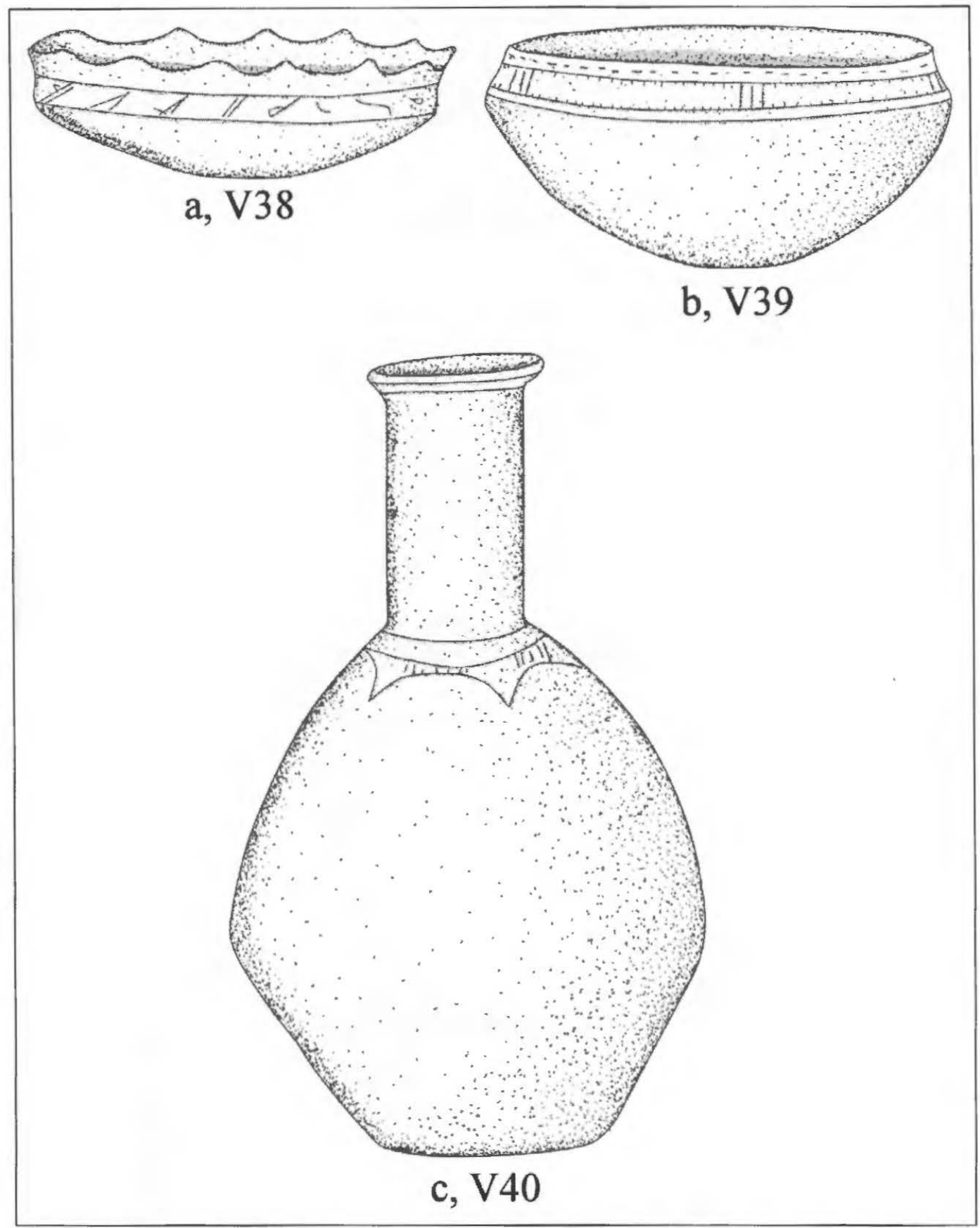

Figure 53. Vessels from Burial 12 excavated by Mathews in the Mitchell site cemetery.

Elbow pipes are also funerary offerings in Burials 3, 19, and 28 (Figure 55a-c). These are tempered with either grog $(n=2)$ or bone. Two of the elbow pipes are plain, but have small angular knobs near the juncture of the bowl and stem. The third elbow pipe has a triangular raised area on the back side of the pipe howl that is decorated with horizontal incised lines and two rows of small punctations (Figure 55c). Pipe heights on these elbow pipes range from 23.1-31.2 mm, and they are between $34.9-45.1 \mathrm{~mm}$ in total length; bowl heights are 12.9-19.0 mm. Bowl orifice diameters are 26.0-36.0 mm; outer stem diameters are 18.1-23.0 $\mathrm{mm}$; and stem hole diameters range from 9.0-12.0 $\mathrm{mm}$. 
Other burial pipes include two long-stemmed Red River pipes, probably var. Haley (see Hoffman 1967), from Burials 66 and Burial 69 (Figure 56a-b) in the Middle Caddo portion of the cemetery (see Figure 31). Both of these pipes are bone-tempered, with pipe heights that range from 31.0-37.0 mm. Pipe bowl orifice diameters are 34.9-41.1 mm, and outer stem diameters range from 12.0-13.0 mm. Stem holes are $6.0-6.4 \mathrm{~mm}$ in diameter.

\section{Ceramic Sherds}

The analysis of the ceramic sherds from habitation contexts at the Mitchell site focuses on the decorated sherds from utility (i.e., wet paste decorations) and fine (i.e., hard paste decorations) ware vessels. The decorated sherd assemblage is almost exclusively grog-tempered, as are the sherds from Village Plot 1 at the nearby Hatchel site (Perttula 2014a), with only between 2.4-3.0 percent of the sherds at the Mitchell site having come from vessels tempered with bone (Table 3). At the Hatchel site, Village Plot 1, 11.4 percent of the sherds are from vessels with bone temper. There are no shell-tempered sherds in the assemblage of decorated sherds from Mitchell site habitation contexts; however, one plain body sherd in the fill of Burial 51 is from a shell-tempered vessel (see below).

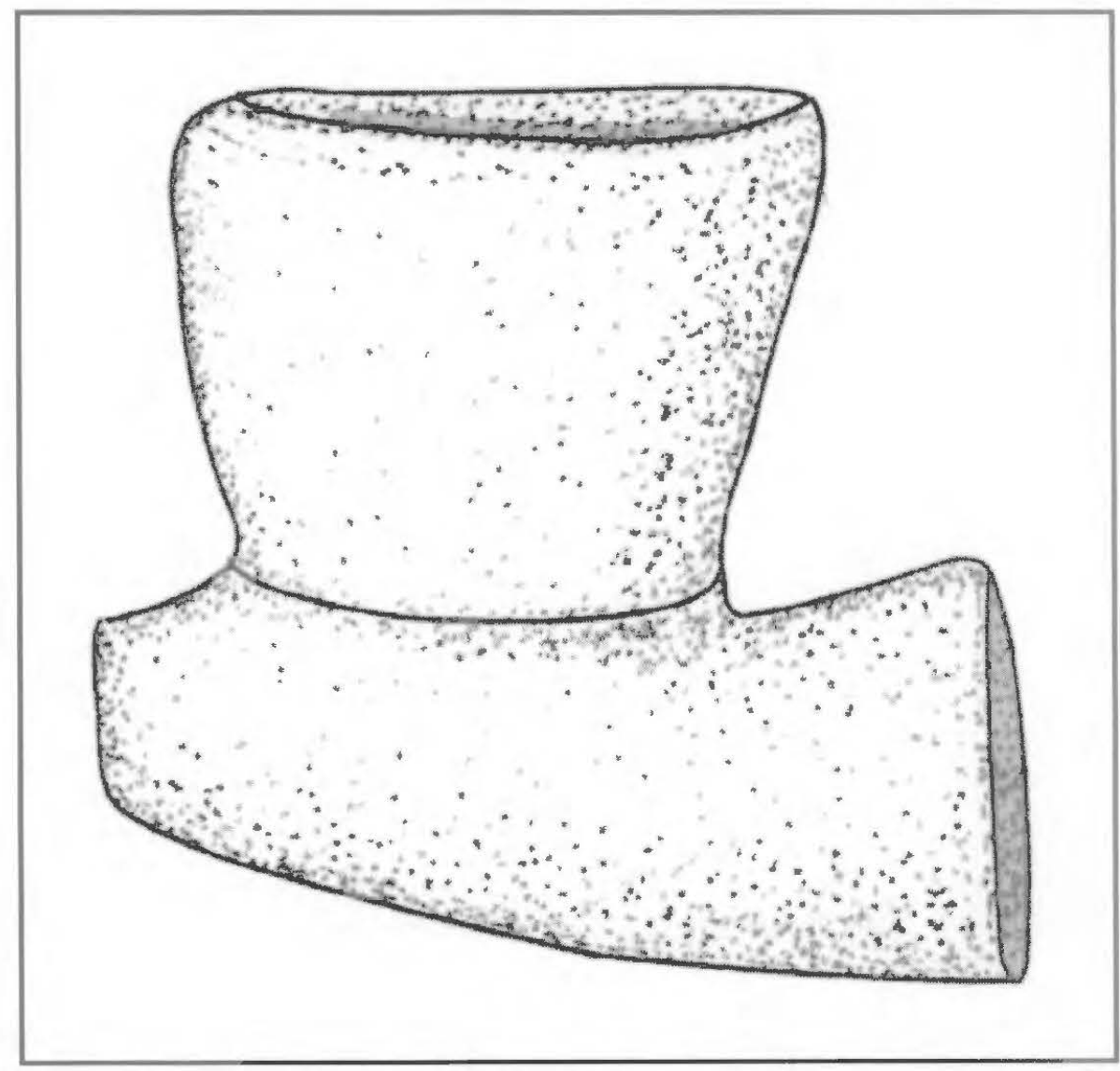

Figure 54. Elbow pipe from the Mitchell site (6-2-127). 


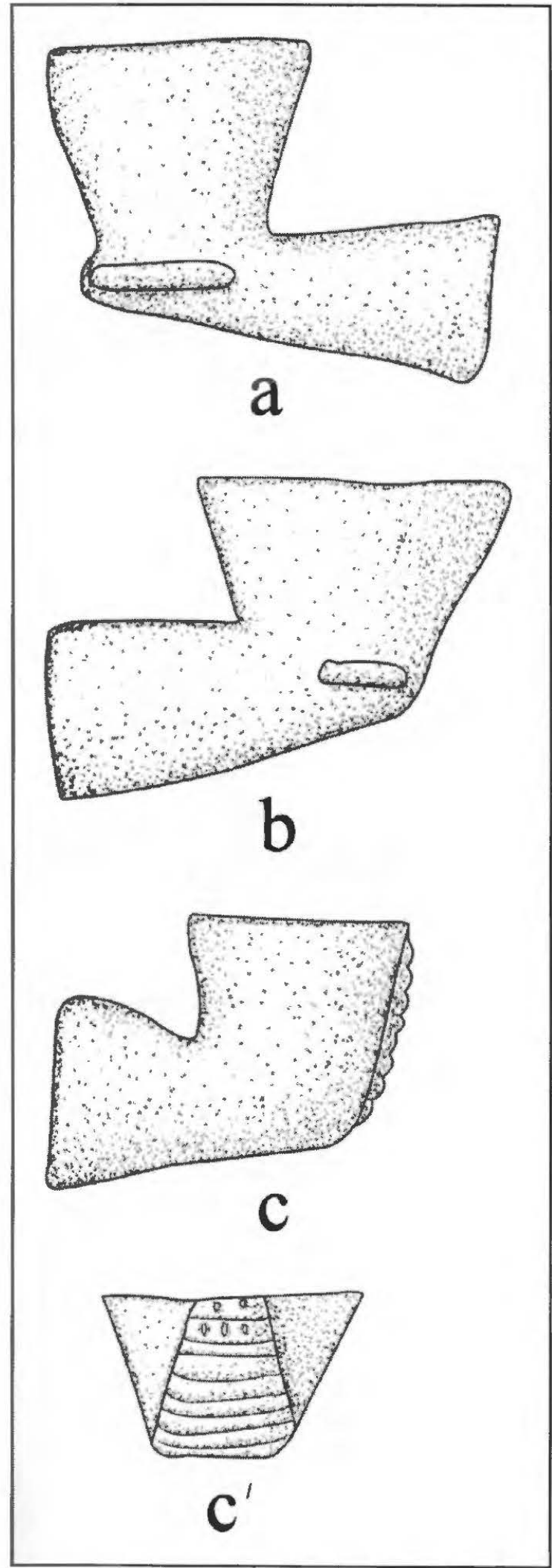

Figure 55. Elbow pipes from Mitchell site burials: a, Burial 3; b, Burial 19; c, Burial 28. 


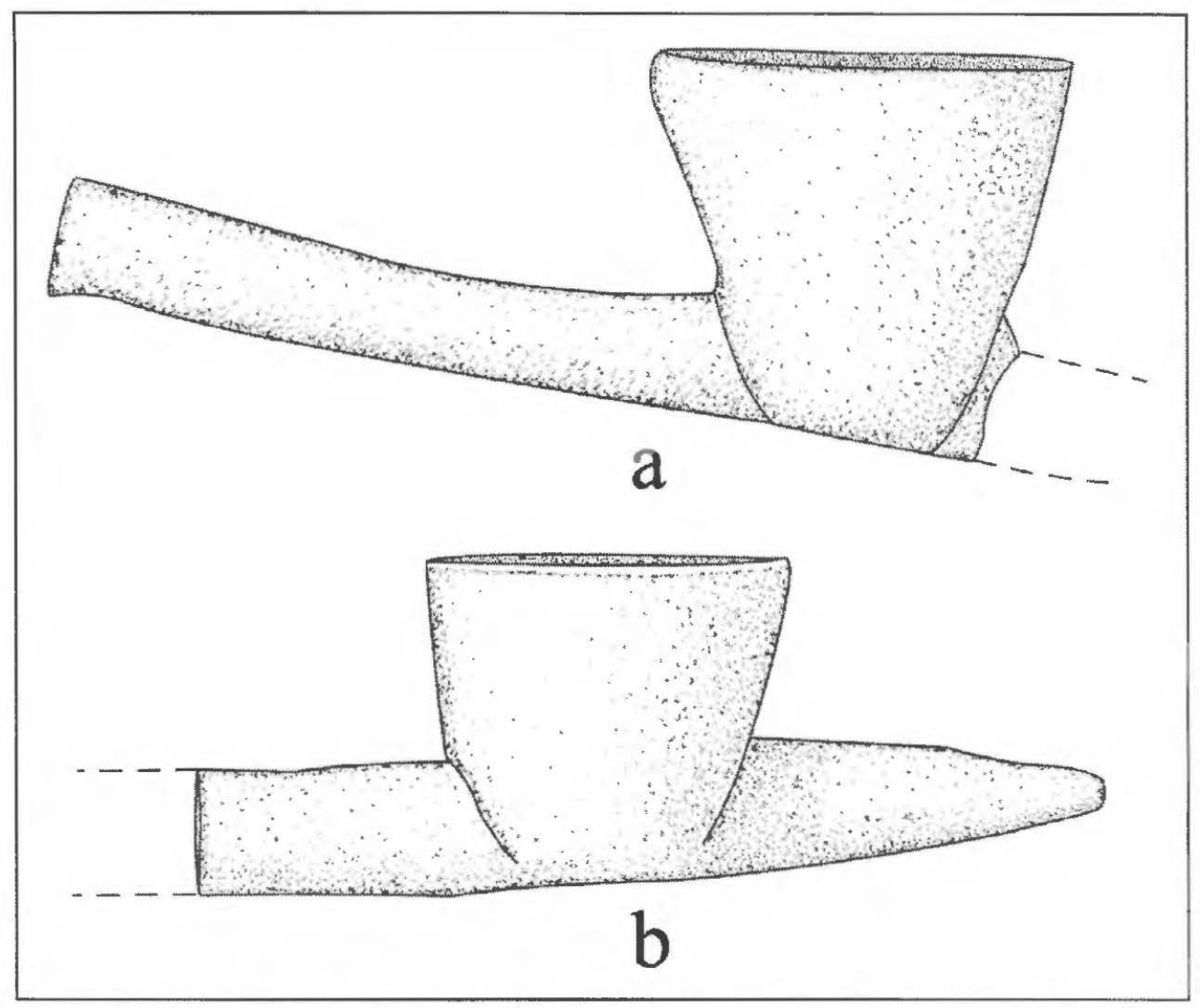

Figure 56. Long-stemmed Red River pipes from the Mitchell site: a, Burial 66; b, Burial 69).

Table 3. Use of temper in ceramic sherds from non-burial contexts at the Mitchell site.

\begin{tabular}{lrrrr}
\hline Ware & $\%$ Grog & $\%$ Bone & $\%$ Shell & N \\
\hline Utility ware & 97.0 & 3.0 & - & 134 \\
Fine ware & 97.6 & 2.4 & - & 82 \\
\hline Totals & 97.2 & 2.8 & - & 216 \\
\hline
\end{tabular}

\section{Utility Wares}

Sherds from vessels with wet paste decorations in the Mitchell site ceramic assemblage are from utility wares, primarily from jars. These sherds comprise 62 percent of the decorated sherd assemblage from non-mortuary contexts at the site (Table 4). Fine ware sherds-from vessels with engraved, red-slipped, and trailed decorations - account for 38 percent of the decorated sherd assemblage. 
Table 4. Utility ware and fine ware sherds in the Mitchell site non-burial ceramic assemblage.

\begin{tabular}{|c|c|c|c|c|}
\hline Decorative method & $\operatorname{Rim}$ & Body & $\mathrm{N}$ & $\%$ \\
\hline \multicolumn{5}{|l|}{ Utility ware } \\
\hline Appliqued & 1 & 5 & 6 & 2.8 \\
\hline Appliqued-Incised & - & 1 & 1 & 0.5 \\
\hline Appliqued-Pinched & - & 1 & 1 & 0.5 \\
\hline Appliqued-Punctated & - & 2 & 2 & 0.9 \\
\hline Brushed & - & 8 & 8 & 3.7 \\
\hline Brushed-Appliqued & - & 2 & 2 & 0.9 \\
\hline Brushed-Incised & 1 & 2 & 3 & 1.4 \\
\hline Brushed-Punctated & 1 & 3 & 4 & 1.8 \\
\hline Incised & 12 & 36 & 48 & 22.2 \\
\hline Incised-Pinched & - & I & 1 & 0.5 \\
\hline Incised-Punctated & 6 & 22 & 28 & 13.0 \\
\hline Pinched & - & 2 & 2 & 0.9 \\
\hline Punctatcd, fingernail & 1 & 10 & 11 & 5.1 \\
\hline Punctated, tool & 3 & 8 & 11 & 5.1 \\
\hline Punctated, fingernail-tool & - & 1 & 1 & 0.5 \\
\hline Trailed & 2 & 2 & 4 & 1.8 \\
\hline Trailed-Punctaled & - & 1 & 1 & 0.5 \\
\hline Subtotal & 27 & 107 & 134 & 62.0 \\
\hline \multicolumn{5}{|l|}{ Fine ware } \\
\hline Engraved* & 17 & 45 & 62 & 28.7 \\
\hline Red-slipped & - & 9 & 9 & 4.2 \\
\hline Trailed & - & 11 & 11 & 5.1 \\
\hline Subtotal & 17 & 65 & 82 & 38.0 \\
\hline Totals & 44 & 172 & 216 & 100.0 \\
\hline
\end{tabular}

*includes sherds with engraved and excised punctated elements

Most of the utility ware sherds from the Mitchell site have incised (36 percent of the utility wares and 44 percent of the utility ware rims), incised-punctated ( 21 percent of the utility wares and 22 percent of the utility ware rims), and punctated ( 17 percent of the utility wares) decorative elements, but therc is a wide assortment of other wet paste decorative elements; sherds with brushed elements (as the only decoration, or in combination with appliqued, incised, or punctated elements) comprise ca. 13 percent of the utility wares (see Table 4). The high proportion of incised and incised-punctated sherds in the Mitchell site ceramic assemblage from habitation contexts is similar to the assemblage of decorated sherds 
recovered in Village Area II at the Hatchel site. where they are associated with 11th-13th century A.D. calibrated radiocarbon dates (Perttula and Nelson 2003:15, 57 and Tables 6 and 15). These dates (and associated ceramics) are the first substantial evidence that the Hatchel site was occupied prior to the Late Caddo period.

There are also 190 sherds recovered from the fill of 15 ancestral Caddo burials, as well as a bone pit with redeposited human remains (Table 5). This includes 141 plain rim, body, and base sherds; 29 utility ware body sherds; and 20 fine ware rim and body sherds. The proportion of utility ware sherds among all the decorated sherds from burial fill is 59 percent, not much different from the proportions of utility $w_{i}$ : decorated sherds ( 62 percent) from non-burial contexts (see Table 4$)$. It is likely that both decorated sherd collections are from the same utility ware and fine ware ceramic assemblage; that is, these sherds a primarily from a pre-existing ceramic assemblage/occupational deposit (i.e., midden) into which many postA.D. 1400 burials were eventually interred by Caddo peoples, rather than the sherds from broken vessels left as funerary offerings. Exceptions to this include Barkman Engraved (Burial 27), Glassell Engraved (Burial 51), Hatchel Engraved (Burial 13), and Simms Engraved (Burial 66) sherds from four different burial features.

Table 5. Sherds from burial fill at the Mitchell site.

Burial No. Sherd Descriptions

Burial Kl

4 plain body; 1 diagonal opposed incised body: 1 parallel brushed-incised body;

7 parallel appliqued ridge body (same vessel)

Burial 6B

2 plain body ( 1 bone-tempered); 1 straight appliqued ridge body; 1 parallel

Burial 12 appliqued ridge body; 1 parallel brushed-incised body

Burial 13

Burial 17

1 plain body (bone-tempered)

1 plain bottle neck; 1 Hatchel Engraved bottle body

Burial 27

1 cross-hatched incised body; 1 opposed eng
body; 1 tool punctated body; 5 plain body

Burial 33

1 Barkman Engraved body; diagonal engraved carinatcd bowl body; 1 horizontal engraved body

Burial 43

3 plain body

Burial 45

Burial 47

Burial 48

2 plain bowl rims; 1 plain bottle; 2 plain body

1 tool punctated body; 2 incised-punctated body

8 plain body; 3 horizontal engraved rim ( 1 bone-tempered)

2 horizontal engraved rims (same vessel); I diagonal brushed-tool punctated body; 1 parallel incised body; 3 tool punctated body; 3 fingernail punctated body (same vessel); 1 parallel engraved body; 1 horizontal-diagonal engraved body;

Burial 50 8 plain bottle body; 4 base; 20 plain body 2 plain body; 2 plain bottlc body; 1 fingernail punctated body; 1 straight en aved body; 1 horizontal engraved rim; 1 engraved bottle body; one incised-punctated lower rim

Burial 51 11 plain body ( 1 bone-tempered, 1 shell-tempered); 1 base; 2 tool punctated body; I parallel appliqued ridge body; 1 incised-punctated body; 1 straight engraved bottle body; 1 horizontal engraved body; $1 \mathrm{cf}$. Glassell Engraved lower rim

Burial 63 sherdlets from incised jar; 64 plain bottle

Burial 66

Bone Pit 1 incised-punctated body; 1 possible Simms Engraved rim 2 plain body ( 2 bone-tempered) 


\section{Appliqued}

One rim sherd (direct rim and a flat lip) has an appliqued node at the lip; this may be from a Moore Noded bowl. The body sherds with appliqued decorative elements include one sherd from Feature 2 with a rectilinear appliqued ridge; another with curvilinear appliqued ridges (Figure 57a); sherds with either a straight appliqued ridge $(n=1)$ or a straight appliqued fillet; and a sherd with a cluster of appliqued nodes.

\section{Appliqued-Incised}

A single body sherd has a straight appliqued fillet with parallel incised lines on only one side of the fillet.

\section{Appliqued-Pinched}

A single appliqued-pinched body sherd came from Feature 2 (Square 55-L-2). It is decorated with pinched rows on either side of a single appliqued node.

\section{Appliqued-Punctated}

One body sherd in the assemblage has a single straight appliqued ridge in an area of a utility ware vessel otherwise decorated with randomly placed tool punctates. The other has a straight appliqued ridge amidst an area with circular punctations.

\section{Brushed}

A few utility ware jars, probably from Karnack Brushed-Incised vessels, have a brushed decoration on their bodies. The brushing is oriented either diagonally $(n=1$, one of the few bone-tempered utility wares) or as parallel marks ( $n=7$, probably oriented vertically).

\section{Brushed-Appliqued}

These body sherds may be from Pease Brushed-Incised jars with panels created by vertical appliqued elements, and the panels then filled with brushing. One has parallel brushing marks on either side of a straight appliqued fillet, while the other has opposed brushing marks on one side of a straight appliqued ridge.

\section{Brushed-Incised}

The brushed-incised rim sherd in the assemblage has horizontal brushing marks with overlying horizontal incised lines on it (Square 5-R-2, levels 3-4). One brushed-incised body sherd from Feature 1 (Square 25-L-4) has parallel brushing marks that are overlain with opposed parallel incised lines, while another from Feature 4 (Square 40-L-2) has cross-hatched brushed marks and incised lines.

\section{Brushed-Punctated}

The one brushed-punctated rim sherd (everted profile, with a rounded lip) has horizontal brushing marks below a row of tool punctates under the vessel lip. A lower rim sherd of a jar from the midden deposits on the east side of the cemetery has horizontal brushing marks on the rim, as well as a row of diagonal tool punctates at the rim-body juncture. A body sherd has diagonal brushing marks with a single 


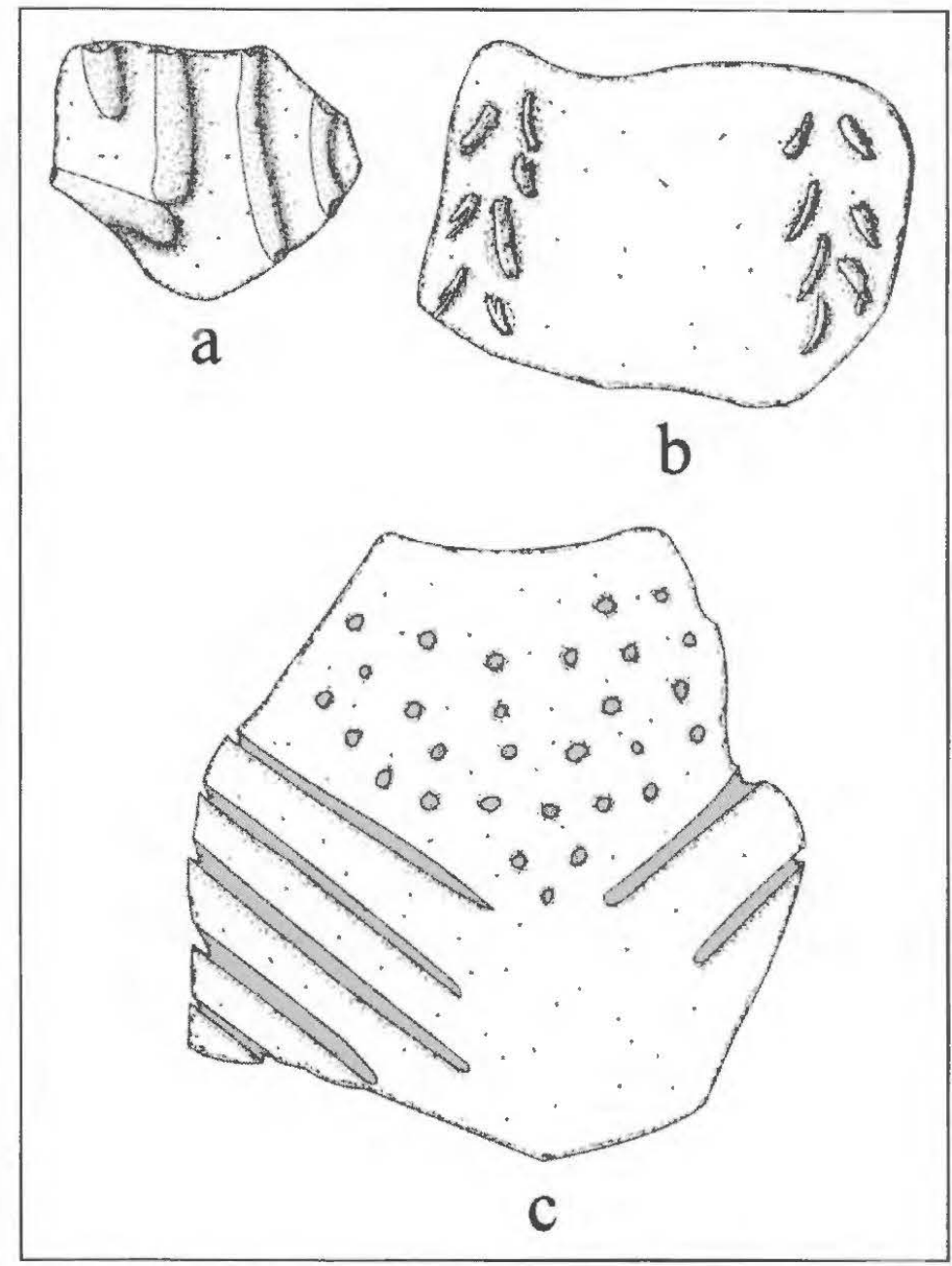

Figure 57. Appliqued, pinched, and trailed-punctated body sherds: a, appliqued; b, pinched; $c$, trailed-punctated (Foster Trailed-Incised). Provenience: a, General; b, Square 5-R-2, levels 3-4; c, Feature 1, Square 25-L-4.

row of tool punctates pushed through the brushing. A lower rim-body sherd from Feature 2 (Square 55-L1) has a row of tool punctates at the rim-body juncture and vertical brushing marks on the vessel body.

\section{Incised}

The majority of the vessels with incised decorations have horizontal lines on the rim, while the remainder have either diagonal opposed incised lines or combinations of horizontal or diagonal lines and other elements, such as cross-hatched triangles (Table 6 and Figure 58a-c). The diagonal opposed or chevron incised decorative element likely is associated with Dunkin Incised jars (cf. Suhm and Jelks 1962:Plate 19). Lower rim and body sherds have horizontal incised lines on the lower rim (Figure 58d-e) and in one instance (a sherd from a test pit in the midden east of the cemetery) a series of vertical incised lines on the vessel body (Figure 58f). 
Table 6. Decorative elements on incised sherds in the Mitchell site utility wares.

\begin{tabular}{lccc}
\hline Decorative element & Rim & Body & N \\
\hline Cross-hatched lines & - & 2 & 2 \\
Diagonal lines & 1 & - & 1 \\
Diagonal opposed lines (chevron) & 1 & 4 & 5 \\
Diagonal opposed and cross-hatched triangles & 1 & - & 1 \\
Horizontal line below the lip & 1 & - & 1 \\
Horizontal lines & 7 & 1 & 7 \\
Horizontal, curvilinear, and vertical lines & - & - & 1 \\
Horizontal and diagonal opposed lines & $1 *$ & 1 & 1 \\
Horizontal lines and hatched rectilinear zone & - & 1 & 1 \\
Horizontal-vertical lines & - & 1 & 1 \\
Opposed lines & - & 23 & 23 \\
Parallel lines & - & 2 & 2 \\
Straight line & - & 1 & 1 \\
Vertical lines & - & 36 & 48 \\
\hline Totals & 12 & & 1 \\
\hline
\end{tabular}

*rim has a small suspension hole below the lip

Other incised decorative elements are represented in the body sherds (see Table 6). This includes two body sherds with cross-hatched lines, one with opposed incised lines, and a body sherd with vertical incised lines.

\section{Incised-Pinched}

This one body sherd has parallel incised lines and a single pinched row.

\section{Incised-Punctated}

The sherds with incised-punctated decorative elements have a combination of incised lines oriented in various directions with either incised zones filled with punctations, or clse the punctations occur in one or more rows bclow the vessel lip or at the rim-body juncture. The inciscd zones tend to be curvilinear or triangular in shape, whether they occur on the rim or on the vessel body (Table 7 and Figure 59).

One of the larger incised-punctated sherds from a probable Dunkin Incised vessel section recovered in a Test Pit cast of the cemetery has distinctive decorative elements on both the rim and body (Figure 60 ). The rim has a diagonal opposed (chevron) incised element while the body is divided into panels by sets of $5+$ vertical incised lines. The panels are filled with rows of tool punctations.

The incised-punctated body sherds (including some lower rim and body sherd sections, as well as sherds from carinated bowls) also feature straight, curvilinear, and triangular incised zones filled with tool or fingernail punctations (Tablc 8 and Figure 6la-h, j); in one case, opposed incised lines form an open area lilled with punctations (Figure 61i), rather than a zone created by the incised lines themselves. These sherds have stylistic attributes similar to the decorative elements on both Crockett Curvilinear Incised and Pennington Punctated-Incised vessels (see Suhm and Jelks 1962:Plates 17 and 61). 


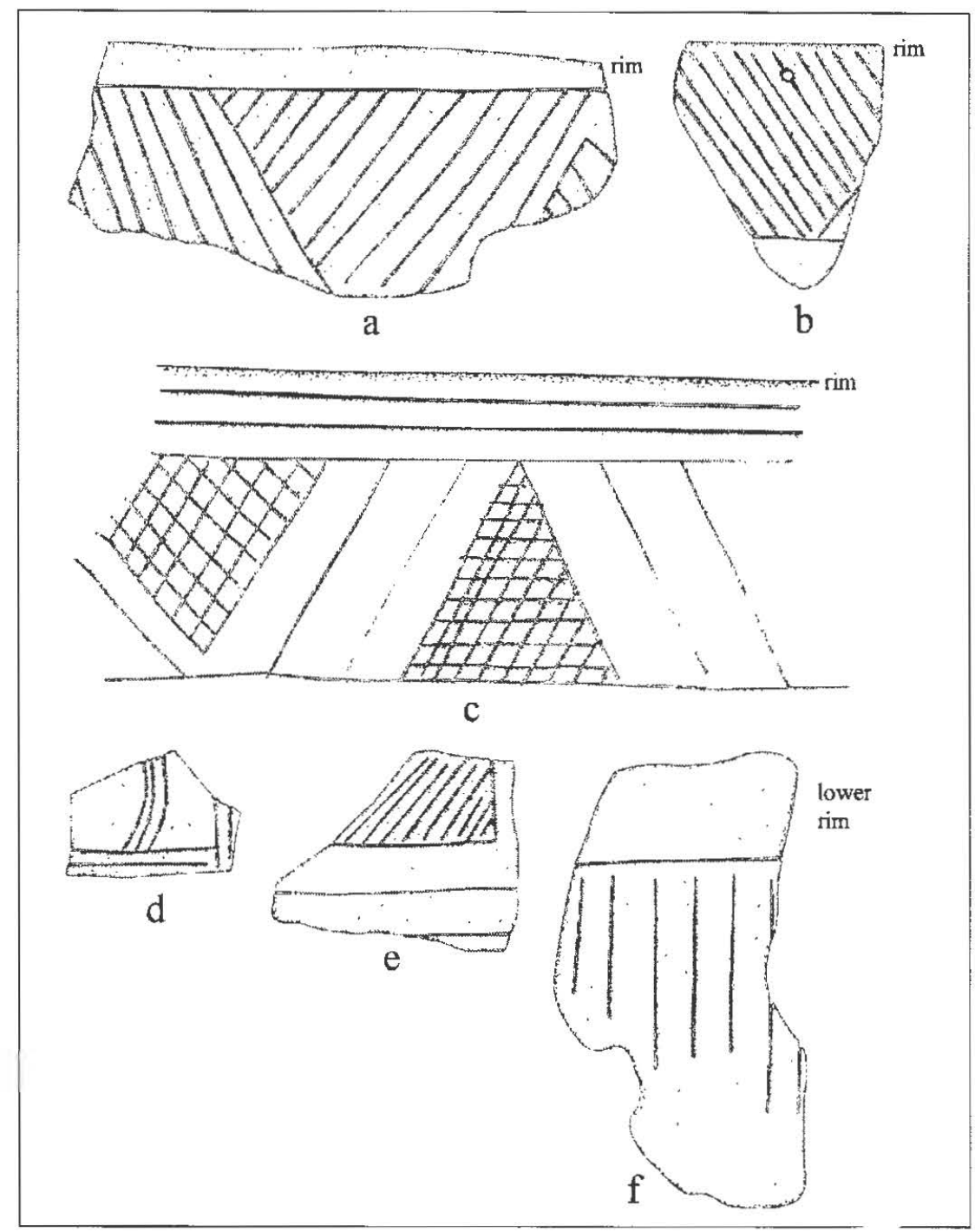

Figure 58. Incised rim and body sherds: a-c, rims; d-f, body and lower rim-body sherds. Provenience: a, Square 40-L-1, level 3; b; Square 30-L-3, layer 3; c, Square 5-L-3, layer 3; d, east side of cemetery, midden; e, east side of cemetery; $f$, Test Pit east of cemetery.

Table 7. Decorative elements on incised-punctated rim sherds.

Decorative element

Curvilinear incised zone filled with small tool punctates

Diagonal opposed incised lines and tool punctated-fillcd triangles

Diagonal opposed incised lines on rim; vertical incised lines on body, with

panels of tool punctated rows between the sets of vertical incised lines

Fingernail punctated rows above diagonal incised lines

Horizontal incised lines on rim; tool punctated row below lip

Sets of horizontal incised lines with diagonal incised zone between; tool punctated row below the lip 

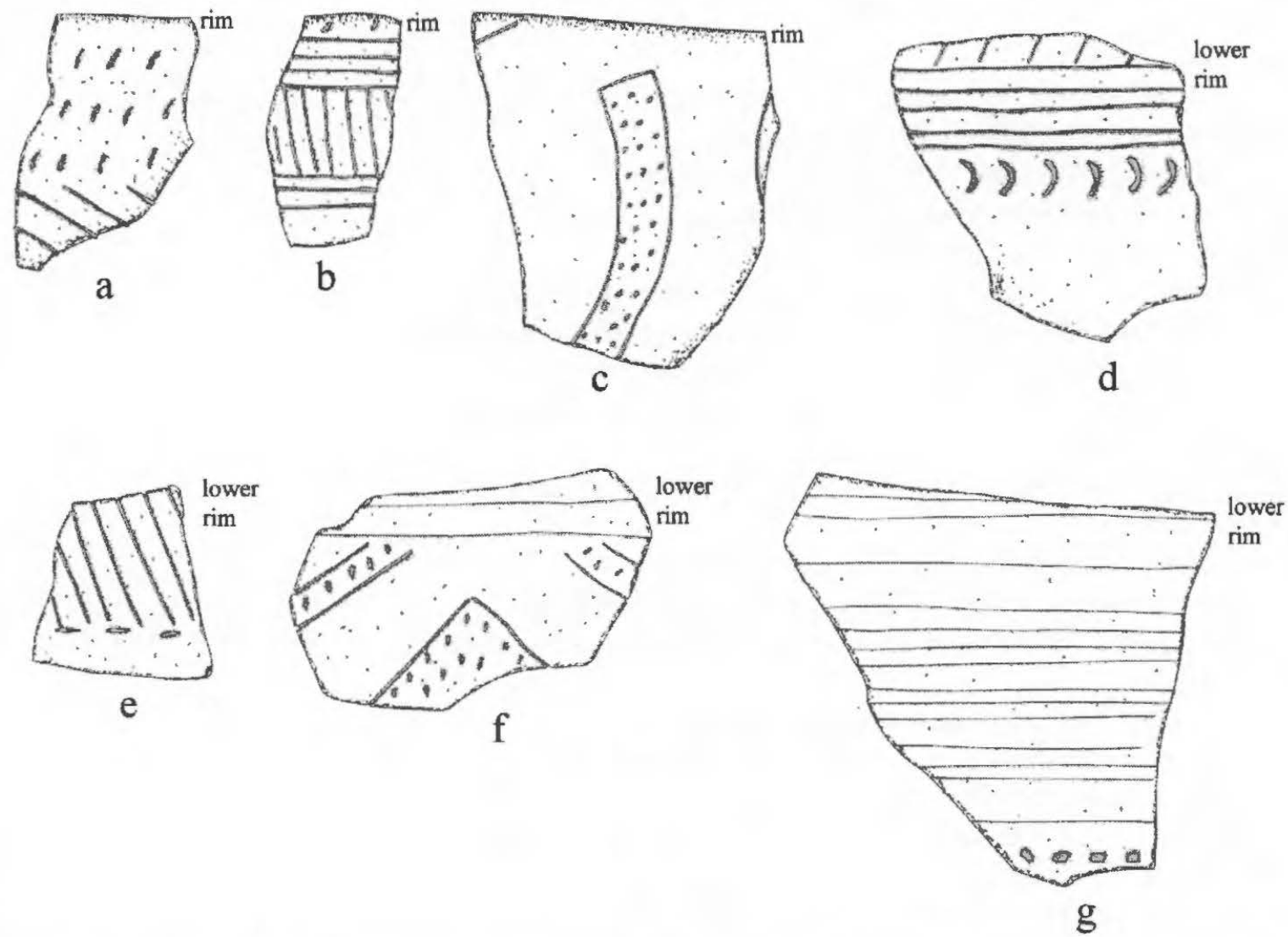

Figure 59. Incised-punctated rim and lower rim-body sherds in the Mitchell site utility wares. Provenience: a, pre-WPA surface collection; b-d east side of cemetery, midden; e, Burial 50 fill; f, east side of cemetery, midden; g, pre-WPA surface collection.

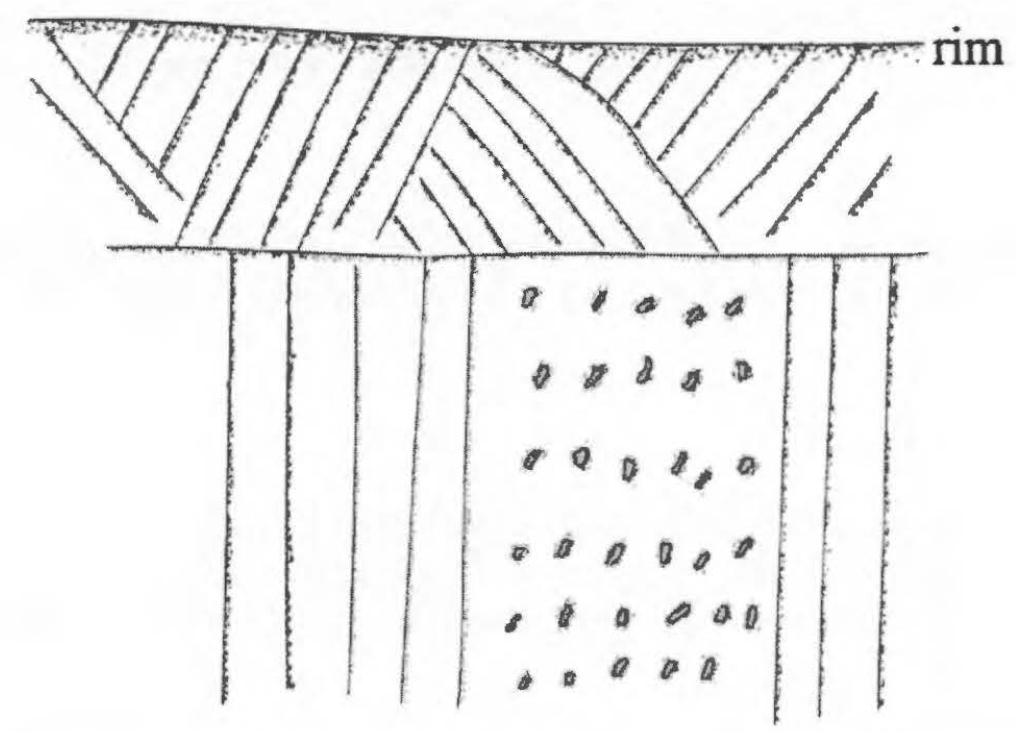

Figure 60. Decorative elements on an incised-punctated vessel rim and body section. Provenience: Test pit in midden, east of cemetery. 
Table 8. Decorative elements on incised-punctated body sherds.

Decorative elements

Circular incised zone filled with tool punctates

Cross-hatched incised lines and zones of tool punctates

Curvilinear incised zone filled with tool punctates

Diagonal incised lines above tool punctated row*

Diagonal incised lines and tool punctated-filled triangle element***

Diagonal opposed incised lines and tool punctated-filled triangle element

Horizontal incised lines, multiple, and tool punctated row*

Horizontal incised lines and diagonal and triangular incised zoncs filled*

with tool punctates

Horizontal and diagonal opposed lincs and crescent-shaped tool* punctated row

Opposed incised lines and tool punctated row

Parallel incised lines and panel filled with tool punctated rows

\section{1}

Parallel incised lines and panels filled with tool punctates and curvilinear hatched lines

Parallel incised lines and adjacent tool punctated row

Parallel incised lines and adjacent fingernail punctated row

Straight incised line and zone of crescent-shaped punctations**

Straight incised line and zones of tool and crescent-shaped punctations

Triangular incised zone filled with tool punctates

Triangular incised zones filled with fingernail punctates

Vertical incised lines and panels filled with tool punctates

*lower rim/body **carinated bowl

One carinated bowl sherd resembles a Weches Fingernail-Impressed vessel sherd because of its distinctive crescent-shaped fingernail punctations (see Figure 61a). However, the crescent-shaped punctations are not within narrow zones created by horizontal incised lines (cf. Suhm and Jelks 1962:Plate 77b, $\mathrm{d}-\mathrm{g})$, the most common decorative elements associated with this utility ware type.

\section{Pinched}

One of the body sherds with a pinched decoration has two vertical rows of pinching on the vessel body (see Figure 57b). The other, from Square 40-L-5, has horizontal pinched rows on the lower body of a jar.

\section{Punctated, fingernail}

The one fingernail punctated rim sherd is from midden deposits on the cast side of the cemetery. It has multiple horizontal rows of fingernail punctates. The fingernail punctated body sherds include sherds with rows of fingernail punctates ( $n=6$, two from 5-R-2, levels 3 and 4) or single fingernail punctates $(n=4)$. 


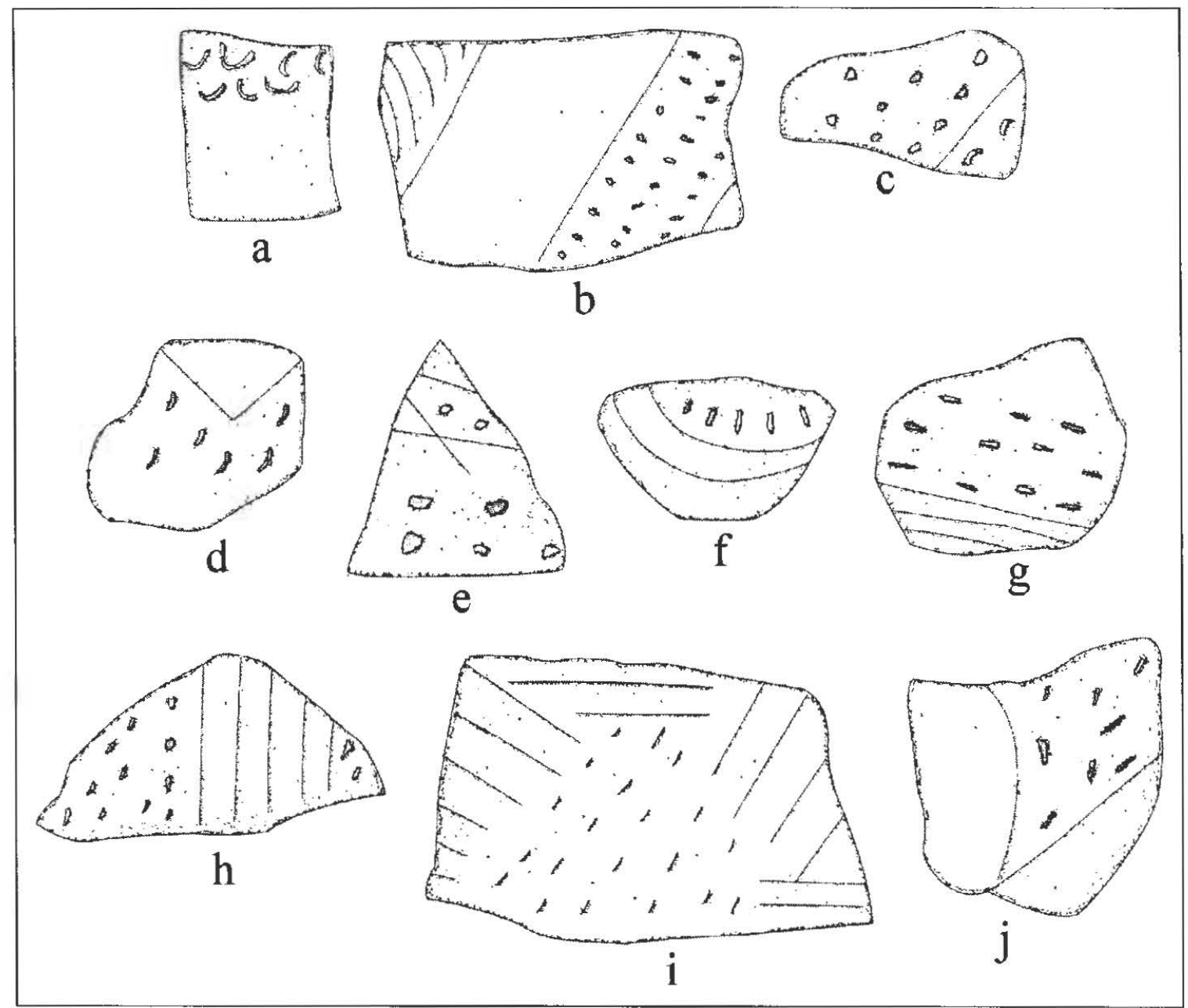

Figure 61. Incised-punctated body sherds. Provenience: a, pre-WPA surface collection; b, east side of cemetery, midden; c-e, east side of cemetery; $f$, Test Pit east of cemetery; $g$, Square 10-R-1; h, Burial 45 fill; i, east side of cemetery; j, Burial 66? fill.

\section{Punctated, tool}

Rims of utility vessels with tool punctated decorations include horizontal rows $(n=3)$; the rims have direct or everted profiles with rounded or flat lips. The tool punctated body sherds have the following elements: vertical tool punctated rows $(n=1)$; random tool punctates $(n=1,50-R-2$, layer 3$)$; and horizontal tool punctated rows ( $\mathrm{n}=6$, one from 10-R-5, level 3 ).

There is a section of a grog-tempered jar in the fill of Burial 35. The vessel was fired in a reducing cnvironment but cooled in the open air (see Teltser 1993:Figure 2f) and has $5.9 \mathrm{~mm}$ thick vessel walls. The jar is decorated by two horizontal rows of tool punctations at the rim-body juncture, and is probably of the Emory Punctated-Incised type or a similar Late Caddo utility ware. 


\section{Punctated, fingernail-tool}

One body sherd from Feature 2 (Square 55-L-3, layer 3) has parallel rows of lingernail punctates and a zonc filled with tool punctates.

\section{Trailed}

Foster Trailed-Incised sherds in non-burial contexts at the Mitchell site include two body sherds with parallel trailed lines, a rim (direct, with a rounded lip) with diagonal trailed lines, and a second rim with horizontal trailed lines. This rim is also direct in profile, with a rounded lip.

\section{Trailed-Punctated}

The one distinctive trailed-punctated sherd is from a Foster Trailed-lncised jar (see Figure 57c). The vessel lower rim has diagonal opposed trailed lines on either side of a zone of small circular punctates.

\section{Fine Wares}

The fine wares are represented by sherds from engraved ( 76 percent of the fine ware sherds), redslipped (11 percent of the fine ware sherds), and trailed ( 13 percent of the fine ware sherds) vessels. $\Lambda_{p^{-}}$ proximately 39 percent of the rim sherds from decorated vessels in the entire decorated sherd assemblage are from fine wares (see Table 4).

\section{Engraved}

Engraved rim sherds from non-burial contexts at the Mitchell site are dominated by horizontal decorative elements, with multiple rows of horizontal engraved lines on carinated bowls, or horizontal engraved lines in concert with narrow hatched zones and other elements (Table 9 and Figure $62 \mathrm{a}, \mathrm{d}, \mathrm{f}, \mathrm{h}$ ). A number of the engraved rim and body (lower rim) sherds from the site are readily identified as coming from Barkman Fngraved vessels (Figure 62a-g), and in total there are two rims and seven body sherds of this type in the fine wares, not including one body sherd from the fill of Burial 27

Table 9. Decorative elements on engraved rim sherds.

Decorative element

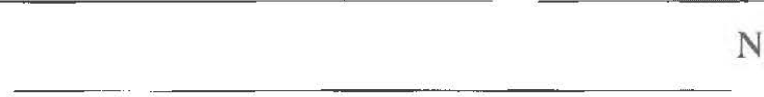

Horizontal engraved lines

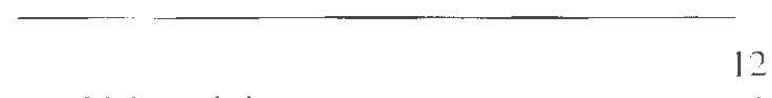

Horizontal engraved lines and excised punctated row on thickened rim

Horizontal engraved lines and narrow hatched zone

Horizontal engraved and large cross-hatched pendant triangles

Interlocking horizontal scrolls filled with small excised punctates

Vertical and curvilinear lines*

*also interior-exterior red-slipped

Another distinctive engraved fine ware in the Mitchell site assemblage is a rim sherd from a Handy Engraved carinated bowl (Suhm and Jelks 1962:Plate 32). This rim has an interlocking horizontal scroll motif with the scroll elements filled with small excised punctations (sec Figure 62h). Handy Engraved is 


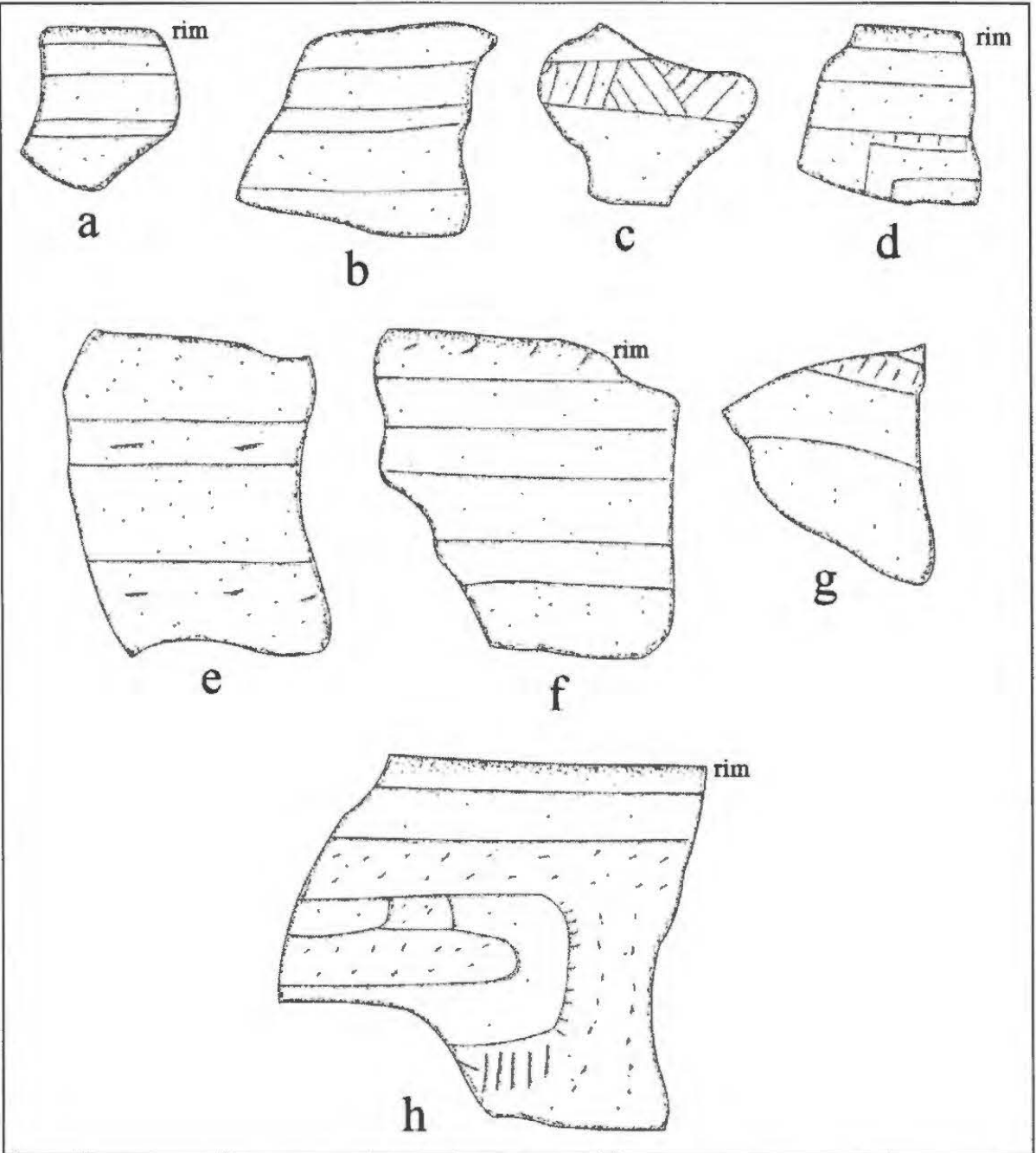

Figure 62. Barkman Engraved and Handy Engraved rim and body sherds. Provenience: a, Feature 2, 55-L-1; b-c, Feature 1, 25-L-4; d-e, Feature 2, 60-L-3; f, east side of cemetery, midden; g, pre-WPA surface collection; $h$, 50-L-2, layer 3.

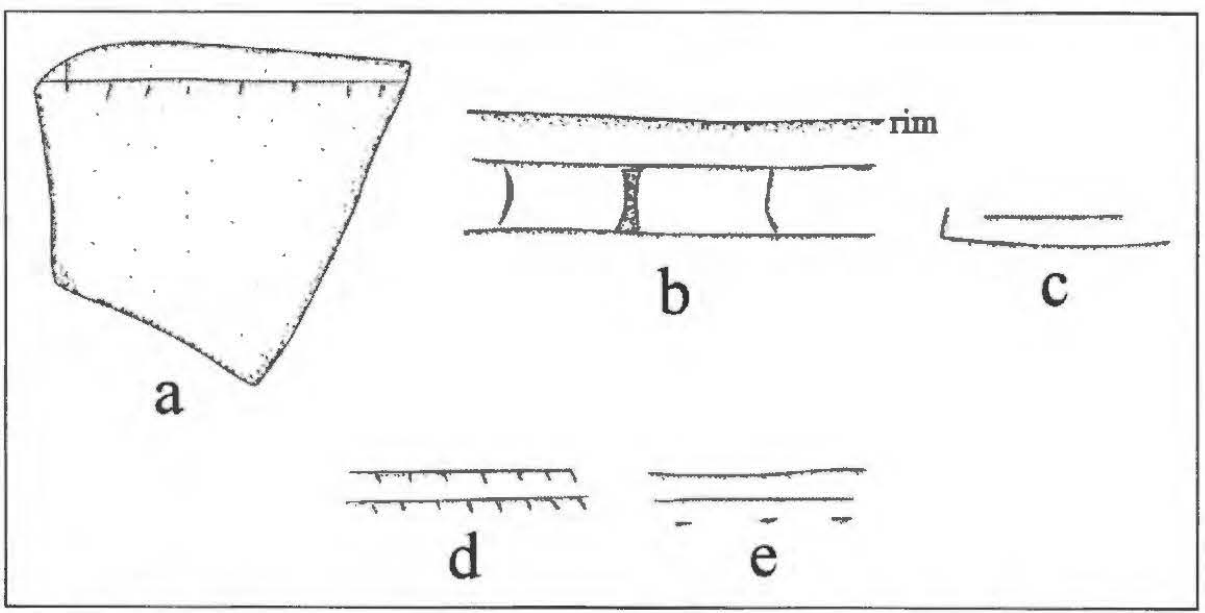

Figure 63. Simms Engraved decorative elements. Provenience: a, Feature 2, 50-L-3; b, Burial 66? fill; c-e, pre-WPA surface collection. 


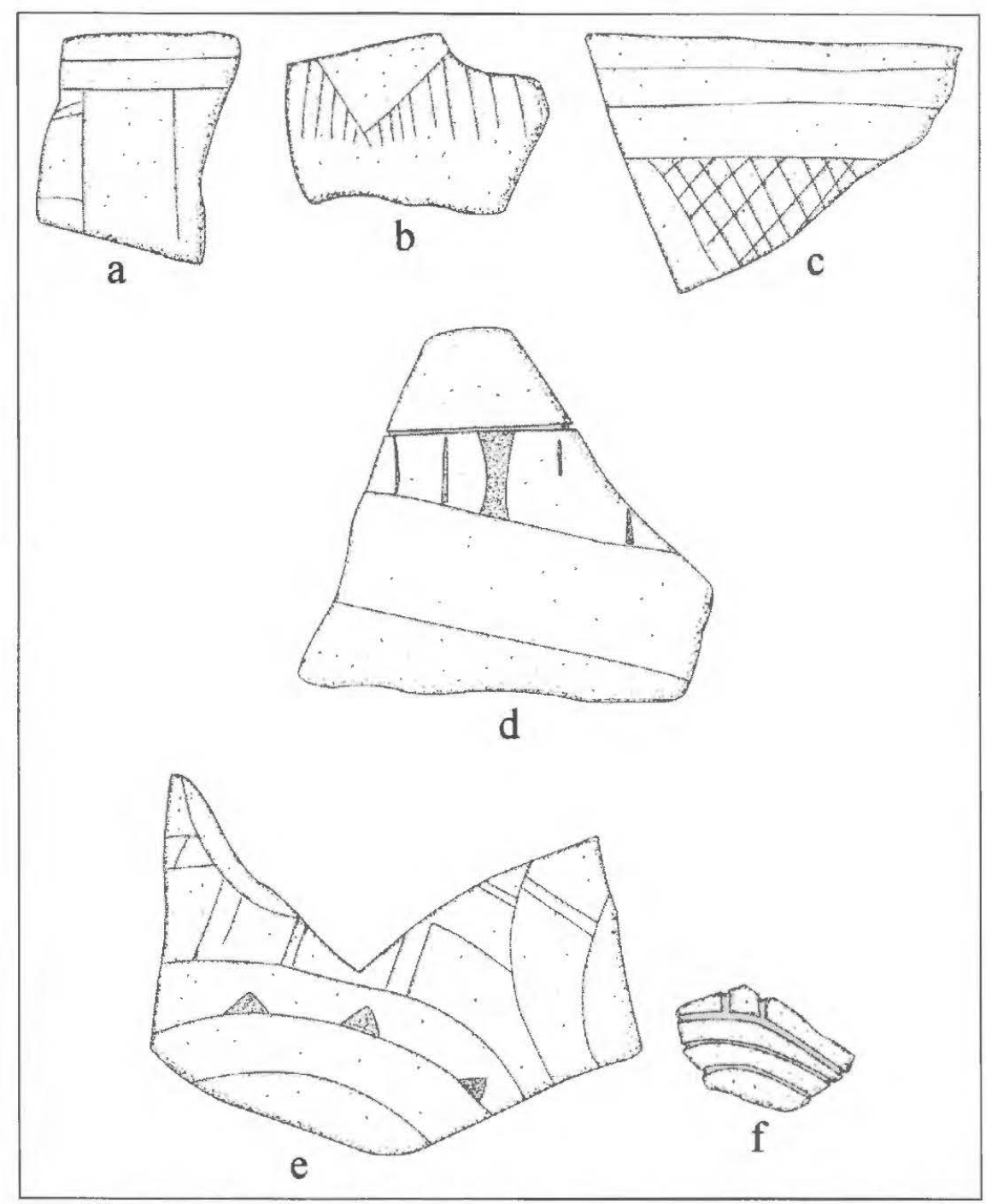

Figure 64. Other engraved and trailed decorative elements in the Mitchell site fine wares. Provenience: a, 40-L-2, layer 2; b, east side of cemetery, midden; c, 65-L-4, Iayer 3; d, Burial 51 fill; e, east side of cemetery, midden; f, General.

one of the principal fine wares in Middle Caddo period components along the Red River in Middle Caddo period (Haley phase) contexts.

There are sherds from Simms Engraved carinated bowls in the Mitchell site fine wares, including six lower rim sherds (Figure 63a, c-e); there is also a Simms Engraved rim from the fill of one of the burials (Figure 63b). These sherds have sharply and inwardly bent rims at the carination, almost forming a right angle on some vessels (Suhm and Jelks 1962:141 and Plate 71). Decorations include horizontal lines with tick marks on the rim panel (Figure 63a,d), horizontal engraved lines above a row of small excised punctates (Figure 63e), narrow horizontal panels (Figure 63c), and narrow engraved panels divided by vertical curvilinear lines and excised brackets (Figure 63b).

Two other engraved rim sherds are from Hempstead Engraved carinated bowls (see Suhm and Jelks 1962:Plate 35). One rim has multiple horizontal engraved lines circling the vessel, with large 
cross-hatched triangles pendant from the lowermost horizontal line (Figure 64c), while the other has large hatched pendant triangles (Figure 64b). Another sherd, from the lower panel of a compound bowl, has a slanted scroll motif (Figure 64d) that resembles certain Glassell Engraved vessels (Suhm and Jelks 1962:Plate 27c-d) from Louisiana Caddo sites.

One sherd, probably from a bowl, has a distinctive engraved design (see Figure 64e), but it cannot be identified as a currently defined Caddo ceramic type. The main part of the design are concentric curvilinear engraved lines with excised pendant triangles on one of the curvilinear lines. Curvilinear and vertical sets of engraved lines radiate out from the central and main part of the design. Its context in the midden deposits at the Mitchell site suggest this particular vessel sherd may date from cither Middle Caddo or pre-A.D. 1550 Late Caddo period deposits.

Approximately 28 percent of the engraved sherds in the Mitchell site ceramic assemblage from nonburial contexts are from bottles $(n=17)$. The stylistic diversity of the engraved bottles that were used and discarded at the site is considerable, although most feature curvilinear or opposed lines, along with different associated decorative elements (Table 10 and Figure 65). These associated decorative elements include open and excised pendant trianglcs (Figure 65g, k); hatched or cross-hatched zones (Figure 65b-c, $\mathrm{f}-\mathrm{g}, \mathrm{i}-\mathrm{j}$ ); tick marks (Figure 65e); and appliqued nodes (Figure 65g).

Table 10. Decorative elements on engraved bottle sherds.

\begin{tabular}{ll}
\hline Decorative element & $\mathrm{N}$ \\
\hline $\begin{array}{l}\text { Concentric circles with excised pendant triangles, diagonal opposed, and } \\
\text { cross-hatched zones }\end{array}$ & 1 \\
$\begin{array}{l}\text { Curvilinear lines } \\
\text { Curvilinear lines with open pendant triangles and parallel lines }\end{array}$ & 2 \\
Curvilinear and opposed lines & 1 \\
Horizontal cngraved lines & 1 \\
Opposed lines & 1 \\
Opposed lines and row of appliqued nodes & 1 \\
Opposed lines and zone of small concentric circles & 1 \\
Opposed lines and hatched zone & 1 \\
Opposed curvilinear lines and hatched-cross-hatched zone & 4 \\
Opposed curvilinear lines with tick marks and hatched zones & 1 \\
Parallel lines & 1 \\
\hline
\end{tabular}

Two or three bottle sherds are from Haley Engraved vessels (see Figure 65a, e), and another is from a Glassell Engraved bottle (see Figure 65c). Because of the nearly flat appliqued nodes on one bottlc sherd (see Figure 65d), another bottle sherd has been identified from a Hatchel Engraved vessel (cf. Suhm and Jelks 1962:67). Design element configurations on several others are consistent with their coming from other Hatchel Engraved bottles (see Figure 65b, f, h-j). 


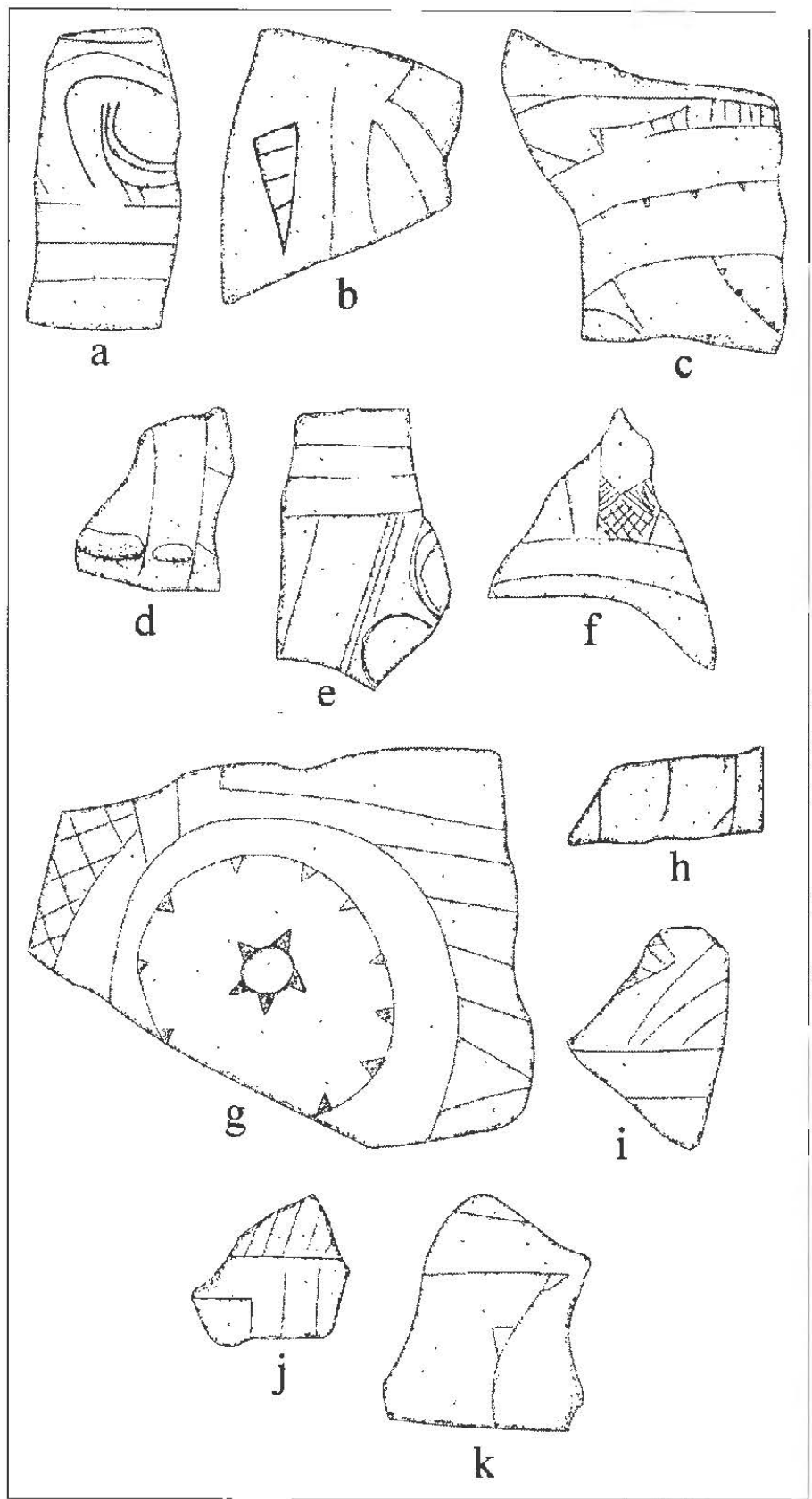

Figure 65. Engraved decorative clements on bottle sherds. Provenience: a, Burial 13 fill; b-d, unidentified provenience; e, east side of cemetery, midden: $f$, Burial 17 fill: g, surface in pothunter area; h, Feature 2, 55-L-2; i, Feature 2, 60-L-3; j, Feature 1, 25-L-4; k, Burial 50) fill

Both the engraved bowls/carinated bowls and bottles occasionally had either a red or a white clay pigment rubbed in the engraved designs. Only one bottle sherd ( 6 percent of the engraved bottle sherds) had a pigment in its design, and it was a white clay pigment. The use of pigments is mucl $\mathrm{m}$ e omm a in the engraved bowl and carinated bowl sherds, as 22 percent of these sherds has a pigment. $\mathrm{N}$ percent of these sherds have a white pigment $(n=9)$, compared to only one sherd ( 10 percent) with a red pigment. Approximately 2 percent of the engraved bowl and carinated bowl sherds we : also decorated 
with a red slip. One of the bottle sherds (7 percent), part of a Hatchel Engraved vessel section (see Figure 65b-c), has a black slip.

\section{Red-slipped}

All of the red-slipped sherds are from the bodies of grog-tempered vessels, most likely bowls and carinated bowls; none are clearly from bottles. Six sherds have a slip on both interior and exterior vessel surfaces; two others have only an exterior slip; and one body sherd has a slip only on the interior vessel surface.

\section{Trailed}

These trailed fine ware sherds are from Keno Trailed vessels. They include the following elements from bowls and bottles: curvilinear and opposed trailed lines $(n=1)$ (see Figure 64f); parallel trailed lines $(n=5)$; curvilinear trailed lines $(n=3)$; opposed trailed lines $(n=1$, from a bottle); and a straight trailed line $(n=1)$.

\section{Ceramic Sherd Comparisons between Hatchel Site Village Areas, the Hill Farm Site, the Eli Moores Mound Assemblage, and the Mitchell Site}

Village Plot 1 decorated sherds from the Hatchel site point to a primarily post-A.D. 1550-1600 occupation by Caddo peoples, as do ceramic sherds from Village Plot 2 and Burial Plots 1-4. Fine wares include a few sherds of Barkman Engraved (indicative of a pre-A.D. 1550 Caddo use of the area), as well as Belcher Engraved, Hodges Engraved, and Simms Engraved sherds. Utility ware sherds are from McKinney Plain, Cass Appliqued, Karnack Brushed-Incised, Emory Punctated-Incised, and Foster Trailed-Incised jars (Perttula 2014a).

Other excavations in the Hatchel village primarily recovered post-A.D. 1400 Texarkana phase ceramics (Areas I, III, IV, and V, see Perttula and Nelson 2003). These assemblages have decorated sherds from Simms Engraved, Keno Trailed, Foster-Trailed Incised, McKinney Plain or Belcher Ridged, and Barkman Engraved vessels (Perttula and Nelson 2003:Figure 25a-h and Figure 26a-d, g). More than 30 percent of the decorated sherds from the Hatchel village areas have trailed elements from Keno Trailed and Foster Trailed-Incised vessels, and such vessels are particularly common in Area I, Area III, and Area IV (see Perttula and Nelson 2003:Table 6). By contrast, trailed sherds are rare in Area II and Area V, suggesting that earlier village deposits are present in these parts of the Hatchel village. Engraved sherds from fine ware vessels are common in all village areas, most notably in Area I and Area V. Red-slipped sherds from carinated bowls (some shell-tempered) are restricted to Area I, Area III, and Area IV, while appliqued sherds from probable McKinney Plain vessels are present in Area II and Area V. Brushed, brushedincised, and brushed-appliqued sherds occur in low frequencies in Area I, II, III, and V, and each area is apparently part of, to some extent, the Late Caddo Texarkana phase village occupation.

One area (Area II) in the Hatchel village has distinctive earlier incised, punctated, and incised-punctated ceramic decorative styles (Perttula and Nelson 2003:Figure 26e-f, h-i, k); these ceramics are also associated with 11-13th century radiocarbon dates from the archaeological deposits. The most distinctive decorated sherds from these early Caddo contexts at Hatchel have large impressed or circular punctations (see Perttula and Nelson 2003:Figure 26j-k), and are probably from Crockett Curvilinear Incised vessels (see Suhm and Jelks 1962:Plates 16e and 17h-i). There is also another sherd from this area (see Perttula and Nelson 2003:Figure 26f) that may be from a Crockett Curvilinear Incised bowl or carinated bowl. The incising decorative element on this sherd appears to be an incised triangular element that is part of a scroll design. A carinated bowl with the same scroll design - but also accompanied by incised circles filled with circular punctations between the scrolls - was recovered from Floor $\mathrm{K}$ underneath the Hatchel mound (Laughlin 
1940:42; cf. Suhm and Jelks 1962:Plate 17b, m). Similarly, the zoned incised-small circular punctated sherds from Area II (see Perttula and Nelson 2003:Figure 26h-i) also resemble Crockett Curvilinear Incised or Pennington Punctated Incised decorative motifs (cf. Suhm and Jelks 1962:Plates 17j-k, t and 61d-e).

The two occupation areas at the Hill Farm site (41BW169), not far southeast of the platform mound at the Hatchel site, appear to have decorated sherd assemblages also indicative of ca. post-A.D. 1550 occupations during the latter part of the Texarkana phase (Perttula et al. 2008:96-97; Sundermeyer et al. 2008:228, 235-236). The principal fine wares in the Hill Farm assemblage include Keno Trailed ( $n=17$ sherds), Hodges Engraved ( $n=13)$, Glassell Engraved ( $n=12)$, Simms Engraved $(n=2)$, and Simms or Avery Engraved ( $n=5)$. Identified utility wares include Karnack Brushed-Incised ( $n=12$ sherds), Foster Trailed-Incised $(n=3)$, Nash Neck Banded $(n=3)$, and McKinney Plain $(n=3)$. Less than 2 percent of the sherds from the site are tempered with either shell or bone (Perttula et al. 2008:Table 1).

The Eli Moores site was apparently also occupied primarily during the latter part of the Texarkana phase, perhaps as late as the late 17th to early 18th century A.D. Principal utility ware sherds have incised, brushed, appliqued, punctated, and trailed-incised decorative elements from Emory PunctatedIncised, Foster Trailed-Incised, Karnack Brushed-Incised, and McKinney Plain vessels. There are also Nash Neck Banded and Belcher Ridged sherds in the utility wares (Perttula 2014b). The fine ware sherds are principally from Barkman Engraved and Simms Engraved vessels, as well as red-slipped and Keno Trailed bowls and bottles. Sherds from Simms Engraved ( $n=170$, including many sherds from the later hubcap-style vessel form) and Barkman Engraved ( $n=80)$ vessels dominate the fine wares from the Eli Moores sites. Other identified fine ware engraved ceramic types in the assemblage include Avery Engraved, Belcher Engraved, Natchitoches Engraved, Hodges Engraved, Hatchel Engraved, Taylor Engraved, and Glassell Engraved. Only the Barkman Engraved, Hatchel Engraved, and Simms Engraved fine wares were likely produced locally by Red River Caddo potters, but the other defined ceramic types were likely produced by contemporaneous Great Bend Belcher phase Caddo potters living downstream along the Red River and major tributaries.

\section{Ceramic Spindle Whorl}

The one ceramic spindle whorl made from a base sherd was recovered in the midden deposits (FS 101). The spindle whorl is $99.2 \mathrm{~mm}$ in diameter and has a $11.0 \mathrm{~mm}$ central perforation (Figure 66).

\section{Chipped Stone Tools and Debris}

A 1932 surface collection from the Mitchell site ("the Old Mitchell Place") has a number of chipped stone tools, including five bifaces and eight dart points. The bifaces consist of four biface preforms of dark gray chert, dark brown chert, red jasper, and brown jasper, and a biface fragment of gray chert. The biface preforms range from $9.7-15.0 \mathrm{~mm}$ in thickness.

\section{Dart Points}

The dart points in the Old Mitchell Place collection are indicative of Late Archaic (ca. 5000-2500 years B.P.) and Woodland (ca. 2500-1150 years B.P.) use of the site area. The one Late Archaic point is a Trinity point made from a dark brown chert. The Woodland period dart points include one Kent dart point, five Gary points, and one Gary point preform. The Kent point is made from a light gray novaculite. Two of the Gary points have flat bases, stem widths of $21.5-22.1 \mathrm{~mm}$, and $8.0-9.0 \mathrm{~mm}$ thicknesses. The other three Gary points have rounded bases, relatively narrow stem widths $(15.2-19.0 \mathrm{~mm})$ and blade thicknesses that range from $6.0-9.1 \mathrm{~mm}$. The one Gary point preform is made from a heat-treated gray 


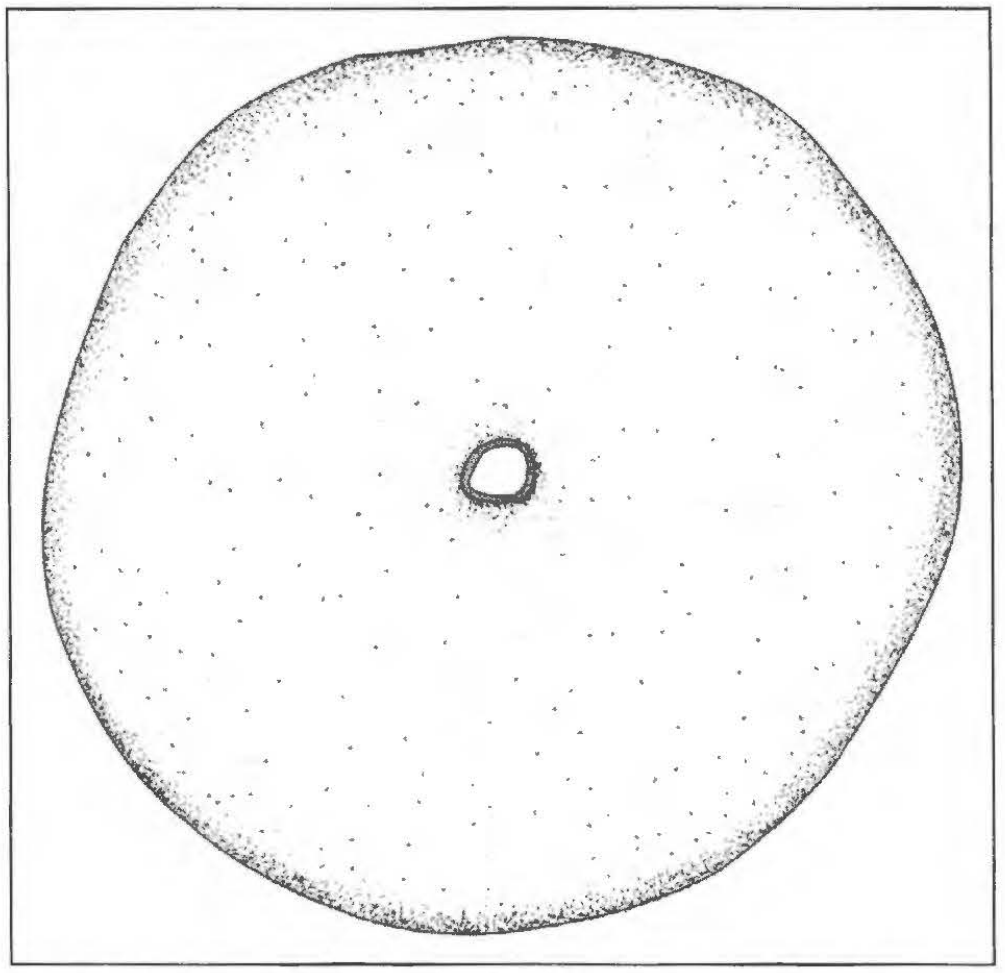

Figure 66. Ceramic spindle whorl from the midden at the Mitchell site.

novaculite, and has a $26.2 \mathrm{~mm}$ stem width and a blade thickness of $9.0 \mathrm{~mm}$. The Gary points are made from a dark grayish-brown chert $(n=1)$, a black chert $(n=1)$, a light gray chert $(n=2)$, and a brownish-red jasper $(n=1)$.

In addition to these artifacts, a few chipped and ground stone tools and debris were recovered in the fill of Burials 48, Burial 50, and Burial 51. The stone artifacts in Burial 48 include a sandstone grinding slab fragment $(80.6+\mathrm{mm}$ in length), a greenstone celt resharpening flake, brown jasper and quartzite cores, and a cortical flake of brown novaculite. In Burial 50's fill was a single platform gray novaculite core and a gray chert cortical flake. A unifacial flake tool of brown jasper came from the fill of Burial 51.

\section{Ground Stone Tools}

A celt with a bifacial bit and a polished body was placed as a funerary offering in Burial 66 (Figure 67); it is made from a Ouachita Mountains fine-grained greenstone. The tool is $90.3 \mathrm{~mm}$ in length, 39.2 $\mathrm{mm}$ in width, and $16.1 \mathrm{~mm}$ thick. The bit width is $35.2 \mathrm{~mm}$, and the height of the bit is $14.9 \mathrm{~mm}$.

\section{Unmodified Pebbles}

There are 35 small rounded chert and quartz pebbles in Burial 63 that are associated with a turtle shell rattle or rattles. These small pebbles were found with two concentrations $(n=29$ and $n=127$ pieces) of turtle shell fragments. 


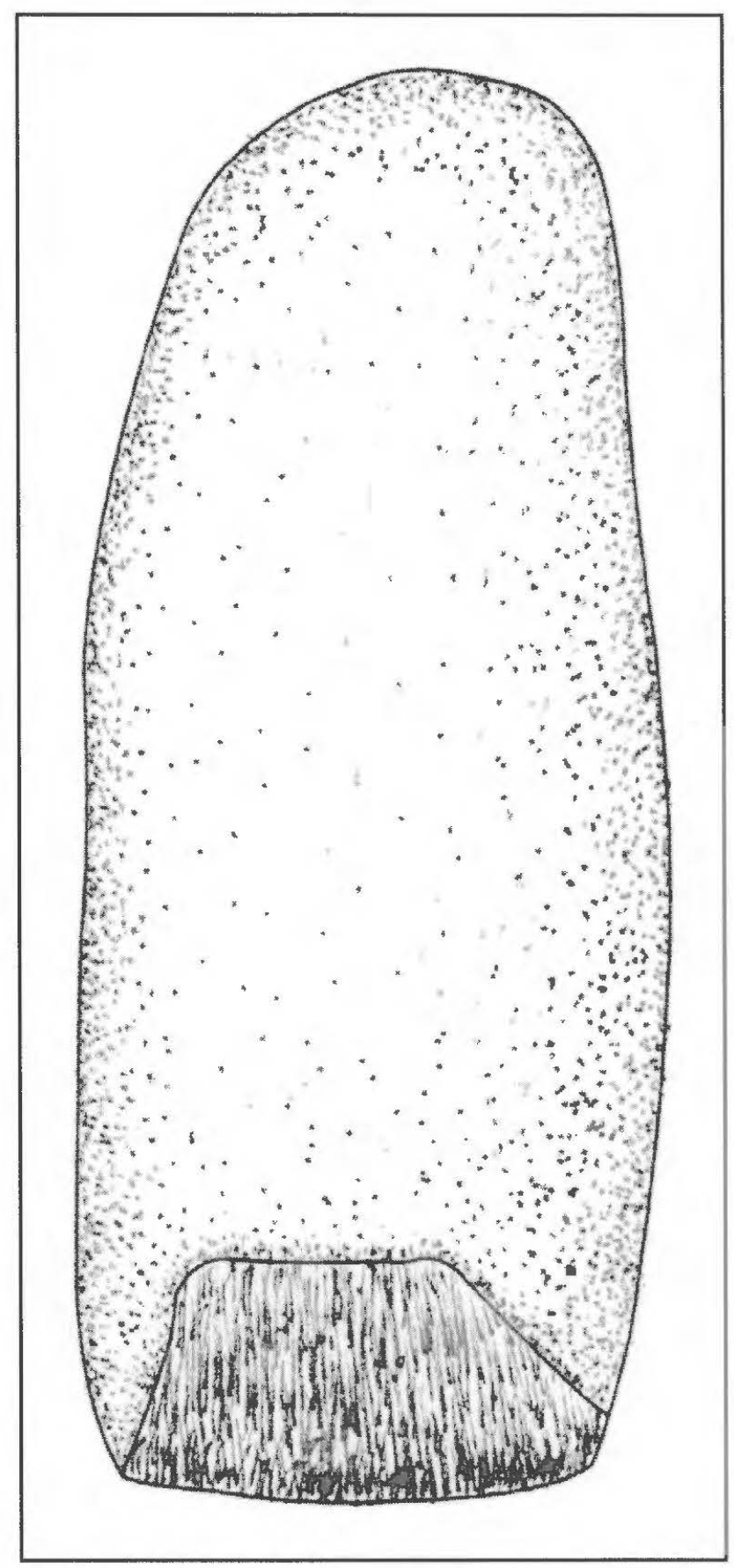

Figure 67. Celt from Burial 66.

\section{Bone and Antler Tools}

Excavations in the midden deposits on the east side of the cemetery recovered a number of antler tools. One of the tools is a perforated antler beam base, $26.9 \mathrm{~mm}$ in diameter; there are three antler base fragments (24.0-36.1 $\mathrm{mm}$ in diameter); a $285 \mathrm{~mm}$ long antler beam with two antler tines (65-L-4, layer $3)$; and three antler tine distal fragments; these have maximum diameters that range from $8.5-13.8 \mathrm{~mm}$. There is also a near complete antler tine tool with a rounded end (Figure 68). This tool is $139.2 \mathrm{~mm}$ in length and has a maximum diameter of $18.4 \mathrm{~mm}$. 


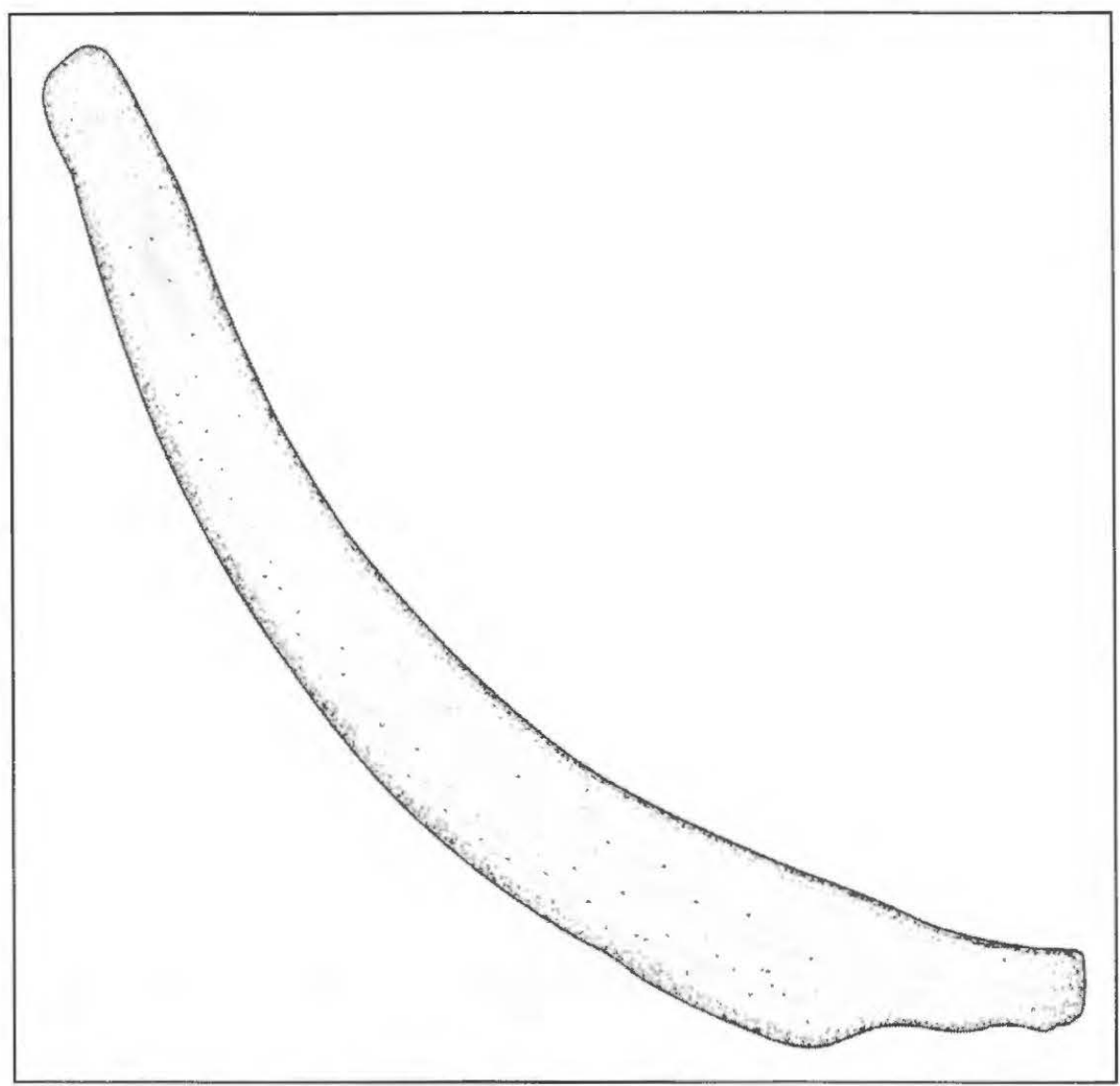

Figure 68. Antler tine tool (6-2-180).

There are four deer ulna awls, complete $(n=1)$ and fragmentary $(n=3)$ (Figure 69). The complete ulna awl is $157.0 \mathrm{~mm}$ in length, and the maximum width of the three awls ranges from $33.7-37.3 \mathrm{~mm}$. One of the fragmentary bone awls $(13.0 \mathrm{~mm}+$ in length and $8.2 \mathrm{~mm}$ in width), from Burial 66 , has serrated edges.

Two polished bone pins, one whole (Figure 70) and one fragmentary, are in the Mitchell site artifact assemblage. The whole pin (6-2-157, Burial 66) is $146.9 \mathrm{~mm}$ in length and a maximum of $4.8 \mathrm{~mm}$ wide mid-point on the bone shaft.

One bone needle fragment was a funerary offering in Burial 6B. It is at least $60.3 \mathrm{~mm}$ in length and $1.7 \mathrm{~mm}$ in diameter.

A distinctive bone tool in the assemblage is a fish bone needle; the bone tools are made from catfish spines. The fish bone needles, all from Feature $2(n=3)$, are polished from one end to the sharpened tip (Figure 7la-b). The needles range from $47.0-54.0 \mathrm{~mm}$ in length.

\section{Bone Bead}

A single burned bone bead was found in the midden deposits. The bead is made from a drilled piece of deer antler, and is $46.0 \mathrm{~mm}$ in length and $12.9 \mathrm{~mm}$ in exterior diameter. The drilled hole is $3.1 \mathrm{~mm}$ in diameter. 


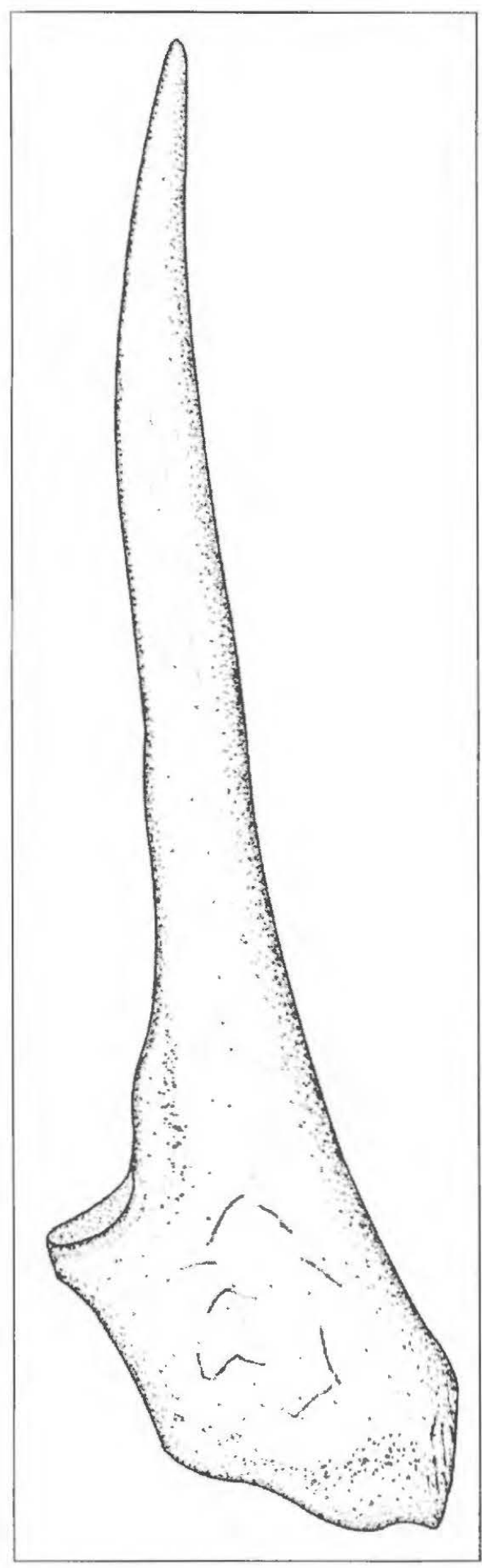

\section{Figure 69. Deer ulna awl from Feature 4} at the Mitchell site.

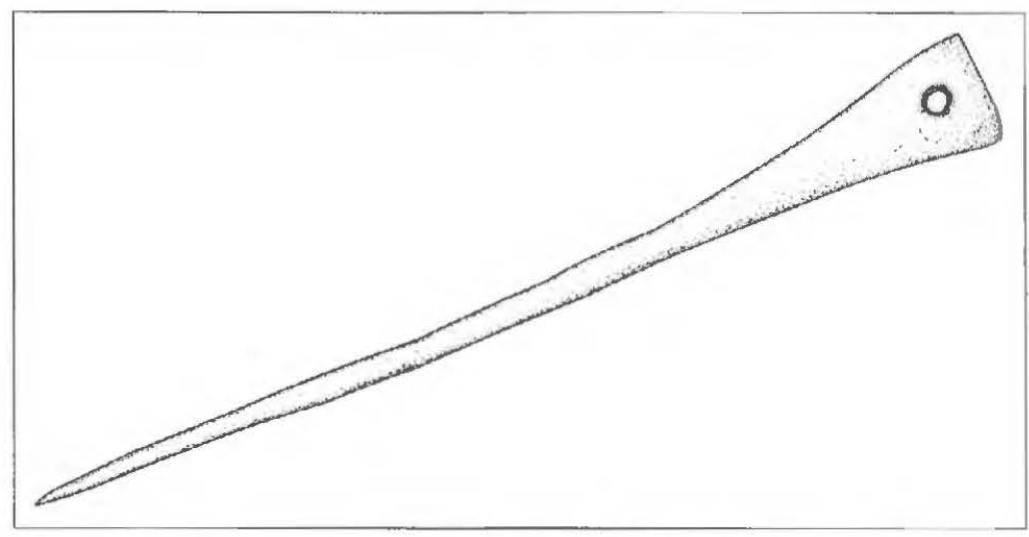

Figure 70. Polished bone pin from the Mitchell site.

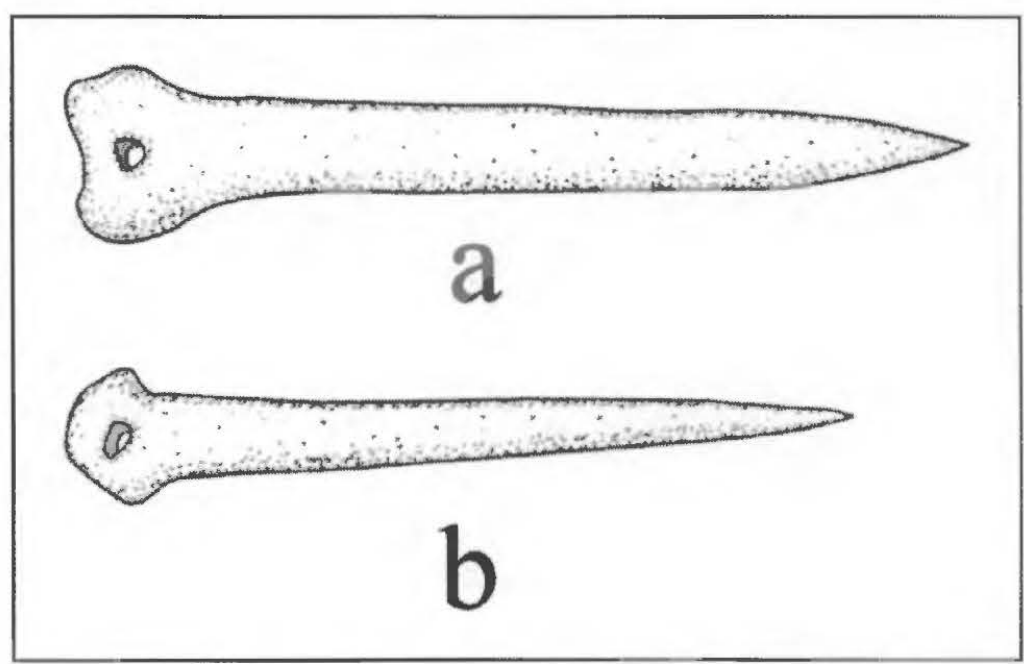

Figure 71. Fish bone needles: a, 55-L-2 (Feature 2); b, 60-L-3 (Feature 2).

\section{Mussel Shell Hoes}

There are a number of sturdy mussel shell hoes and hoe fragments recovered from excavations in the midden deposits on the northwestern and east side of the cemetery. Two mussel shell hoes came from the northwest side of the cemetery; they have single perforations that range from 17.0-18.5 mm in diameter (Figure 72a). There are three complete hoes and two hoe fragments from the midden deposits on the east 


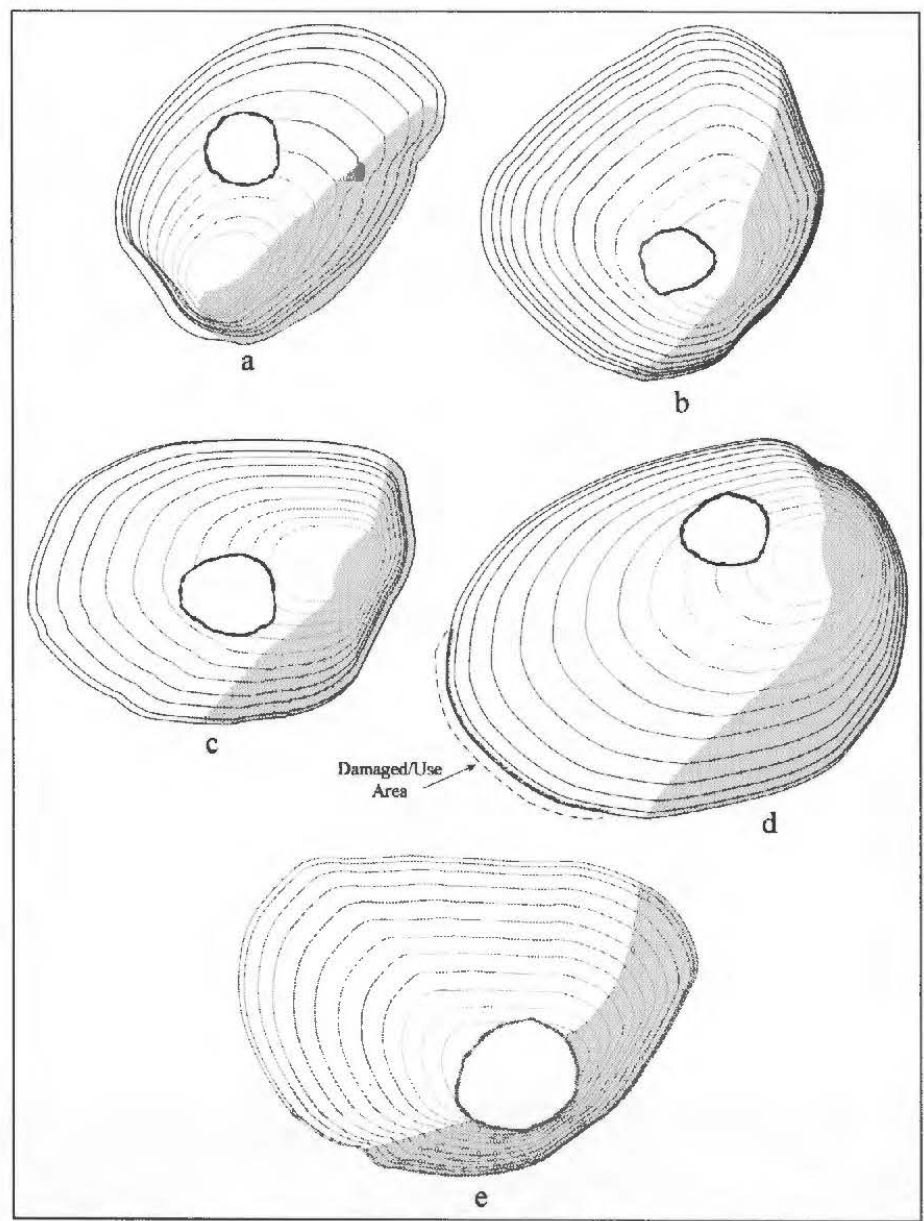

Figure 72. Mussel shell hoes from the Mitchell site: a, northwest side of the cemetery (6-2-125); $b$, east side of cemetery (6-2-172, Burial 48); c-d, 6-2-124 (midden); e, Burial 12.

side of the cemetery: they have perforations that range from 13.9-18.0 mm (Figure 72b). A mussel shell hoe was a funerary offering in Burial 12 (Figure $72 \mathrm{e}$ ). It is $102.0 \mathrm{~mm}$ in length and has a large $(28.3 \mathrm{~mm})$ perforation near the umbo.

There are seven other shell hoes from other excavated midden contexts at the site (6-2-126, 6-2-124, and Mitchell-5). These have single perforations that range from 14.6-23.3 mm in diameter (see Figure 72c-d). Finally, a complete mussel shell hoe is in the W. H. Mathews, Jr. collection (Burial 9, see Table 1) from the 1935 excavations at the Mitchell site; it has an $18.2 \mathrm{~mm}$ perforation.

\section{Other Mussel Shell Artifacts}

The Mitchell site collection also has two unmodified mussel shell valves (6-2-86 and 6-2-135) from Burials 32 and 54, and two unmodified mussel shell valve fragments in Burial 36. 


\section{Marine Shell Beads}

There are four different kinds of marine shell beads in the Mitchell site assemblage. The first are tubular or disk-shaped conch shell beads $(n=91)$ with a central perforation; these have two ranges in size, one group from 3.0-3.9 mm in length and diameter and a second group from 5.1-12.2 mm in length and diameter; these come from Burial $29(n=18)$, Burial $30(n=5)$, Burial $19(n=2)$, and Burial $69(n=63)$. The second kind of marine shell bead is barrel-shaped conch columella beads $(n=63)$ with a drilled opening at either end. These beads range from 11.0-27.0 mm in length and 6.2-13.2 $\mathrm{mm}$ in diameter; they come from Burial $7(n=5)$, Burial $19(n=8)$, Burial $32(n=20)$, and Burial $36(n=9)$. The third kind of marine shell bead is oval-shaped Olivella beads $(\mathrm{n}=6)$, with openings at either end. These beads range from 12.0-15.9 $\mathrm{mm}$ in length and 5.0-6.0 mm in diameter. The fourth kind are very small (2.0-2.6 $\mathrm{mm}$ in diameter) diskshaped Olivella beads $(\mathrm{n}=5)$ from Burial 43.

\section{Marine Shell Gorgets}

A marine shell gorget (102.5 $\mathrm{mm}$ in length and $111.2 \mathrm{~mm}$ in width) was one of the funerary offerings in Burial 19. The outer margins of the gorgets have 15 petal-shaped or scalloped elements, two of which at the top have drilled $4.0 \mathrm{~mm}$ diameter perforations (Figure 73). Proceeding from the inner edge of the petals to the center of the gorget, which is marked by a drilled circle, is a circular band filled with drilled dots; then an open circular band; and then a circle with a smaller central circle with a drilled circle. Radiating from the central circle are three excised curvilinear lines or volutes, and the design has a triskele structure (Brain and Phillips 1996:7).

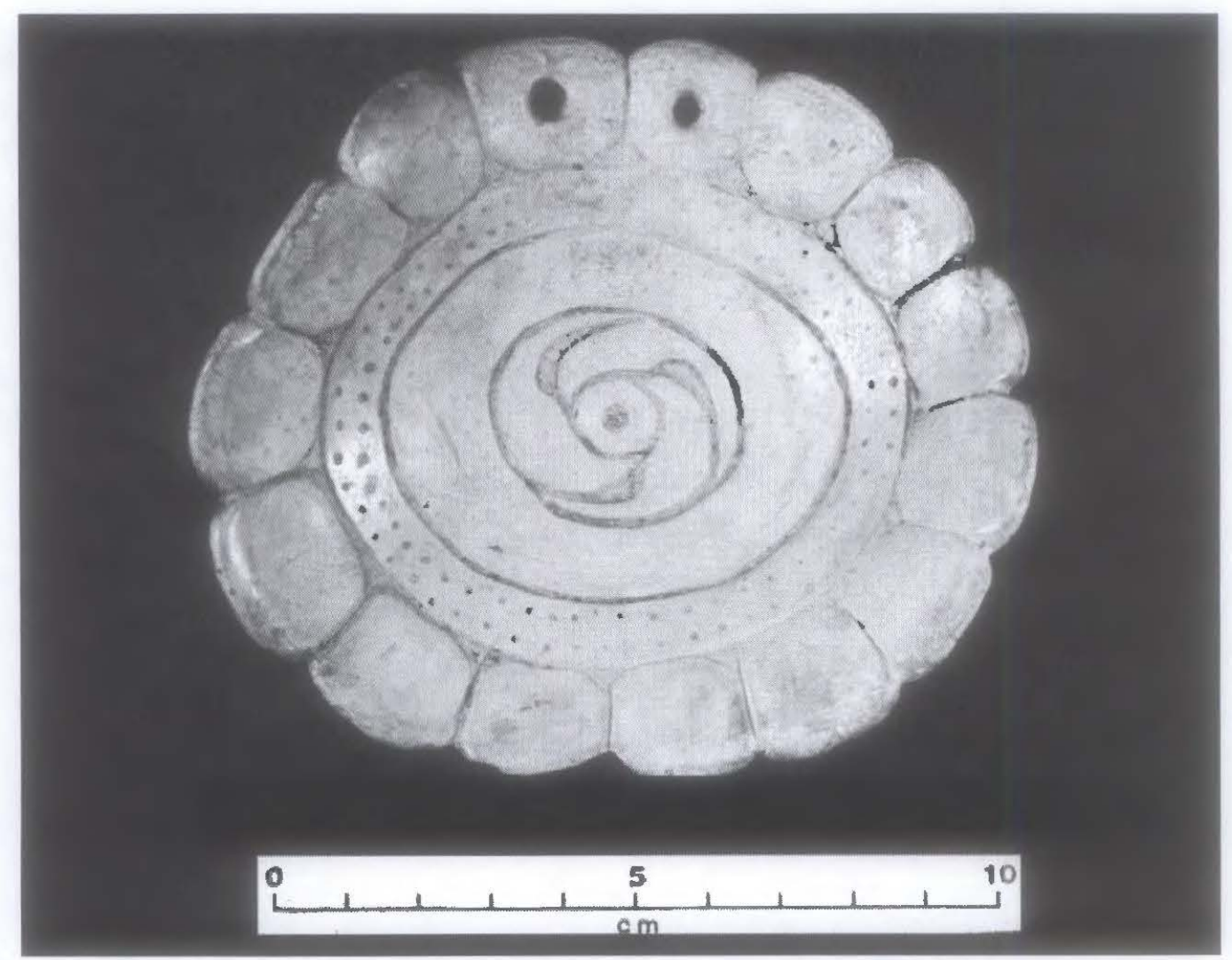

Figure 73. Marine shell gorget from Burial 19 at the Mitchell site. 
Very similar engraved gorgets have been recovered from a burial in the shaft tomb at the Sam Kaufman site (41RR16) (see Skinner et al. 1969:Figure 31c) on the Red River, in a burial at the Foster Place on the Red River in southwest Arkansas (Brain and Phillips 1996:121), and in a burial at the Kirkham site (3CL29) (Etchieson 1981; see Brain and Phillips 1996:121) in the mid-Ouachita River ba$\sin$. One of the burials in the shaft tomb at Sam Kaufman has been radiocarbon-dated to cal. A.D. 14121511 (Perttula 2008:Figure 6), suggesting the likely age range of this gorget from the Mitchell site.

Brain and Phillips (1996:113) classify gorgets with this style of decoration as the Triskele style, previously referred to as the Nashville Scalloped Triskele style. These gorgets have a Nashville basin provenance in the Ohio River basin (Brain and Phillips 1996:116, 120). The Mitchell site gorget differs from the defined styles within the broader Triskele style, however, in that the circular band does not contain concentric circles within it.

A second marine shell gorget was recovered from a burial excavated by Glenn Martin in 1936 at the Mitchell site. This gorget, $78.2 \times 80.1 \mathrm{~mm}$ in length and width, has two drilled holes $(3.8 \mathrm{~mm}$ in diameter) at the top, as well as a distinctive engraved design on the interior surface of the shell (Figure 74). It has two engraved circles ( 30.0 and $62.4 \mathrm{~mm}$ in diameter), the innermost with a cruciform design (cf. Brain and Phillips 1996:25) outlined by hatched triangular areas. At the center of the cruciform is a small excised dot. The outer circle has a series of hatched pendant triangles whose apexes point towards the inner engraved circle.

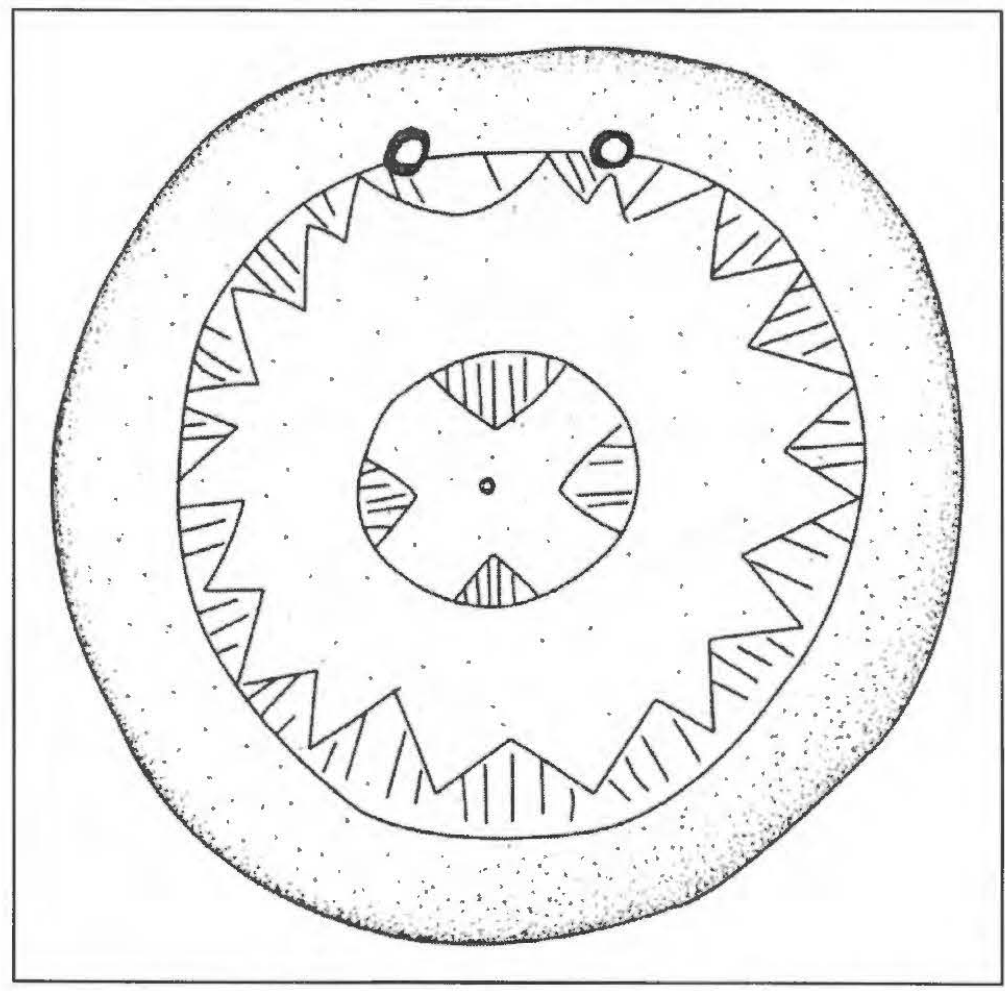

Figure 74. Engraved cruciform style marine shell gorget from the Mitchell site. 


\section{Perforated Human Teeth}

Certainly among the most distinctive artifacts found at the Mitchell site are 12 perforated adult-sized human teeth (Figure 75a-d): four molars and eight incisors. The molars range from 19.0-21.0 mm in length and have $0.8-2.0 \mathrm{~mm}$ perforations. The incisors, on the other hand, range from $21.2-27.0 \mathrm{~mm}$ in length and have $0.6-1.0 \mathrm{~mm}$ perforations. The perforated teeth may have been worn in a necklace.

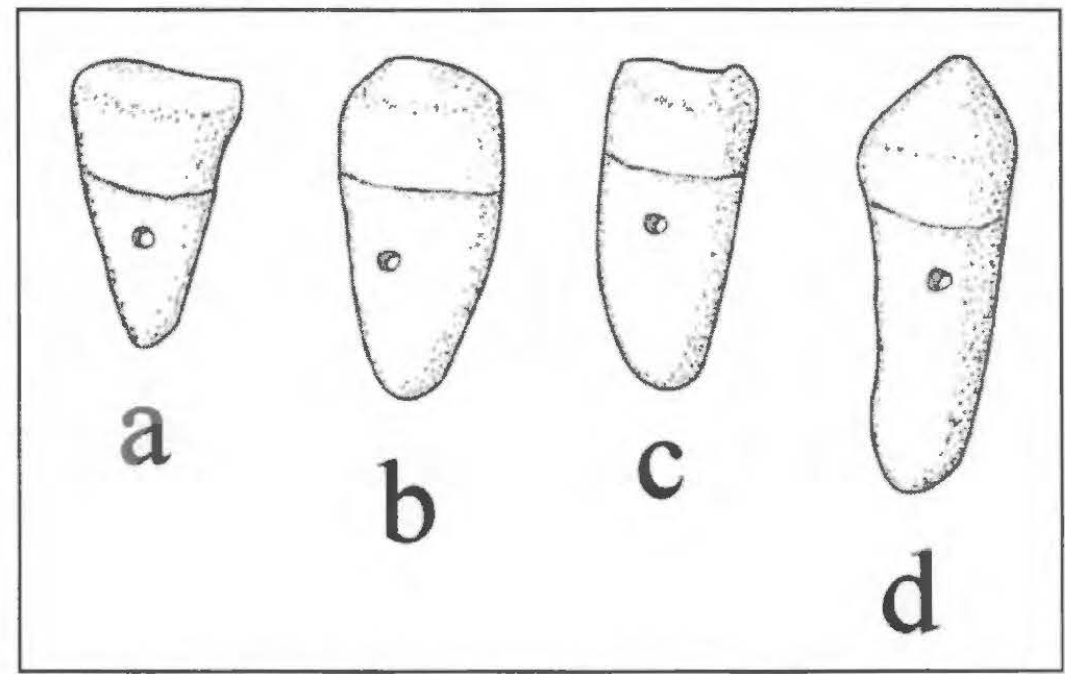

Figure 75. Perforated human teeth: a-b, molars; c-d, incisors.

\section{Animal Bones}

Animal bones are apparently well-preserved at the Mitchell site, but unless they were a tool or tool fragment, they were only collected in the UT excavations from the fill of a number of the burials. These include:

- Burial 19, 28 bird bones found in one of the vessels in the grave;

- Burial 48,35 animal bones and teeth, including bones and teeth of deer;

- Burial 50,3 animal bones;

- Burial 52,100+ turtle shell fragments found beneath the left arm and hand of the deceased; 10 passenger pigeon bones found in one of the vessels in the grave.

- Burial 54,19 animal bones found beside and within one of the vessels in the grave; and

- Burial 66, 36 squirrel bones found within and beside the mouth of one of the vessels in the grave; 11 deer foot bones.

Although generally rare in ancestral Caddo faunal assemblages, bones from passenger pigeons, an extinct species, were quite common in Late Caddo period contexts at the Hughes Mound site (3SA11) in the Ouachita River basin (Mary Beth Trubitt, December 2013 personal communication). Passenger pigeon bones are also present in both ca. A.D. 1450-1500 and A.D. 1650-1700 deposits at the Hardman site in the Ouachita River basin (Early 1993:147, 150). Additionally, passenger pigeon bones $(n=14)$ have been found at the Late Caddo McCurtain phase village at the Roden site along the Red River (Perino 1981). There is one passenger pigeon left humerus from Zone $\mathrm{H}$ in the platform mound at the Hatchel site (41BW3) (Darrell Creel, December 2013 personal communication; April 24, 1975 letter from Lyndon L. Hargrave on file at TARL), less than a mile north of the Mitchell site. Bones from a single passenger pigeon have been recovered at the ca. A.D. 1650-1710 MeLelland site (16BO236) on the Red River (Kelley 1997:103). 
At the Crenshaw site on the Red River in southwest Arkansas, passenger pigeon bones $(\mathrm{n}=75)$ are abundant on the floor in Feature 6, the antler temple (Jackson et al. 2012:Table 3-1), and in the midden surrounding the antler temple. The antler temple deposits date at 2 sigma to between A.D. 1161-1254, calibrated (John Samuelson, December 2013 personal communication). The bones of at least 27 passenger pigeons have been recovered in roughly contemporaneous contexts at the George $\mathrm{C}$. Davis site (41CE19), in a large trash pit in one of the village areas (Thurmond and Kleinschmidt 1979:92). Passenger pigeon bones $(n=2)$ were present in Burial 90 in the Great Mortuary at the Spiro site in eastern Oklahoma (Brown 1996:706), along with 10 turkey wing fan bones. This burial features dates from ca. A.D. 1350-1450, during the Spiro IV interval. Two passenger pigeon bones were recovered from Burial 2 at the Tyson site (41SY92) in a mid-14th to mid-15th century Caddo context (Tom Middlebrook, December 2013 personal communication).

The earliest example of passenger pigeon use in East Texas is a passenger pigeon faunal element that has been recovered in Woodland period contexts (ca. 2500-1200 years B.P.) at the Spike site (41DT 16). This midden site is in the upper Sulphur River basin (Fields et al. 1993).

Although not a Caddo site, passenger pigeon bones were relatively common in 8th-10th century midden deposits in Mound S at the Toltec site in the central Arkansas River valley (Kelly 2012:141), and other Woodland and Mississippian period sites in Northeast Arkansas, including Zebree, Knappenberger, and Ridge House (David H. Jurney, December 2013 personal communication) and elsewhere in the state. A single passenger pigeon bone has been recovered in a refuse pit at the Poverty Point site in Northeast Louisiana (http://www.passengerpigeon.org/states/Louisiana.html), and at the famous Mississippian site of Cahokia in southern Illinois (Parmalee 1957).

Passenger pigeons were likely present in roosting areas in winter months along the Red River (cf. Kelly 2012:141), and there are 19th century accounts of roosts in the Ft. Smith, Arkansas area. 


\section{CHAPTER 4, AGE OF THE SITE AND CULTURAL AFFILIATION}

\section{Age of the Site}

The analysis of the ceramic vessels placed in the many Caddo burials at the Mitchell site, as well as the analysis of the decorative methods and elements on the decorated sherds from midden excavations and burial fill, indicate that there were two principal periods of Caddo settlement at the site: during the Haley phase, and then later during the Texarkana phase.

The Haley phase (ca. A.D. 1200-1400) component at the Mitchell site is marked by an extensive midden deposit and habitation features as well as a number of burials (Figure 76). The ceramic set associated with Haley phase sites includes Dunkin Incised, East Incised, Friendship Engraved, Haley Complicated Incised, Haley Engraved, Handy Engraved, Hempstead Engraved, and Pease Brushed-Incised.

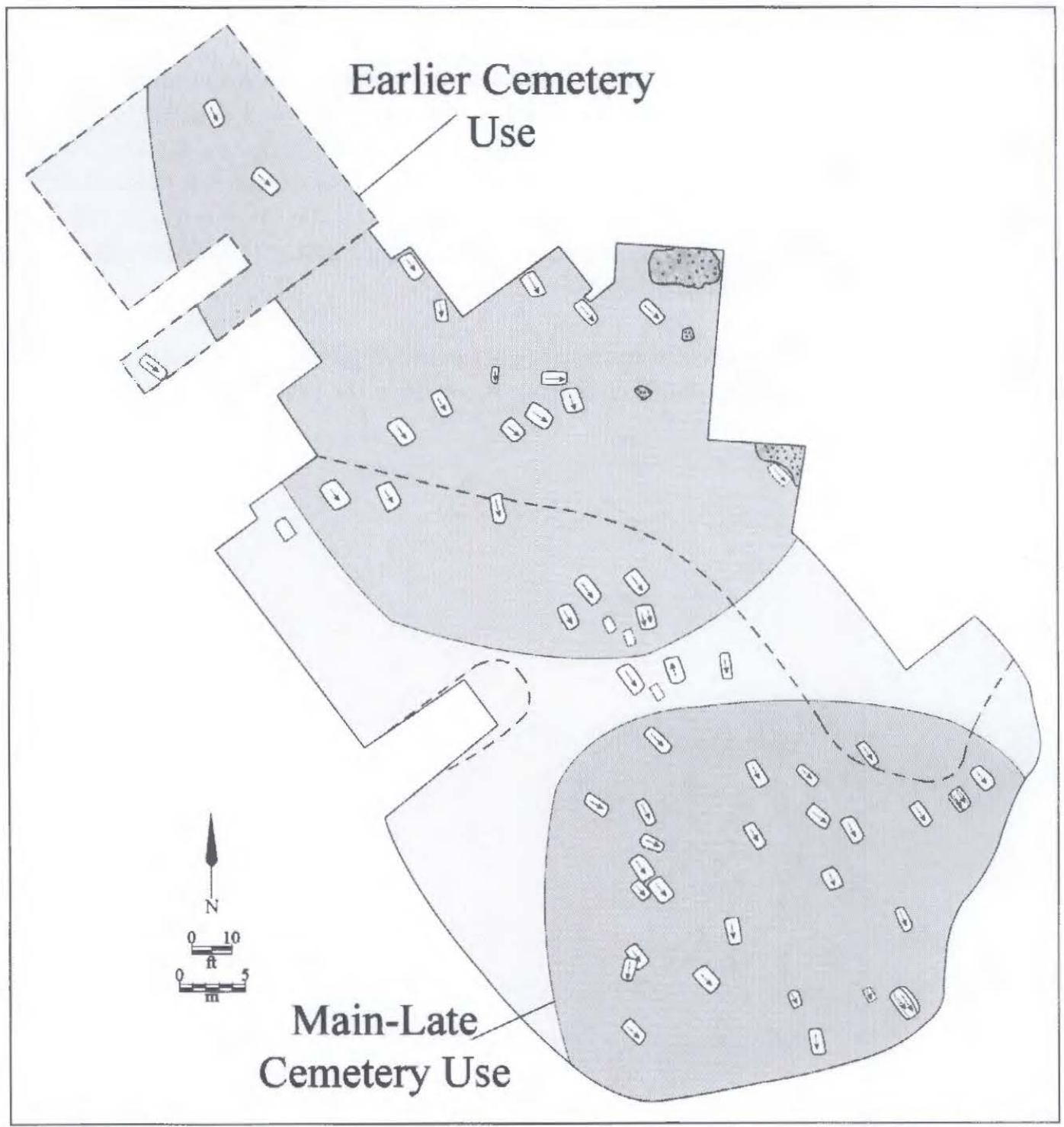

Figure 76. Earlier and Main Late periods of cemetery use at the Mitchell site. 
The later use of the Mitchell site during the Texarkana phase dates after ca. A.D. 1400 to the latter part of the 17th century, based on calibrated radiocarbon dates from the nearby Eli Moores (41BW2) and Hatchel (41BW3) sites (Perttula 2014a, 2014b); both sites have important Texarkana phase components with constructed mounds. The recovery of Texarkana phase ceramic sherds in the midden deposits indicates that the Mitchell site had habitation areas during this time, but the most distinctive part of the Tcxarkana phase component is the large cemetery at the southern end of the site (see Figure 76). The Texarkana phase ceramic set includes Avery Engraved, Barkman Engraved, Bowic Engraved, Foster TrailedIncised, Hatchel Engraved, Karnack Brushed-Incised, Keno Trailed (in the latest part of the phase), McKinney Plain, Moore Noded, Nash Neck Banded, Pease Brushed-Incised (in the earliest part of the phase), and Simms Engraved (in the latest part of the phase).

\section{Radiocarbon Sample}

A single radiocarbon sample has been submitted for dating from the Mitchell site. The sample consists of charred organic residue scraped from the exterior surface of a Dunkin Incised ceramic body sherd from the eastern part of the midden deposits. The charred organic residue was analyzed by DirectAMS (D-AMS 005274). Its delta $13 \mathrm{C}$ ratio is -17.7 parts per million.

The conventional age of the charred organic residue is $837 \pm 29$ B.P. The sample was calibrated using OxCal v4.2.3 and the IntCal 13 atmospheric curve. At 1 sigma, the most likely calibrated age range of the charred residue is A.D. 1169-1224 (0.62), while at 2 sigma. there is a 95 percent chance that the organic residue dates from A.D. 1158-1262; the median calibrated agc is A.D. 1207. This calibrated age range is consistent with the range of decorated sherds found in the extensive midden deposits at the Mitchell site, as well as with the distribution of earlier Middle Caddo period burials in the cemetery (see Figure 76).

\section{Cultural Affiliation}

The Middle Caddo period component at the Mitchell site is affiliated with the Haley phase, dating to ca. A.D. 1200-1400 based on radiocarbon dates (see Samuelsen 2014) and the seriation of ceramic decorative styles. Because of a number of excavations over the last 100 years or so, this is a fairly well understood ancestral Caddo archaeological phase marked by mound centers (such as the Battle, Crenshaw, and Haley sites) - both platform and burial mounds - large off-mound cemeteries, and large dispersed communitics comprised of villages, hamlets, and farmsteads along the Red River both upstream from and in the Great Bend arca of the Red River in Southwest Arkansas and the northeastern-most part of East Texas (Figure 77). The ncarby Halchel and Cabe (4IBW 14) sites have Haley phase village deposits and/or burials, but the mounds at both sites were constructed after ca. A.D. 1400 in the Texarkana phase.

The later ancestral Caddo occupation at the Mitchell site - principally marked by a large cemeteryis a component of the Late Caddo period Texarkana phase (ca. A.D. 1400-1690). Sites belonging to this phase are found on the Red River in Southwest Arkansas and Northeast Texas above the Great Bend of the Red and on the lower Sulphur River (Figure 78). The Hatchel site as wcll as the nearby Eli Moores (4IBW2) and Cabe sites are major components of the Texarkana phase, with both constructed mounds and extensive village habitation deposits (see Perttula 2014a, 2014b; Perttula ct al. 1995). All three sites, as well as the Mitchell site, may be part of an extensive Nasoni Caddo village that was visited by the Spanish in 1691. 




Figure 77. Important Middle Caddo sites, major Red River Caddo centers occupied during the Middle Caddo period, and defined Middle Caddo period phases. 1, Harling (41FN1); 2, Sanders (41LR2); 3, Fasken (41RR14); 4, Roitsch (41RR16); 5, Holdeman (41RR11); 6, Hatchel (41BW3) and Mitcheli (41BW4); 7, Hurricane Hill (41HP106); 8, 41RR181 and Little Mustang Creek; 9, 41TT670; 10, 41CS150; 11, Coker (41CS1); 12, 41TT372; 13, 41FK70; 14, Benson's Crossing; 15, Crabb (41TT650); 16, Harold Williams; 17, 41UR21; 18, Big Oaks; 19, Griffin Mound; 20, 41UR133; 21, 41UR8; 22, McKenzie; 23, Spoonbill; 24, 41RA65; 25, T. M. Moody; 26, 41WD518; 27, Yarbrough; 28, Charlie Crews; 29, Jamestown; 30, Carlisle; 31, Langford; 32, Bryan Hardy; 33, 41HS74; 34, Old Brown Place; 35, Oak Hill Village; 36, 41PN14; 37, Musgano (41RK19); 38, Pace McDonald; 39, 41CE42; 40, 41CE289; 41, George C. Davis; 42, 41CE290; 43, 41NA20; 44, Washington Square (41NA49); 45, Tyson (41SY92); 46, 41SA123; 47, 41SA89; 48, Knight's Bluff; 49, 41FK7; 50, Hudnall-Pirtle; 51, Gray's Pasture; 52. Redwine. Figure prepared by Robert Z. Selden Jr. 




Figure 78. Late Caddo period phases in East Texas and immediately surrounding areas. Figure prepared by Robert Z. Selden Jr. 


\section{CHAPTER 5, SUMMARY AND CONCLUSIONS}

The Paul Mitchell site (4IBW4) is an ancestral Caddo habitation site and cemetery in the larger ancestral and historic occupation of the Upper Nasoni Village on the Red River in Bowie County, in the northeastern corner of the present state of Texas. Extensive excavations were conducted at the site in the 1930s by both professional and avocational archaeologists, and in the 1940 s by an avocational archaeologist, but the findings from these investigations have never been fully analyzed or reported to date, although several bioarchaeological studies have been published concerning the Mitchell site human remains. For this monograph I have reexamined the records and collections from the various archaeological investigations in the cemetery at the Mitchell site, and the findings concerning the use of the site contribute to a fuller understanding of the history and prehistory of the Caddo peoples that lived at the Mitchell site and other settlements in the Rcd River valley of Northeast Texas.

The Paul Mitchell site is located in the McKinney Bayou floodplain about 2 miles from the current channel of the Red River to the north. The site is part of a large Upper Nasoni village believed to have extended several miles along the Red River, likely encompassing contemporaneous sites such as Eli Moores (41BW2), Hatchel (41BW3), Hargrove Moores (41BW39), and Horace Cabe (41BW 14). The Hatchel Mound is about $1.6 \mathrm{~km}$ north of the Mitchell site.

A number of excavations were conducted at the Paul Mitchell site in the 1930s and 1940s, beginning with investigations by The University of Texas (UT) in 1931 and 1932; the 1931 excavations were not productive as no cultural features were identified in the work along the levee bank. Work that followed in $1932,1935,1936,1938-1939$, and 1946 was almost totally focused on the identification and excavation of ancestral Caddo burials from a large cemetery along McKinney Bayou.

In September 1932 UT archaeologist A. T. Jackson and a crew explored an area 24-28 ft. west of the McKinney Bayou bank, in the Paul Mitchell family's back yard (Jackson 1932). This is some $150 \mathrm{~m}$ southeast from the later Works Progress Administration (WPA) excavations. During the work, four Caddo Indian burials (K-1 to K-4) were located in the Mitchell back yard, between depths of 53-91 cm below the ground surface. Only a single funerary offering accompanied these burials, a compound bowl with a high rim, and engraved scroll motifs on both the upper and lower rim panels that are stylistically reminiscent of both Barkman Engraved and certain Haley Engraved vessels.

W. H. Mathews, Jr., a local avocational archaeologist, excavated a total of 15 ancestral Caddo burials at the Mitchell site from February to April 1935, in an area just east of the later WPA excavations. Another six burials were excavated by unspecified others at the same time, but burial plans were obtained by Mathews, along with information on the associated funerary offerings. The burials were in an extended supine position, and appeared to be adults based on the size of the burial pits. In more than 80 percent of the burials, the deceased's head was facing to the north: two others were facing south. and two were facing either to the northeast or the northwest. One deceased Caddo individual (Burial 2) clearly had a cranially modified skull. The funerary offerings in the 21 burials included 59 ceramic vessels ( 2.8 vessels per burial), one ceramic elbow pipe, 40 conch shell beads ( 13.3 beads per burial among the three burials with shell beads), and one mussel shell that held a red clay pigment. The frequency of Barkman Engraved, Bowie Engraved, and Hatchel Engraved vessels in the burials suggests that many of the burials excavated by Mathews, Jr. were interments that date to after ca. A.D. 1400 to ca. A.D. 1500 or thereabouts, in the early to main part of the Late Caddo period. Other ceramic vessels of the types Friendship Fngraved, Haley Engraved, and Pease Brushed-lncised found in these burials likely datc to an earlier temporal interval, from ca. A.D. 1200-1400, during the Middle Caddo period, although Pease BrushedIncised vessels are commonly found in post-A.D. 1400 contexts in a number of sites and locales in East 
Texas. Later post-ca. A.D. 1500 Texarkana phase burials in the area excavated by Mathews, Jr. certainly include only Burial 12 with a Simms Engraved vessel (and a Late Caddo style elbow pipe). Other ceramics that may belong to this later period of interments include Karnack Brushed-Incised, Nash Neck Banded, and Moore Noded, but their occurrence in burials (Burials 15, 18, and 20) with Barkman Engraved and Hatchel Engraved suggests these vessels and burials may date instead to the earlier part of the Late Caddo period use of the cemetery. Earlier, pre-A.D. 1250 burials in the portions of the Mitchell site cemetery excavated by Mathews, Jr. may include two burials in the northern part of the cemetery. One of these burials had a plain bottle, a zoned incised-punctated jar, and a deep bowl with opposed curvilinear engraved lines and a suspension hole under the lip.

Glenn Martin and Harry Mathews (believed to be the same person as W. H. Mathews, Jr.) excavated two Caddo burials in 1936 in an unknown part of the cemetery at the Paul Mitchell site. Both burials (No. 1 and No. 2) were those of adults laid out in an extended supine position, with their heads at the northern end of the burial pits, facing to the south. Burial No. 1 had two ceramic vessels (a bowl with a scalloped rim and a small bottle) provided as funerary offerings. A single engraved vessel of unknown decorative style was in Burial No. 2, along with a marine shell gorget with an engraved cruciform style.

The WPA excavations at the Paul Mitchell site were extensive, and began on November 10, 1938. A. M. Woolsey was the archaeologist in charge and E. Glenn Martin was the project's time keeper. During the course of the project, which ended on January 10, 1939, 57 different ancestral Caddo burials were excavated in the cemetery, and habitation features and extensive midden deposits were also identified and excavated during the work. The WPA archaeologists did discover that the cemetery had also been rather thoroughly disturbed by pothunters in earlier years. Excavations were abandoned on January 10, 1939, hecause of rising water levels in Barkman Creek and McKinney Bayou. Burials and other features (i.e., midden deposits and house sites) were considered likely to also occur to the north and east of the excavation limits, and it was hoped that excavations could be resumed in the summer of 1939. However, the WPA investigations were limited at that time only to the Hatchel site.

Both children and adults had been laid in graves in an extended, supine position; rows of burials are not readily apparent. Most graves held one individual, but five burials had two individuals. Most of the deceased were laid in graves oriented southeast-northwest, with their heads in the southern part of the grave, and facing northwest; two burials faced west and one faced south. Funerary offerings were commonly placed with the deceased Caddo adults and children. These funerary offerings included ceramic vessels ( $n=110$ vessels; there were 96 vessels in 24 undisturbed burials, or 4.0 vessels per burial); clay pipes (nine pipes in eight burials); mussel shell valves (14 in 10 burials); one mussel shell hoe; a marine shell gorget in one burial; marine shell beads ( $n=142$ in nine different burials); bone hair pins $(n=3$ in two burials) and bone tools (one bone needle); bird and animal bones placed inside several vessels ( $\mathrm{n}=3$ burials); a possible animal bone necklace in one burial; turtle shells (in one burial); turtle shell rattles (two in one burial); bone $(n=5)$ and stone projectile points $(n=7)$; one celt; and a pigment stone.

The mean number of funerary offerings per adult male burial is 10.1 , about 28 percent more than is the case for the adult female burials. Adult male and female individuals at the site had the same amount of ceramic vessels, mussel shells, and conch shell beads placed as funerary offerings in graves. The two child burials had between them eight ceramic vessels (4.0 vessels per burial) and no other kinds of funerary offerings. The one adolescent burial in the UT investigations had only one ceramic vessel placed in its grave as a funerary offering. Funerary offerings that appear to be specific to the adult males at the Mitchell site are clay pipes, bone pins, arrow points, marine shell gorgets, celts, and turtle shell rattles; mussel shell hoes are specific to adult females. In general, the minor variability between child, adult female, and adult male burials in the Mitchell site cemetery with respect to the number and kind 
of funerary offerings suggest these ancestral Caddo individuals were not significantly different in social status or rank. It is not clear where the elite members of the Nasoni Caddo living at the Hatchel, Mitchell. and Moores sites were buried, but it does not appear, at least on the basis of burial treatment (in extended supinc positions in individual graves) and range of funerary offerings that individuals of elite status in the community were buried in the Mitchell site cemetery. The only possible exceptions to this possibility are two adult male burials that had conch shell gorgets (Burial 19 in the WPA excavations and Burial No. 2 in the 1936 excavations).

The Paul Mitchell site has both habitation features as well as a large cemetery. The principal habitation feature is a midden deposit on the northern and eastern sides of the cemetery, on the side of the cemetery nearest to McKinney Bayou. The principal midden deposit is situated in the northern portion of the area excavated by UT during the WPA investigations, and it is at least ca. $8-13 \mathrm{~m}$ in width and as much as ca. $55 \mathrm{~m}$ in length. 'The black midden deposit was encountered between $41-46 \mathrm{~cm}$ bs, and is buried hy alluvial deposits. It had ash, charcoal, pottery sherds, animal bones and mussel shells; mussel shell hoes were also common in the midden. A second and smaller midden deposit was exposed ca. $6 \mathrm{~m}$ south of the central part of the cemetery.

Other habitation fealures that were identified included a pit feature in the northeastern part of the cemetery, a hearth (Feature 1), atsh beds (Features 2 and 3), and Feature 4, another pit. The ash deposits appears to be part of burned structural debris because they rested on a zone of burned or baked red clay. and there were six post holes exposed as part of Feature 2 where they penetrated the red clay. The structural debris contained many ceramic sherds, chipped stone flakes, mussel shell fragments, and animal bones (including bird bones).

In March and September 1946, Pete Miroir, a well-known avocational archaeologist from Texarkana, and Babe Henson, investigated a large area $(80 \mathrm{x} 90 \mathrm{ft}$.) at the western end of the Mitchell site cemelery. During this work, three ancestral Caddo hurials were identified and excavated by Miroir. Funcrary offerings for these three individuals consisted of a celt, two ceramic ear spools, a long-stemmed Red River pipe, a cache of bone tools (a sharpened antler, two deer ulna flaking tool, and several deer long bones). as well as 13 ceramic vessels. They included Pease Brushed-Incised jars $(n=2)$; engraved bottles with concentric circle elements, likely of the Hatchel Engraved type $(n=2)$; Barkman Engraved carinated bowls ( $n=3$ ); Bowie Engraved carinated howls $(n=2)$; a Nash Neck Banded jar $(=1)$; a Glassell Engraved carinated bowl $(n=1)$; a Hatchel Engraved hottle $(n=1)$; and a Moore Noded bowl $(n=1)$. The stylistic character of these vessels indicate that these burials date to the early part of the Late Caddo period, from ca. A.D. $1400-1500$.

There are a total of 183 ceramic vessels from burial features excavated at the Mitchell site between 1932-1946. The following identified ceramic types are present in the Mitchell site assemblage, beginning with the utility wares: cf. Emory Punctated jars $(n=2)$; McKinney Plain jars $(n=5)$; Maydelle Incised jar $(n=3)$; Moore Noded bowls $(n=7)$; Nash Neck Banded jars $(n=19)$; and Pease Brushed-Incised jars ( $n=5)$. The predominant utility ware is Nash Neck Banded (40.3 percent), followed by Moore Noded ( 14.9 percent), McKinney Plain (10.6 percent), and Pease Brushed-Incised ( 10.6 percent). There are also two plain ware bottles and two plain bowls in the vessel assemblage. The plain wares account for only 3 percent of the mortuary vessels from the Mitchell site in the T'ARL sample.

The fine ware vessels from Mitchell are: Avery Engraved deep bowl $(n=1)$, carinated bowls $(n=1)$. and jar $(n=1)$; Barkman Engraved carinated bowls $(n=15)$ and deep bowls $(n=2)$; a Belcher Engraved bottle $(n=1)$; Bowie Engraved carinated bowls $(n=7)$; Friendship Engrated boltles $(n=2)$ and carinated bowls $(n=1)$; Haley Engraved bottles $(n=3)$ and deep bowls $(n=1)$; Hatchel Engraved bottles $(n=15)$; Hempstead 
Engraved bottle $(\mathrm{n}=1)$ and carinated bowl $(\mathrm{n}=2)$; Hickory Engraved bottles $(\mathrm{n}=5)$, including one Hickory Engraved, var. East bottle, and bowls $(\mathrm{n}=2)$; Means Engraved carinated bowl $(\mathrm{n}=1)$; Simms Engraved carinated bowl $(n=1)$; and Taylor Engraved bottles $(n=3)$ and jars $(n=1)$. The principal fine wares in the Mitchell site cemetery are Barkman Engraved (20 percent), Hatchel Engraved (17.4 percent), Bowie Engraved ( 8 percent), and Hickory Engraved ( 8 percent).

The earliest use of the cemetery by ancestral Caddo peoples is marked by ceramic fine ware vessels of the Friendship Engraved, Haley Engraved, Hempstead Engraved, Hickory Engraved, and Means Engraved types placed in burial features as funerary offerings. Utility wares include cf. Dunkin Incised jars as well as incised-punctated vessels, Pease Brushed-Incised jars, as well as incised, incised-punctatedappliqued, and punctated-appliqued vessels. A few jars have handles. There are also plain ware bowls, bottles, and jars included as funerary offerings in these ca. A.D. 1200-1400 burial features.

The remainder of the typologically identifiable fine wares are from later post-A.D. 1400 Texarkana phase burials in the Mitchell site cemetery. Early Texarkana phase (ca. A.D. 1400-1550) ceramic vessels certainly include vessels of the types Barkman Engraved, as well as Bowie Engraved, and Hatchel Engraved vessels and Avery Engraved compound bowls with flaring rims. The utility wares include the McKinney Plain, Moore Noded, Nash Neck Banded, Pease Brushed-Incised, and Foster Trailed-Incised types, as well as brushed-punctated jars and a punctated-appliqued jar with handles. The very latest Texarkana phase set of vessels (i.e., postdating ca. A.D. 1550-1600) in sites in the Upper Nasoni Caddo village include vessels of the following defined ceramic types: Simms Engraved, Hodges Engraved, Belcher Engraved, Keno Trailed, Taylor Engraved, Foster Trailed-Incised, Nash Neck Banded, and McKinney Plain. Such vessels have been found in burial features in the upper mound stages at the Hatchel temple mound, the late burial interments in Village Plot 2 at the Hatchel site, and several of the burials at the Eli Moores site (Perttula 2014a, 2014b). There are also a few such very late Texarkana phase burials in the cemetery at the Mitchell site, for example Burial 12 in the 1935 Mathews excavations and Burials 31 and 41 in the 1938 WPA excavations.

The decorated sherd assemblage from the Mitchell site $(\mathrm{n}=216)$ is almost exclusively grog-tempered, with only between 2.4-3.0 percent of the sherds at the Mitchell site having come from vessels tempered with bone. Most of the utility ware sherds from the Mitchell site have incised (44 percent of the utility ware rims, a number from Dunkin Incised vessels), incised-punctated (22 percent of the utility ware rims, including several with stylistic attributes of hoth Crockett Curvilinear Incised and Pennington Punctated-Incised vessels), and punctated (17 percent of the utility wares) decorative elements, but there are a wide assortment of other wet paste decorative elements; sherds with brushed elements (as the only decoration, or in combination with appliqued, incised, or punctated elements) comprise ca. 13 percent of the utility wares. Fine ware sherds include Handy Engraved, one of the principal fine wares in Middle Caddo period components along the Red River in Middle Caddo period (Haley phase) contexts. The high proportion of incised and incised-punctated sherds in the Mitchell site ceramic assemblage from habitation contexts is similar to the assemblage of decorated sherds recovered in Village Area II at the Hatchel site, where they are associated with 11 th-13th century A.D. calibrated radiocarbon dates. As discussed in Chapter 4, the one radiocarbon date from midden contexts at the Mitchell site has a 2 sigma calibrated age range of A.D. 1158-1262.

Approximately 28 percent of the engraved sherds in the Mitchell site ceramic assemblage from nonburial contexts are from bottles. Most feature curvilinear or opposed lines, along with open and excised pendant triangles; hatched or cross-hatched zones; tick marks; and appliqued nodes. A few bottle sherds are from Haley Engraved vessels, and another is from a Glassell Engraved bottle. Another bottle sherd has been identified from a Hatchel Engraved vessel, while design element configurations on several others are consistent with coming from Hatchel Engraved bottles. 
There are also later Texarkana phase ceramic sherds in the midden assemblage, including a Moore Noded bowl rim, brushed Karnack Brushed-Incised jar sherds, Emory Punctated-Incised jar sherds from burial fill, and Foster Trailed-Incised utility wares. Finc wares from the later use of the Mitchell site include sherds from Barkman Engraved, Glassell Engraved, and Simms Engraved vessels. along with sherds from Keno Trailed bowls and bottles.

Long-stemmed Red River pipes, var. Haley are found in Middle Caddo burials in the Mitchell cemetery, while ceramic elbow pipes are funerary offerings in several Texarkana phase burial features at the site. One ceramic spindle whorl was recovered in the midden deposits.

A 1932 surface collection from the Mitchell site has i number of chipped stone touls, including five biface preforms and eight dart points. The dart points are indicative of Late Archaic (ca. 5000)-2500 years B.P.) and Woodland (ca. 2500-I150 years B.P.) use; they are made from novaculite, various Red River cherts, and jasper.

A few chipped and ground stone tools and debris were recovered in the fill of three burials, including a sandstone grinding slab fragment, a brown jasper unifacial llake tool, a greenstone celt resharpening flake, brown jasper. novaculite, and quartzite cores, and cortical llakes of brown novaculite and gray chert.

A celt with a bifacial bit and a polished body was placed as a funerary offering in Burial 66: it is made from a Ouachita Mountians fine-grained greenstone. There are 35 small rounded chert and quarly pebbles in Burial 63 that are isssociated with a turtle shell rattle or rattles.

Excavations in the midden deposits on the east side of the cemetery recovered a number of antler tools. One is a perforated antler beam base; there are also three antler base fragments: another antler beam with two antler tines; and three antler tine distal fragments. There is also a near complete antler tine tool with a rounded end.

Other bone tools and fabricated objects include four deer ulna awls, two polished bone pins, and a burned bone bead in the midden deposits. A bone needle fragment was a funerary offering in Burial $6 \mathrm{~B}$. A distinctive bone tool in the assemblage is a fish bone needle $(n=3)$; the bone tools from Feature 2 are made from catfish spines.

There are 12 mussel shell hoes with single perforations and hoc fragments recovered from excavations in the midden deposits on the northwestern and east side of the cemetery. One other mussel shell hoe was a funerary offering in Burial 12 in the UT excavations, as well as in Burial 9 in the W. H. Mathews, Jr. collection. The Mitchell sile collection also has two unmodified mussel shell valves and valve fragments from three burials.

There are four different kinds of marine shell beads in the Mitchell site assemblage. The first are tubular or disk-shaped conch shell beads $(n=91)$ with a central perforation; these are from four burials. The second kind of marine shell bead is barrel-shaped conch columella beads ( $n=63$ from four burials) with a drilled opening at either end. The third kind of marine shell bead is oval-shaped Olivella beads $(\mathrm{n}=6)$, with openings at either end. The fourth kind are very small $(2.0-2.6 \mathrm{~mm}$ in diameter) disk-shaped Olivella beads $(n=5)$ from onc burial.

A marine shell gorget was one of the funerary offerings in Burial 19. The outer margins of the gorget have 15 petal-shaped or scalloped elements, two of which at the top have drilled perforations. Beginning at the inner edge of the petals to the center of the gorget (marked by a drilled circle), is a circular 
band filled with drilled dots; then an open circular band; and then a circle with a smaller central circle with the drilled circle. Radiating from the central circle are three excised curvilinear lines or volutes, and the design has a triskele structure. Very similar engraved gorgets have been recovered from $15^{\text {th }}$ and $16^{\text {th }}$ century contexts in Caddo burials on the Red River and in the mid-Ouachita River basin in Southwest Arkansas. Gorgets with this style of decoration have been classified as the Triskele style; these gorgets have a Nashville basin provenance in the Ohio River basin.

A second marine shell gorget was recovered from a burial excavated by Glenn Martin in 1936 at the Mitchell site. This gorget, $78.2 \times 80.1 \mathrm{~mm}$ in length and width, has two drilled holes $(3.8 \mathrm{~mm}$ in diameter) at the top, as well as a distinctive engraved design on the interior surface of the shell. It has two engraved circles (30.0 and $62.4 \mathrm{~mm}$ in diameter), the innermost with a cruciform design (cf. Brain and Phillips 1996:25) outlined by hatched triangular areas. At the center of the cruciform is a small excised dot. The outer circle has a series of hatched pendant triangles whose apexes point towards the inner engraved circle.

Certainly among the most distinctive artifacts found at the Mitchell site midden deposits are 12 perforated adult-sized human tecth: four molars and eight incisors. Another distinctive find among the funerary objects in the Mitchell site cemetery was 10 bones from the now extinct passenger pigeon in one of the ceramic vessels in Burial 52. Passenger pigeons were likely present in roosting areas in winter months along the Red River.

In summary, as the ceramic vessels and decorated sherds indicate, there were two principal periods of Caddo settlement and cemetery use at the Paul Mitchell site: during the Haley phase, and then later during the Texarkana phase. The Haley phase (ca. A.D. 1200-1400) component at the Mitchell site is marked by an extensive midden deposit and habitation features as well as a number of burials. The nearby Hatchel and Cabe (41BW14) sites have Haley phase village deposits and/or burials, but the mounds at both sites were constructed after ca. A.D. 1400 in the Texarkana phase. The ceramic set associated with Haley phase sites includes Dunkin Incised, East Incised, Friendship Engraved, Haley Complicated Incised, Haley Engraved, Handy Engraved, Hempstead Engraved, and Pease Brushed-Incised. The one radiocarbon date obtained from the Mitchell site (on charred organic residue scraped from a Dunkin Incised sherd) is from the Haley phase midden deposits. At 1 sigma, the most likely calibrated age range of the charred residue is A.D. 1169-1224 (0.62), while at 2 sigma, there is a 95 percent chance that the organic residue dates from A.D. 1158-1262; the median calibrated age is A.D. 1207.

The later use of the Mitchell site during the Texarkana phase dates after ca. A.D. 1400 to the latter part of the 17th century, based on calibrated radiocarbon dates from the nearby Eli Moores (41BW2) and Hatchel (41BW3) sites. Both sites have important Texarkana phase components with constructed mounds. The recovery of Texarkana phase ceramic sherds in the midden deposits indicates that the Mitchell site had habitation areas during this time, but the most distinctive part of the Texarkana phase component is the large cemetery at the southern end of the site. The Texarkana phase ceramic set includes Avery Engraved, Barkman Engraved, Bowie Engraved, Foster Trailed-Incised, Hatchel Engraved, Karnack Brushed-Incised, Keno Trailed (in the latest part of the phase), McKinney Plain, Moore Noded, Nash Neck Banded, Pease Brushed-Incised (in the earliest part of the phase), and Simms Engraved (in the latest part of the phase). Sites belonging to this phase are found on the Red River in Southwest Arkansas and Northeast Texas above the Great Bend of the Red and on the lower Sulphur River. The Hatchel site as well as the nearby Eli Moores (41BW2) and Cabe sites are major components of the Texarkana phase, with both constructed mounds and extensive village habitation deposits. All three sites, as well as the Mitchell site, may be part of an extensive Nasoni Caddo village that was visited by the Spanish in 1691 . 


\section{REFERENCES CITED}

Anderson, D. G.

2012 Monumentality in Eastern North America during the Mississippian Period. In Early New World Monumentality, edited by R. L. Burger and R. M. Rosenweig, pp. 78-108. University Press of Florida, Gainesville.

Blitz, J. H.

2010 New Perspectives in Mississippian Archaeology. Journal of Archaeological Research 18(1):1-39.

Bohannon, C.F.

1973 Excavations at the Mineral Springs Site, Howard County, Arkansas. Research Scries No. 5. Arkansas Archeological Survey, Fayetteville.

Brain, J. P. and P. Phillips

1996 Shell Gorgets: Styles of the Late Prehistoric and Protohistoric Southeast. Peabody Museum Press, Peabody Museum of Archacology and Ethnology, Harvard University, Cambridge.

Brown, J. A.

1996 The Spiro Ceremonial Center. The Archaeology of Arkansas Valley Caddoan Culture in Eastern Oklahoma. 2 Vols. Memoir No. 29. Museum of Anthropology, University of Michig , Ann Arbor.

2010 Cosmological Layouts of Secondary Burials as Political Instruments. In Mississippian Mortuary Practices: Beyond IFierarchy and the Representationist Perspective, edited by I.. P. Sullivan and R. C. Mainfort, Jr., pp. 30-53. University Press of Florida, Gainesville.

Butler, B. M. and P. D. Welch (editors)

2006 Leadership and Polity in Mississippian Society. Occasional Paper No. 33. Center for Archaeological Investigations, Southern Illinois University, Carbondale.

Cliff, M. B., S. M. Hunt, M. M. Green, R. S. Proctor, F. B. Largent, and W. J. Autin

1997 Geomorphological Investigations and Inventory of Cultural Resources along and near the Bowie County Levee, Bowie County, Texas: 1996. Miscellaneous Report of Investigations No. 139. Ge()Marine, Inc., Plano, Texas.

Creel, D. G.

1991 Burial Seriation and Occupational History at the Hatchel-Mitchell-Moores Complex, Bowie County, Texas. Paper presented at the $33^{\text {rl }}$ Caddo Conference, Nacogdoch $\mathrm{T}$ Texas.

1996 Hatchel-Milchell Site. In The New Handbook of Texas, Vol. 3, edited by R. Tyler, pp. 504-505. Texas State Historical Association, Austin.

Derrick, S. M. and D. Wilson

1997 Cranial Modeling as an Ethnic Marker among the Prehistoric Caddo. Bulletin of the Texas Archeological Society 68:139-146.

Early, A. M.

2000 The Caddos of the Trans-Mississippi South. In Indians of the Greater Southeast, edited by B. G. McEwan, pp. 122-141. University Press of Florida, Gainesvill:. 
2004 Prehistory of the Western Interior after 500 B.C. In Handbook of North American Indians, Southeast, Volume 14, edited by R. B. Fogelson, pp. 560-573. Smithsonian Institution, Washington.

Early, A. M. (editor)

1993 Caddoan Saltmakers in the Ouachita Valley: The Hardman Site. Research Series No. 43. Arkansas Archeological Survey, Fayetteville.

Etchieson, M.

1981 A Shell Gorget from the Kirkham Site. The Arkansas Archeologist 22:1-3.

Fields, R. C., E. F. Gadus, L. W. Klement, C. B. Bousman, and J. B. McLerran

1993 Excavations at the Tick, Spike, Johns Creek, and Peerless Bottoms Sites, Cooper Lake Project, Delta \& Hopkins Counties, Texas. Report of Investigations No. 91. Prewitt and Associates, Inc., Austin.

Girard, J. S.

2010 Caddo Communities of Northwest Louisiana. In Archaeology of Louisiana, edited by M. A. Rees, pp. 195-210. Louisiana State University Press, Baton Rouge.

Girard, J. S., T. K. Perttula, and M. B. Trubitt

2014 Caddo Connections: Cultural Interactions within and beyond the Caddo World. Rowman \& Littlefield, Lanham, Maryland.

Hoffman, M. P.

1967 Ceramic Pipe Style Chronology Along the Red River Drainage in Southwestern Arkansas. The Arkansas Archeologist 8(1):4-14.

Jackson, A. T.

1932 Exploration of a Cemetery on Paul Mitchell Farm in Bowie County, Texas. MS on file, Texas Archeological Research Laboratory, The University of Texas at Austin.

2003 Hatchel Site and Paul Mitchell Cemetery. Caddoan Archeology Journal 13 (No. 2):25-27.

Jackson, H. E., S. L. Scott, and F. F. Schambach

2012 At the House of the Priest: Faunal Remains from the Crenshaw Site (3MI6), Southwest Arkansas. In The Archaeology of the Caddo, edited by T. K. Perttula and C. P. Walker, pp. 47-85. University of Nebraska Press, Lincoln.

Laughlin, J. T.

1940 Laboratory Study of the Pottery, Potsherds and Artifacts from Site ET-30 Mound. Report on file at the Texas Archeological Research Laboratory, The University of Texas at Austin.

Lee, $\mathrm{C}$.

1997 Paleopathology of the Hatchel-Mitchell-Moores Sites, Bowie County, Texas. Bulletin of the Texas Archeological Society 68:16I-177.

Lippert, D. T.

1997 A Combination of Perspectives on Caddo Indian Health. Ph.D. dissertation, Department of Anthropology, The University of Texas at Austin. 
Kelley, D. B. (editor)

1997 Two Caddoan Farmsteads in the Red River Valley. Research Series No. 51. Arkansas Archeologici Survey, Fayetteville.

Kelly, L. S.

2012 Faunal Remains from Mound S, Toltec Mounds Site. In Toltec Mounds: Archeology of the Mound-and-Plaza Complex, by M. A. Rolingson, pp. 123-151 . Research Series No. 65. Arkans Archeological Survey, Fayetteville.

Martin, G.

1936 Supplementary Field Notes by Glenn Martin, Paul Mitchell Place. Bowie County, Texas, Sunday, November 22, 1936. MS on file, Texas Archeological Research Laboratory, The 1 it iversity of Texas at Austin.

Mathews, W. H., Jr.

1935 Catalog of Prehistoric Indian Pottery Excavated by Wm. H. Mathews, Jr., Texarkana, Texas. ^ on file, Texas Archeological Research I aboratory, The University of Texas at Austin.

Miroir, P.

1946 Cemetery on the Runnels Farm. MS on file, Texas Archeological Researc. Laboratory, The University of Texas at Austin.

O'Brien, M. J. and R. L. L.yman

1999 Seriation, Stratigraphy, and Index Fossils: The Backbone of Archaeological Dating. Kluwer Academic/Plenum Publishers, New York.

Parmalee, P. W.

1957 Vertebrate remains from the Cahokia site, Illinois. Transactions of the Ill $l$ s Academy of Sciences $50: 235-242$.

Perino, G.

1981 Archeological Investigations at the Roden Site (MC-215), McCirtain County, Oklahoma. Potsherd Press No. 1. Museum of the Red River, Idabel.

Perttula, T. K.

1992 "The Caddo Nation": Archaeological and Ethnohistoric Perspectives. University of Texas Press, Austin.

2005 1938-1939 WPA Excavations at the Hatchel Site (41BW3) on the Red River in Bowie County, Texas. Southeastern Archaeology 24(2):180-198.

2008 The Archeology of the Roitsch Site (41RR 16), an Early to Historic Caddo Period Village on the Red River in Northeast Texas. In Collected Papers from Past Texas Archeological Society Summer Field Schools, edited by T. K. Perttula, pp. 313-628. Special Publication No. 5. Texas Archeological Society, San Antonio.

2014a Ar haeological Studies of the Hatchel Site (41BW3) on the Red River in B. vie ( inty, Texas. Special Publication No. 23. Friends of Northeast Texas Archaeology, Austin and Pittsburg. 
2014b The Eli Moores Site, a 17th to Early 18th Century Caddo Site on the Red River, Bowie County, Texas. Special Publication No. 31. Friends of Northeast Texas Archaeology, Austin and Pittsburg, in press

Perttula, T. K. and B. Nelson

2003 Archeological Investigations of Village Areas at the Hatchel Site (41BW3), Bowie County, Texas. Report of Investigations No. 58. Archeological \& Environmental Consultants, LLC, Austin.

Perttula, T. K., J. E. Bruseth, N. A. Kenmotsu, and W. A. Martin

1995 Archeological Testing at the Cabe Mounds (41BW14), Bowie County, Texas. Cultural Resource Management Report 8. Department of Antiquities Protection, Texas Historical Commission, Austin.

Perttula, T. K., R. Z. Selden, Jr., and D. Wilson

2014 Corn is Life: Temporal Trends in the Use of Corn (Zea mays) by Caddo Peoples from Radiocarbondated Samples and Stable Isotope Analyses. Bulletin of the Texas Archeological Society 85, in press.

Perttula, T. K., C. P. Walker, and T. C. Schultz

2008 A Revolution in Caddo Archaeology: The Remote Sensing and Archaeological View from the Hill Farm Site (41BW169) in Bowie County, Texas. Southeastern Archaeology 27(1):93-107.

Samuelsen, J. R.

2014 AMS and Radiocarbon Dating of the Crensbaw Site (3MI6). The Arkansas Archeologist 52:17-35.

Skinner, S. A., R. K. Harris, and K. M. Anderson (editors)

1969 Archaeological Investigations at the Sam Kaufman Site, Red River County, Texas. Contributions in Anthropology No. 5. Department of Anthropology, Southern Methodist University, Dallas.

Sorrow, W. M.

1968 A Brief Analysis of the Complete Vessels from the Hatchel and Mitchell Sites. MS on file, Texas Archeological Research Laboratory, The University of Texas at Austin.

Suhm, D. A. and E. B. Jelks (editors)

1962 Handbook of Texas Archeology: Type Descriptions. Special Publication No. 1, Texas Archeological Society, and Bulletin No. 4, Texas Memorial Museum, Austin. Reprinted in 2009, Gustav's Library, Davenport, Iowa.

Sundermeyer, S. A., J. T. Penman, and T. K. Perttula

2008 Integrated Cultural Resources Investigations for the Bowie County Levee Realignment Project, Bowie County, Texas and Little River County, Arkansas. Miscellaneous Reports, Report of Investigations No. 29. LopezGarcia Group, Dallas.

Thurmond, J. P., and U. Kleinschmidt

1979 Report on the Fall 1978 Investigations at the George C. Davis Site, Caddoan Mounds State Historic Site, Cherokee County, Texas. Texas Archeological Research Laboratory, The University of Texas at Austin.

Wilson, D.

1997 Dental Paleopathology in the Sanders (41LR2) and Mitchell (4IBW4) Populations from the Red River Valley, Northeast Texas. Bulletin of the Texas Archeological Society 68:147-159. 
Woolsey, A. M. and E. G. Martin

1939 Field Notes WPA Archaeological Project Sponsored by Anthropology Department, The University of Texas: Site ET-547, Paul Mitchell Place, 11 1/2 miles N.W. Texarkana, Bowic County, Texas. MS on file, Texas Archeological Research Laboratory, The University of Texas at Austin. 